\title{
Handlingsrom for profesjonalisert velferd
}

Kommunale tjenester for helse, omsorg og barnevern

Bente Lilljan Lind Kassah, Hilde Nordahl-Pedersen og Wivi-Ann Tingvoll (red.)

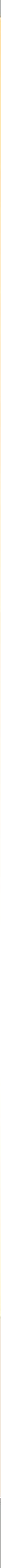


Handlingsrom for profesjonalisert velferd 

Bente Lilljan Lind Kassah, Hilde Nordahl-Pedersen og Wivi-Ann Tingvoll (red.)

\section{Handlingsrom for profesjonalisert velferd}

KOMMUNALE TJENESTER FOR HELSE, OMSORG OG BARNEVERN 
(C) 2021 Bente Lilljan Lind Kassah, Hilde Nordahl-Pedersen, Wivi-Ann Tingvoll, Grethe M. Borgerød, Anne Svelstad Evju, Sven-Tore Dreyer Fredriksen, Lena Wiklund Gustin, Mona Lahm Høgbakk, Katrine Høgmo, Kwesi Alexander Kassah, Sari Lindgren, Linda M. Løvdal, Randi Nymo, Bodil S. Olsvik, Karin Ravn Pedersen, Margrethe Amalie Tresselt og Synnøve Vestly.

Dette verket omfattes av bestemmelsene i Lov om opphavsretten til åndsverk m.v. av 1961. Verket utgis Open Access under betingelsene i Creative Commons-lisensen CC-BY 4.0 (http://creativecommons.org/licenses/by/4.o/). Denne tillater tredjepart å kopiere, distribuere og spre verket i hvilket som helst medium eller format, og å remixe, endre, og bygge videre på materialet til et hvilket som helst formål, inkludert kommersielle, under betingelse av at korrekt kreditering og en lenke til lisensen er oppgitt, og at man indikerer om endringer er blitt gjort. Tredjepart kan gjøre dette på enhver rimelig måte, men uten at det kan forstås slik at lisensgiver bifaller tredjepart eller tredjeparts bruk av verket.

Boka er utgitt med støtte fra UiT Norges arktiske universitet.

ISBN trykt bok: 978-82-02-70671-5

ISBN PDF: 978-82-02-65230-2

ISBN EPUB: 978-82-02-70666-1

ISBN HTML: 978-82-02-70667-8

ISBN XML: 978-82-02-70668-5

DOI: https://doi.org/10.23865/noasp.114

Dette er en fagfellevurdert antologi, kapitlene 2-11 er vitenskapelige bidrag.

Omslagsdesign: Cappelen Damm AS

Omslagsbilde: Gettyimages/A-Digit

Cappelen Damm Akademisk/NOASP

noasp@cappelendamm.no 


\section{Innhold}

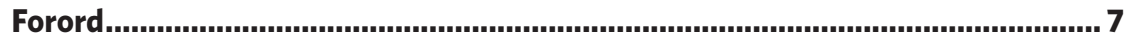

Kapittel 1 Antologiens sentrale begreper og perspektiver.................................9 Bente Lilljan Lind Kassah, Hilde Nordahl-Pedersen og Wivi-Ann Tingvoll

Kapittel 2 Utfordringer i tverrfaglig samarbeid. Kommunal helse- og omsorgstjeneste samt kommunalt barnevern................. 27 Sven-Tore Dreyer Fredriksen, Bente Lilljan Lind Kassah og Wivi-Ann Tingvoll

Kapittel 3 Sjuksköterskans kärnkompetenser. .47 Lena Wiklund Gustin

Kapittel 4 Kompetansebegrepets uklarhet i møte med barnevernets komplekse handlingsrom.

Margrethe Amalie Tresselt og Grethe M. Borgerød

Kapittel 5 Ledelse av profesjonalisert velferd i et paradoksteoretisk perspektiv 105 Bodil S. Olsvik

Kapittel 6 Utøvelse av ledelse i kommunale sykehjem handlingsrommets betydning 131 Bente Lilljan Lind Kassah, Hilde Nordahl-Pedersen og Wivi-Ann Tingvoll

Kapittel 7 Utøvelse av kunnskapsbasert praksis i sykehjem 155 Karin Ravn Pedersen og Wivi-Ann Tingvoll

Kapittel 8 Å skape handlingsrom for pasientsikkerhet i sykehjem. Sykepleieres erfaringer med å delta i simulering in situ på sykehjem . 177

Sari Lindgren, Mona Lahm Høgbakk, Anne Svelstad Evju og Lena Wiklund Gustin 
Kapittel 9 Muligheter og begrensninger i sykepleierens handlingsrom når sykehjemspasientens sykdomstilstand forverrer seg 199

Synnøve Vestly og Linda M. Løvdal

Kapittel 10 Kulturell trygghet for den samiske pasienten i møter med helsevesenet

Randi Inger Johanne Nymo

Kapittel 11 Kunnskap om barns kollektive ansvarserfaringer og implikasjoner for tjenesteutøvelse $\mathbf{i}$ barnevernet .243

Katrine Høgmo, Kwesi Alexander Kassah og Bente Lilljan Lind Kassah

Forfatteromtaler. .263 


\section{Forord}

Denne boken er et resultat av samarbeid mellom ansatte ved UiT Norges arktiske universitet. Forfatterne er tilknyttet Institutt for helse- og omsorgsfag ved sykepleieutdanningen i Harstad og Narvik, barnevernspedagogutdanningen i Harstad ved Institutt for barnevern og sosialt arbeid samt Handelshøyskolen i Harstad. Boken er preget av en flerfaglig tilnærming til de ulike temaene som belyses. Sett i forhold til myndigheters ønske om å styrke tverrfaglig samarbeid, både i kommunal helse- og omsorgstjeneste, samt i kommunalt barnevern, er antologiens flerfaglige tilnærming viktig for både utdanning og praksisfelt.

Redaktørene takker forfatterne for innsatsen, og for at de ønsker å dele sin kunnskap om utfordringer i handlingsrommet for profesjonalisert velferd.

Vi takker også UiT Norges arktiske universitet for forskningstid og tilrettelegging i forsknings- og skriveprosessene. Til slutt takker vi gode kollegaer som har bidratt med konstruktive innspill underveis i arbeidet med boken.

Harstad/Narvik, 2020

Bente Lilljan Lind Kassah, Hilde Nordahl-Pedersen og Wivi-Ann Tingvoll (red.) 



\title{
KAPITTEL 1
}

\section{Antologiens sentrale begreper og perspektiver}

\author{
Bente Lilljan Lind Kassah, Hilde Nordahl-Pedersen og \\ Wivi-Ann Tingvoll
}

UiT Norges arktiske universitet

\begin{abstract}
This chapter provides an overview of key concepts and theoretical perspectives used in the anthology and points out fundamental challenges in the practice of professional welfare. 'Competence' and 'knowledge' often have different meanings, and there is a need for increased awareness of the understanding of these concepts. This chapter highlights how the managerial discretion, learning, system blindness, power executing and paradoxes may cause tensions and how these in turn may inhibit the realization of required changes. Internal or external job recruitment may have an impact on managers' freedom to act. To raise the quality and competence within the professional welfare services, it is necessary to be aware of the unique and multi-faceted challenges in the field.
\end{abstract}

Keywords: managerial discretion, leadership, organization, competence, core competence, knowledge

\section{Introduksjon}

\section{Ivaretakelse av samfunnsoppdraget - ulike utfordringer}

Denne boken retter søkelyset mot utfordringer knyttet til ivaretakelse av samfunnsoppdraget i de kommunale helse-, omsorg- og barneverntjenestene. Hensikten er å gi leseren innblikk i tjenesteutøvernes handlingsrom når de søker å benytte sin kompetanse i tjenesteutøvelsen. I dette

Forfatterne er likeverdige bidragsytere

Sitering av denne artikkelen: Kassah, B. L. L., Nordahl-Pedersen, H. \& Tingvoll, W.-A. (2020). Antologiens sentrale begreper og perspektiver. I B. L. L. Kassah, H. Nordahl-Pedersen \& W.-A. Tingvoll (Red.), Handlingsrom for profesjonalisert velferd: Kommunale tjenester for helse, omsorg og barnevern (Kap. 1, s. 9-25). Oslo: Cappelen Damm Akademisk. https://doi.org/10.23865/noasp.114.ch1 Lisens: CC-BY 4.0. 
kapitlet vil vi gjøre rede for begreper som kunnskap, kompetanse, kjernekompetanse, tverrfaglig samarbeid, ledelse og organisasjon. Begrepene er viktige komponenter i det vi kaller tjenesteutøvernes handlingsrom. Sammen utgjør disse begrepene en felles ramme for antologien.

En av flere utfordringer tjenesteutøvere møter når de skal ivareta sitt samfunnsoppdrag, er den omfattende etterspørselen som finnes etter de fleste offentlige hjelpeordninger. Her kan det virke som om velferdssystemet rammes av en forventningskrise (Stamsø, 2017). Politiske føringer og prioriteringer som skal møte utfordringene i kommunalt barnevern og helse- og omsorgstjenester, bidrar også til nye arbeidsoppgaver og $ø \mathrm{kt}$ ansvar innenfor disse kommunale tjenestene (Helse- og omsorgsdepartementet, 2009, 2013, 2015; Barne-, ungdoms- og familiedirektoratet [Bufdir], 2019b).

Barnevernets samfunnsoppdrag og mandat er forankret i barnevernloven (2019), der det framkommer følgende:

[Barnevernet] skal sikre at barn og unge som lever under forhold som kan skade deres helse og utvikling, får nødvendig hjelp, omsorg og beskyttelse til rett tid. Loven skal bidra til at barn og unge møtes med trygghet, kjærlighet og forståelse og at alle barn og unge får gode og trygge oppvekstvilkår.

Barnevernsreformen (Barne- og likestillingsdepartementet, 2017) som iverksettes fra 2020, gir kommunene økt handlingsrom for å prioritere bruk av ressurser samt innrette tjenestetilbudet ut fra lokale behov. I 2015 var det 53439 barn som hadde tiltak fra barnevernet (Stamsø, 2017). Utviklingen er kjennetegnet av stadig flere meldte barnevernsaker og $ø$ kning i antallet barn som mottar hjelpetiltak (Barnevernpanelet, 2011; Stamsø, 2017). Barnevernet opplever samtidig økt kompleksitet i saksbehandlingen og har behov for et bredt tilfang av kompetanse (Barnevernpanelet, 2011).

Lignende utfordringer preger også de kommunale sykepleietjenestene, der man opplever økt arbeidsbelastning over tid og økt tempo i arbeidet. Samtidig får tjenestene flere pasienter med komplekse og sammensatte lidelser. Karoliussen (2015, s. 3) sier at utviklingen har bidratt til at, «kompleksiteten i sykepleien som burde være tilgjengelig for pasientene er redusert, noen ganger til det kritisk minimale». Dette er betenkelig 
når helse- og omsorgstjenestens samfunnsoppdrag er å sikre at pasienter får forsvarlige tjenester, og at faglige verdier ivaretas (helse- og omsorgstjenesteloven, 2011). De omtalte endringene i arbeidshverdagen påvirker ansattes handlingsrom når de søker å benytte sin kompetanse for å ivareta samfunnsoppdraget (Tingvoll, Kassah \& Kassah, 2014; Kassah, Tønnessen \& Tingvoll, 2014).

Denne korte situasjonsbeskrivelsen viser at det er flere fellestrekk i utfordringene kommunalt barnevern og helse- og omsorgstjenester står overfor. Utfordringene kan blant annet knyttes til kommunalt eierskap, mangelfull kompetanse i tjenestene, økte krav om tjenesteproduksjon, tverrfaglig samarbeid samt stadig mer kompleks tjenesteutøvelse. I denne antologien knyttes derfor utfordringene sammen og belyses gjennom de ulike kapitlene. Det forventes også brukervennlige og innovative tjenester, noe som betinger at tjenesteutøverne kan forstå og tolke sine omgivelser for å være i stand til å utvikle nye løsninger (Ringholm \& Holmen, 2019).

\section{Kunnskap og kompetanse}

Begrepene kunnskap og kompetanse er viktige for å belyse noen sentrale utfordringer i tjenestene. Dette fordi kunnskapstilfanget og kompetansen i tjenestene har betydning for tjenesteutøvelsens kvalitet og effektivitet. Rent kunnskapsteoretisk er det utfordrende å avgrense de mangefasetterte begrepene kunnskap og kompetanse. Det gis her en kort introduksjon til begrepene, og til hvordan de benyttes i antologiens ulike bidrag. Begrepet kunnskap kan klassifiseres og operasjonaliseres på ulike måter. Innenfor gresk klassisk tradisjon blir deklarativ kunnskap forstått som den kunnskap en person kunne fortelle at han var i besittelse av. Begrepet techne, eller ferdighet, betegner at en person kunne bruke kunnskapen til å gjøre praktiske oppgaver. Det tredje nivået i den greske klassiske tradisjonen omtales som fronesis, som betegner at personen har fått innsikt og visdom. Denne kunnskapsforståelsen kan gjenfinnes i dagens kunnskapsbegreper og meningsinnhold. I denne antologien tas det utgangspunkt i Lai (2013) sine begreper om kunnskap. Deklarativ kunnskap omfatter informasjons- og faktakunnskap, og kausal kunnskap betegner 
årsakssammenhenger og relasjoner. Prosedyrisk kunnskap handler om praktiske, konkrete prosesser og metoder (Lai, 2013). Disse kunnskapsformene er preget av å være eksplisitte, det vil si at kunnskapen kan verbaliseres og videreformidles (Polanyi, 1983). Eksplisitt kunnskap settes ofte i system gjennom strukturer, rutiner og prosedyrer (Jacobsen \& Thorsvik, 2019) for å styre tjenesteutøvelsen.

Kunnskap kan imidlertid også ha en taus dimensjon som kan være viktig for tjenesteutøvelse, både i kommunal helse- og omsorgstjeneste og i barnevern. Taus kunnskap lar seg vanskelig verbalisere, da kunnskapen ofte er internalisert (Polanyi, 1983). Det vil si at kunnskapen er blitt en del av den enkelte tjenesteutøvers virkelighetsforståelse og virker styrende for blant annet problemforståelse, oppgaveløsning og samhandling. Taus kunnskap er med andre ord ikke deklarativ, men er en kunnskap som er blitt til en del av et menneskets forståelseshorisont, og som finner gjenklang i den greske kunnskapsforståelsen fronesis. Taus kunnskap kan være handlingsorientert og videreføres ofte gjennom observasjon og handling. Denne kunnskapsformen er sannsynligvis en viktig dimensjon ved for eksempel skjønnsutøvelse i kommunalt barnevern og innenfor helse- og omsorgstjenester. Det kan imidlertid være utfordrende å ta i bruk taus kunnskap i tjenesteutøvelsen. Dette fordi kunnskapen blir vanskelig tilgjengelig med mindre aktører deler den tause kunnskapen gjennom felles handling.

Kompetanse henger tett sammen med kunnskap, og kompetanse innebærer at en person er kompetent til å utføre oppgaver. Ifølge Lai (2013) kan kompetanse defineres som et potensial som er sammensatt av fire komponenter. Disse komponentene er samlede kunnskaper, ferdigheter, evner og holdninger som må være til stede for å utføre oppgaver i tråd med definerte krav og mål. Ferdigheter er en viktig komponent i kompetansebegrepet og kan operasjonaliseres på ulike måter, alt etter hvilke dimensjoner ved begrepet som vektlegges i ulike kontekster. Den handlingsorienterte forståelsen av begrepet er overordnet, og Imsen (2017) betrakter ferdigheter som handlingsorientert og handling krever trening. Lai (2013) forstår for eksempel ferdigheter som evnen til å utføre komplekse adferdsmønstre for å nå et definert mål. Ferdigheter kan utvikles gjennom både kunnskapslæring og praktisk øvelse samt observasjon. 
Taus kunnskap, som er en del av en persons samlede kunnskap, kan slik deles. Den enkelte tjenesteutøverens mulighet for å utvikle ferdigheter blir påvirket av både kunnskaper, evner og holdninger (Lai, 2013).

Holdninger er et komplekst fenomen og etableres gjennom primærog sekundærsosialisering der viktige verdier formidles og internaliseres. Holdninger kan slik betraktes som en konkretisering av verdier (Martinussen, 1991). Holdninger anses som satt sammen av tre komponenter: En kognitiv komponent som reflekterer virkelighetsoppfatningen som en persons holdninger bygger på, en affektiv komponent som omhandler følelser og standpunkter, og en atferdsmessig komponent som sier noe om forholdet mellom holdning og handling. Visse holdninger fører til visse handlinger (Schiefloe, 2019). Ifølge Martinussen (1991) er holdninger som et arkivsystem som gir den enkelte psykisk trygghet. Holdninger bidrar samtidig til at oppfatninger og vurderinger framkommer som stabile og konsistente. Den sosiologiske forståelsen av holdninger som er kort skissert her, kommer også til uttrykk i forståelsene av begrepet holdninger som benyttes i denne boken. Lai (2013) gir uttrykk for at holdninger formidler noe om det potensialet en tjenesteutøver har for å utføre aktuelle oppgaver, og for å nå de målene som er etablert $\mathrm{i}$ organisasjonen. Det å skulle vurdere om en tjenesteutøver har det potensialet som skal til for å ivareta ulike oppgaver, kan være utfordrende. Dette fordi tjenesteutøverens verdier og følelser (Imsen, 2017) kan påvirke hvordan den enkelte forstår både arbeidsoppgaver og målformuleringer. En tjenesteyters potensial for å ivareta ulike arbeidsoppgaver kan også bli begrenset eller styrket, alt avhengig av hvilke normer som styrer samhandlingen mellom ansatte i tjenesteutøvelsen.

Holdningsdimensjonen i den enkeltes kompetanse kan sies å være spesielt viktig innenfor kommunale barnevern- og helse- og omsorgstjenester, der kunnskap om relasjoner har en sentral plass. Tjenesteutøveres verdier og holdninger utfordres stadig mer i vårt multikulturelle samfunn, spesielt når tjenesteutøverne konfronteres med barneoppdragelse og sykdomsregimer som kan avvike fra norske fortolkninger av hvilke verdier som er viktige å ivareta i tjenesteutøvelsen. Dette har for eksempel kommet tydelig fram i forbindelse med barnevernssaker som har vært til behandling i den internasjonale menneskerettsdomstolen (Schönfelder \& Holmgaard, 2019). 
Evner er også en sentral dimensjon i Lais (2013) forståelse av kompetanse. Ifølge Lai (2013, s. 50) er «evner av en så stabil og grunnleggende karakter at de ikke i vesentlig grad lar seg påvirke gjennom tilegnelse av nye kunnskaper, ferdigheter eller holdninger». Denne forståelsen av evner kan gjenfinnes i Dweck (2002) sin forskning om tankesett. Dweck er sentral innenfor ledelsesforskning, og hun belyser to tankesett for å betegne hvordan evner kan forstås i en organisatorisk kontekst. Det første tankesettet er preget av at tjenesteutøvere kan forbedre kvaliteter, egenskaper og evner. Det andre tankesettet innebærer at evner kan være medfødt, og at mulighetene for å endre evner er begrenset. Lai (2013) kan muligens plasseres innenfor dette sist omtalte tankesettet når hun gjør rede for evnenes betydning i forbindelse med begrepet kompetanse. Bokens bidrag preges av Dwecks første tankesett, det vil si at evner kan forbedres gjennom for eksempel tilegnelse av kunnskap og erfaring.

I Lais (2013) definisjon av kompetanse kan det gjenkjennes en rasjonalistisk tilnærming slik den framstilles av Sandberg (2000), som retter søkelyset mot kunnskap, ferdigheter og personlighetstrekk for å løse gitte oppgaver. Sandbergs (200o) tolkning av kompetanse som en rasjonalistisk og fortolkende tilnærming er interessant innenfor kommunalt barnevern og helse- og omsorgstjenester, som preges av omfattende kompetanseutfordringer. Sandbergs (200o) fortolkende perspektiv er også til stede i den kompetanseforståelsen som ligger til grunn for bokens bidrag. En fortolkende tilnærming til kompetanse bygger på en antagelse om at det er en sammenheng mellom en tjenesteutøvers kompetanse og den meningen en tjenesteutøver tillegger arbeidsoppgavene. To av denne bokens kapitler belyser spesielt hvordan tjenesteutøveres kompetanse har betydning for muligheter og begrensninger i tjenesteutøvelsen. Kapittel 10 «Kulturell trygghet for den samiske pasienten i møter med helsevesenet» er et empirisk bidrag der Nymo diskuterer utfordringer knyttet til kompetanse om kulturforskjeller når samiske pasienter møter norsk helsevesen. Utfordringer knyttet til kultur og kompetanse framkommer også i kapittel 11 «Kunnskap om barns kollektive ansvarserfaringer og implikasjoner for tjenesteutøvelse i barnevernet», der Høgmo, Kassah og Kassah belyser hvordan økt kunnskap om krysskulturelle barns kollektive ansvarserfaringer kan ha betydning for kommunalt barnevernansatte som 
jobber for å sikre barnets beste. Data er basert på litteratur om kollektive ansvarserfaringer hos barn utenfor Europa og blant krysskulturelle barn i Norge.

Det er vanskelig å diskutere bruk av kompetanse i en organisatorisk kontekst som barnevern og helse- og omsorgstjeneste uten å ha et bevisst forhold til begrepet makt og maktutøvelse. Det sies ofte at kompetanse gir makt, men ifølge Lai (2013) må personer rundt den som innehar kompetansen, anerkjenne personens kompetanse. Først da gir kompetanse makt. Denne relasjonelle forståelsen av makt er tett knyttet til en fortolkende tilnærming til kompetansebegrepet, der det legges vekt på at tjenesteutøveres kompetanse må betraktes i en kontekst. Utfordringene knyttet til fortolkning av kompetansebegrepet kommer tydelig fram i kapittel 4, «Kompetansebegrepets uklarhet i møte med barnevernets komplekse handlingsrom». Her viser Tresselt og Borgerød gjennom tekstanalyse av relevante offentlige dokumenter at begrepet kompetanse, slik det benyttes i barnevernfeltet, mangler en klar definisjon. Forfatterne løfter fram at et uklart definert kompetansebegrep kan ha betydning for tjenesteutøvelsen når samfunnsoppdraget skal ivaretas. Dette fordi tjenesteutøvere i ulike organisatoriske kontekster kan fortolke kompetansebegrepet ulikt.

Kompetanse omfatter også begrepet kjernekompetanse, et begrep som opprinnelig kommer fra teorier om forretnings- og foretaksstrategi. Begrepet blir imidlertid stadig mer brukt innenfor teori om kompetanse og kompetanseutvikling i andre kontekster. Begrepet benyttes her fordi det innbyr til klare definisjoner av en organisasjons unike kompetanse for å utføre organisasjonens arbeidsoppgaver. Både innenfor barnevern og helse- og omsorgstjenesten er det behov for å definere og avklare hvilket kompetansetilfang tjenestene skal ha i framtiden. Kjernekompetanse kan forstås som en unik kompetanse som skiller ulike yrkesgrupper fra hverandre (Lai, 2013), og som bidrar til at for eksempel sykepleiere og barnevernansatte kan ivareta sitt fagområde på en måte som er vanskelig å etterligne. Organisasjonens kjernekompetanse er et resultat av en kollektiv læringsprosess og kan være vanskelig å identifisere og utfordrende å endre (Volberda \& Elfring, 2001). Kjernekompetanse er utfordrende å identifisere fordi kollektive læringsprosesser kan bidra til at kunnskapen 
blir tatt for gitt. Kunnskapen verbaliseres sjelden, men kan dog være et bærende element i utrednings- og beslutningsprosesser. Kjernekompetansens forankring i organisasjonen tyder på at den er legitimert i organisasjonen (Nonaka \& Takeuchi, 1995). Det vil si at kunnskapen blir forstått, godtatt og ansett av ansatte som viktig for oppgaveløsingen i organisasjonen. Ansatte sosialiseres inn i rutiner og tankemønstre som bygger på den legitimerte kunnskapen som etter hvert blir et felles minne. Disse ligger til grunn for ansattes forståelse av hvordan ulike arbeidsoppgaver skal ivaretas.

Kjernekompetanse er ikke et etablert begrep innenfor kommunalt barnevern eller helse- og omsorgstjeneste. Trana (2013) aktualiserer imidlertid begrepet når hun løfter fram kjærlighet som en mulig kjernekompetanse i barneverntjenesten. En avklaring av hva som er tjenestenes kjernekompetanse, kan være viktig fordi tjenestene sliter med kompetansemangel og kompetansesammensetning for å ivareta sine arbeidsoppgaver. Samtidig benyttes mange begreper for å beskrive kompetansebehovet i tjenestene. Bruk av flere kompetansebegreper med ulikt meningsinnhold i offentlige dokumenter og annen litteratur kan skyldes en uklar forståelse av hvilken kompetanse som best kan ivareta barneverntjenestens samfunnsoppdrag. Wiklund Gustins teoretiske bidrag «Kjernekompetanser i sykepleie» i kapittel 3 kan gi viktige innspill til diskusjonen om sykepleieres kjernekompetanse. Forfatteren presenterer seks kjernekompetanser som benyttes innenfor sykepleie i Sverige. Det reflekteres samtidig over sykepleie som en profesjon med et teoretisk fundament i omsorgsvitenskap. Begrepet kjernekompetanse belyses også i kapittel 7, «Utøvelse av kunnskapsbasert praksis i sykehjem». I denne studien, som bygger på data fra et studentprosjekt i sykepleieutdanningen, tydeliggjør Pedersen og Tingvoll kunnskapsbasert praksis som en mulig kjernekompetanse i sykepleien.

\section{Handlingsrom}

Begrepet handlingsrom er gitt en sentral plass i denne boken og trenger en nærmere avklaring. Handlingsrom kan enkelt forklart betraktes som et mulighetsrom for handling. Dette mulighetsrommet framkommer 
når ledere og ansatte skal gjøre sine valg innenfor de begrensninger, krav og muligheter som organisasjonsstruktur og samfunnsoppdrag gir. Begrensninger $\mathrm{i}$ et handlingsrom skapes av økonomi, avtaleverk, lover, politikk og lignende. Krav som legger føringer på handlingsrommet, kan for eksempel være ulike mål, tidsfrister samt forventninger fra omgivelsene og en selv (Espedal \& Kvitastein, 2012). Handlingsrom kan med andre ord betraktes som de muligheter og begrensninger ledere og ansatte opplever i sin arbeidshverdag. Handlingsrommet er komplekst samtidig som det er i stadig endring (Schönfelder, Andersen \& Kane, 2018). Et handlingsrom defineres også av organisasjonsstrukturen, som kan være både formell og uformell (Selznick, 1984; Jacobsen \& Thorsvik, 2019). Formelle strukturer koordinerer arbeidsoppgaver og funksjoner i organisasjonen, mens uformelle strukturer framkommer som resultat av at enhver tjenesteutøver har en personlighet, interesser og ønsker som vedkommende bringer inn i organisasjonen (Selznick, 1984).

Handlingsrommet påvirkes også av en leders kompetanse, motivasjon og forståelse. Den enkelte fortolker forventninger, krav og strukturelle føringer, noe som vil prege opplevelsen av muligheter og begrensninger for handling i ethvert handlingsrom (Espedal, Kvitastein \& Grønhaug, 2012). Tilnærmet identiske fenomener kan forstås som begrensninger eller muligheter av ulike yrkesutøvere, fordi regler kan gis alternative fortolkninger. Tilgjengelige ressurser kan for eksempel kombineres på nye måter (Strand, 2007; Slettebø \& van der Meij, 2018). Når ledere evner å se og utnytte muligheter for handling, omtales dette ofte som et subjektivt handlingsrom. Det subjektive handlingsrommet kan forstås som større enn det formelle handlingsrommet, som skapes av tidligere omtalte begrensninger og krav (Espedal \& Kvitastein, 2012). Handlingsrommets muligheter og begrensninger i utøvelse av ledelse blir nærmere belyst i kapittel 6, «Utøvelse av ledelse i kommunale sykehjem - handlingsrommets betydning», som er et empirisk bidrag. Kassah, Nordahl-Pedersen og Tingvoll viser hvordan lederne bruker sitt handlingsrom forskjellig. Det framkommer at noen ledere evner å benytte det subjektive handlingsrommet i sin søken etter løsninger som kan fungere.

Handlingsrommet for tjenesteutøvelse kommer fram gjennom de valgene og beslutningene tjenesteutøvere gjør i krysningspunktet mellom 
krav og begrensninger. Mulighetene for å endre dimensjoner i handlingsrommet som oppleves som begrensende for en tjenestes måloppnåelse, avhenger blant annet av hvor rigid en organisasjonsstruktur er (Espedal \& Kvitastein, 2012). I kapittel 8, «Å skape handlingsrom for pasientsikkerhet i sykehjem - sykepleieres erfaringer med å delta i simulering in situ på sykehjem», belyser Lindgren, Høgbakk, Evju og Wiklund Gustin endringer i handlingsrommet for læring. Kapitlet er et empirisk bidrag som beskriver sykepleieres erfaringer med å delta i simulering in situ og deres refleksjoner knyttet til pasientsikkerhet i sykehjem. I det empiriske bidraget, kapittel 9, «Muligheter og begrensninger i sykepleiernes handlingsrom når sykehjemspasientens sykdomstilstand forverrer seg», belyser Vestly og Løvdal hvordan sykepleiere i kommunale sykehjem erfarer sitt handlingsrom i tjenesteutøvelsen.

\section{Organisasjonsstruktur og ledelse}

Kommunalt barnevern og helse- og omsorgstjenester møter mange utfordringer, og det er trolig behov for endring i institusjonenes organisasjonsstruktur dersom utfordringene skal imøtekommes. For å forstå hvorfor organisasjonsendringer kan være vanskelig, men også nødvendig, blir organisasjonsstruktur og ledelse belyst og diskutert i flere av antologiens bidrag. Det gis her en kort innføring i de perspektivene som ligger til grunn for forståelsen av organisasjon, organisasjonsendring og ledelse i denne antologien.

Forskning om kommunal barneverntjeneste og helse- og omsorgstjeneste viser at forventninger og krav om økt tjenesteproduksjon er utfordrende å imøtekomme (Deloitte, 2019). Dette kan blant annet ha sammenheng med at det er vanskelig å få til endring i organisasjonene, fordi organisasjonsendringer ofte møter motstand (Jacobsen, 2004). Det er mulig at motstand kan føre til at tjenestene møter utfordringene med ad hoc-løsninger og brannslokking. Endringene i organisasjonen kan da bli mindre omfattende i øyeblikket og kan tilpasses eksisterende strukturelt rammeverk. Disse løsningene kan være en form for «systemblindhet» (Argyris \& Schøn, 1978). Systemblindhet framkommer når allerede etablerte grunnleggende antagelser, verdier, normer og artefakter skygger 
for mulighetene til å bli bevisst handlingsrommet for utvikling og endring i organisasjonen.

Endringsmotstand kan forklares på mange måter (Jacobsen \& Thorsvik, 2019), men her tas det utgangspunkt i læring i organisasjoner. Det viser seg at inkrementalistiske endringer, det vil si små endringer, som lett lar seg gjennomføre fordi endringene sjelden rører direkte ved organisasjonens verdigrunnlag. Slike endringer omtales ofte som resultater av «enkeltsløyfet» læring i organisasjoner (Argyris \& Schøn, 1978). Endringene utfordrer ikke ansattes forståelse av hva som er viktige verdier og normer i organisasjonen, og de møter lite motstand fordi de ikke griper dypt inn i ansattes arbeidshverdag. Dyptgående organisasjonsendringer som angår organisasjonens verdier, innebærer «dobbelsløyfet» læring og er vanskeligere å få til. Dette fordi de fører til endringer i både grunnleggende antagelser, verdier, normer og artefakter for organisasjonens virke (Argyris \& Schøn, 1978; Schein, 2004). Dyptgående organisasjonsendringer forandrer ofte etablerte forventninger til jobbutførelse og andre føringer og krav i organisasjonsstrukturen, det vil si ledernes handlingsrom.

Hvordan makt forvaltes, og hvordan maktutøvelse utspiller seg i organisasjoner, har også betydning for hvordan utfordringer forstås og imøtekommes (Juritzen, 2013). Makt er et begrep med lange tradisjoner, og som er gitt ulikt meningsinnhold av forskjellige forfattere i løpet av historien (Machiavelli, 2007; Montesquieu, 1998; Marx, 1971; Weber, 1971; Bourdieau, 1979, 1986; Hernes, 1982). I denne boken er Webers forståelse av makt sentral. Weber forstår makt som at noen får mulighet for å få gjennom sin vilje, selv om andre aktører viser motstand (Weber, 1971). Med Weber kom den relasjonelle forståelsen av hvordan makt kan fungere i en organisasjon, og Webers idé om det profesjonelle, legale byråkratiet har satt sterke spor i forvaltningen. Maktfordelingen i et byråkrati er avhengig av en persons rolle og kompetanse. Samtidig er maktfordelingen også orientert mot sak og skal være rettferdig (Weber, 1971). Dersom makten skal vare over tid, må den være legitim. Forståelsen av begrepene makt og legitimitet bidro til at Weber utvidet makt til også å omfatte sosiale aktiviteter i samfunnet. Legitimiteten og maktfordelingen som kommer til uttrykk i den byråkratiske organisasjonsformen, kan møte utfordringer 
når det stilles nye krav til samhandling og oppgavefordeling i barnevernet og helse- og omsorgstjenesten.

Posisjonsmakt kan defineres som muligheten for legal maktutøvelse som er tillagt en stilling i en organisasjon. Hvordan posisjonsmakten forvaltes, har betydning for hvilke endringer det er mulig å få til i en organisasjons formelle og uformelle organisasjonsstruktur (Argyris, 1977).

Lederens formelle lederposisjon er ingen garanti for at påkrevde endringer i organisasjonen blir gjennomført og blir vellykket ut fra måloppnåelse. Dette fordi andre aktører, for eksempel uformelle ledere, kan ha en sterk definisjonsmakt. Innehavere av en uformell definisjonsmakt i en organisasjon kan påvirke hvordan offentlige pålegg og krav som innebærer endring, imøtekommes.

Innenfor kommunalt barnevern rekrutteres de fleste ledere blant kollegaer. Mange ledere går tilbake til fagstilling etter en tid, og de skal slik leve videre i organisasjonen etter at de har tatt upopulære avgjørelser (Barnevernpanelet, 2011). Det samme mønstret gjør seg gjeldende innenfor kommunal helse- og omsorgstjeneste (Andrews \& Høgås, 2017). Intern rekruttering kan bidra til å utvide ledernes rom for endring, fordi lederne besitter en unik kompetanse om formelle og uformelle maktforhold og om ressurser i organisasjonen. Intern rekruttering av ledere kan imidlertid også ha en negativ effekt på endringspotensialet i organisasjonen, da ledere kan ha en viss systemblindhet. Dette fordi den enkeltes opplevelse av sitt handlingsrom ofte vil være preget av enhetens organisasjonskultur, det vil si grunnleggende antagelser, verdier, normer og artefakter i organisasjonen (Schein, 2004; Hatch, 2001; Nonaka \& Takeuchi, 1995).

Hvis lederes handlingsrom innsnevres på grunn av intern rekruttering, kan lederfunksjonen bli mer preget av administrative oppgaver og i mindre grad av ledelsesoppgaver. Ifølge Strand (2007) kan administrasjon betegnes som iverksetting, oppfølging og kontroll av administrative regler og rutiner. Ledelse og administrasjon er tett sammenvevd, og ledere som lykkes, må kunne håndtere begge funksjoner (Jacobsen \& Thorsvik, 2019). Det er mulig at eksternt rekrutterte ledere kan se andre muligheter for endring i organisasjonen enn internt rekrutterte ledere. Eksternt rekrutterte ledere er ikke sosialisert inn i organisasjonens kultur og er dermed ikke fanget av systemblindhet. 
Det er viktig å problematisere hvordan ledere i kommunalt barnevern og helse- og omsorgstjenester legger til rette for ivaretagelse av tjenestenes samfunnsansvar. Statens helsetilsyn påpeker at den daglige ledelsen og kommunens overordnede styring er viktige årsaker til svikt i for eksempel det kommunale barnevernet. Det er videre behov for å styrke lederkompetansen i både sykehjem og hjemmesykepleie (Barnevernpanelet, 2011; Haycock-Stuart \& Kean, 2012; Statens helsetilsyn, 2015; Moe \& Gotvassli, 2016; Kvello \& Moe, 2014). I kapittel 5, «Ledelse av profesjonalisert velferd i et paradoksteoretisk perspektiv», som baseres på litteraturgjennomgang, belyser Olsvik komplekse, motstridende og motsetningsfylte forhold for ledelse i profesjonalisert velferd. Forfatteren gir uttrykk for at det er behov for å styrke lederkompetansen for å håndtere dilemmaer ved hjelp av paradoksteoretisk tenkning. Ledelse er også viktig for tverrfaglig samarbeid, et tema som belyses i kapittel 2, «Utfordringer i tverrfaglig samarbeid - kommunal helse- og omsorgstjeneste samt kommunalt barnevern». Fredriksen, Kassah og Tingvoll løfter fram ulike utfordringer knyttet til tjenesteutøveres kompetanse når tverrfaglig samarbeid skal benyttes for å ivareta brukeres tjenestebehov i den kommunale helse- og omsorgstjenesten og i kommunalt barnevern.

\section{Avsluttende betraktninger}

De teoretiske begrepene og perspektivene som er belyst i dette kapitlet, gir et innblikk i komplekse sammenhenger for tjenesteutøvelse, ledelse og organisasjonsendringer i det kommunale barnevernet og i helse- og omsorgstjenesten. Handlingsrommet for tjenesteutøvelse og ledelse påvirkes av behov for kompetanse innenfor økonomi og ledelse for å ivareta god kvalitet i kommunal helse og omsorgstjeneste (Helseog omsorgsdepartementet, 2015); Andrews \& Høgås, 2017). Det er også behov for et kompetanseløft innenfor kommunalt barnevern, og Bufdir (2019a) har utviklet en kompetansestrategi med særlig søkelys på å styrke kompetansen innenfor ledelse, jus og utredningsarbeid. Gjennomgangen i dette kapitlet kan tyde på at det er behov for å styrke forståelsen av tjenestens handlingsrom for utøvelse av kompetanse. Et handlingsrom som preges av begrensninger i form av systemblindhet, 
barrierer for læring i organisasjonen og lederparadokser, kan hemme realisering av påkrevde endringer i kommunalt barnevern samt i helseog omsorgstjenesten.

Antologiens ulike bidrag belyser noen sentrale muligheter og begrensninger i handlingsrommet for tjenesteutøvelse i kommunalt barnevern samt helse- og omsorgstjeneste. Det er viktig å merke seg at tverrfaglig samarbeid ofte blir løftet fram som et svar på utfordringer i tjenesteutøvelse. Det tilføres imidlertid ikke kompetanse om hvordan å identifisere og overkomme barrierer for tverrfaglig samarbeid. Resultatet er at det kompetansepotensialet som ligger i denne formen for samarbeid, i liten grad realiseres.

\section{Referanser}

Andrews, T. \& Høgås, J. (2017). Vilkår for ledelse. Om økonomi, kompetanse, ansvar og myndighet $i$ norske helse- og omsorgstjenester (NF-rapport 10/2017). http:// www.nordlandsforskning.no/getfile.php/1319733-1510135519/Dokumenter/ Rapporter/2017/NF-rapport\%2010_2017.pdf

Argyris, C. (1977). Double-loop learning in organizations. Harvard Business Review, $55,115-125$.

Argyris, C. \& Schön, D. (1978). Organizational learning: A theory of action perspective. Reading, MA: Addison-Wesley.

Barne- og likestillingsdepartementet. (2017). Endringer i barnevernloven (barnevernsreform) (Prop. 73 L (2016-2017)). Hentet fra https://www.regjeringen.no Barnevernloven. (1992). Lov om barneverntjenester (barnevernloven) (LOV-1992-0717-100). Hentet fra https://lovdata.no/dokument/NL/lov/1992-07-17-100

Barnevernpanelet. (2011). Barnevernpanelets rapport. Hentet fra https://www. regjeringen.no/globalassets/upload/bld/barnevern/2011/barnevernpanelets_ rapport.pdf

Bourdieu, P. (1979). La distinction. Paris: Editions de Minuit.

Bourdieu, P. (1986). The forms of capital. I J. G. Richardson (Red.), Handbook of theory and research for the sociology of education (s. 241-258). Westport, CT: Greenwood.

Barne-, ungdoms- og familiedirektoratet. (2019a). Utredning av kompetansehevingstiltak i barnevernet (Rapport nr. 04/2019). Hentet fra https://bufdir.no/globalassets/ bufdirs-kompetanseutredning-endelig.pdf

Barne-, ungdoms- og familiedirektoratet. (2019b). Mer kunnskap - bedre barnevern. Kompetansestrategi for det kommunale barnevernet 2018-2024. Hentet fra https:// 
www.regjeringen.no/contentassets/6e31905299774f5681d57311e284d519/bedrebarnevern.pdf

Deloitte. (2019). Forsøk med ny ansvarsfordeling mellom stat og kommune på barenvernområdet. Følgeevaluering (Delrapport 4). Hentet fra https://www. regjeringen.no/contentassets/b87f5a6boeo5436587c911od2ae75884/folgeevalueringav-forsok-med-ny-ansvarsfordeling-pa-barnevernomradet_endeligrapport-01102019.pdf

Dweck, C. S. (2002). Beliefs that make smart people dumb. I R. J. Sternberg (Red.), Why smart people can be so stupid (s. 22-41). New Haven, CT: Yale University Press.

Espedal, B. \& Kvitastein, O. A. (2012). Rom for læring: Betydningen av handlingsrom for ledelse. Magma, 8, 30-38.

Espedal, B., Kvitastein, O. A. \& Grønhaug, K. (2012). When Cooperation is the norm of appropriateness: How does CEO cooperative behavior affect organizational performance? British Journal of Management, 23(2), 257-271.

Forskrift om nasjonal retningslinje for sykepleierutdanning. (2019). Forskrift om nasjonal retningslinje for sykepleierutdanning (FOR-2019-03-15-412). Hentet fra https://lovdata.no/dokument/SF/forskrift/2019-03-15-412

Hambrick, D. C. \& Mason, P. A. (1984). Upper echelons: The organization as a reflection of its top managers. The Academy of Management Review, 9(2), 193-206. https://doi.org/10.2307/258434

Hambrick, D. C. (2007). Upper echelons theory: An update. The Academy of Management Review, 32(2), 334-343. https://doi.org/10.2307/20159303

Hatch, M. J. (2001). Organisasjonsteori. Moderne, symbolske og postmoderne perspektiver. Oslo: Abstrakt.

Haycock-Stuart, E. \& Kean, S. (2012). Does nursing leadership affect the quality of care in the community setting? Journal of Nursing Management, 20(3), 372-381.

Helse- og omsorgsdepartementet. (2009). Samhandlingsreformen - Rett behandling på rett sted - til rett tid (St.meld. nr. 47 (2008-2009)). Oslo: Helse- og omsorgsdepartementet.

Helse- og omsorgsdepartementet. (2013). Morgendagens omsorg (Meld. St. 29 (2012-2013)). Hentet fra https://www.regjeringen.no

Helse- og omsorgsdepartementet. (2015). Framtidens primorhelsetjeneste - noerhet og helhet (Meld. St. 26 (2014-2015)). Hentet fra https://www.regjeringen.no

Helse- og omsorgstjenesteloven. (2011). Lov om kommunale helse- og omsorgstjenester m.m. (LOV-2011-06-24-30). Hentet fra https://lovdata.no/ dokument/NL/lov/2011-06-24-30

Hernes, G. (1982). Makt og avmakt: en begrepsanalyse (2. utg.). Oslo: Universitetsforlaget.

Imsen, G. (2011). Hva er pedagogikk? Oslo: Universitetsforlaget. 
Jacobsen, D. I. (2004). Organisasjonsendringer og endringsledelse. Bergen: Fagbokforlaget.

Jacobsen, D. I. \& Thorsvik, J. (2019). Hvordan organisasjoner fungerer (5. utg.). Bergen: Fagbokforlaget.

Juritzen, T. I. (2013). Omsorgsmakt - Foucaultinspirerte studier av maktens hvordan $i$ sykehjem (Doktoravhandling). Oslo: Universitetet i Oslo.

Karoliussen, M. (2015). Tilbake til kjerneverdiene. Sykepleien, 103(2), 62-64. https:// doi.org/10.4220/sykepleiens.2015.0001

Kassah, B. L. L., Tønnessen, S. \& Tingvoll, W.-A. (2014). Samhandlingsreformen utfordringer, løsninger og implikasjoner. I B. L. L. Kassah, W.-A. Tingvoll \& K. A. Kassah (Red.), Samhandlingsreformen under lupen. Kvalitet, organisering og makt $i$ helse- og omsorgstjenestene. Bergen: Fagbokforlaget.

Kvello, Ø. \& Moe, T. (Red.). (2014). Barnevernledelse. Oslo: Gyldendal.

Lai, L. (2013). Strategisk kompetanseledelse (3. utg.). Bergen: Fagbokforlaget.

Lai, L. (2014). Makt og påvirkningskraft: hvordan få gjennomslag på jobb. Oslo:

Cappelen Damm Akademisk.

Machiavelli, N. (2007). Fyrsten. Oslo: Kagge Forlag.

Marx, K. (1971). Kapitalen 1. Verker i utvalg, bind V. Oslo: Pax Forlag. (Opprinnelig publisert i 1867)

Martinussen, W. (1991). Sosiologisk analyse. En innføring (3. utg.). Oslo: Universitetsforlaget.

Moe, T. og Gotvassli, K.-Å. (2016). Å lede til barns beste - Hvordan kan lederutdanning i barnevernet svare på barnevernets behov for økt lederkompetanse? Tidsskriftet Norges barnevern, 93(3-4).

Montesquieu, C. (1998). De l'esprit des loix (Lovenes ånd). Genève: Chez Barrillot et Fils. (Opprinnelig utgitt 1748)

Nonaka, I. \& Takeuchi, H. (1995). The knowledge creating company: How Japanese companies create the dynamics of innovation. Oxford, England: Oxford University Press.

Polanyi, M. (1983). The tacit dimension. Gloucester, MA: Peter Smith.

Ringholm, T. \& Holmen, A. K. T. (2019). Innovasjon i møtet mellom idé og institusjon. I A. K. T. Holmen \& T. Ringholm (Red.), Innovasjon møter kommune. (s. 13-27). Oslo: Cappelen Damm Akademisk.

Sandberg, J. (200o). Understanding human competence at work: An interpretative approach. Academy of Management Journal, 43(1), 9-25.

Schiefloe, P. M. (2019). Mennesker og samfunn. Innføring i sosiologisk forståelse (3. utg.). Bergen: Fagbokforlaget.

Schein, E. H. (2004). Organizational culture and leadership (3. utg.). San Francisco, CA: John Wiley \& Sons. 
Schönfelder, W., Andersen, S. T. \& Kane, A. A. (2018). Handlingsrom i barnevernet. I W. Schönfelder, S. T. Andersen \& A. A. Kane (Red.), Handlingsrom $i$ barnevernet. Muligheter og begrensninger for profesjonsutøveren (s. 13-20). Bergen: Fagbokforlaget.

Schönfelder, W. \& Holmgaard, S. B. (2019). Representations of child welfare services in Norwegian, Danish and German newspapers. Children and Youth Services Review 100, 89-97.

Selznick, P. (1984). Leadership in administration. A sociological interpretation. Berkeley, CA: University of California Press.

Slettebø, T. \& van der Meij, R. (2018). Sosial innovasjon og tjenesteutvikling i barnevernet. I W. Schönfelder, S. T. Andersen \& A. A. Kane (Red.), Handlingsrom i barnevernet. Muligheter og begrensninger for profesjonsutøvere (s. 87-108). Bergen: Fagbokforlaget.

Stamsø, M. A. (Red.). (2017). Velferdsstaten i endring. Om norsk helse- og sosialpolitikk (3. utg.). Oslo: Gyldendal Akademisk.

Statens helsetilsyn. (2015). Helsetilsynet: tilsyn med barnevern, sosial- og helsetjenestene (Årsrapport 2015). Hentet fra https://www.helsetilsynet.no/ globalassets/opplastinger/publikasjoner/aarsrapporter/aarsrapport2015.pdf

Strand, T. (2007). Ledelse, organisasjon og kultur (2. utg.). Bergen: Fagbokforlaget.

Tingvoll, W-A., Kassah, B. L. L. \& Kassah, K. A. (2014). Helse- og omsorgstjenestene - et overblikk. I B. L. L. Kassah, W-A. Tingvoll \& K. A. Kassah (Red.), Samhandlingsreformen under lupen. Kvalitet, organisering og makt i helseog omsorgstjenestene. (s. 17-29). Bergen: Fagbokforlaget.

Trana, H. M. (2013). Kjærlighet: en kjernekompetanse i profesjonelt barnevernsarbeid? Tidsskriftet Norges barnevern, 9o(1), 5-17.

Volberda, H. W. \& Elfring, T. (2001). Rethinking strategy. Thousand Oaks, CA: Sage Publications.

Weber, M. (1971). Makt og byråkrati. Oslo: Gyldendal.

Yukl, G. A. (2012). Leadership in organizations (8. utg.). Upper Saddle River, NJ: Prentice Hall. 



\title{
Utfordringer i tverrfaglig samarbeid. Kommunal helse- og omsorgstjeneste samt kommunalt barnevern
}

\author{
Sven-Tore Dreyer Fredriksen, Bente Lilljan Lind Kassah og \\ Wivi-Ann Tingvoll
}

UiT Norges arktiske universitet

\begin{abstract}
This chapter on the challenges of interdisciplinary co-operation between Municipal Health/Social Care and Child Protection respectively is based on the directives of public authorities that interactions often challenge interdisciplinary co-operation. The research studies on which we based the discussion indicate that there are several challenges associated with this form of co-operation. The discussion has its basis in the social constructivist perspective, where the focus is on the implications of the ontologies and epistemologies for interdisciplinary co-operation. Further, the discussion shows that interdisciplinary co-operation challenges the hierarchy of knowledge and user participation within the services. The chapter argues that interdisciplinary co-operation has, to some extent, the potential for further knowledge development.
\end{abstract}

Keywords: interdisciplinary co-operation, ontology, profession, nursing, child welfare, knowledge development

$1 \quad$ Forfatterne er likeverdige bidragsytere.

Sitering av denne artikkelen: Fredriksen, S.-T. D., Kassah, B. L. L. \& Tingvoll, W.-A. (2020). Utfordringer i tverrfaglig samarbeid. Kommunal helse- og omsorgstjeneste samt kommunalt barnevern. I B. L. L. Kassah, H. Nordahl-Pedersen \& W.-A. Tingvoll (Red.), Handlingsrom for profesjonalisert velferd: Kommunale tjenester for helse, omsorg og barnevern (Kap. 2, s. 27-45). Oslo: Cappelen Damm Akademisk. https://doi.org/10.23865/noasp.114.ch2

Lisens: CC-BY 4.o. 


\section{Introduksjon}

Kommunale helse- og omsorgstjenester og kommunalt barnevern opplever både økt press på tjenestene og kompetansemangel (Wettergren, Ekornrud \& Abrahamsen, 2019; Røsdal, Nesje, Aamodt, Larsen \& Tellmann, 2017). Årsakene er blant annet omfattende samfunnsendringer knyttet til sentraliseringsprosesser, kulturelt mangfold, demografiske endringer, komplekse sykdomsbilder og økt omsorgsbehov. Samfunnsendringene skaper behov for endring i organisering, ledelse, tjenestetilbud, kompetanse og sammensetning samt bedre ressursforvaltning for å styrke faglig kvalitet. Tjenestenes handlingsrom (se kapittel 1) for å imøtekomme endringspresset har betydning for utviklingen av fullverdige faglige tilbud til den enkelte tjenestemottakeren i behandlingsog omsorgskjeden (Kassah, Tingvoll \& Fredriksen, 2014; Helse- og omsorgsdepartementet, 2009). Tradisjonelt har helse- og omsorgstjenestene samt barneverntjenesten vært organisert ut fra profesjonelle og faglige funksjonsområder, noe som har utfordret den enkelte profesjon og semiprofesjon på helhetstenkning og koordinering av tjenester. I stortingsmeldinger og retningslinjer som har kommet de siste årene, fremkommer det et behov for økt tverrfaglig samarbeid i henholdsvis helse- og omsorgstjenesten samt barneverntjenesten (Helse- og omsorgsdepartementet, 2020); Barne- og likestillingsdepartementet, 2017). I samhandlingsreformen (Helse- og omsorgsdepartementet, 2009) fremheves det for eksempel at både intra- og interorganisatorisk samhandling vil forbedre kvaliteten på helse- og omsorgstjenestene. Disse politiske dokumentene gir ytre føringer for helse- og omsorgstjenestene samt for barnevernstjenestens handlingsrom med hensyn til samarbeidsformer.

I dette kapitlet søker vi å belyse sentrale utfordringer som gjør det vanskelig å realisere tverrfaglig samarbeid innenfor både kommunal helse- og omsorgstjeneste og kommunal barneverntjeneste. Disse tjenestene møter utfordringer knyttet til tverrfaglig samarbeid som har mange fellestrekk, noe som kan utfordre ønsket om et helhetlig tjenestetilbud innenfor sykepleie og barnevern. På bakgrunn av tidligere forskning om samarbeid diskuterer vi utfordringer knyttet til fagenes ontologi, epistemologi og profesjonshierarki som sentrale for å realisere tverrfaglig samarbeid i kommunal sykepleie- og barneverntjeneste. Hensikten med kapitlet 
er å tydeliggjøre sammenhenger mellom kunnskapssyn og handlingsrom for tverrfaglig samarbeid. Temaet er viktig av mange grunner, men spesielt fordi politiske myndigheter ønsker økt tverrfaglig samarbeid i blant annet kommunale helse- og omsorgstjenester for å ivareta tjenestemottakere med stadig mer komplekse og sammensatte pleie- og omsorgsbehov (Helse- og omsorgsdepartementet, 2009). Økt behov for tverrfaglig samarbeid er blant annet et resultat av at oppgaver som tidligere ble ivaretatt i spesialisthelsetjenesten, nå skal ivaretas i kommunal omsorgstjeneste der det er lav normering av sykepleiere og spesialsykepleiekompetanse (Ugreninov, Vedeler, Heggebø \& Gjevjon 2017). En konsekvens av sykepleiefaglig kompetansemangel i kommunal omsorgstjeneste er at arbeidsoppgaver ofte delegeres til ukvalifisert personale (Ugreninov et al., 2017). Dette utfordrer tjenestene når det gjelder både kvalitet og forsvarlighet (Kassah \& Tønnessen, 2016; Tønnessen, 2011). I barneverntjenesten er det behov for å involvere flere faggrupper og profesjoner i kommunal barnevernvirksomhet fordi det erfares en sterk økning i antall meldte saker (Støkken, 2014). Samtidig fremkommer det at barnevernet har utfordringer knyttet til det å delta i tverrfaglig samarbeid (Baklien, 2009; Fossum, Lauritzen, Vis \& Ottosen, 2015). Barneverntjenesten oppleves som orientert mot formularer og paragrafer uten at innholdet utdypes, noe som gjør vanskeliggjør samarbeid med andre fagfolk (Flaten, Brustad, Svendsen \& Gjevre, 2013). Dette til tross for at det i både offentlige dokumenter og forskning påpekes at det er behov for å styrke det tverrfaglige samarbeidet i barnevernet (Barne- og likestillingsdepartementet, 2017). Det fremkommer imidlertid at flere formaliserte samarbeid med det kommunale barnevernet fungerer, blant annet arbeid knyttet til det å få inn bekymringsmeldinger på et tidlig tidspunkt (Breimo, Lo, Anvik \& Sandvin, 2019). Utfordringer i samarbeid kan trolig også knyttes til at det benyttes flere ulike begreper for å beskrive samarbeid i tjenestene. Begreper som betegner samarbeid, har ofte ulikt meningsinnhold, noe som kan bli spesielt tydelig når samarbeidsprosesser skal settes i gang. Ulike forståelser av samarbeidets innhold og form kan skape utfordringer når flere kompetanser skal benyttes for å ivareta helhetlige tjenester innenfor sykepleie og barnevern.

Samhandling omfatter tjenestenes evne til å fordele oppgaver internt for å nå et felles, omforent mål (Orvik, 2015). Samtidig omfatter 
samhandling evnen til å gjennomføre oppgaver på en koordinert og rasjonell måte. Ifølge Vik (2018) knyttes utfordringer i samhandling til lokale retningslinjer, fravær av møteplasser og manglende kunnskap om ulike profesjoners fagutøvelse. Vellykket samhandling blir ofte beskrevet som relasjoner preget av likeverdighet og gjensidig kunnskap om hverandres fagfelt.

Begrepene tverrfaglig samhandling og tverrfaglig samarbeid benyttes ofte om hverandre. I dette kapitlet benyttes begrepet tverrfaglig samarbeid, en arbeidsform som ofte betraktes som en mulig løsning på mange av de utfordringer som både sykepleie- og barneverntjenesten møter (Helse- og omsorgsdepartementet, 2012). Tverrfaglig samarbeid benyttes ofte i offentlige dokumenter (Verdens helseorganisasjon, 2010; Helse- og omsorgsdepartementet, 2009), i ulike faglige sammenhenger og i forskjellige praksisfelt (Glavin \& Erdal, 2013). Ulike dokumenter beskriver tverrfaglighet som samarbeid mellom flere faggrupper mot et felles mål (Lauvås \& Lauvås, 2004; Helse- og omsorgsdepartementet, 2014-2015a).

Begrepet flerfaglighet benyttes noen ganger synonymt med tverrfaglig samarbeid for å betegne samarbeid mellom ulike profesjoner og faggrupper (Lauvås \& Lauvås, 2004). Flerfaglighet beskrives som at hver enkelt fagprofesjon belyser en faglig problemstilling ut fra eget ståsted, men ikke nødvendigvis samtidig på en arena der flere fag og profesjoner skal samarbeide. Flerfaglighet omtales som et samarbeid mellom flere faggrupper som jobber i en parallell og koordinert prosess. Et eksempel kan være når barn som har vært utsatt for omsorgssvikt, mottar hjelpetiltak og det er behov for samarbeid mellom barnevernansatte og helsesykepleiere. I et slikt samarbeid benyttes fagområdenes særegne kompetanse, noe som innebærer at samarbeidspartnerne ikke overskrider faggrensene til andre faggrupper. I interaksjonen inngår dog noen grad av nærhet og avhengighet, hvor observasjoner, tjenestemottakeres situasjon og intervensjoner diskuteres. Hver og en gjør sitt arbeid, de møtes, og de rapporter om framdriften i arbeidet. Tverrfaglighet fordrer imidlertid, ifølge Lauvås og Lauvås (2004), at ulike fagdisipliner integreres i en felles forståelse basert på hverandres kunnskaps- og beslutningsgrunnlag gjennom et kontinuerlig samarbeid. Samarbeidet skal preges av at den enkelte profesjonens fagspesifikke kunnskap skal deles og anerkjennes i 
fellesskapet. Tverrfaglig samarbeid er rettet mot et felles mål, der profesjonene er gjensidig og kollegialt avhengig av hverandre for å ta avgjørelser og gjennomføre beslutninger (Collin, Valleala, Herranen \& Paloniemi, 2011). Et eksempel på endring i funksjons- og ansvarsforhold kan være når sykepleiere forventes å ivareta flere medisinske behandlingsoppgaver som i hovedsak tilhører den medisinske profesjonen (Helse- og omsorgsdepartementet (2014-2015a)). Et eksempel innenfor barneverntjenesten kan knyttes til kjærlighet som en kjernekompetanse i barnevernarbeid (Thrana, 2014), fordi ansatte kan ivareta ansvar ut fra nærhet og tillit i relasjonen til den unge.

Et annet viktig aspekt som løftes fram i politiske føringer, som også har betydning for tverrfaglig samarbeid, er det grunnleggende kunnskapssynet i hvert enkelt fag og i tjenesteutøvelsen (Helse- og omsorgsdepartementet, 2014-2015a, 2015b, 2016). I samhandlingsreformen (Helse- og omsorgsdepartementet, 2009) legges det føringer for at tjenestene innenfor helse og omsorg skal være kunnskapsbasert, noe som innebærer at bruker- og profesjonserfaringer samt forskning skal anvendes som kunnskapsgrunnlag for tjenestene. Innenfor sykepleiefaget er kunnskapsbasert praksis utviklet og til en viss grad integrert i både utdanning og praksisfelt. I barneverntjenesten har tjenesteutøvelsen i stor grad hatt søkelys på evidensbasert kunnskap (Bjørnebekk, 2010). Ideen om et kunnskapsbasert barnevern er imidlertid framtredende i offentlige førende dokumenter (Deloitte, 2019).

Det dominerende kunnskapssynet i tjenestene får også konsekvenser for den skjønnsvurderingen som gjøres i samarbeidet mellom tjenesteutøvere. Kari Martinsen (2005) hevder at det å handle skjønnsmessig er å kunne overveie de alternativene som finnes i situasjonen, slik at det gagner den enkelte best mulig. Skjønn som utøves med rammer i en evidensbasert kunnskapsforståelse, skiller fakta fra vurderinger, noe som utelater tjenesteutøverens profesjonsskjønn (Bjørnebekk, 2010; K. Martinsen, 2005). Et slikt tankesett kan innebære at profesjonsskjønnet kun blir et implisitt aspekt hos profesjonsutøverne, og som derfor ikke fremkommer i dialog, samarbeidsprosesser og faglig dokumentasjon. Hvis kunnskapen som ligger til grunn for profesjonsskjønnet, forblir implisitt, kan denne kunnskapen forbli en privatisert og taus kunnskap (Polanyi, 
1967). En kunnskap som ikke verbaliseres, kan slik bli et kunnskapstap for den enkelte profesjonen og det enkelte faget samtidig som det kan være vanskelig å aktivere denne kunnskapen i et tverrfaglig samarbeid. Taus kunnskap kan slik bli en utfordring i tverrfaglig samarbeid fordi premissene for de avgjørelsene som tas når skjønnet utøves, blir lite tydelige og kanskje i noen sammenhenger direkte uforståelige for samarbeidende parter. Utydelige premisser for å foreta beslutninger kan i verste fall føre til at samarbeidspartene konsentrerer seg om enkelte tiltak, mens andre ikke blir «sett», noe som kan forringe kvaliteten i tjenestetilbudet.

\section{Teoretisk rammeverk}

Artikkelens diskusjoner er fundamentert i et sosiologisk konstruktivistisk perspektiv (Berger \& Luckmann, 1966) og en vitenskapsteoretisk tilnærming som har utgangspunkt i Schutz, (1970) sin fenomenologiske forståelse. I et sosialkonstruktivistisk perspektiv betraktes virkeligheten som sosialt konstruert gjennom eksternaliserings-, objektiverings-, sosialiserings- og internaliseringsprosesser (Berger \& Luckmann, 1966). Disse prosessene foregår kontinuerlig og om hverandre i samfunnet. Eksternalisering viser til at vi skaper eller vedlikeholder ulike sosiale fenomener. Det er for eksempel laget en sosial konstruksjon, om enn noe utydelig definert, som vi benevner tverrfaglig samarbeid. Objektiveringsprosesser viser til at de sosiale konstruksjonene får en egen eksistens. Det vil si at det i ulike situasjoner rettes forventninger til den enkelte om å utvise en bestemt atferd, fordi objektiveringen forankrer forventningene i strukturen som innrammer enhver sosial samhandling. Årsaken til at vi ofte handler slik som det forventes av oss, er at vi sosialiseres, læres opp, i blant annet rolleatferd. Når vi handler som forventet, uten å tenke gjennom handlingen, er kunnskapen om hvordan vi skal agere i bestemte kontekster, blitt en del av oss, den er internalisert gjennom sosialiseringsprosesser. Det sosialkonstruktivistiske vitenskapsteoretiske utgangspunktet innebærer at tverrfaglig samarbeid betraktes som sosialt konstruert. Dette betyr at det er rom for endring og alternative konstruksjoner før det eventuelt objektiveres en forståelse som virker inn på deltakerne i tverrfaglig samarbeid, slik at de handler i 
tråd med definisjonen og de forventningene som ligger til atferd i tverrfaglig samarbeid.

\section{Ontologi og epistemologi}

De ulike fagene plasseres innenfor ulike tradisjoner, alt etter hvilken ontologi og epistemologi som bestemmer hva som betraktes som kunnskap, og hvordan denne kunnskapen utvikles (Aadland, 2011). Ontologi kan forstås som den virkelighetsforståelsen som ligger til grunn for hva som betraktes som kunnskap, mens epistemologi omhandler hvordan kunnskap utvikles innenfor ulike ontologier (Blaikie, 2003). Selve forståelsen av hva som er kunnskap, og av hvordan kunnskapen utvikles, er i vår kultur sterkt preget av det naturvitenskapelige paradigmet, der det utvikles sann kunnskap om ulike målbare fenomener, kausale forklaringer og så videre. Innenfor et humanistisk paradigme og et sosialkonstruktivistisk perspektiv og kunnskapssyn betraktes kontekst og kunnskap som tett forbundet; kunnskapen er kontekstuell. Naturvitenskapens definisjonsmakt (Engelstad, 2009) har bidratt til å skape et hierarki innenfor de ulike vitenskapene der humanistisk vitenskap har måttet kjempe for sin eksistens som vitenskap på grunn av en annen ontologi og epistemologi (Guneriussen, 1996). Ulike kunnskapssyn innenfor en profesjon og semiprofesjon vil aktualiseres i tjenesteutøvelsen fordi ansatte beveger seg mellom ulike kunnskapsforståelser, avhengig av hvilke kompetansebehov som fremkommer i møtet med tjenestemottakere i ulike situasjoner. I den konkrete situasjonen kan imidlertid tjenesteutøvers oppmerksomhet og tilnærming i tjenesteutøvelsen styres av lojalitet til det kunnskapssynet som vedkommende har gjort til sitt (Thisted, 1990).

Fagene sykepleie og barnevernspedagogikk er satt sammen av ulike fagområder med ulike ontologier og epistemologier. Begge fagene er sammensatt av humanistiske, naturvitenskapelige og samfunnsvitenskapelige fagområder (Forskrift om nasjonal retningslinje for sykepleierutdanning, 2019; Forskrift om nasjonal retningslinje for barnevernspedagogutdanning, 2019). Sykepleie som fag har for eksempel ulike kunnskapssyn forankret i to ontologiske kunnskapstradisjoner, der den humanistiske ontologien kan sies å være dominerende. Faglig 
beveger sykepleie seg i et felt mellom eksistensielle, etiske, medisinske og juridiske problemstillinger. Barnevernspedagogutdanningen domineres av humanistiske fag og er satt sammen av sosialpedagogikk, sosialantropologi, statsvitenskap og sosiologi. Juridisk kunnskap og psykologi er også sentrale fagområder i utdanningen. Innenfor psykologi er det særlig tilknytningsteori som har fått betydelig fotfeste i barnevern, men det skjer nå en viss endring, og familiers økonomiske og sosiale rammebetingelser for omsorg blir sterkere fokusert (Fauske, Kvaran \& Lichtwarck, 2017). Barnevernspedagogikk som fag er med andre ord forankret i den humanistiske kunnskapstradisjonen, men vektleggingen på evidensbasert kunnskap i barnevernarbeid reflekterer også et kunnskapsideal som er naturvitenskapelig orientert (Støkken, 2014). Profesjonsfagene binder i praksis sammen kunnskap fra ulike vitenskaper, slik at kunnskapsbrokker blir til et hele gjennom praktiske synteser (Grimen, 2008).

I begge tjenestene er møtet med mennesker i utfordrende eller truende livssituasjoner i sentrum, noe som understreker behovet for å aktivere flere ulike kunnskapssyn i tjenesteutøvelsen. I møtet med den andre er det behov for kunnskap om hvordan imøtekomme det andre menneskets behov og interesser. Det er samtidig behov for at tjenesteutøvere reflekterer over de observasjoner og opplysninger som fremkommer i ulike situasjoner og kontekster, før det bestemmes hvordan det kan interveneres i situasjonen (Benner \& Wrubel, 2001). Dette kan innebære tre forhold: Yrkesutøveren kan forstå menneskets situasjon, dets erfaringer og kulturelle bakgrunn samt det at mennesket alltid er glad i noe eller noen. Det andre forholdet omfatter at yrkesutøveren må rette oppmerksomheten mot de fenomenene tjenestemottakeren er opptatt av, og for det tredje forholdet er søkelyset rettet mot at tjenesteyterne i samarbeid med tjenestemottakeren finner løsninger eller svar som ivaretar tjenestemottakerens ønsker og velvære. For å ivareta nevnte forhold balanserer ofte tjenesteutøver mellom kunnskap som er forankret i både en humanistisk og naturvitenskapelig ontologi. Når tjenesteutøver skal utvikle løsninger for intervensjon, vil for eksempel både evidensbasert kunnskap og kvalitativt utviklet kunnskap bli aktualisert. Samtidig vil det også foregå et samspill mellom kunnskap knyttet til brukererfaringer og profesjonserfaringer (Graverholt, Jamtvedt, Nordheim, Nortvedt \& Reinar, 2012). 
Tjenesteutøvers vurderinger involverer flere kunnskapsformer, og kunnskapen kan slik betraktes som praktiske synteser og bevegelig kunnskap, det vil si at aktiveringen av kunnskap er kontekst- og situasjonsavhengig (Fredriksen, 2011; Grimen, 2008). Tjenesteutøvelsen i både sykepleie og barnevern foregår trolig i et spenningsfelt knyttet til ulike kunnskapssyn, noe som kan få betydning for hvilken kunnskap som blir ansett som viktig og «sann» i prioriterings-, utrednings- og beslutningsprosesser innenfor kommunale tjenester. Hvis denne diskusjonen knyttes til tverrfaglig samarbeid, kommer en kompleks samarbeidssituasjon til syne. Dette fordi alle samarbeidende aktører bringer sine fag til samarbeidsarenaen, og hvem som får definere hva som er «sann» kunnskap i situasjonen, kan være et spørsmål om hvem som blir hørt og får gjennomslag for sin kunnskapsforståelse - hvem som har definisjonsmakten (Goffman, 2009).

I møtet med den andre vil den ontologiske forståelsen som aktører sosialiseres inn i gjennom utdanning, virke bestemmende for opplevd kunnskapsbehov. Samtidig foregår det sosialiserings- og internaliseringsprosesser i enhver organisasjon som former yrkesutøvers kunnskap, slik at vedkommende blir satt i stand til å ivareta tjenesteutøvelsen i pakt med organisasjonens mål og hensikt (Selznick, 1984). En organisasjons kunnskap er nedfelt i formelle og uformelle strukturer, og den virker styrende på hvordan tjenesteutøverne opplever kunnskapsbehovet (Nonaka \& Takeuchi, 1995). Dette impliserer at det som ofte omtales som «å sitte i veggene» med hensyn til for eksempel utredning og intervensjonsmuligheter, både kan begrense og utvide tjenesteutøvernes handlingsrom, alt etter hvilken ontologisk forståelse som er dominerende på hver enkelt arbeidsplass. Det er mulig at tverrfaglig samarbeid krever økt bevissthet om eget ontologisk ståsted, og om hvordan egen kunnskapsforståelse påvirker samhandling internt $\mathrm{i}$ en organisasjon og $\mathrm{i}$ et tverrfaglig handlingsrom.

Brukermedvirkning innebærer å omfordele og omstrukturere maktrelasjoner (Askheim, 2007) og kan for eksempel ha forskjellig meningsinnhold i ulike kontekster, alt avhengig av hvilken ontologisk forståelse tjenesteutøvere med definisjonsmakt $i$ et tverrfaglig samarbeid har. I denne sammenhengen kan det være viktig å skille mellom brukermedvirkning som foregår på et strukturelt nivå ved at brukere integreres i 
ulike organer der det foregår utredninger og fattes beslutninger, og brukermedvirkning i mer uformelle kontekster der ulike tjenesteutøveres forståelse av begrepet brukermedvirkning kan bli utslagsgivende for tjenestemottakers innflytelse. Forskning innenfor sykepleie viser for eksempel at kravet om brukermedvirkning er utfordrende å imøtekomme (Kvilhaugsvik \& Husøy, 2017). I kommunale helse- og omsorgstjenester, for eksempel innenfor rehabilitering, kan det bli fattet beslutninger om å tilbakeføre pasienter fra spesialisthelsetjenesten til kommunal helse- og omsorgstjeneste uten at det har vært dialog med pasientene om hvilke kommunale oppfølgingstilbud som skal iverksettes ved utskriving (Kassah, Tingvoll \& Fredriksen, 2014; Tingvoll \& Fredriksen, 2011).

I barnevernet får barn og unge begrenset informasjon fra barnevernet samtidig som de har liten mulighet for å bidra med informasjon selv når deres sak blir undersøkt (Strandbu, 2008; Gulbrandsen, Seim \& Ulvik, 2016; Sandbæk, 2002; Thrana, 2008; Skivenes, 2015). Jensen (2016) viser videre at det er behov for kunnskap om åpen og skjult utøvelse av makt, og om hvordan makt bidrar til - og konstruerer - samhandling og praksis for medvirkning i barnevernet. Det er også mulig at Bufetats satsing på evidensbaserte arbeidsmodeller kan bidra til at barns og unges brukermedvirkning begrenses. «Parent Management Training Oregon» (PMTO) medfører at barnets stemme blir svak (J. T. Martinsen, 2012), og multisystemisk terapi (MST) retter søkelyset mot foreldrekompetanse, og det er lite oppmerksomhet på de unges medvirkning (Christiansen, 2012). Begge de kommunale tjenestenes problemer med å imøtekomme kravet om brukermedvirkning kan ha mange forklaringer, men et handlingsrom preget av spenninger mellom ulike ontologier kan i seg selv være hemmende for tjenesteutøvernes ivaretakelse av brukermedvirkning. I kommunal barneverntjeneste kan det for eksempel være etablert forskjellige uformelle forståelser blant tjenesteutøverne i ulike tjenester om hva brukermedvirkning er. Dette kan bidra til at det å samtale med barn og unge betraktes som tilstrekkelig brukermedvirkning i en tjeneste, men ikke i en annen (Paulsen, 2016). Innenfor tilbud om ettervern er svak brukermedvirkning en sentral årsak til at mange unge ikke ønsker hjelp fra barnevernet etter fylte 18 år (Paulsen, 2016). Kravet om brukermedvirkning kan være spesielt krevende i tverrfaglig samarbeid hvis den 
enkelte tjenesten sliter med å realisere det lovpålagte kravet internt. Det er slik mulig at brukermedvirkning som innebærer at brukerkunnskap aktualiseres, og at brukeres erfaringer og fortolkninger anerkjennes og respekteres, får trangere kår i tverrfaglig samarbeid. Den dikotome relasjons- og maktforståelsen mellom bruker og tjenesteutøver som ofte rammer inn forståelsen av brukermedvirkning, kan da bli tydeligere, men omfordeling av makt kan bli mer utfordrende, da flere aktører skal avgi makt til bruker for å etablere en mer balansert samhandlingsrelasjon. Denne korte redegjørelsen og diskusjonen tyder på at spenninger mellom ulike kunnskapssyn i hver enkelt profesjon og semiprofesjon kan være «med på lasset» når aktører møtes i et felles handlingsrom for tverrfaglig samarbeid.

\section{Profesjonshierarki}

Andre utfordringer i tverrfaglig samarbeid kan videre knyttes til profesjonenes innflytelse og status i et tverrfaglig handlingsrom. Diskusjoner om profesjoner og profesjoners plass i samfunnet har lange tradisjoner, og Weber (2000) betrakter for eksempel profesjoner som lukkede grupper som arbeider med egne oppgaver og for gruppenes interesser. Gruppene har med andre ord enerett til å skaffe seg makt, status og penger. Parsons (1951) har et mer individorientert perspektiv på profesjoner, da han legger vekt på at profesjoner skal utføre bestemte oppgaver overfor vanskeligstilte og nødtrengende på vegne av samfunnet. Ifølge Foucault (1991) har profesjoner en disiplinerende funksjon ved at de kontrollerer det enkelte mennesket. Profesjoner betraktes som grupper som utøver sosial disiplin på vegne av staten. Disse ulike sosiologiske tilnærmingene kan sies å reflektere et institusjonsperspektiv, et individperspektiv og et samfunnsperspektiv. De overnevnte dimensjonene gjenfinnes i nåtidens forståelse av profesjoner, som hos for eksempel Grimen (2008), som legger vekt på at en profesjon er en yrkesgruppe som har en bestemt kunnskap, og som har fått politisk legitimitet for et samfunnsoppdrag. Nortvedt (2008a) gir uttrykk for at profesjonenes virke hovedsakelig befinner seg i relasjonen mellom den profesjonelle og klienten; menneskene er de sentrale. Nortvedt (2008b) representerer en profesjonsforståelse der mennesket, 
omsorg og empati står sentralt. En yrkesgruppe som hevder å inneha en spesiell kunnskap, og som sier at den ivaretar en parts interesser, kan ifølge Eriksen og Molander (2008) også betraktes som en profesjon. Den sistnevnte forståelsen kan være et forsøk på å utvide profesjonsbegrepet til å omfatte flere yrkesgrupper som tradisjonelt faller utenfor klassiske definisjoner av profesjon. Barnevernspedagoger kan trolig plasseres innenfor denne gruppen, da de ikke ivaretar kravet om offentlig autorisasjon. Barnevernspedagog omtales ofte som en semiprofesjon, mens sykepleier defineres som en egen profesjon.

Utfordringer $\mathrm{i}$ et handlingsrom for tverrfaglig samarbeid kan preges av at profesjoner og semiprofesjoner forankret i ulike ontologier har forskjellig innflytelse i samhandlingen, det vil si at kunnskapen er ordnet hierarkisk (K. Martinsen \& Boge, 2008). Innenfor både sykepleie og barnevern er evidensbasert kunnskap rangert høyt i kunnskapshierarkiet (K. Martinsen \& Boge, 2008; Bjørnebekk, 2010). Det er derfor mulig at tjenesteutøvere tilhørende profesjoner og semiprofesjoner som ivaretar evidensbasert kunnskap, kan tilegne seg definisjonsmakt i tverrfaglig samarbeid. Deres eventuelle situasjonsdefinisjon (Goffman, 2009) kan bidra til at bestemte former for målbar kunnskap løftes frem som mer evident eller «sann», og derved som viktigere enn kunnskap forankret i en humanistisk ontologi. Utøvelse av både sykepleie og barneverntjenester foregår ofte i komplekse situasjoner der behovet for profesjonserfaringer og brukerkunnskap er sentralt. Oppmerksomhet på evidensbasert kunnskap utfordrer imidlertid den mer helhetlige situasjonsanskuelsen som trolig er påkrevet for å fange situasjonenes kompleksitet. Det er mulig at økt oppmerksomhet på kunnskapsbasert praksis i tjenestene kan åpne opp det tverrfaglige handlingsrommet slik at ulike kunnskapsformer blir betraktet som likeverdige og utfyllende. Et tverrfaglig samarbeid som lykkes, kjennetegnes av at deltakerne er bevisst egen avhengighet av andres kunnskaper for å få til et helhetlig tjenestetilbud (Tingvoll \& Fredriksen, 2011). Økt bevissthet hos tjenesteutøvere er imidlertid ikke tilstrekkelig for å få til tverrfaglig samarbeid, fordi kontinuitet i samarbeidet mellom spesialistnivå og kommunalt nivå samt mellom ulike kommunale tjenester også utfordres av ressurs- og kompeansemangel i helse- og barneverntjenestene (Kassah, Tingvoll \& Fredriksen, 2014; Kassah, Tingvoll 
\& Nordahl-Pedersen, 2016). Diskusjonen tyder på at hvis profesjonstilhørighet og kunnskapshierarkiet bidrar til å tilsløre situasjonsavhengige kunnskapsbehov, kan mulighetene for å ivareta et helhetlig tjenestetilbud forringes (K. Martinsen, 2005; Eriksson, Myllymäki \& Nordman, 2002). Et tenkt eksempel på dette kan være hvis en leges handlingsrett og den medisinske kunnskapen blir bestemmende i en situasjon der det skal avgjøres om en kronisk nevrologisk syk pasient skal få innlagt PEGsonde (for å tilføre pasienten ernæring direkte i magesekken) eller ikke. Legen tar beslutningen uavhengig av kunnskapen som ansvarlig sykepleier innehar om pasientens situasjonsbetingede behov, noe som kan tilsløre andre mulige tiltak for å imøtekomme pasientens behov. Det er også mulig at den svake brukerinvolveringen som tjenesteutøvere både i kommunale helse- og omsorgstjenester og barnevern blir kritisert for, henger sammen med et dominant naturvitenskapelig kunnskapssyn i kunnskapshierarkiet og den evidensbaserte kunnskapens sentrale plass i både utrednings-, beslutnings- og implementeringsprosesser (Mørch, 2012).

Utfordringer knyttet til profesjonsutøvelse og tverrfaglig samarbeid kan også ha sammenheng med verdier og normer i den enkeltes tjenestens formelle og uformelle organisasjonsstruktur (Selznick, 1984). Endringer i formell organisasjonsstruktur kan for eksempel omfatte det at ledere arbeider med ansattes holdninger for å åpne opp for konstruktive tverrfaglige samarbeidsrelasjoner. Dette er tidkrevende og utfordrende endringsprosesser fordi holdninger kan ses på som konkretisering av verdier. Ifølge Martinussen (2008) har holdninger en kognitiv dimensjon og en affektiv komponent som forteller om den virkelighetsforståelsen holdningene bygger på. En tredje komponent som er knyttet til atferd, forteller noe om forholdet mellom holdning og handling (Martinussen, 2008). Holdninger fungerer som «veikart» for handlingsvalg og gir trygghet i en arbeidshverdag (Schiefloe, 2003), og endringer innebærer resosialisering og den utryggheten dette medfører før eventuelle holdningsendringer fremkommer. Samtidig er dype strukturelle organisasjonsendringer utfordrende fordi det også vil være behov for å implementere organisatoriske systemer og rutiner (Argyris, 1990) som kan styrke den informative og administrative kontinuiteten i det tverrfaglige samarbeidet 
(Freeman et al., 2007). Det kan imidlertid også være nødvendig å rette oppmerksomheten mot hvordan uformell struktur i kommunal helse- og omsorgstjeneste samt barnevern kan fremme eller begrense potensialet for tverrfaglig samarbeid. Endringer i formelle og uformelle strukturer, og derigjennom endringer i handlingsrommet for tverrfaglig samarbeid, kan være nødvendig for å gi et helhetlig tjenestetilbud.

Et tverrfaglig samarbeid der tjenesteutøvernes kunnskapsbidrag utgjør et fundament for prioriteringer og beslutninger, reflekterer en felles forståelse av pasienters og brukeres tjenestebehov og dermed også er avgjørende for tilbud som gis, kan trolig betraktes som et velfungerende samarbeid. I et slikt fundament ligger det trolig et potensial for utvikling av tiltak, løsninger og arbeidsformer som ikke har vært synlige i den enkelte profesjonens og semiprofesjonens perspektiv. Det skapes med andre ord handlingsrom for å utvikle ny kunnskap som omfatter flere dimensjoner ved et fenomen, det skapes en felles viten som her omtales som medviten. Dette er en form for viten som strekker seg ut over det enkelte fagets kunnskapsforståelse.

\section{Avsluttende kommentar}

Tverrfaglig samarbeid i kommunal helse- og omsorgstjeneste samt kommunalt barnevern møter mange utfordringer. I dette kapitlet er det spesielt grepet fatt i utfordringer knyttet til profesjonenes og semiprofesjonens faglige sammensetninger som bringer frem brytninger mellom kunnskap forankret i ulike ontologiske og epistemologiske retninger. Utfordringer knyttet til ulike ontologisk ståsteder ser ut til å skape spenninger også i tjenesteutøvelsen innenfor den enkelte profesjon og semiprofesjon. Spenninger både internt og i eksternt tverrfaglig samarbeid kan også aktualisere et kunnskapshierarki som muligens bidrar til å tilsløre eller hindre utvikling av helhetlige tjenestetilbud. Diskusjonen viser også at handlingsrommet for brukermedvirkning er begrenset i begge tjenestene, noe som krever økt oppmerksomhet i tverrfaglig arbeid.

Gjennomgangen av forskning og vår diskusjon viser at det er behov for forskning om hvilke endringer som kreves på organisatorisk nivå for å realisere tverrfaglig samarbeids potensial for å utvikle merviten som 
ivaretar et helhetlig tjenestetilbud. Det er samtidig behov for å forske mer på hvordan utdanningene i de ulike fagene kan styrkes, slik at yrkesutøverne kan utvikle åpenhet og forståelse for at det er behov for merviten når hver enkelt tjenestemottaker skal ivaretas.

Til slutt påpekes det at offentlige myndigheters søkelys på tverrfaglig samarbeid og samhandling som arbeidsform for å redusere ressursbruk og samtidig styrke et helhetlig tjenestetilbud er prisverdig. Offentlige føringers manglende problematisering av hvordan tverrfaglig samarbeid faktisk kan realiseres, samtidig som definisjoner av begrepene er både ulne og mangfoldige, gjør det vanskelig å finne retning for hvordan tverrfaglig samarbeid kan etableres og videreføres for å utvikle merviten. Dette blir kanskje spesielt synlig i kommunalt barnevern, der taushetsplikten, et formelt grunnlag, ofte blir et hinder for tverrfaglig samarbeid.

\section{Referanser}

Aadland, E. (2011). «Og eg ser på deg ...»Vitenskapsteori i helse- og sosialfag (3. utg.). Oslo, Universitetsforlaget.

Argyris, C. (1990). Overcoming organizational defences: Facilitating organizational learning. Boston, MA: Pearson.

Askheim, O. P. (2007). Empowerment - ulike tilnærminger. I O. P. Askheim \& B. Starrin (Red.), Empowerment i teori og praksis (s. 23-33). Oslo: Gyldendal Akademisk.

Baklien, B. (2009). Skole, barnehage, barneverntjeneste - bilder av «de andre» hindrer samarbeid. Tidsskriftet Norges barnevern, 86(4), 236-244.

Barne- og likestillingsdepartementet. (2017). Endringer i barnevernloven (barnevernsreform) (Prop. 73L (2016-2017)). Hentet fra https://www.regjeringen.no

Benner, P. \& Wrubel, J. (2001). Omsorgens betydning i sygepleje. Stress og mestring ved sundhed og sygdom. København: Munksgaard.

Berger, P. L. og Luckmann, T. (1966). Den samfundsskabte virkelighed: En videnssociologisk afhandling. København: Lindhardt og Ringhof.

Bjørnebekk, W. (2010). Utfordringer for utviklingen av et kunnskapsbasert barnevern. Hva barnevernjournaler forteller om skjønn, kunnskapssyn og faglig autoritet. Fontene forskning, 1, 91-103.

Breimo, J. P., Lo, C., Anvik, C. H. \& Sandvin, J. T. (2019). Mål og mening med samarbeid - en analyse av barnevernets formaliserte samarbeidsnettverk. Fontene forskning, 12(2), 4-17. 
Blaikie, N. (2003). Analyzing qualitative data. From description to explanation. Thousand Oaks, CA: SAGE Publications.

Christiansen, Ø. (2012). Hvorfor har barnevernet problemer med å se og behandle barn som aktører? Tidsskriftet Norges barnevern, 89(1-2), 16-30.

Collin, K. M., Valleala, U. M., Herranen, S. \& Paloniemi, S. (2011). Ways of interprofessional collaboration and learning in emergence work. Studies in Continuing Education, 34(3), 1-20.

Deloitte. (2019). Forsøk med ny ansvarsfordeling mellom stat og kommune på barnevernområdet (Delrapport 4). Hentet fra https://www.regjeringen.no/ contentassets/b87f5a6boeo5436587c911od2ae75884/folgeevaluering-av-forsokmed-ny-ansvarsfordeling-pa-barnevernomradet_endelig-rapport-01102019.pdf

Engelstad, F. (2009). Hva er makt? Oslo: Universitetsforlaget.

Eriksen, E. O. \& Molander, A. (2008). Profesjon, rett og politikk. I A. Molander \& L. I. Terum (Red.), Profesjonsstudier (s. 161-178). Oslo: Universitetsforlaget.

Eriksson, K., Myllymäki, I. \& Nordman, T. (2002). Den trojanske hest: evidensbasering og sygepleje. København: Gads Forlag.

Fauske, H., Kvaran, I. \& Lichtwarck, W. (2017). Hjelpetiltak i barnevernet Komplekse problemer og usikre virkninger. Fontene forskning, 2(10), 45-58.

Flaten, B., Brustad, M. S., Svendsen, H. \& Gjevre, M. (2013). Tverrfaglig samarbeid i barnevernsaker. Sykepleien, 101(6), 46-49. https://doi.org/10.4220/Sykepleiens 2013.0054

Fossum, S., Lauritzen, C., Vis, S. A. M., Ottosen, A. \& Rustad, K. B. (2015). Samhandling mellom barnevern og psykisk helsevern for barn og unge - en litteraturgjennomgang. Tidsskriftet Norges barnevern, 92(4), 282-297.

Foucault, M. (1991). Galskapens historie. Oslo: Gyldendal.

Fredriksen, S. T. D. (2011). Intensivpasientens gåtefulle kunnskap - om erfart kunnskap og kunnskapsformidling i en intensivkontekst (Doktorgradsavhandling). Nordiska högskolan för folkhälsovetenskap, Göteborg.

Freeman, G. K., Woloshynowych, M., Baker, R., Boulton, M., Guthrie, B., ... Tarrant, C. (2007). Continuity of care 2006; what have we learned since 2000 and what are policy imperatives now? (Rapport for National Co-ordinating Center for NHS Service Delivery and Organisation R \& D NCCSDO). Hentet fra http://www. netscc.ac.uk/hsdr/files/project/SDO_FR_08-1609-138_Vo1.pdf

Glavin, K. \& Erdal, B. (2013). Tverrfaglig samarbeid i praksis - til beste for barn og unge i Kommune-Norge (3. utg.). Oslo: Kommuneforlaget.

Goffman, E. (1992) Vårt rollespill til daglig. En studie i hverdagslivets dramatikk. Oslo: Pax.

Goffman, E. (2009). Stigma. Om afvigerens sociale identitet. København: Samfundslitteratur. 
Graverholt, B., Jamtvedt, G., Nordheim, L. V., Nortvedt, M. W. \& Reinar, L. M. (2012). Jobb kunnskapsbasert! En arbeidsbok. Oslo: Cappelen Damm.

Grimen, H. (2008). Profesjon og kunnskap. I A. Molander \& L. I. Terum, L. I. (Red), Profesjonsstudier (s. 71-86). Oslo: Universitetsforlaget.

Guneriussen, W. (1996). Aktør, handling og struktur: grunnlagsproblemer i samfunnsvitenskapene. Oslo: Tano.

Gulbrandsen, L. M., Seim, S. \& Ulvik, O. S. (2016). Barns rett til deltakelse i barnevernet: Samspill og meningsarbeid. Sosiologi i dag, 46(3-4), 54-78.

Helse- og omsorgsdepartementet. (2006). Nasjonal helseplan 2007-2010 (Særtrykk av St.prp. nr. 1 (2006-2007) kapittel 6). Hentet fra https://www.regjeringen.no/ globalassets/upload/hod/sykehus/nasjonal_helseplan_sartrykk.pdf

Helse- og omsorgsdepartementet. (2009). Samhandlingsreformen - Rett behandling - på rett sted - til rett tid (St.meld. nr. 47 (2008-2009). Hentet fra https://www. regjeringen.no

Helse- og omsorgsdepartementet. (2012). Se meg! - alkohol - narkotika - doping (Meld. St. 30 (2011-2012). Hentet fra https://www.regjeringen.no

Helse- og omsorgsdepartementet. (2014). Kvalitet og pasientsikkerhet 2013 (Meld. St. 11 (2014-2015). Hentet fra https://www.regjeringen.no

Helse- og omsorgsdepartementet. (2015a). Fremtidens primorhelsetjeneste - norhet og helhet (Meld. St. 26 (2014-2015)). Hentet fra https://www.regjeringen.no

Helse- og omsorgsdepartementet. (2015b). Kvalitet og pasientsikkerhet 2014 (Meld. St. 12 (2015-2016)). Hentet fra https://www.regjeringen.no

Helse- og omsorgsdepartementet. (2016). Kvalitet og pasientsikkerhet 2015 (Meld. St. 13 (2016-2017)). Hentet fra https//www.regjeringen.no

Helse- og omsorgsdepartementet. (2020). Lindrende behandling og omsorg - Vi skal alle dø en dag. Men alle andre dager skal vi leve (Meld. St. 24 (2019-2020)). Hentet fra https://www.regjeringen.no

Jensen, G. (2016). Brukermedvirkning og maktutøvelse - ungdom som medspiller og motspiller i barnevernet. Tidsskriftet Norges barnevern, 93(3-4), 304-320. https://doi.org/10.18261/issn.1891-1838-2016-03-04-13

Kassah, B. L. L., Tingvoll, W.-A. \& Fredriksen, S. T. D. (2014). Samhandling sykepleieledere og bestiller-utførerenhet. Geriatrisk sykepleie, 3, 26-33.

Kassah, B. L. L. \& Tønnessen, S. (2016). Samhandling i kommunale helse- og Omsorgstjenester - en studie hjemmesykepleieres erfaringer. Tidsskrift for velferdsforskning, 19(4), 342-358.

Kassah, B. L. L., Tingvoll, W.-A. og Nordahl-Pedersen, H. (2016). Folkehelsearbeid, sentrale utviklingstrekk. I B. L. L. Kassah, W.-A. Tingvoll \& H. NordahlPedersen, H. (Red.), Forebyggende helsearbeid. Sykepleie i kommunal helse- og omsorgstjeneste. Oslo: Gyldendal Akademisk. 
Forskrift om nasjonal retningslinje for sykepleierutdanning. (2019). Forskrift om nasjonal retningslinje for sykepleierutdanning (FOR-2019-03-15-412). Hentet fra https://lovdata.no/dokument/SF/forskrift/2019-03-15-412

Forskrift om nasjonal retningslinje for barnevernspedagogutdanning. (2019). Forskrift om nasjonal retningslinje for barnevernspedagogutdanning (FOR-201903-15-398). Hentet fra https://lovdata.no/dokument/LTI/forskrift/2019-03-15-398

Kvilhaugsvik, B. \& Husøy, B. (2017). Må samarbeide mer på tvers. Sykepleien, 105(3), 64-67. https://sykepleien.no/forskning/2017/02/ma-samarbeide-mer-pa-tvers

Lauvås, K. \& Lauvås, P. (2004). Tverrfaglig samarbeid - perspektiv og strategi (2. utg.). Oslo: Universitetsforlaget.

Martinsen, K. (2005). Samtalen, skjønnet og evidensen. Oslo: Akribe.

Martinsen, K. \& Boge, J. H. (2008). Kunnskapshierarkiet i evidensbasert sykepleie. Forum for akademiske sygeplejersker i Danmark, 3, 32-37.

Martinsen, J. T. (2012). Et kritisk blikk på evidensbaseringen i det statlige barnevernet: - Hva virker og hvorfor? Tidsskriftet Norges barnevern, 89(1-2), $58-69$.

Martinussen, W. (2008). Samfunnsliv. Innføring i sosiologisk tenkemåter (2. utg.). Oslo: Universitetsforlaget.

May, T. (2001). Social Research. Issues, methods and process (3. utg.). Buckingham, England: Open University Press.

Mørch, W.-T. (2012). Implementering av evidensbasesrte tiltak i barnevernet. Tidsskriftet Norges barnevern, 89(3), 136-150.

Nonaka, I. \& Takeuchi, H. (1995). The knowledge creating company: How Japanese companies create the dynamics of innovation. New York: Oxford University Press.

Nortvedt, P. (2008a). Profesjon og paternalisme. I A. Molander, A. \& L. I. Terum (Red.), Profesjonsstudier (s. 251-26o). Oslo: Universitetsforlaget.

Nortvedt, P. (2008b). Sykepleiens grunnlag. Historie, fag og etikk (2. utg.). Oslo: Universitetsforlaget.

Orvik, A. (2015). Organisatorisk kompetanse. Innføring i profesjonskunnskap og klinisk ledelse. Oslo: Cappelen Damm Akademisk.

Parsons, T. (1951). The social system. London, England: Routledge \& Kegan Paul.

Paulsen, V. (2016). Ungdommers erfaringer med medvirkning i barnevernet. Fontene forskning, 9(1), 4-15.

Polanyi, M. (1967): The tacit dimention. New York: Doubleday Anchor.

Røsdal, T., Nesje, K., Aamodt, P. O., Larsen, E. \& Tellmann, S. M. (2017). Kompetanse $i$ den kommunale barnevernstjenesten (NIFU-rapport 28/2017). Hentet fra https://nifu.brage.unit.no/nifu-xmlui/bitstream/handle/1125o/2487943/ NIFUrapport2017-28\%20.pdf? sequence $=1$ \&isAllowed $=\mathrm{y}$

Sandbæk, M. (2002). Barn og foreldre som sosiale aktører i møte med hjelpetjenester (Doktoravhandling). Norges teknisk-naturvitenskapelige universitet, Trondheim. 
Schiefloe, P. M. (2003). Mennesker og samfunn. Bergen: Fagbokforlaget.

Schutz, A. (1970). On phenomenology and social relations. Chicago, IL: University of Chicago Press.

Selznick, P. (1984). Leadership in administration: A sociologicel interpretation.

Oakland, CA: University of California Press.

Skivenes, M. (2015). Handlingsrommet for barns deltagelse i barnevernssaker. Tidsskrift for velferdsforskning, 18(1), 48-60.

Strandbu, A. \& Vis, S. A. (2008). Barns deltagelse i barnevernssaker. Barnevernets utviklingssenter i Nord-Norge. Tromsø: Barnevernets Utviklingssenter i NordNorge.

Støkken, A. M. (2014). Innovasjon i velferdstjenester. Innovasjon og utvikling $i$ sosialt arbeid. Bergen: Fagbokforlaget.

Thisted, J. (1990). Den videnskabelige krise i sundhedsvæsenet. Om den biomedicinske modell og helhedstænkning. I T. Jensen, L. U. Jensen \& W. Kim (Red.), Sykepleiens grunnproblemer. Etikk, vitenskapsteori, ledelse og samfunn. Oslo: Ad Notam Gyldendal.

Thrana, H. M. (2008). Vil jeg bestemme? Om barn og ungdoms medvirkning. Oslo: Gyldendal Akademisk.

Thrana, H. M. (2014). Kjærlighet - en anerkjennelsesrelasjon i arbeid med utsatt ungdom. Fontene forskning, 7(1), 4-17.

Tingvoll, W.-A. \& Fredriksen, S. T. D. (2011). Individuell tilretteleggelse for eldre pasienter etter sykehusopphold. Vård $i$ Norden, 3, 40-44.

Tønnessen, S. (2011). The challenge to provide sound and diligent care. A qualitative study of nurses' decisions about prioritization and patients' experiences of the home nursing service (Doktoravhandling). Universitetet i Oslo, Oslo.

Ugreninov, E., Vedeler, J. S., Heggebø, K. \& Gjevjon, E. R. (2017). Konsekvenser av sykepleiermangel $i$ kommunene fra et pasient- og pårørendeperspektiv (NOVA Rapport 7/17). Oslo: Norsk institutt for forskning om oppvekst, velferd og aldring.

Verdens helseorganisasjon. (2010). Framework for action on interprofessional education \& collaborative practice (Rapport). Hentet fra https://apps. who.int/iris/bitstream/handle/10665/70185/WHO_HRH_HPN_10.3_eng. pdf;jsessionid $=546 \mathrm{~A}_{66} \mathrm{~A}_{43} \mathrm{OAFE} \mathrm{CDB}_{77} \mathrm{FBC}_{22} \mathrm{Bo1}_{5927}$ ? sequence $=1$

Vik, E. (2018). Helseprofesjoners samhandling - en litteraturstudie, Tidsskrift for velferdsforskning, 21(2), 119-147.

Weber, M. (2000). Makt og byråkrati. (3. utg.). Oslo: Fakkel.

Wettergren, J., Ekornrud, T. \& Abrahamsen, D. (2019). Eldrebølgen legger press på flere omsorgstjenester i kommunen. Hentet fra https://www.ssb.no/helse/ artikler-og-publikasjoner/eldrebolgen-legger-press-pa-flere-omsorgstjenester-ikommunen 



\title{
KAPITTEL 3
}

\section{Sjuksköterskans kärnkompetenser}

\section{Lena Wiklund Gustin}

UiT Norges arktiske universitet och Mälardalens högskola, Sverige

\begin{abstract}
The overall aim of this chapter is to introduce different competencies that are considered as pivotal for good nursing care. This is motivated as skilfulness in such competences can contribute to how professionals manage their responsibilities and take actions as professionals. Therefore, the chapter is not presented as a study. Rather, it has a theoretical approach focusing on the description of six core competencies in nursing, i.e., patient-centred care, teamwork and collaboration, evidence-based practice, quality improvement, safety, and informatics. These core competencies have been developed and described by the QSEN Institute (Quality and Safety Education for Nurses). Therefore, they are reflected on in relation to an understanding of nursing as an autonomous profession with a theoretical basis in caring science. This will not only shed light on nurses' competencies but also contribute insights into the understanding of challenges and opportunities related to nurses' domains of actions.
\end{abstract}

Keywords: caring science, core-competencies, nursing, nursing values, professional responsibility

\section{Introduktion}

För att vården ska bli säker och hålla en hög kvalitet behöver kunskap omsättas i handling. Ett sätt att närma sig detta är att reflektera över vilka kompetenser en profession behöver ha för kunna göra det. I den reflektionen kan de kompetensområden som identifierats inom ramen för ett amerikanskt projekt, Quality and Safety Education in Nursing (QSEN) i USA, utgöra ett stöd. De sex kompetensområdena som stödjer och berikar varandra är: personcentrerad vård, samarbete i team, evidensbaserad

Sitering av denne artikkelen: Wiklund Gustin, L. (2020). Sjuksköterskans kärnkompetenser. I B. L. L. Kassah, H. Nordahl-Pedersen \& W.-A. Tingvoll (Red.), Handlingsrom for profesjonalisert velferd: Kommunale tjenester for helse, omsorg og barnevern (Kap. 3, s. 47-77). Oslo: Cappelen Damm Akademisk. https://doi.org/10.23865/noasp.114.ch3

Lisens: CC-BY 4.o. 
vård, förbättringskunskap för kvalitetsutveckling, informatik samt säker vård (Sherwood \& Barnsteiner, 2012). Tankegångarna har sedan spridits till andra länder. I ett skandinaviskt perspektiv har sjuksköterskans kompetensområden bland annat lyfts fram av Svensk sjuksköterskeförening (2010) och en svensk statlig utredning (SOU 2018:77) som betonar vikten av att samtliga kompetensområden beaktas i sjuksköterskeutbildningar på grund- och avancerad nivå. I Sverige har också ett flertal författare skrivit om dessa centrala områden för sjuksköterskans kompetens (Edberg et al., 2013; Leksell \& Lepp, 2013), men i Norge är litteraturen mer sparsam. Därför handlar det här kapitlet om de sex kompetensområdena och den betydelse de har för sjuksköterskors professionsutövning. I och med det berörs också sjuksköterskors handlingsutrymme, eftersom kompetensområdena inte bara återspeglar de krav och förväntningar som ställs på professionen. Sjuksköterskors användning av dessa kompetenser påverkas också av begränsningar relaterade till de ramar som finns i den kliniska verksamheten, något som har betydelse för de val och möjligheter som sjuksköterskor ställs inför i den kliniska vardagen.

Samtidigt som dessa kompetenser utvecklats i relation till sjuksköterskans profession så är de en angelägenhet även för andra personalgrupper inom vård och omsorg, exempelvis läkare, fysioterapeuter och psykologer inom olika kontexter. Exempelvis lyfter såväl internationella som nationella källor (Helsedirektoratet, 2018; Hoffmann, Bennett \& Del Mar, 2017; WHO, 2017) fram värdet av att olika yrkesgrupper baserar sina interventioner på en bedömning av den enskilde personens behov i relation till den vetenskapliga evidens som finns att tillgå inom området.

De som ansvarar för vården av patienter bör även ha kompetens nog för att bedriva säker vård, kunna identifiera brister och utvecklingsområden samt arbeta tillsammans. I dagens vård och omsorg ökar också kraven på att behärska informatik och olika former av hälso- och sjukvårdsteknologi (Nelson \& Staggers, 2018). Därför syftar detta kapitel till att introducera och reflektera över de sex kompetensområden som uppfattas som avgörande för god omvårdnad för att på så vis skapa en teoretisk förståelse för hur olika kompetensområden kan ha betydelse för de professionellas handlingsutrymme. Samtidigt som utgångspunkten tas i sjuksköterskeyrket som en autonom profession och således kan 
bidra med en teoretisk förståelse av sjuksköterskors kompetens, och av de utmaningar och möjligheter som är knutna till den och som bidrar till att forma sjuksköterskornas handlingsutrymme, är det rimligt att anta att dessa kompetensområden är aktuella inom andra professioner, även om ansvarsområdet skiljer sig åt. Detta betonas också av Leonardsen (2019) som beskriver värdet av att kartlägga den kompetens olika yrkesgrupper har för att säkerställa god kvalitet i en allt mer komplex kommunal vård och omsorg. I linje med exempelvis Gadamers (1989) tankar om att vi kan tillägna oss en ny förståelse genom att den egna förståelsehorisonten ställs i ett dialektiskt förhållande till en annan horisont, bör således läsare med en annan yrkesbakgrund än sjuksköterskor också få stöd av texten i en reflektion i relation till den egna professionens kompetens, ansvar och handlingsutrymme.

\section{Att ha en autonom profession}

Att vara sjuksköterska innebär att ha ansvar för andra människors liv och hälsa och att bära det ansvaret på ett professionellt vis. För att förstå sjuksköterskans handlingsutrymme behöver de krav och förväntningar som ställs på professionen synliggöras, något som är nära förknippat med den kompetens sjuksköterskor förväntas ha som utgångspunkt för sitt handlande. För att ett yrke ska få kallas profession behöver följande kriterier vara uppfyllda: Yrkets ansvar och verksamhet vilar på vetenskaplig grund i form av ett eget kunskapsområde, följer etiska regler samt att utbildningen leder fram till en auktorisation. Dessutom ska professionen vara autonom, värderas högt av samhället och tillhöra en nationell organisation (Svensk sjuksköterskeförening, 2016a).

Vårdvetenskap med inriktning mot omvårdnad utgör den vetenskapliga grunden för sjuksköterskans profession. Inom vårdvetenskap har olika forskare och teoretiker utvecklat en rad olika omvårdnadsteorier (Alligood, 2018; Kirkevold \& Bonnevie, 2010; Meleis, 2018; Wiklund Gustin \& Lindwall, 2012). Merparten av dessa är från USA, men i Norge har Kari Martinsen utvecklat en teori eller snarare en filosofi för en värdebaserad omvårdnad, som också uppmärksammats internationellt (Alvsvåg, 2018). Det utesluter inte att man som sjuksköterska också 
behöver använda sig av teorier från andra vetenskaper, som exempelvis medicin, psykologi och sociologi - det är en del av yrkesutövningen och den breddning som finns mot såväl andra vetenskaper som samarbetet med andra professioner. Men utgångspunkten för sjuksköterskans professionsansvar är den egna vetenskapen och dess teorier, vilket bland annat innebär att det är dessa som behöver omsättas i handling.

Ytterligare ett kriterium för en profession är att den följer etiska regler. I tillägg till de generella etiska principer som bör genomsyra all vård- och omsorgsverksamhet finns också en etisk kod för sjuksköterskor. Den är framtagen av International Council of Nurses (ICN, 2012) och återspeglas också i de nationella etiska riktlinjerna där det personliga och professionella ansvaret synliggörs (Norsk sykepleierforbund, 2019). Den etiska koden innebär bland annat att sjuksköterskor har ett ansvar att lindra lidande och främja hälsa, att visa respekt för patienters värdighet och autonomi samt värna om patienters sårbarhet och föra deras talan. Mot denna bakgrund har centrala etiska värden identifierats (National League for Nursing, 2020; Svensk Sjuksköterskeförening, 2016b). Sådana värden, som människovärde, självbestämmande, likabehandling, social trygghet, förutsägbarhet, öppenhet, rättvis fördelning av välfärd och rättssäkerhet ses också som grundläggande för den norska välfärdsstaten (NOU 2018:16).

För att man ska veta vad man kan förvänta sig av en sjuksköterska är utbildningen reglerad och leder till auktorisation i form av legitimation som sjuksköterska. Detta har betydelse för professionens autonomi, och därmed också för handlingsfriheten. Hummelvoll (1993) beskriver autonomi som att personen är fri och har kraft och förmåga att göra val och handla i enlighet med det han eller hon värderar. För sjuksköterskor handlar detta om att ha såväl frihet som förmåga att göra bedömningar och prioriteringar inom ramen för sitt ansvarsområde, och att ha vilja och mod att handla i linje med den kunskap och den värdegrund som professionen vilar på.

Förutsatt att professionen lever upp till det ansvar som är förknippat med den, skapas också förtroende och tillit så att sjuksköterskor också värderas i samhället. ICN, som utvecklat den etiska koden, är en sammanslutning av sjuksköterskeorganisationer från hela världen. Detta knyter an till det sista tecknet på en profession, att dess medlemmar är 
organiserade på nationell nivå, i Norge genom Norsk sykepleierforbund (NSF). Sammantaget kan vi således konstatera att det att tillhöra en profession innebär att ha ett ansvar, och med det en rad krav och förväntningar på att också ha en viss kompetens. Detta i sin tur bidrar till hur professionens handlingsutrymme formas.

\section{Sex kärnkompetenser i Quality and Safety Education in Nursing (QSEN)}

Som nämnts inledningsvis har QSEN (2019), vars övergripande mål är att förbereda blivande sjuksköterskor så att de har såväl de kunskaper och färdigheter som den hållning som behövs för att utveckla kvalitet och säkerhet inom det hälso- och sjukvårdssystem de arbetar inom, identifierat sex kompetensområden som är centrala för sjuksköterskors professionsutövande. Dessa områden är också kopplade till sjuksköterskans roll som ledare av omvårdnaden, något som innebär att sjuksköterskor behöver gedigen kunskap också om omvårdnadens värdegrund och bärande värden som exempelvis respekt för sårbarhet, värdighet och autonomi för att säkerställa en etisk vård (Buchanan-Barker, 2004; Cöster, 2003; Edvardsson, Watt \& Pearce, 2017; Gabrielsson, Sävenstedt \& Olsson, 2016; Nåden \& Eriksson, 2004; Pollard, 2015; Sarvimäki \& Sandelin Benkö, 2001; Svensk sjuksköterskeförening, 2016b).

\section{Personcentrerad vård}

Ett grundläggande värde inom omvårdnadsvetenskap är respekten för patientens värdighet. Därför framstår personcentrerad vård som det mest grundläggande kompetensområdet. Människan och hennes hälsa står i centrum för omvårdnaden, men fokus vidgas också mot att se personen i ett vidare sammanhang än den aktuella sjukdomssituationen. En sådan helhetssyn på människan är också utgångspunkt för de omvårdnadsteorier som utvecklats runt om i världen (Alligood, 2018; Kirkevold \& Bonnevie, 2010).

Den personcentrerade vården utgår från ett holistiskt perspektiv där den människa som är i behov av vård ses som en person snarare än att 
reduceras till att vara en patient med ett eller flera symtom som ska diagnosticeras och behandlas. Istället lyfter man fram en helhetssyn på människan som en person med vilja, förmågor och behov (Ekman, Norberg \& Swedberg, 2014). Att arbeta personcentrerat är därför ett sätt att tillämpa Ricoeurs (1992) "lilla etik", det vill säga att sträva efter det goda livet med och för andra inom rättvisa institutioner. Det "goda" är i detta fall att verka för den andres bästa och så långt det är möjligt tillsammans med denne, för att på så vis främja personens upplevelse av hälsa, eftersom hälsa i ett omvårdnadsteoretiskt sammanhang är en subjektiv erfarenhet som omfattar mer än frånvaro av sjukdom (Eriksson, 2018).

Två centrala begrepp $\mathrm{i}$ den personcentrerade vården är berättelsen och partnerskapet (Kristensson Uggla, 2014). Det blir med andra ord inte bara viktigt att "ha patienten i centrum" och ur ett expertperspektiv fastslå vad som är bäst för denne. Snarare måste utgångspunkten tas i personens berättelse, och en medvetenhet om att såväl sjuksköterskan som den vård patienten får - eller inte får - bidrar till denna berättelse. Därigenom blir också ett partnerskap med utgångspunkt i relationen som samtidigt asymmetrisk och ömsesidig central.

Personcentrerad vård innebär alltså att beakta personens perspektiv och livssammanhang och inte bara dennes ohälsoproblem, och att så långt det är möjligt ge patienten inflytande över omvårdnadsplanen. En professionell hållning innebär emellertid också att kunna se skillnad mellan det en person vill här och nu och det denne verkligen behöver och agera utgående från denna bedömning (Wiklund Gustin, 2019). En person som lider av diabetes kan till exempel önska sig mat som kan påverka hälsotillståndet negativt, och personer som utvecklat ett beroende av exempelvis smärtstillande eller ångestdämpande läkemedel kan mycket väl ge uttryck för en önskan om en ökad dosering. En "låt-gå"-attityd där personen får sin vilja igenom kan således innebära ett svek och en kränkning för patienten, i lika hög grad som rigida strukturer där man exempelvis tillämpar regler för deras egen skull (Bowen \& Mason, 2012). Det är emellertid viktigt att de gränser som sätts upp i form av regler utgår från patientens vårdbehov och inte från personalens behov av ordning och struktur (Enarsson, Sandman \& Hellzén, 2007). Kompetensen handlar med andra ord inte bara om att lindra lidande och hjälpa 
patienten att komma till rätta med ohälsoproblem. I grunden innebär det också att sjuksköterskan bör ha ett handlingsutrymme för att kunna använda den makt som är knuten till det professionella ansvaret för att främja patientens intressen med utgångspunkt i personens eget perspektiv och livssituation, snarare än för att styra patienten mot standardiserade mål för vad som är ett gott liv som definierats av hälso- och sjukvården (Wallinvirta, 2017). På svenska talar Rundqvist (2004) om detta som att sjuksköterskan har patientens fullmakt att agera å patientens vägnar när hen saknar kraft att göra det själv, medan engelskspråkig litteratur ofta använder begreppet "advocacy" (Gerber, 2018; McKeown et al., 2014). Begreppet som använts under flera decennier sträcker sig bortom patientens juridiska rättigheter och inkluderar även att sjuksköterskan ger röst åt patienten på ett sådant sätt att personens livssituation, värden och drömmar också får utrymme (Barker \& Buchanan-Barker, 2004; Gaylord \& Grace, 1995; Lindahl \& Sandman, 1998).

Det borde således vara självklart att som sjuksköterska alltid utgå från människan i ett helhetsperspektiv. En sådan holistisk syn på personen som en person som finns i ett sammanhang, och vars hälsa behöver förstås i relation till den övergripande livssituationen och inte reduceras till symtom, kan emellertid vara utmanande såväl i forskning som i den kliniska vardagen (Montgomery Dossey \& Keegan, 2013; Zahourek, 2009). Vården har blivit allt mer specialiserad, och organisatoriska modeller som exempelvis New public management (NPM) kan innebära att kraven på effektivitet och lönsamhet leder till att fokus läggs på specifika och avgränsade problem snarare än på att se personen och dennes hälsa i ett större sammanhang (George, 2017). Detta kan begränsa upplevelsen av handlingsfrihet, och i värsta fall också innebära att sjuksköterskor distanserar sig från de personer de vårdar. Därför är det viktigt att sjuksköterskor tillägnar sig omvårdnadsvetenskap och den värdegrund vetenskapen vilar på så att omvårdnaden blir personcentrerad på ett sådant sätt att patienten känner sig sedd och tillvaratagen som person (Barker, 2008; Martinsen, 2000). Detta är också i linje med sjuksköterskors etiska ansvar för de prioriteringar som görs i vården, så att resurser fördelas rättvist och sårbara personers behov och rättigheter tillgodoses (NOU 2018:16). 
Men är personcentrerad vård bara en sjuksköterskekompetens? Borde inte detta vara något för alla som arbetar inom vården? Förmodligen skulle många svara ja på den frågan, och kanske likt Sheard (2004) ställa frågan om inte begreppet "personcentrerad vård" bara är en ny benämning på något som existerat under en lång tid, men uttryckts med andra begrepp som exempelvis patientcentrerad vård eller primærsykepleie. Skillnaderna jämfört med patientcentrerad vård är emellertid inte bara semantiska (Barnett, 2018). Som en analys av tidigare reviewartiklar på begreppen personcentrerad respektive patientcentrerad vård visar finns det många likheter (Håkansson Eklund et al., 2019). Inom såväl den patient- som den personcentrerade vården betonas en helhetssyn och fokus på individen, liksom vikten av empati, engagemang, trygga relationer, delat beslutsfattande och samordnad vård. Håkansson Eklund med kolleger (2019) upptäckte emellertid också en intressant skillnad - dessa olika aspekter formades i relation till olika mål. Inom ramen för patientcentrerad vård fann de att empati, delat beslutsfattande etcetera var viktiga redskap för att nå mål som fokuserade på att patienten skulle få ett funktionellt liv. Inom ramen för personcentrerad vård konstaterade samma forskare att dessa redskap istället användes för att främja ett meningsfullt liv för personen.

Håkansson Eklund et al.:s (2019) översikt av forskning avseende patientrespektive personcentrerad vård visade således att den patientcentrerade vården inriktar sig mot funktionalitet och att patienten ska bli så frisk som möjligt, medan den personcentrerade vården - utan att förringa att såväl funktionalitet som friskhet är viktiga områden - i högre grad också beaktar möjligheten till ett meningsfullt liv för personen, oavsett funktionsnivå. Ett möjligt sätt att förstå denna skillnad är att omvårdnaden formas i relation till synen på människan som patient/person och den situation personen befinner sig i, men också i hur vi ser på hälsa. Inom personcentrerad vård ses hälsa, i linje med flertalet omvårdnadsteorier som beskrivs i böcker som Nursing Theorists and Their Work (Alligood, 2018) och Sykepleieteorier analyse og evaluering (Kirkevold \& Bonnevie, 2010) inte som ett objektivt tillstånd i motsats till att vara sjuk, utan som en subjektiv upplevelse av livet som meningsfullt och en själv som i stånd att hantera tillvarons utmaningar och förverkliga små och stora projekt i livet (Dahlberg \& Segesten, 2010; 
Ricoeur, 1992). Det kan till exempel handla om att trots sjukdom kunna göra sådant man upplever som meningsfullt, och att uppleva att man har sin värdighet intakt snarare än om att återfå funktion. Detta ska inte tolkas som att funktionalitet inte är viktigt, och för många professioner kan detta vara centralt. Samtidigt innebär det etiska utmaningar om målet med vården reduceras till funktionalitet eller till att en person ska bli frisk, eftersom människor som inte når detta mål inte får överges som "färdigbehandlade" eller "icke-behandlingsbara".

Personcentrerad vård kan med sin tydliga koppling till den syn på människan, hennes hälsa, livssituation och vård som med utgångspunkt i konsensusbegreppen ${ }^{1}$ beskrivs i omvårdnadsvetenskapliga teorier (Alligood, 2018; Kirkevold \& Bonnevie, 2010), ses som ett centralt kompetensområde för professionen. På samma sätt behöver den omvårdnadsvetenskapliga grunden genomsyra övriga kompetensområden för att professionens unika särart ska bli synlig.

\section{Samarbete i team}

Med utgångspunkt i personcentrerad vård kan ett team beskrivas i termer av "patient och/eller närstående i samverkan med professionell personal" (Ekman et al., 2014, s. 80). Teamsamverkan kan med andra ord inte begränsas till interprofessionellt samarbete för patientens bästa, utan är en fråga om att arbeta tillsammans med patienten och dennes närstående för att skapa ett bärkraftigt vardagsliv (Rusner, 2019). Detta innebär också att delaktighet sträcker sig längre än till att patienten är välinformerad och deltar i beslutsfattande och innefattar även att patienten känner sig inkluderad i en gemenskap (Eldh, 2006). De från den

1 I och med att omvårdnadsforskningen började växa fram enades forskare om att en omvårdnadsteori skulle beakta fyra begrepp som det rådde konsensus om skulle inkluderas i omvårdnadsteorier: människa/patient, hälsa, omvårdnad och miljö. Inom ramen för respektive teori gavs dessa s.k. konsensusbegrepp sedan innehåll och relaterades till varandra. Detta innebar paradigmatiska likheter som gav stöd för att utveckla omvårdnadsvetenskapen och skilja ut den från andra vetenskaper, samtidigt som det möjliggjorde analys av skillnader mellan teorier inom vetenskapen. Konsensusbegreppen kallas därför ibland även för omvårdnadens metaparadigm (Fawcett, 1980, 1996). 
personcentrerade vården centrala begreppen 'berättelsen' och 'partnerskapet' bör med andra ord genomsyra teamarbetet - såväl i relation till patientens och dennes närståendes delaktighet som mellan de professionella medlemmarna i teamet. Detta innebär att teamets medlemmar behöver vara medvetna om att de är medaktörer i såväl varandras som patienters och närståendes berättelser, och att det sätt vi agerar och möter varandra på har betydelse för hur de inblandade personerna ser på sig själva och sina möjligheter att både ge och få hjälp och att ta ansvar på ett sådant sätt att autonomi och värdighet främjas. Det innebär också att man ser på varandra - såväl professionella som patienter och deras närstående - som jämlika partner i det "projekt" som omvårdnaden av varje enskild patient innebär. Detta kan också jämföras med Lévinas (1988) tankar om att vi har ansvar för den andres ansvar, vilket bland annat innebär att ta det ansvar den andre i stunden inte förmår, och att också ge personen det ansvar hen kan bära - oavsett om personen är en kollega eller en patient - då detta enligt Lévinas är en mellanmänsklig process som bör genomsyra alla relationer.

Genom att tillvarata vars och ens kunnande kan olika professioner tillsammans med patienten forma en god vård och omsorg för dem som behöver den. Ett gott samarbetsklimat ska således inte förstås som att alla kan och vill exakt samma saker, utan om att var och en har tillräckligt stor handlingsfrihet för att ta sitt professionsansvar. Förmågan att samarbeta i team innebär därigenom också en möjlighet att vidga sitt handlingsutrymme i och med att man såväl kan synliggöra den egna professionens kunnande som hitta övergripande arbetssätt där detta kunnande kompletterar andras, snarare än att konkurrera med dem. Detta kan vara en utmaning, eftersom det många gånger medför förändringar i arbetssätt och strukturer. Om kulturen på en arbetsplats präglas av maktordningar där vissa yrkeskategorier tar sig mer makt eller ges tolkningsföreträde, eller där olika genusförhållanden avgör vems röst som blir hörd, kan det vara svårt att få till ett fungerande teamarbete (Ekstrand, 2010). En annan utmaning finns i hur vi använder språket. Som Håkansson Eklund et als. (2019) studie visade så kan vi inte ta för givet att vi talar om samma sak även då vi använder likartade begrepp. Sjuksköterskans kompetens innefattar här en medvetenhet om betydelsen av olika perspektiv och en 
förmåga att ta det omvårdnadsansvar som är förknippat med den egna professionen. Sjuksköterskor behöver således kunna artikulera och hävda den omvårdnadsvetenskapliga kunskapsbasen, och de bärande värden som är förknippade med professionen, samtidigt som de i dialog med andra synliggör personens perspektiv (Holm, 2014). Detta är nödvändigt för att inte förlora sin etiska integritet.

Sjuksköterskor kan därigenom fylla en viktig roll för att koordinera vården med utgångspunkt $\mathrm{i}$ en helhetssyn på patientens situation och vårdbehov (Leonardsen, 2019; McKay \& Vanaskie, 2018; Neumann, Olsvold \& Thagaard, 2016; Ruggiero, Pratt \& Antonelli, 2019). Detta är viktigt, eftersom bristande koordination också innebär att vårdens kvalitet hotas (Grimsmo, Kirchhoff \& Aarsedt, 2015; Sundlisæter Skinner, 2015). Samtidigt kan sjuksköterskans roll i teamarbete således inte begränsas till att vara en samordnande "spindel i nätet", vilket är en liknelse som ofta används av sjuksköterskor när de ska beskriva sin funktion relaterat till teamets arbete (Lindberg-Sand, 1996). Snarare än att koordinera andra yrkeskategoriers insatser handlar det om att bidra med sin omvårdnadskompetens på en nivå som är jämbördig med övriga teammedlemmars (Carlström, Kvarnström \& Sandberg, 2013). På det viset kan samarbetet leda till vinster inte bara för patienten utan också för teamets medlemmar. Sandberg (2011) talar om detta i termer av samarbetshälsa och funktionella synergier som skapar gynnsamma förutsättningar för teamet att utvecklas. De förutsättningar Sandberg talar om är i hög grad interpersonella, samtidigt som det är viktigt att vara medveten om att arbetsformer och bristande yttre förutsättningar rent praktiskt kan försvåra teamets arbete. För att teamet ska fungera bra är det inte bara viktigt att ha en tilltro till varandra och till att det gemensamma arbetet är viktigt och meningsfullt. Det är också viktigt att förstå varandras roller, och hur olika roller i teamet kompletterar varandra, samt att ha förmågan att kommunicera på ett sådant vis att man kan omsätta visioner och beslut i handling, följa upp det man gör och hantera motsättningar och stress på ett konstruktivt vis (Baker, Day \& Salas, 2006). Detta är viktiga förmågor för teamets alla medlemmar, men teamet behöver också ett gott ledarskap. Ofta kan det vara sjuksköterskan som är ledare för teamet. Detta kräver generella ledaregenskaper men också kompetens i relation till det 
egna paradigmet, och att man kan vara autentisk i sitt ledarskap genom att i sin grundhållning sträva efter förståelse av den andres verklighet som en källa till kunskap (Akerjordet, 2014). Ledarskapet bör således präglas av att ledare lever som de lär (Bondas, 2006). Ett sådant ledarskap präglas inte bara av att ledaren har handlingsfrihet nog att trots ekonomiska och organisatoriska begränsningar verka för personcentrerad omvårdnad av hög kvalitet. Det kan också förstås i termer av styrkebaserat ledarskap, där ledaren även bidrar till att stärka medarbetares upplevelse av handlingsfrihet och tilltro till sin egen kompetens (Oljemark, 2014b).

\section{Evidensbaserad omvårdnad}

Internationellt talar man om evidensbaserad omvårdnad (evidence based nursing, EBN), medan man i Norge ofta använder begreppet kunskapsbaserad praxis. I grunden handlar ett evidensbaserat arbete om att vi ska göra det vi vet och kan (Willman, Bahtsevani, Nilsson \& Sandström, 2016).

Traditionellt värderas så kallade RCT-studier, d.v.s. randomiserade kontrollerade studier som designas med noga utvalda interventions- respektive kontrollgrupper, högt inom hälso- och sjukvården. Detta gestaltas tydligt i den så kallade evidenspyramiden där RCT-studier, experiment och stora kvantitativa studier rankas högst. Först på sjunde plats av åtta bland olika källor till evidens återfinns kvalitativa studier (Polit \& Beck, 2017). Att ranka RCT-studier högt är rimligt när det gäller att värdera effekten av specifika interventioner. Samtidigt behöver man vara medveten om att resultaten $\mathrm{i}$ dessa studier återspeglar hur verksamt något är på gruppnivå. I relation till personcentrerad vård och en syn på varje människa som unik kan det emellertid bli problematiskt om det enbart blir denna typ av forskning som styr vad som görs och inte görs på en enhet (Martinsen \& Eriksson, 2009). Därför har omvårdnadsforskare de senaste tjugo åren lyft fram att också kvalitativ forskning har ett värde och kan bidra till att såväl patienters och närståendes som de professionellas erfarenheter tas tillvara. Genom att ta del av den kan de professionella få en vidgad förståelsehorisont och i och med det också en nyanserad grund för handling (Clarke, 1999; Fawcett, Watson, Neuman, Hinton Walker 
\& Fitzpatrick, 2001; L. Fredriksson, 2014; French, 2002; Norlyk, Haahr, Dreyer \& Martinsen, 2017; van Wijngaarden, van det Meide \& Dahlberg, 2017). Detta innebär inte att positivistisk forskning är meningslös, men att den - i likhet med all forskning - behöver problematiseras eftersom ett för snävt evidensbegrepp och ett för stort fokus på standardiserade interventioner kan inkräkta på sjuksköterskans handlingsutrymme och möjligheter att bedriva personcentrerad omvårdnad. Det handlar om att granska kunskapens värde som grund för sjuksköterskans reflektion och handlande. På vilka grunder väljer sjuksköterskan att agera på det ena eller det andra sättet? Hur påverkas handlingsutrymmet om ett strikt evidensbegrepp tillämpas, jämfört med en kunskapsbaserad och personcentrerad vård där såväl kvalitativ forskning som patientens egna erfarenheter beaktas? Hur kan sjuksköterskan manövrera mellan generella riktlinjer och omsorg om personen utan att vården blir godtycklig?

Ett sätt att hantera spänningen mellan standardiserade metoder som baserar sig på kvantitativ forskning och sjuksköterskans ansvar för personcentrerad vård är att utgå från utvärderade metoder och att anpassa tillämpningen till den unika personen (Hellzén, Johansson \& Pejlert, 1999). Den kvantitativa forskningen kan också kompletteras med resultat från kvalitativa studier. För att utnyttja den kunskap som tagits fram i små, kvalitativa studier görs idag olika metastudier där flera kvalitativa studier som berör samma område syntetiseras. På så sätt skapas ett bredare underlag baserat på analys av subjektiva erfarenheter (Bondas \& Hall, 2007; Finfgeld, 2003; Sherwood, 1999). Ett annat sätt är att vidga evidensbegreppet så att det beaktar även andra former av kunskap. Det innebär att inte bara utgå från resultatet av vetenskapliga studier, utan också ta hänsyn till vårdares, patienters och närståendes erfarenheter av vad som fungerar inte bara i en viss situation, utan för en viss person (Karlsson \& Borg, 2017). En sådan syn på evidens kan stärka patientens autonomi, då den enskilde personens uppfattning om vad som är verksamt mycket väl kan vara annorlunda än det som är evident på en övergripande nivå (Colyer \& Kamath, 1999). Utifrån ett sådant perspektiv kan sjuksköterskor tillämpa kunskap på ett sätt som är evident i relation till den enskilda personens perspektiv och förena empirisk, etisk och praktisk kunskap (Eriksson, Nordman \& Myllimäki, 1999). 
Att arbeta kunskapsbaserat innebär därför inte att rutinmässigt följa exempelvis manualbaserade metoder för en viss typ av problematik. Snarare handlar det om att $\mathrm{i}$ vården av enskilda personer kunna integrera det man kan tala om som bästa tillgängliga vetenskapliga bevis med sin kliniska erfarenhet och patientens önskemål (Johansson \& Wallin, 2013). Detta innebär, som tidigare lyfts fram, att personens perspektiv på vad som är viktigt och verksamt måste beaktas. Det innebär dessutom att sjuksköterskan behöver ha de kunskaper som behövs för att - med utgångspunkt i en analys av patientens hälsa, ohälsa och omvårdnadsbehov - kunna söka och värdera tillgänglig forskning. Med denna som stöd kan sjuksköterskan prioritera evidensbaserade omvårdnadsinterventioner och utnyttja sitt handlingsutrymme till att tillämpa dem på ett sätt som kan beskrivas som vårdkonst (Nåden, 1998).

\section{Förbättringskunskap för kvalitetsutveckling}

I Svensk sjuksköterskeförenings och Svenska läkaresällskapets (2017) skrift om teamarbete och förbättringskunskap finns två citat av Paul B Batanden:"Alla som arbetar och kommer att arbeta i hälso- och sjukvården har två jobb: att göra det ordinarie arbetet och jobbet att utveckla detta arbete och system man arbetar i" (s. 23) och "Alla förändringar innebär inte förbättringar, men alla förbättringar innebär förändringar" (s. 28).

Citaten fångar dels den oundvikliga verklighet vårdpersonal lever $i$, en värld där kunskapen om vad som är det bästa att göra ständigt utvecklas, dels att förändring i sig inte har ett egenvärde - ska den vara meningsfull bör den leda till att den vård som ges får högre kvalitet. Detta lyfts också såväl av WHO som på nationell nivå (Helse- og omsorgsdepartementet, 2016) som prioriterade områden. I WHO:s (2020) definition relateras kvalitet till att vården är säker, evidensbaserad, kostnadseffektiv, jämlik och tar hänsyn till såväl personliga preferenser som kulturella faktorer. Det är därför inte förvånande att förbättringskunskap för kvalitetsutveckling har lyfts fram som ett centralt kompetensområde för sjuksköterskor.

Som sjuksköterska är man inte bara ansvarig för den omvårdnad man ger själv. Man förväntas också ha kompetens för att aktivt värna om omvårdnadens kvalitet, liksom om arbetsmiljö och resursutnyttjande. 
Det handlar om att ha kunskaper och färdigheter såväl för att bidra till större projekt där evidensbaserade metoder implementeras som att kunna arbeta med alla de små förändringar som kan behöva göras på en enhet eller i en organisation. Det förbättringsarbete som bedrivs, både vad gäller vårdens innehåll och metoder, har därmed också betydelse för sjuksköterskors handlingsutrymme i det direkta omvårdnadsarbetet, eftersom det bidrar till såväl ramar som förutsättningar.

Eftersom förbättringar bör vila på vetenskaplig grund samt beakta patienters och närståendes behov behöver sjuksköterskan vara uppdaterad i forskning och nationella riktlinjer samt ha en reflekterande hållning i relation till praxis (Gabrielsson \& Ejneborn Looi, 2019b; Johansson \& Wallin, 2013). Frågor som "Vad gör vi, och varför gör vi det?", "Utgår det vi gör från det vi vet, eller är det andra faktorer som avgör hur omvårdnaden utformas?", "Vad finns det för vetenskapligt stöd för det vi gör?" och "I vilken riktning bör vi utveckla det vi gör?" kan bidra till att identifiera utvecklingsområden. Andra resurser för att identifiera områden för kvalitetsutveckling är nationella kvalitetsregister. Hos Nasjonalt servicemiljø for medisinske kvalitetsregistre finns sådana inom en rad områden. ${ }^{2}$ Hommel, Idwall och Andersson (2013) lyfter också fram värdet av att använda sig av lokala enkäter, exempelvis patientnöjdhet eller avvikelserapporter för att på så vis identifiera områden för kvalitetsutveckling på den egna enheten. Dessutom är det viktigt med brukarmedverkan. Detta innebär inte bara att patienter bör vara delaktiga i sin egen vård och behandling, utan också ges möjlighet att påverka hur hälso- och sjukvården organiseras och görs delaktiga i forsknings- och utvecklingsprojekt (M. Fredriksson, Torjesen, Tynkkynen \& Vrangbæk, 2019; Grundy et al., 2016). I det direkta förändringsarbetet innebär brukarmedverkan också en möjlighet att värna om personcentrering, och det kan också bidra till en maktförskjutning där patienter känner sig tillvaratagna och respekterade samtidigt som de också kan få en ökad förståelse för hur vården fungerar (Socialstyrelsen, 2012).

När man identifierat potentiella utvecklingsområden behöver man som sjuksköterska kunna söka och granska vetenskapliga artiklar och ta fram underlag för kunskapsbaserad praxis samt ta en aktiv roll i

2 Se https://www.kvalitetsregistre.no/ 
implementeringen av denna kunskap. Implementering handlar om den process där kunskap - som förmodas innebära en lösning på det identifierade problemet - på ett aktivt och systematiskt vis integreras i praktiken. Detta ställer ytterligare krav på sjuksköterskors kompetens då det inte bara förutsätter vetenskaplig och metodisk kunskap i relation till den specifika förbättring som ska göras. För ett lyckat utvecklingsarbete behövs även medvetenhet om hur hälso- och sjukvårdssystem fungerar, kunskaper om förändringsprocesser samt förmåga att kommunicera och samverka i team (Ennis, Happell, Broadbent \& Reid-Searl, 2013).

Detta är ett kompetensområde som är angeläget för alla professionella inom hälso- och sjukvården, och sjuksköterskor förväntas ha de kunskaper och färdigheter som krävs för att ha en aktiv roll genom hela processen, såväl genom att identifiera hinder för förändring och möjliga vägar att övervinna dem som genom att utbilda personal utifrån det framtagna kunskapsunderlaget. Sjuksköterskan kan också vara en möjliggörare, både genom att vara modell och genom att stödja sina kolleger i tillämpningen av vetenskaplig kunskap (Johansson \& Wallin, 2013). Samtidigt kan detta också vara ett område där sjuksköterskor upplever att de har begränsad handlingsfrihet. Detta blir speciellt påtagligt om sjuksköterskor förväntas genomföra förändringar som de inte uppfattar som relevanta för god och säker vård (Mathieson, Grande \& Luker, 2019). Sådana "top-down"-förändringar kan också generera så kallad samvetsstress om vårdare upplever att det sätt vården är organiserad på utgör en begränsning i relation till de krav och förväntningar som är knutna till professionens grundläggande etiska värden och till det egna samvetet (Åhlin, 2015).

\section{Informatik}

De senaste decennierna har användandet av internet och datorer brett ut sig i samhället. I och med det har också informatik, d.v.s. informationsoch kommunikationsteknologi, blivit en del av vardagen inom hälso- och sjukvård. Informationsteknologin påverkar i allt högre grad hur vårdare och patienter kommunicerar med varandra och därmed också formerna för hur vård kan bedrivas. Så kallad "e-hälsa", ett område där bland annat 
telefonrådgivning, datorbaserade beslutssystem, videokonsultationer, elektroniska journaler och distansutbildningar av patienter och närstående lyfts fram, kommer med all sannolikhet att utvecklas i framtiden. Som Sävenstedt och Florin (2013) påpekar, så innebär det både utmaningar och möjligheter. Möjligheten att överföra och lagra information kan främja en god och säker vård genom att såväl dokumentation av omvårdnaden som kvalitetsuppföljning underlättas. Den nya tekniken skapar möjligheter för vård i hemmet, och innebär också en möjlighet för patienter till såväl informationssökande som till social interaktion (Spinzy, Nitzan, Becker, Bloch \& Fennig, 2012). Den allmänna debatt som gäller källkritik har därför sin plats inom detta område. För att vara säker på att den information man hämtar är evidensbaserad och har ett relevant innehåll kan de kriterier som satts upp av The Health On the Net Foundation (www.hon.ch/en/) vara till stöd.

En ökad grad av tekniska hjälpmedel och ett allt mer digitaliserat arbetssätt kan också skapa stress (Abuatiq, 2015; Stadin et al., 2016). Denna stress kan upplevas som något som inkräktar på sjuksköterskans handlingsfrihet och "stjäl" tid från den direkta patientkontakten. Samtidigt visar forskning att positiva erfarenheter av teknologin också kan bidra till att arbetsmiljön upplevs positivt (Koivunen, Kontio, Pitkänen, Katajisto \& Välomäki, 2013).

Trots att informatik kan föra tankarna till teknik och distans, är det även i dessa sammanhang viktigt att beakta personen. Informatiken ställer sjuksköterskan inför en etisk uppmaning, där patienten inte får reduceras till ett digitalt objekt. Speciellt utmanande kan det vara om man inte, som i en reell vårdsituation, ställs inför den andres ansikte (Birkler \& Dahl, 2014). Då finns en risk att fokus riktas mot informationsinhämtning och att personen därmed reduceras. Formatet kan också göra att information som exempelvis kroppshållning, dofter och annat som så att säga "faller utanför skärmen" missas. Användandet av informatik kräver således inte bara tekniska färdigheter utan också en reflekterande hållning hos sjuksköterskan. Rätt använd kan den då bli en tillgång, där information och kommunikation kan utvecklas (Martin, 2018; Sandelowski, 2000). Omvänt kan en bristande hantering, såväl vad gäller källkritik, sekretess som inkompatibla system, bidra till en negativ 
arbetsmiljö och till att vården inte blir etisk och patientsäker (Anderson, Frogner, Johns \& Reinhardt, 2006; Skär \& Söderberg, 2017).

Informatik är således ett brett område som innefattar allt från att dokumentation som tidigare skedde på papper digitaliseras till avancerade tekniska lösningar. Det är också ett område där den tekniska utvecklingen går snabbt. Kunskaper och färdigheter inom detta område är således färskvara, vilket innebär att sjuksköterskor behöver ha en beredskap för att sätta sig in i aktuella tekniska lösningar som finns i den verksamhet där de arbetar.

\section{Säker vård}

Ett av kännetecknen för en profession är att den värderas högt av samhället. En förutsättning för det är att den omvårdnad som ges är både av god kvalitet och säker. Därför är det inte överraskande att en av utgångspunkterna när sjuksköterskans centrala kompetensområden beskrevs var att vården skulle bli säkrare (Sherwood \& Barnsteiner, 2012). Det innebär att alla de kompetensområden som beskrivs i detta kapitel bidrar till en god och patientsäker vård, inte minst förbättringskunskap för kvalitetsutveckling. Detta syns inte minst på https://pasientsikkerhetsprogrammet.no där en rad olika områden för kvalitetsutveckling och säker vård beskrivs som har tydlig koppling till sjuksköterskors arbete, exempelvis läkemedelshantering på sjukhus och förebyggande av fallskador och sepsis. Emellertid behövs också specifik kompetens för att på ett direkt och medvetet sätt verka för att vården ska vara säker för såväl dem som vårdas som dem som arbetar där.

När vi talar om patientsäkerhet och säker vård är syftet att undvika och minska negativa händelser i form av vårdskador och komplikationer (Öhrn, 2013). Detta är angeläget eftersom det finns brister i vården och även risker för att skador uppkommer. Riskområden kan exempelvis vara relaterade till felaktigt handhavande av medicinsk-teknisk utrustning, men även till läkemedelsbiverkningar, bristande hygien och situationer där hot och våld förekommer och/eller till självskador och suicidalitet hos patienter. Andra områden där patientsäkerheten kan äventyras är informationsöverföring - såväl inom organisationen som till vårdgrannar. 
Med utgångspunkt i ett omvårdnadsvetenskapligt perspektiv och tanken om personcentrerad vård kan även händelser som kränker patientens värdighet eller på annat sätt skapar vårdlidande (jfr Eriksson, 2018) ses som patientosäkert, då denna typ av händelser inte gynnar patientens hälsoprocesser och kan leda till att patienten och dennes närstående känner sig otrygga med såväl personalen som den vård som ges.

Avvikelser och risksituationer kan inträffa genom att det görs misstag och felbedömningar i en situation, men de kan också bero på latenta förhållanden (Öhrn, 2013). De senare är relaterade till omgivande faktorer som exempelvis bristande rutiner eller utrustning.

Eftersom det kan vara svårt att skilja mellan skador som går att undvika och sådana som inte gör det är det alltid angeläget med reflektion när negativa händelser inträffat. Detta är emellertid inte tillräckligt det behövs också reflektion för att upptäcka risker redan innan något allvarligt händer och för att kunna förbättra och kvalitetssäkra vården. Därför kan det som brukar beskrivas som reflekterande praktik vara viktigt för att vården inte bara ska bli säker utan också av god kvalitet (Gabrielsson \& Ejneborn Looi, 2019a). I kompetensområdet säker vård ingår därför en förståelse för att fel kan inträffa, liksom förmågan att tillsammans i teamet öppet reflektera över såväl begångna fel som identifierade risker utan att enskilda personer ska känna sig anklagade. Detta skapar förutsättningar för ett medvetet patientsäkerhetsarbete när det integreras med kunskaper och färdigheter från övriga kompetensområden.

\section{Att göra bruk av sin kompetens}

Att utöva en profession innebär att vara bärare av ett ansvar, men också att ha en frihet. De krav och förväntningar som finns på professionen är kopplade till professionens grund i såväl vetenskaplig som metodisk kunskap som till en hög etisk standard. Om vi tänker oss handlingsutrymme som ett symboliskt rum, så bidrar krav och förväntningar till väggarna $\mathrm{i}$ det rum inom vilket sjuksköterskor har frihet att handla och använda sin kunskap för patientens bästa. Krav och förväntningar skapar med andra ord såväl förutsättningar och stödjande ramar som begränsningar för 
vad som är önskvärt och möjligt att göra. Ett exempel på det förstnämnda är forskning som visar att sjuksköterskor och annan personal inom hälso- och sjukvården som engagerar sig i mötet med patienter och kan svara upp mot deras behov och förväntningar kan uppleva detta som en källa till energi och tillfredsställelse (Dunn, 2009; Sacco \& Copel, 2018). En möjlig förklaring till detta kan vara att en artikulerad värdegrund ger innehåll och riktning till omvårdnaden (Eriksson, 2018; Martinsen \& Eriksson, 2009), liksom även den kunskap som patienter och närstående bidrar med i bedömning och planering (Karlsson \& Borg, 2017). Detta kan innebära att sjuksköterskor som upplever att de har ledningens förtroende och handlingsutrymme nog för att använda sin professionella kompetens och ge en omvårdnad de kan stå för beskriver sitt arbete som meningsfullt och givande (Bondas, 2009; Chin Chin Lee, Idris \& Delfabbro, 2017; Oljemark, 2014a; Sjølie, Hartviksen \& Bondas, 2020).

Samtidigt lever vi i en tid då organisatoriska system och ekonomiska ramar påverkar sjuksköterskors möjligheter att utforma vården i linje med grundläggande värden och använda sin kompetens i patientens tjänst. Upplevelsen av att handlingsutrymmet och därmed möjligheterna att använda sin kompetens minskar kan skapa stress hos sjuksköterskor, speciellt i situationer där de tycker att de borde kunna göra mer för patienten och/eller upplever den vård som ges som bristfällig (Glasberg, Eriksson \& Norberg, 2007, 2008; Åhlin, 2015).

Detta är en paradoxal situation. $\AA$ ena sidan har sjuksköterskor ett professionsansvar, å andra sidan kan de uppleva sig förhindrade att utöva detta. För att inte öka stressen är det därför viktigt att inte skuldbelägga sjuksköterskor för sådant de inte kan råda över, d.v.s. de begränsningar som finns. Istället behövs stöd för att sjuksköterskor ska kunna använda och utveckla sin kompetens på ett sådant sätt att deras förmåga att göra val som är i linje med den egna professionen stärks. En möjlighet kan vara att vidga perspektivet. Traditionellt - och även i detta kapitel - beskrivs sjuksköterskans kompetens i relation till det patientnära arbetet, eller det man kan tala om som mikronivå. Här skulle ett vidgat perspektiv där sjuksköterskors perspektiv tas tillvara också på meso- och makronivå (Erez \& Gati, 2004; Kapiriri, Norheim, \& Martin, 2007) kunna bidra till att sjuksköterskors kompetens ses som en resurs - såväl av andra som de 
själva - också i teamet och organisationen samt på nationell nivå i högre grad.

Kompetensutveckling bör därför förstås som en kontinuerlig process av reflektion och lärande inte bara för den enskilda sjuksköterskan utan också för organisationens kultur, eftersom dessa står i ett dialektiskt förhållande till varandra (Schein, 2010). Det innebär att det behöver avsättas tid och resurser, inte bara för kunskapsförmedling utan också för reflektion och tillämpning av nya kunskaper och färdigheter. Eftersom handlingsrum inte är fysiska konstruktioner, utan något som skapas när människor interagerar inom ramen för vissa förutsättningar, är emellertid tid och resurser inte nog. Sjuksköterskor behöver ha såväl kunskaper och färdigheter som motivation för att ta den plats som är knuten till professionen och det etiska ansvaret. Detta kan ibland vara en utmaning speciellt i vårdkulturer där sjuksköterskan ses som någon med en assisterande och/eller koordinerande funktion snarare än som en autonom professionsutövare, och där standardiserade metoder uppfattas som oförenliga med de egna idealen och i värsta fall kan innebära att sjuksköterskor överväger att byta arbete (Barker, 2008; Lee, Chiang \& Kuo, 2019; Lindberg-Sand, 1996; Parker, 1990). Att synliggöra de sex kompetensområdena kan vara ett stöd för att synliggöra sjuksköterskors kunnande och bidra till en vård med hög kvalitet (Sherwood \& Barnsteiner, 2012).

\section{Avslutande reflektioner}

Sjuksköterskors professionella kompetens kan beskrivas med utgångspunkt i de sex kompetensområden som Sherwood och Barnsteiner (2012) beskriver som grundläggande för sjuksköterskors arbete. Samtidigt innefattar den professionella kompetensen också något mer än praktiskt och teoretiskt kunnande, nämligen förmågan att hävda detta kunnande. Detta är inte alltid lätt, och förutsätter att sjuksköterskan har ett subjektivt handlingsutrymme och mod och kraft att hävda sin autonomi för att basera sitt handlande på omvårdnadsvetenskaplig kunskap och de etiska värden professionen vilar på (Lindh, da Silva, Berg \& Severinsson, 2010; Price-Dowd, 2017) för att kunna leva upp till de krav och förväntningar som inte bara patienter och närstående utan även samhället har (Helse- og 
omsorgsdepartementet, 2016; Leonardsen, 2019; NOU 2018:16). En autonom sjuksköterska utgår från sin kompetens och agerar på basen av en etisk hållning. Det kan handla om att den autonoma sjuksköterskan kan stå upp för patientens behov gentemot annan personal. Det kan också handla om att ha förmåga att säga nej om en patient ber om något som exempelvis kan innebära en risk - till exempel en suicidal patient som vill bli utsläppt trots att personen kanske blir sur. Autonomi utesluter inte heller samarbete med andra, men samarbetet grundas i att den egna professionens kunskap värderas och bidrar till den gemensamma förståelsen av situationen och vad som bör göras, snarare än att reduceras till en assisterande funktion. Det handlar här om att tillämpa kunskapen på ett vetenskapligt, konstnärligt och etiskt sätt, så att den tillägnas patienten som person (Nåden, 2003). Med andra ord krävs en medvetenhet om vad som utgående från den egna professionens ansvar ska utvecklas, evidensbaseras och bli säkrare, vad informatik ska användas till och vad vi ska samverka om.

Samtidigt är de olika kompetensområdena relevanta också för andra yrkesgrupper. Det är därför inte förvånande att Svensk sjuksköterskeförening och Svenska läkaresällskapet (2017) samt Dietisternas riksförbund (2019) samverkar i kompetensfrågor. Det finns tydliga gemensamma beröringspunkter som är viktiga för god och säker vård, men kompetensen behöver också användas i relation till varje professions - och även de enskilda yrkesutövarnas - specifika ansvar och den vetenskapliga grunden för varje profession. Då kan det unika kunnandet från alla professioner tillvaratas och berika varandra, i stället för att man hamnar i konflikt eller enas om minsta gemensamma nämnare. Med andra ord, sjuksköterskors och andras professioners kompetens ska användas för att värna behoven hos dem som vårdas, och ge bästa tänkbara vård till sårbara människor.

\section{Referenser}

Abuatiq, A. (2015). Concept analysis of technostress in nursing. International Journal of Nursing \& Clinical Practices, 2(110).

Akerjordet, K. (2014). Autentiskt ledarskap i hermeneutiskt ljus. I E. Lassenius \&

E. Severinsson (Red.), Hermeneutik i vårdpraxis. Det nära, det flyktiga, det dolda (s. 163-173). Malmö: Gleerups. 
Alligood, M. R. (Red.) (2018). Nursing theorists and their work (9 ed.). St. Louis, MO: Elsevier.

Alvsvåg, H. (2018). Kari Martinsen: Philosophy of caring. I M. R. Alligood (Red.), Nursing theorists and their work (9 utg., s. 120-139). St. Louis, MO: Elsevier.

Anderson, G. F., Frogner, B. K., Johns, R. A. \& Reinhardt, U. E. (2006). Health care spending and use of information tecnology in OECD countries. Health Affairs, 25(3), 819-831.

Baker, D. P., Day, R. \& Salas, E. (2006). Teamwork as an essential component of high-reliability organizations. Health Research and Educational Trust, 41(4pt2), 1576-1598.

Barker, P. J. (2008). Reclaiming nursing: making it personal. Mental Health Practice, 11(9), 12-16.

Barker, P. J. \& Buchanan-Barker, P. (2004). Beyond empowerment: Revering the story teller. Mental Health Practice, 7(5), 18-20.

Barnett, N. (2018). Person-centred over patient-centred care: Not just semantics. Clinical Pharmacist, 10(4), 98-99.

Birkler, J. \& Dahl, M. R. (2014). Den digitala patienten. Stockholm: Liber.

Bondas, T. (2006). Paths to nursing leadership. Journal of Nursing Management, 14(5), 332-339.

Bondas, T. (2009). Preparing the air for care: A grounded theory study of first line nursing managers. Journal of Research in Nursing, 14(4), 351-362.

Bondas, T. \& Hall, E. O. C. (2007). Challenges in approaching metasynthesis. Qualitative Health Research, 17(1), 113-121.

Bowen, M. \& Mason, T. (2012). Forensic and non-forensic psychiatric nursing skills and competencies for psychopathic and personality disordered patients. Journal of Clinical Nursing, 21(23/24), 3556-3564.

Buchanan-Barker, P. (2004). The Tidal Model: Uncommon sense. Mental Health Nursing, 24(3), 6-10.

Carlström, E., Kvarnström, S. \& Sandberg, H. (2013). Teamarbete i vården. I A.-K. Edberg, A. Ehrenberg, F. Friberg, L. Wallin, H. Wijk \& J. Öhlén (Red.), Omvårdnad på avancerad nivå - kärnkompetenser inom sjuksköterskans specialitsområden (s. 63-101). Lund: Studentlitteratur.

Chin Chin Lee, M., Idris, M. A. \& Delfabbro, P. H. (2017). The linkages between hierarchical culture and empowering leadership and their effects on employees' work engagement: Work meaningfulness as a mediator. International Journal of Stress Management, 24(4), 392-415.

Clarke, J. B. (1999). Evidence-based practice: a retrograde step? The importance of pluralism in evidence generation for the practice of health care. Journal of Clinical Nursing, 6(1), 89-94. 
Colyer, H. \& Kamath, P. (1999). Evidence-based practice. A philosophical and political analysis: some matters for consideration by professional practitioners. Journal of Advanced Nursing, 29(1), 188-193.

Cöster, H. (2003). Att kunna tala allvar med sig själv - utkast till välfärdsskyddets etik och värdegrund (2003:10). Karlstad: Karlstad University Studies.

Dahlberg, K. \& Segesten, K. (2010). Hälsa och vårdande i teori och praxis. Stockholm: Natur \& Kultur.

Dunn, D. J. (2009). The intentionality of compassion energy. Holistic Nursing Practice, 23(4), 222-229.

Edberg, A.-K., Ehrenberg, A., Friberg, F., Wallin, L., Wijk, H. \& Öhlén, J. (2013). Omvårdnad på avancerad nivå - kärnkompetenser inom sjuksköterskans specialistområden. Lund: Studentlitteratur.

Edvardsson, D., Watt, E. \& Pearce, F. (2017). Patient experiences of caring and person-centredness are associated with perceived nursing care quality. Journal of Advanced Nursing, 73(1), 217-227.

Ekman, I., Norberg, A. \& Swedberg, K. (2014). Tillämpning av personcentrering inom hälso- och sjukvård. I I. Ekman (Red.), Personcentrering inom hälso- och sjukvård. Från filosofi till praktik (s. 69-96). Stockholm: Liber.

Ekstrand, P. (2010). Genus och mångfaldsperspektiv i hälso- och sjukvården. I S. Bentling \& B. Jonsson (Red.), Vårdpedagogiska utmaningar (s. 156-185). Stockholm: Liber.

Eldh, A.-C. (2006). Patient participation - what it is and what it is not. (Doktorsavhandling). Örebro: Örebro universitet.

Enarsson, P., Sandman, P.-O. \& Hellzén, O. (2007). The preservation of order: The use of common approach among staff toward clients in long-term psychiatric care. Qualitative Health Research, 17(6), 718-729.

Ennis, G., Happell, B., Broadbent, M. \& Reid-Searl, K. (2013). The importance of communication for clinical leaders in menatl health nursing: The perspective of nurses working in mental health. Issues in Mental Health Nursing, 34(11), 814-819.

Erez, M. \& Gati, E. (2004). A dynamic, multi-level model of culture: From the micro level of the individual to the macro level of a global culture. Applied Psychology, 53(4), 583-598.

Eriksson, K. (2018). Vårdvetenskap. Vetenskapen om vårdandet. Stockholm: Liber.

Eriksson, K., Nordman, T. \& Myllimäki, I. (1999). Den trojanska hästen. Evidensbaserat vårdande och vårdarbete ur ett vårdvetenskapligt perspektiv. (1 utg.). Vasa: Institutionen för vårdvetenskap, Åbo Akademi.

Fawcett, J. (1980). A framework for analysis and evaluation of conceptual models of nursing. Nurse Educator, 5(6), 10-14.

Fawcett, J. (1996). On the requirements for a metaparadigm: An invitation to dialogue. Commentary. Nursing Science Quarterly, 9(3), 94-97. 
Fawcett, J., Watson, J., Neuman, B., Hinton Walker, P. \& Fitzpatrick, J. J. (2001). On nursing theories and evidence. Journal of Nursing Scholarship, 33(2), 115-119.

Finfgeld, D. L. (2003). Metasynthesis: The state of the art - so far. Qualitative Health Research, 13(7), 893-904. https://www.doi.org/10.1177/1049732303253462

Fredriksson, L. (2014). Teoribegreppet inom hermeneutik och vårdande praxis. I E. Lassenius \& E. Severinsson (Red.), Hermeneutik $i$ vårdpraxis. Det nära, det flyktiga, det dolda (s. 43-50). Malmö: Gleerups.

Fredriksson, M., Torjesen, D. O., Tynkkynen, L.-K. \& Vrangbæk, K. (2019). Pasientinvolvering i den nordiske helsetjenesten: Policyutvikling og nåværende praksis. Nordisk Administrativt Tidskrift, 96(3), 9-29.

French, P. (2002). What is the evidence on evidence-based nursing? An epistemological concern. Journal of Advanced Nursing, 37(3), 250-257.

Gabrielsson, S. \& Ejneborn Looi, G.-M. (2019a). Ett personligt ansvar för god och säker vård. I L. Wiklund Gustin (Red.), Vårdande vid psykisk ohälsa - på avancerad nivå (3 ed., s. 569-592). Lund: Studentlitteratur.

Gabrielsson, S. \& Ejneborn Looi, G.-M. (2019b). Reflekterande arbetssätt i psykiatrisk omvårdnad. I I. Skärsäter \& L. Wiklund Gustin (Red.), Omvårdnad vid psykisk ohälsa - på grund nivå (s. 587-601). Lund: Studentlitteratur.

Gabrielsson, S., Sävenstedt, S., \& Olsson, M. (2016). Taking personal responsibility: Nurses' and assistant nurses' experiences of good nursing practice in psychiatric inpatient care. International Journal of Mental Health Nursing, 25(5), 434-443.

Gadamer, H. G. (1989). Truth and method. New York: Continuum.

Gaylord, N. \& Grace, P. (1995). Nursing advocacy: An ethic of practive. Nursing Ethics, 2(1), 11-18.

George, M. (2017). The effect of introducing new public management practices on compassion within the NHS. Nursing Times, 113(7), 30-34.

Gerber, L. (2018). Understanding the nurse's role as a patient advocate. The PeerReviewed Journal of Clinical Excellence, 48(4). Retrieved from https://journals. lww.com/nursing/Fulltext/2018/0400o/Understanding_the_nurse_s_role_as_ a_patient.15.aspx

Glasberg, A.-L., Eriksson, S. \& Norberg, A. (2007). Burnout and 'stress of conscience' among healthcare personnel. Journal of Advanced Nursing, 57(4), 392-403. https://www.doi.org/10.1111/j.1365-2648.2006.04111.X

Glasberg, A.-L., Eriksson, S. \& Norberg, A. (2008). Factors associated with 'stress of conscience' in healthcare. Scandinavian Journal of Caring Science, 22(2), 249-258.

Grimsmo, A., Kirchhoff, R., \& Aarsedt, T. (2015). Samhandlingsreformen i Norge. Organisasjonsstudier, 17(3), 3-12.

Grundy, A. C., Bee, P., Meade, O., Callaghan, P., Beatty, S., Olleveant, N. \& Lovell, K. (2016). Bringing meaning to user involvement in health care planning: A 
qualitative exploration of service user perspectives. Journal of Psychiatric and Mental Health Nursing, 23(1), 12-21.

Hellzén, O., Johansson, A. \& Pejlert, A. (1999). Evidensbaserad omvårdnad vid behandling av personer med schizofreni. Stockholm: SBU/SFF.

Helsedirektoratet. (2018). Retningslinjer for veiledet praksis for psykolog med lisens -presiseringer. Hämtat 20 april 2020, från https://www.helsedirektoratet.no/ tema/autorisasjon-og-spesialistutdanning/autorisasjon-og-lisens/dokumenterautorisasjon/Retningslinjer\%2oveiledet\%2opraksis\%2ofor\%2opsykologer.pdf/_/ attachment/inline/5fbf8821-61cf-4812-9a6e-b148916daoeo:d33d6ee1f8639aed927e2ef cfa581faco12f84dc/Retningslinjer\%2oveiledet\%2opraksis\%2ofor\%2opsykologer.pdf

Helse- og omsorgsdepartementet. (2016). Forskrift om ledelse og kvalitetsforbedring $i$ helse- og omsorgstjenesten. Retrieved from https://lovdata.no/dokument/LTI/ forskrift/2016-10-28-1250

Hoffmann, T., Bennett, S. \& Del Mar, C. B. (2017). Evidence-Based Practice Across the Health Professions (3 ed.). Chatswood, NSW: Elsevier Australia.

Holm, A. L. (2014). Hermeneutiska möjligheter i psykiatrisk vårdpraxis. I E. Lassenius \& E. Severinsson (Red.), Hermeneutik $i$ vårdpraxis. Det nära, det flyktiga, det dolda (s. 135-148). Malmö: Gleerups.

Hommel, A., Idwall, E. \& Andersson, A.-C. (2013). Kvalitetsutveckling. I A.-K. Edberg, A. Ehrenberg, F. Friberg, L. Wallin, H. Wijk \& J. Öhlén (Red.), Omvårdnad på avancerad nivå - kärnkompetenser inom sjuksköterskans specialistområden (s. 148-179). Lund: Studentlitteratur.

Hummelvoll, J. K. (1993). Psykiatrisk sykepleie - en holistisk eksistensiell tilnaerming. I J. K. Hummelvoll \& U. Å. Lindström (Red.), Nordiska perspektiv på psykiatrisk omvårdnad (s. 34-57). Lund: Studentlitteratur.

Håkansson Eklund, J., Holmström, I. K., Kumlin, T., Kaminsky, E., Skoglund, K., Höglander, J., ... Summer Meranius, M. (2019). “Same same or different?” A review of reviews of person-centered and patient-centered care. Patient Education and Counseling, 102(1), 3-11.

ICN. (2012). The ICN code of ethics for nurses. Geneva: International Council of Nurses (http://www.icn.ch/about-icn/code-of-ethics-for-nurses/).

Johansson, E. \& Wallin, L. (2013). Evidensbaserad vård. I A.-K. Edberg, A. Ehrenberg, F. Friberg, L. Wallin, H. Wijk \& J. Öhlén (Red.), Omvårdnad på avancerad nivå - kärnkompetenser inom sjuksköterskans specialitsområden (s. 103-145). Lund: Studentlitteratur.

Kapiriri, L., Norheim, O. F. \& Martin, D. K. (2007). Priority setting at the micro-, meso- and macro-levels in Canada, Norway and Uganda. Health Policy, 82(1), 78-94.

Karlsson, B. E. \& Borg, M. (2017). Recovery: Tradisjoner, fornyelser og praksiser. Oslo: Gyldendal akademisk. 
Kirkevold, M. \& Bonnevie, A. (2010). Sygeplejeteorier: Analys og evaluering (3 ed.). København: Munksgaars.

Koivunen, M., Kontio, R., Pitkänen, A., Katajisto, J. \& Välomäki, M. (2013). Occupational stress and implementation of information technology among nurses working on acute psychiatric wards. Perspectives in Psychiatric Care, 49(1), 41-49. https://doi.org/10.1111/j.1744-6163.2012.00339.x

Kristensson Uggla, B. (2014). Personfilosofi - filosofiska utgångspunkter för personcentrering inom hälso och sjuk vård. I I. Ekman (Red.), Personcentrering $i$ hälso- och sjukvård: Från filosofi till praktik (s. 21-68). Stockholm: Liber.

Kvalitetsregistre.no (2020) Nasjonalt servicemiljø for medisinske kvalitetsregistre, retrieved from https://www.kvalitetsregistre.no/registeroversikt

Lee, H. F., Chiang, H. Y. \& Kuo, H. T. (2019). Relationship between authentic leadership and nurses' intent to leave: The mediating role of work environment and burnout. Journal of Nursing Management, 27(1), 52-65. https://www.doi. org/10.1111/jonm.12648

Leksell, J. \& Lepp, M. (Red.). (2013). Sjuksköterskans kärnkompetenser. Stockholm: Liber.

Leonardsen, L. A.-C. (2019). Kartlegging av kompetanse er nødvendig for å sikre gode helsetjenester Tidsskriftet Sykepleien, 107, e-19137.

Lévinas, E. (1988). Etik och oündlighet. Stockholm: Symposion.

Lindahl, B. \& Sandman, P. O. (1998). The role of advocacy in critical care nursing: A caring response to another. Intensive and Critical Care Nursing, 14, 179-186.

Lindberg-Sand, Å. (1996). Spindeln i klistret: Den kliniska praktikens betydelse för utveckling av yrkeskompetens som sjuksköterska, en etnografisk-fenomenografisk studie. Lund: Lunds universitet, Pedagogiska institutionen.

Lindh, I.-B., da Silva, A. B., Berg, A. \& Severinsson, E. (2010). Courage and nursing practice: A theoretical analysis. Nursing Ethics, 17(5), 551-565.

Martin, L. (2018). Informatik $i$ vården. Hälsoinformatik för sjuksköterskor. Lund: Studentlitteratur.

Martinsen, K. (200o). Öyet og kallet. Bergen: Fagbokforlaget.

Martinsen, K. \& Eriksson, K. (2009). Å se og inse. Om ulike former for evidens. Oslo: Akribe.

Mathieson, A., Grande, G. \& Luker, K. (2019). Strategies, facilitators and barriers to implementation of evidence-based practice in community nursing: A systematic mixed-studies review and qualitative synthesis. Primary Health Care Research e Development, 2o(e6).

McKay, C. \& Vanaskie, K. (2018). Partnering for Success: The role of the nurse leader in health information technology implementation for coordination of care. Nurse Leader, 16(6), 385-388. 
McKeown, M., Ridley, J., Newbigging, K., Machin, K., Poursanidou, K. \& Cruse, K. (2014). Conflict of roles: A conflict of ideas? The unsettled relations between care team staff and independent mental health advocates: Independent mental health advocacy. International Journal of Mental Health Nursing, 23(5), 398-408.

Meleis, A. I. (2018). Theoretical Nursing: Development \& Progress (6 ed.). Philadelphia: Wolters Kluwer.

Montgomery Dossey, B. \& Keegan, L. (Red.). (2013). Holistic nursing. A handbook of practice (6 ed.). Burlington, MA: Jones \& Bartlett Learning.

National League for Nursing, N. (2020). Core values. Retrieved from http://www. nln.org/about/core-values

Nelson, R. \& Staggers, N. (2018). Health Informatics. An interprofessional approach. St Louis, MO: Elsevier.

Neumann, C. B., Olsvold, N. \& Thagaard, T. (2016). Omsorgsarbeidets sosiologi. Bergen: Fagboksforlaget.

Norlyk, A., Haahr, A., Dreyer, P. \& Martinsen, B. (2017). Lost in transformation? Reviving ethics of care in hospital cultures of evidence-based healthcare. Nursing Inquiry, early online.

Norsk sykepleierforbund. (2019). Yrkesetiske retningslinjer for sykepleiere. Retrieved from https://www.nsf.no/vis-artikkel/2193841/17102/Yrkesetiske-retningslinjer

NOU 2018:16. Det viktigste først - prinsipper for prioritering $i$ den kommunale helseog omsorgstjenesten og for offentlig finansierte tannhelsetjenester Oslo: Helse- og omsorgsdepartementet.

Nåden, D. (1998). Når sykepleie er kunstutøvelse [When caring is an exercise of art. An examination of some necessary preconditions for nursing as an art]. Vasa: Åbo Akademi University: Departement of Caring Science (doctoral dissertation).

Nåden, D. (2003). Tillegnelsen av klinisk vårdvitenskap og vårdandets kunst. I K. Eriksson \& U. Å. Lindström (Red.), Gryning II. Klinisk vårdvetenskap (s. 63-73). Vasa: Åbo Akademi, Institutionen för vårdvetenskap.

Nåden, D. \& Eriksson, K. (2004). Understanding the importance of Values and Moral attitudes in nursing care in preserving human dignity. Nursing Science Quarterly, 17(1), 86-91.

Oljemark, K. (2014a). An appreciative inquiry into leadership sense-making and possibilities: A story of values in action (Doktorsavhandling). Luton: University of Bedfordshire.

Oljemark, K. (2014b). An appreciative inquiry into leadership sense-making and possibilities: A story of values in action. (Doktorsavhandling). Luton, UK: University of Bedfordshire. Retrieved from http://uobrep.openrepository.com/ uobrep/bitstream/10547/552500/1/K+Oljemark.pdf

Parker, R. S. (1990). Nurses' stories: the search for a relational ethic of care. Advances in Nursing Science, 13(1), 31-40. Retrieved from http://ep.bib.mdh.se/ 
login?url=http://search.ebscohost.com/login.aspx?direct=true $\& \mathrm{db}=\mathrm{jlh} \& \mathrm{AN}=1075$ 24864\&site $=$ ehost-live\&scope $=$ site

Pasientsikkerhetsprogrammet. (2020). Helsedirektoratet. Retrieved from https:// pasientsikkerhetsprogrammet.no

Polit, D. F. \& Beck, C. T. (2017). Nursing research. Generating and assesing evidence for nursing practice. Alphen aan den Rijn: Wolters Kluwer.

Pollard, C. L. (2015). What is the right thing to do: Use of a relational ethic framework to guide clinical decision-making. International Journal of Caring Sciences, 8(2), 362-358.

Price-Dowd, C. (2017). The three stages of courage in nursing. British Journal of Nursing, 26(17), 989, https://www.doi.org/10.12968/bjon.2017.26.17.989.

QSEN. (2019). QSEN Competencies. Retrieved from qsen.org

Ricoeur, P. (1992). Oneself as Another. Chicago: University of Chicago Press.

Ruggiero, K., Pratt, P. \& Antonelli, R. (2019). Improving outcomes through care coordination: Measuring care coordination of nurse practitioners. Journal of the American Association of Nurse Practitioners, 31(8), 476-481.

Rundqvist, E. (2004). Makt som fullmakt [Power as authority] (soctoral dissertation). Vasa: Åbo Akademi, Institutionen för vårdvetenskap.

Rusner, M. (2019). Vård för ett bärkraftigt vardagsliv vid psykisk ohälsa. I L. Wiklund Gustin (Red.), Vårdande vid psykisk ohälsa - på avancerad nivå (3 utg., s. 433-449). Lund: Studentlitteratur.

Sacco, T. L. \& Copel, L. C. (2018). Compassion satisfaction: A concept analysis in nursing. Nursing Forum, 53(1), 76-83.

Sandberg, H. (2011). Samarbetshälsa. Om effektivt samarbete och välbefinnande. Lund: Studentlitteratur.

Sandelowski, M. (2000). Devices and desires - gender, tecnnology and American nursing. Chapel Hill: The University of North Carolina Press.

Sarvimäki, A. \& Sandelin Benkö, S. (2001). Values and evaluation in health care. Journal of Nursing Management, 9(3), 129-137.

Schein, E. H. (2010). Organizational culture and leadership (4 ed.). San Francisco, CA: Jossey-Bass.

Sheard, D. (2004). Person-centred care: The emperor's new clothes? Journal of Dementia Care, 12(2), 22-25.

Sherwood, G. (1999). Meta-synthesis: Merging qualitative studies to develop nursing knowledge. International Journal for Human Caring, 3(1), 37-42.

Sherwood, G. \& Barnsteiner, J. (Red.). (2012). Quality and safety in nursing: A competency approach to improving outcomes. Chichester, UK: Wiley-Blackwell.

Sjølie, B. M., Hartviksen, T. A. \& Bondas, T. (2020). "Navigation to prioritizing the patient" - first-line nurse managers' experiences of participating in a quality improvement collaborative. BMC Health Services Research, 2o(1), 1-13. 
Skär, L. \& Söderberg, S. (2017). The importance of ethical aspects when implementing eHealth services in healthcare: A discussion paper. Journal of Advanced Nursing, 74(5), 1043-1050.

Socialstyrelsen. (2012). Metoder för brukarinflytande och medverkan inom socialtjänst och psykiatri - en kartläggning av forskning och praktik. Retrieved from Stockholm: http://www.socialstyrelsen.se/Lists/Artikelkatalog/ Attachments/18536/2011-12-20.pdf

SOU. (2018:77). Framtidens specialistsjuksköterska - ny roll, nya möjligheter. Stockholm: Statens offentliga utredningar.

Spinzy, Y., Nitzan, U., Becker, G., Bloch, Y. \& Fennig, S. (2012). Does the internet offer social opportunities for individuals with schizophrenia? a cross-sectional pilot study. European Psychiatry, $27\left(\mathrm{~S}_{1}\right), 1$.

Stadin, M., Nordin, M., Broström, A., Magnussin Hanson, L., Westerlund, H. \& Fransson, E. (2016). Information and communication technology stress ar work and development of suboptimal self-rated health. International Archives of Occupational Environmental Health, 89(7), 1049-1058.

Sundlisæter Skinner, M. (2015). En studie av kommunale ledere og legers erfaringer fra samarbeid med helseforetak om kommunale akutte døgnenheter. Nordisk Tidsskrift for Helseforskning, 2(11), 97-112.

Svensk sjuksköterskeförening. (2010). Svensk sjuksköterskeförenings strategi för utbildningsfrågor. Stockholm: SSF.

Svensk sjuksköterskeförening. (2016a). Sjuksköterskans profession. Stockholm: Svensk sjuksköterskeförening (SSF).

Svensk sjuksköterskeförening. (2016b). Värdegrund för omvårdnad. Stockholm: Stockholm: Svensk sjuksköterskeförening (SSF).

Svensk sjuksköterskeförening \& Svenska läkaresällskapet. (2017). Teamarbete \& Förbättringskunskap, två kärnkompetenser för god och säker vård. Stockholm: Svensk sjuksköterskeförening \& Svenska läkaresällskapet.

Svensk sjuksköterskeförening, Svenska läkaresällskapet \& Dietisternas riksförbund. (2019). Personcentrerad vård - för ökad patientsäkerhet och vårdkvalitet. Stockholm: Svensk sjuksköterskeförening (SSF).

Sävenstedt, S. \& Florin, J. (2013). Informations- och kommunikationsteknik. I A.-K. Edberg, A. Ehrenberg, F. Friberg, L. Wallin, H. Wijk \& J. Öhlén (Red.), Omvårdnad på avancerad nivå - kärnkompetenser inom sjuksköterskans specialistområden (s. 217-258). Lund: Studentlitteratur.

van Wijngaarden, E., van det Meide, H. \& Dahlberg, K. (2017). Researching healthcare as a meaningful practice: Toward a nondualistic view on evidence for qualitative research. Qualitative Health Research, 27(11), 1738-1747.

Wallinvirta, E. (2017). Ansvar och makt. I L. Wiklund Gustin \& I. Bergbom (Red.), Vårdvetenskapliga begrepp i teori och praktik (s. 379-391). Lund: Studentlitteratur. 
WHO. (2017). Facilitating evidence-based practice in nursing and midwifery in the WHO European Region. Copenhagen: World Health Organization Regional Office for Europe.

WHO. (2020). What is quality of care and why is it important? Retrieved from https://www.who.int/maternal_child_adolescent/topics/quality-of-care/ definition/en/

Wiklund Gustin, L. (2019). Att integrera teori och praktik i personcentrerad vård. I L. Wiklund Gustin (Red.), Vårdande vid psykisk ohälsa - på avancerad nivå (s. 546-567). Lund: Studentlitteratur.

Wiklund Gustin, L. \& Lindwall, L. (2012). Omvårdnadsteorier i klinisk praxis. Stockholm: Natur \& Kultur.

Willman, A., Bahtsevani, C., Nilsson, R. \& Sandström, B. (2016). Evidensbaserad omvårdnad: En bro mellan forskning och klinisk praktik. Lund: Studentlitteratur.

Zahourek, R. (2009). Holistic nursing research: Challenges and ppportunities. I B. Montgomery Dossey \& B. Keegan (Red.), Holistic nursing: A handbook for practice (s. 675-694). Sudbury, MA: Jones and Bartlett Publishers.

Åhlin, J. (2015). Stress of conscience and burnout among healthcare personnel working in residential care of older people (Doktorsavhandling).

Umeå: Umeå University. Retrieved from https://pdfs.semanticscholar. org/oo23/66e7534da6eb67cb57157b89135f98e27b5a.pdf

Öhrn, A. (2013). Säker vård. I A.-K. Edberg, A. Ehrenberg, F. Friberg, L. Wallin, H. Wijk \& J. Öhlén (Red.), Omvårdnad på avancerad nivå - kärnkompetenser inom sjuksköterskans specialistområden (s. 182-215). Lund: Studentlitteratur. 



\title{
KAPITTEL 4
}

\section{Kompetansebegrepets uklarhet i møte med barnevernets komplekse handlingsrom}

\author{
Margrethe Amalie Tresselt og Grethe M. Borgerød \\ UiT Norges arktiske universitet
}

\begin{abstract}
:
Background: Governmental documents must provide guidance and knowledge for social workers with a focus on child care. They must describe legislative changes, meet employee expectations and evaluate any reforms. To do so, it is important that the language and use of any concepts are interpreted in the same way. One of the terms used by the government in Norway is the word 'competence', which intends to describe to employees in social care services their tasks. The purpose of this chapter is to highlight challenges related to governmental use of the concept of the word 'competence.' The term is used frequently, in the assumption that there is a common and equal interpretation of the word.
\end{abstract}

Method: This study is a text analysis of relevant governmental documents published from 2014. The purpose of this method is to create structured data out of the documents.

Theory: The study applies the perspectives of hermeneutics and phenomenology, combined with the organizational theories by Skau (2017) and Røvik (2007).

Result: We have three findings concerning the term 'competence. The first is that the term is barely defined. The second is that the term is used without a proper structure. The third is that there are few governmental documents that are aimed specifically at child health care workers.

Conclusion: This study shows that the term 'competence', which is used frequently in various contexts, lacks proper definition. This may lead to confusion and misunderstanding with respect to governmental directions and intents versus professional job execution amongst employees at social care services in Norway.

Keywords: Children Welfare Service, competence, interpretation, job execution

Sitering av denne artikkelen: Tresselt, M. A. \& Borgerød, G. M. (2020). Kompetansebegrepets uklarhet i møte med barnevernets komplekse handlingsrom. I B. L. L. Kassah, H. Nordahl-Pedersen \& W.-A. Tingvoll (Red.), Handlingsrom for profesjonalisert velferd: Kommunale tjenester for helse, omsorg og barnevern (Kap. 4, s. 79-103). Oslo: Cappelen Damm Akademisk. https://doi.org/10.23865/noasp.114.ch4 Lisens: CC-BY 4.o. 


\section{Innledning}

Barneverntjenesten må, som andre etater, forholde seg til offentlige dokumenter i sitt daglige virke. Dokumentenes intensjon er å være styrende og retningsgivende for det samfunnsoppdraget ansatte i barneverntjenesten har overfor våre aller mest sårbare. Det er av betydning at dokumentene er entydige, leservennlige og oversettbare til praktisk arbeid.

I nasjonale og internasjonale rapporter, offentlige dokumenter og medieoppslag har det over flere år fremkommet tilbakemeldinger om kompetansemangler i den norske barneverntjenesten. Dette understrekes i Barne-, ungdoms- og familiedirektoratet sin utredning av kompetansehevingstiltak i barnevernet (2019b). I den nye barnevernsreformen er det også økt oppmerksomhet på kompetanse på kommunalt og fylkeskommunalt nivå.

Vår studie viser at begrepet kompetanse i seg selv ikke er selvforklarende eller entydig. I den begrensede grad offentlige dokumenter søker å definere kompetanse, er definisjonen ikke nødvendigvis åpenbar og klar. For den som skal tolke og forstå offentlige styrende dokumenter, og som skal kunne håndtere svært komplekse og krevende saker, kan uklarhet $\mathrm{i}$ viktige begreper bidra til redusert handlingsrom.

Dette kapitlet tar for seg utfordringer knyttet til manglende innhold og struktur i kompetansebegrepet, og at det offentliges forventninger til barneverntjenestens kompetanse er spredt ut over mange offentlige dokumenter.

På bakgrunn av dette velger vi å stille følgende spørsmål: Kan offentlige dokumenters anvendelse av kompetansebegrepet begrense handlingsrommet for ansatte i barneverntjenesten?

\section{Teori og begrepsavklaring}

I dette hovedavsnittet tar vi for oss begrepsavklaringer og teori som er både bakgrunn for analysearbeidet og grunnlag for å svare på forskningsspørsmålet i diskusjonen. 


\section{Kompetanse}

Det er nødvendig å avklare hva vi forstår med begrepet kompetanse. Kompetansebegrepet er omfattende, og det eksisterer ulike mer eller mindre klare definisjoner (NOU 2018: 2, s. 14). Avhengig av kontekst og hvem som anvender begrepet, for eksempel fagfolk, politikere eller menigmann, operasjonaliseres begrepet ulikt av ulike aktører. I forbindelse med barnevernsreformen har Bufdir (2018a, s. 5) også kartlagt hvilke kompetansebehov som er i den kommunale barneverntjenesten, og man har anvendt Skau sin modell av kompetansebegrepets struktur.

Vi har i dette kapitlet derfor valgt å forholde oss til Skau sin definisjon (2017, s. 57). Denne tar utgangspunkt i at det å være kompetent kan være to ting:

a) At man i kraft av sin stilling har rett, eller myndighet, til å gjøre noe.

b) At man har de nødvendige kvalifikasjoner til å fylle en stilling, ivareta bestemte oppgaver eller uttale seg om et spørsmål.

Skau (2017) viser til tre komponenter for profesjonell kompetanse: teoretisk kunnskap, yrkesspesifikke ferdigheter og personlig kompetanse (figur 1). Hun legger vekt på at disse aspektene kommer til uttrykk samtidig, med ulik tyngde, i alle handlinger og samhandlinger (Skau, 2017, s. 58). Kompetanse innebærer på forhånd definerte krav til formell kunnskap, hva som regnes som relevant ferdighetserfaring, og hvilken personlig egnethet som regnes som relevant og betydningsfull. Begrepet gir bare mening i forhold til noe, enten det er en yrkesrolle, en oppgave eller en funksjon (Skau, 2017, s. 57). Kompetansebegrepet er derfor kontekstuelt og må ha en referanse. Skaus definisjon av kompetansekomponenter er i utgangspunktet fagnøytral. Ut fra hvilke kontekstuelle sammenhenger og fagfelt man opererer innenfor, vil spesifikke og relevante fagkrav måtte defineres innenfor de tre profesjonelle kompetansekomponentene. Essensen i dette er at fagkravene må være spesifisert, målbare og forhåndsdefinert.

For å diskutere kompetansekrav til ansatte i kommunalt barnevern er det naturlig å begynne med hvordan begreper kan påvirker barneverntjenesten i et organisasjonsteoretisk perspektiv. 


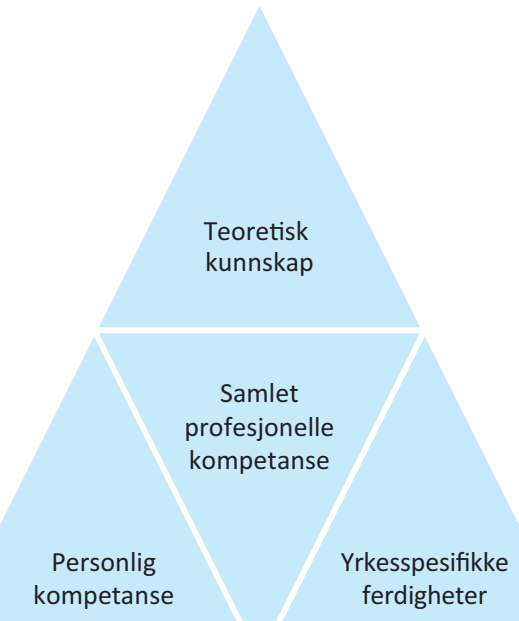

Figur 1 Skaus (2017) kompetansestruktur

\section{Organisasjonen som en kontekst: translasjonsteori og mote}

Organisasjoner og organiseringen av dem, herunder de ansattes handlingsrom, er en del av konteksten i vår sammenheng. Denne konteksten er på ingen måte statisk. Både organisasjoner og organisering av disse påvirkes av politiske og språklige ideer og føringer.

Populære organisasjonsoppskrifter er gjerne godt språkliggjorte ideer, og oppskriftene er ofte det første som blir lagt merke til (Røvik, 1998, s. 148). Over tid overføres de nye begrepene som et virus inn i nye organisasjoner og preger dagligtalen. I organisasjonsforsking kan man benytte ordet mote når man skal forklare hvordan ideer spres mellom organisasjoner (Røvik, 2007, s. 14-15). Det er to sider ved denne tanken. Den ene er det differensierende motivet, som handler om å skille seg ut og være unik. Organisasjoner som er opptatt av dette, ønsker å fremstå som innovative og nyskapende. Den andre er det imiterende motivet, der ønsket er å leve opp til konvensjoner gjennom å etterlikne fordi noe har fått så stor spredning at man er forpliktet til å følge det (Røvik, 2007, s. 14-15). Ifølge Røvik (2007) skjer det noe med innholdet når det overføres ideer til nye institusjoner; innholdet omformes. 
Kompetanse kan kanskje ses på som et tidsriktig moteord. Det knyttes gjerne til bedrifter som har ønske om å uttrykke en profesjonell identitet, gi inntrykk av å være tidsriktige og vise evne til å håndtere forandringer (Røvik, 2007). Begrepet fremstår dermed som positivt ladet. Faren med en slik fortolkning er at den kan innebære en forenkling av fenomener, og anvendelsen kan fremstå som begeistring fremfor som en rasjonell kalkulasjon (Røvik, 2007). Ordet kompetanse blir ofte brukt i offentlige dokumenter, og det er naturlig å knytte det opp mot barneverntjenestens handlingsrom.

\section{Handlingsrom}

Når handlingsrommet til ansatte i kommunalt barnevern skal defineres, vil arbeidsbetingelsene påvirkes av styringen på makronivå (Schönfelder, Andersen \& Kane, 2018, s. 15; Kroken, 2015). Med handlingsrommet til den ansatte i barneverntjenesten forstår vi i denne sammenheng «de muligheter de ansatte har til å ta ansvar for utsatte barn og unge» (Kroken, 2015, s. 17). Slike muligheter er gitt innenfor rammene av jobbeskrivelse, lovgivning, styring og forventning presentert gjennom offentlige dokumenter. Mulighetsrammene er også betinget av den enkelte ansatte sitt eget handlingsrom, med vedkommendes begrensninger og muligheter (Schönfelder et al., 2018, s. 15). Det vil si at handlingsrommet i barnevernet påvirkes av indre og ytre faktorer og av begrensninger og muligheter hos den enkelte profesjonsutøveren (Schönfelder et al., 2018, s. 15).

\section{Språket som redskap og literacy}

I et sosiokulturelt perspektiv skjer påvirkning i en organisasjon gjennom et sosialt og kulturelt fellesskap. Denne forståelsen bygger på en konstruktivistisk tilnærming der det er lagt vekt på at kunnskap blir konstruert gjennom samhandling i en kontekst (Dysthe, 2001). Vygotskij (2001) så for seg at språket var et redskap for egenutvikling og overføring av kultur i et slikt fellesskap. Dette gjelder i hovedsak talespråk, men vi kan tenke oss at det også kan være overførbart til skriftspråk. Vygotskij utdyper at skriftspråket skiller seg fra talespråket, både strukturelt og funksjonelt 
(Vygotskij, 2001, s. 161). Skriftspråket krever høyt abstraksjonsnivå, men mangler talespråkets musikalitet i form av intonasjon og uttrykksfullhet (Vygotskij, 2001). Den skrevne teksten kommer etter den abstrakte tanken. Skriftlige politiske ideer og offentlige dokumenter er i så måte et skriftlig redskap som skal bidra til ny innsikt, gitt at leseren forstår det som står skrevet.

Når en ansatt i barneverntjenesten skal lese og forstå offentlige dokumenter, er det i denne sammenhengen naturlig å trekke inn literacy som et forståelsesbegrep. Literacy omhandler evnen til meningsfortolkning og til å bruke fortolkningen på relevant måte (Hilmarsen \& Arnseth, 2017). Organisasjonen for økonomisk samarbeid og utvikling (OECD) har definert «reading literacy» som evne til «å forstå, bruke og reflektere over og engasjere seg i den skrevne tekst, i den hensikt å oppnå mål, utvikle sin kunnskap og potensial og å delta i samfunnet» (OECD, 2000, s. 5, vår oversettelse). Overført til vår kontekst i dette kapitlet handler det om de ansatte i barneverntjenesten sin literacy, og i denne sammenhengen om at deres forståelse og fortolkning av offentlige tekster har betydning for deres reelle handlingsrom.

\section{Hermeneutikk}

Hermeneutikk er fortolkningslære eller forståelseslære knyttet til tekster (Krogh, 2019, s. 10). Begrepet innbefatter også prosessen mot en forståelse. Ettersom den analysemetodiske tilnærmingen til datamaterialet innebærer blant annet forklaring og tolkning av begreper, er det nødvendig å gi et lite innblikk i hermeneutisk tradisjon. Ikke bare fordi det handler om fortolkning av tekster i seg selv, men også for å redegjøre for forskernes forforståelser.

Ifølge Hans-Georg Gadamer (2012, s. 333) er forforståelsen en viktig forutsetning for å forstå den verdenen man er endel av. Hermeneutikken tar utgangspunkt $i$ at den som ønsker å forstå, har en eller annen form for tilknytning til saken (Gadamer, 2012, s. 333). Forståelse innebærer dermed at ulike selvstendige horisonter (forfatter og leser) smelter sammen (Gadamer, 2012, s. 345). For forskeren, som driver med forskning, er det viktig å synliggjøre egen forforståelse og tilknytning til saken, ettersom 
dette vil påvirke utvelgelse og fortolkning av datamateriale. For praktikeren innen barnevernfeltet handler det om at myndigheters forventninger og ansattes fortolkning av myndighetenes forventninger sammen skal bidra til at hvert enkelt barn får en god oppvekst.

Paul Ricoeur var også opptatt av fortolkning, og han viste til at fortolkningslæren hadde to tradisjoner (referert i Krogh, 2019, s. 89). Den ene er knyttet til religiøs litteratur, i den tro at teksten i seg selv hadde et eget «sannhetsinnhold» som måtte tolkes og lydig respekteres (Krogh, 2019, s. 89). Den andre er en mer kritisk fortolkningstradisjon (mistankens hermeneutikk) som søker å avsløre og gjennomskue teksten i den hensikt å bedre et samfunn (Lægreid, 2006, s. 289). Ricoeur hadde en slik kritisk tilnærming til hermeneutikk. Han viste til at studier av tekster ikke er en dialog mellom tekst og leser (Ricoeur, 1999, s. 139). I motsetning til talen, som er en utveksling av spørsmål og svar, er leseren fraværende fra skrivingen, og forfatteren er fraværende fra lesingen. Teksten er, i motsetning til talen, ikke tilknyttet en kontekst, og den mangler dermed referanser til situasjonen den er skrevet i, og til dens tilhørende virkelighet (Ricoeur, 1999, s. 140). Tekstens verden og leserens verden behøver derfor ikke nødvendigvis å være sammenfallende (Ricoeur, 1999, s. 139).

\section{Metode}

For å finne svar på kapitlets forskningsspørsmål anvender vi kvalitativ tekstanalyse som metode. Kvalitativ tekstanalyse innebærer å ta for seg utvalgte dokumenter og i hovedsak rette søkelyset mot enkelte deler av teksten (Esaiasson, Giljam, Oscarsson, Towns \& Wängnerud, 2012, s. 201) og er fundamentert på den historiske fortolkningstradisjonen, hermeneutikk. Vår kunnskapsinteresse handler om å studere hvordan dokumenter skrevet av Barne- og familiedepartementet og Bufdir benytter kompetansebegrepet som førende for arbeidet i kommunalt barnevern. Vi har tatt utgangspunkt i et utvalg dokumenter utgitt av Barne- og familiedepartementet (tidligere Barne- og likestillingsdepartementet og Barne-, likestillings- og inkluderingsdepartementet) og Bufdir. Dokumentene er fra 2014 og fremover, ettersom 
strukturendringene i barnevernet ble skissert gjennom Sundvoldenerklæringen (Regjeringen, 2013).

\section{Søkeprosess}

Begge forfattere deltok i søkeprosessen, som gikk over tre faser.

I første fase fikk vi oversikt over norskspråklige dokumenter utgitt etter 2014, knyttet til Barne- og familiedepartementet med tilhørende direktorat. Vi endte opp med 417 dokumenter utgitt av Barne- og familiedepartementet, og 133 utgitt av Bufdir.

I andre fase skannet vi de 550 dokumentene i søken etter temaer som er knyttet til barneverntjenestens arbeid - barn, ungdom, familie og barnevern. Dette er mulig å gjøre gjennom søkemotorer i departementet og direktoratet. Vi ble da sittende igjen med 166 dokumenter.

Tredje fase var todelt. For det første reduserte vi den store mengden informasjon gjennom ytterligere inklusjons- og eksklusjonskriterier for å få et håndterbart analysegrunnlag. Innen departementsdokumentene valgte vi ut enkelte typer dokumenter som stortingsmeldinger, NOU-er og proposisjoner. Andre dokumenter, som taler, brev og videoer, ble valgt vekk i denne sammenhengen, ettersom de gjerne er tilknyttet en av utgivelsene til departementet. I direktoratets dokumenter anvendte vi søkemotoren for å skille ut dokumenter som var tilknyttet barneverntjenesten. For det andre valgte vi de dokumentene der kompetansebegrepet kun var knyttet opp mot barneverntjenesten. Selv om kompetansebegrepet ble anvendt flere steder i dokumentene enn det vi viser til, var de gjerne stilet til eksempelvis foreldre eller ungdom. Vi anvendte søkeordet «kompetanse» og krysskoblet det med barneverntjenesten. Dokumenter som ikke uttrykte forventning til kompetansen til ansatte i barneverntjenesten, ble ekskludert.

For å vise hvordan utvelgelsen av dokumenter foregikk, har vi laget et flytdiagram over prosessen (figur 2).

Vi endte opp med 28 dokumenter som ble analysert som fulltekst. Disse dokumentene er listet opp i tabellene på side 88 (tabell 1 og 2). De første dokumentene tilhører departementet, og de siste dokumentene tilhører direktoratet. Disse 28 dokumentene ble tatt med videre til analysearbeid. 


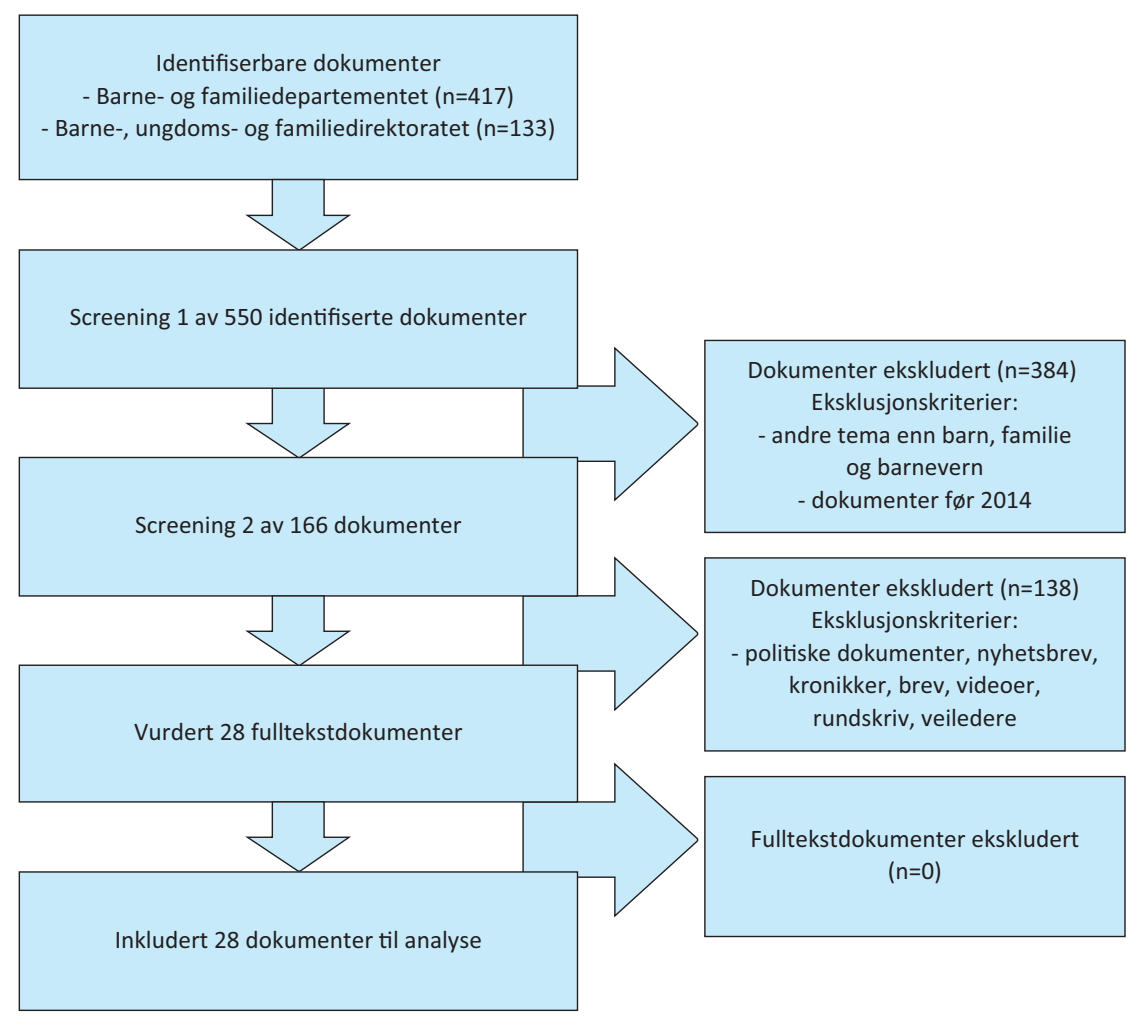

Figur 2 Flytdiagram som viser prosessen for utvelgelse av dokumenter til analyse

\section{Analyse og funn}

For de 28 dokumentene har vi tatt utgangspunkt i Lindseth og Nordberg (2004) sin fenomenologisk-hermeneutiske analysemetodikk. I vår fenomenologiske tilnærming handlet det om en bevissthet som er rettet mot det utforskede fenomenets essens, altså begrepsanvendelse og forståelse av innhold. Fenomenologisk tilnærming var anvendbar ettersom vi brukte empirisk datamateriale fremfor teori (Szklarski, 2012). I den hermeneutiske tilnærmingen var vi inspirert av Ricoeurs (1999) kritiske hermeneutikk, som innebærer å avsløre eller gjennomskue noe for å få bedre innsikt. I våre søk ble vi i tvil om hvorvidt offentlige dokumenter formidler en felles forståelse av kompetanse. Gjennom vår strukturanalyse, der tekstens ulike deler registreres, kommer denne tvilen til uttrykk 
Tabell 1 Utvalg av dokumenter fra departementet til analyse

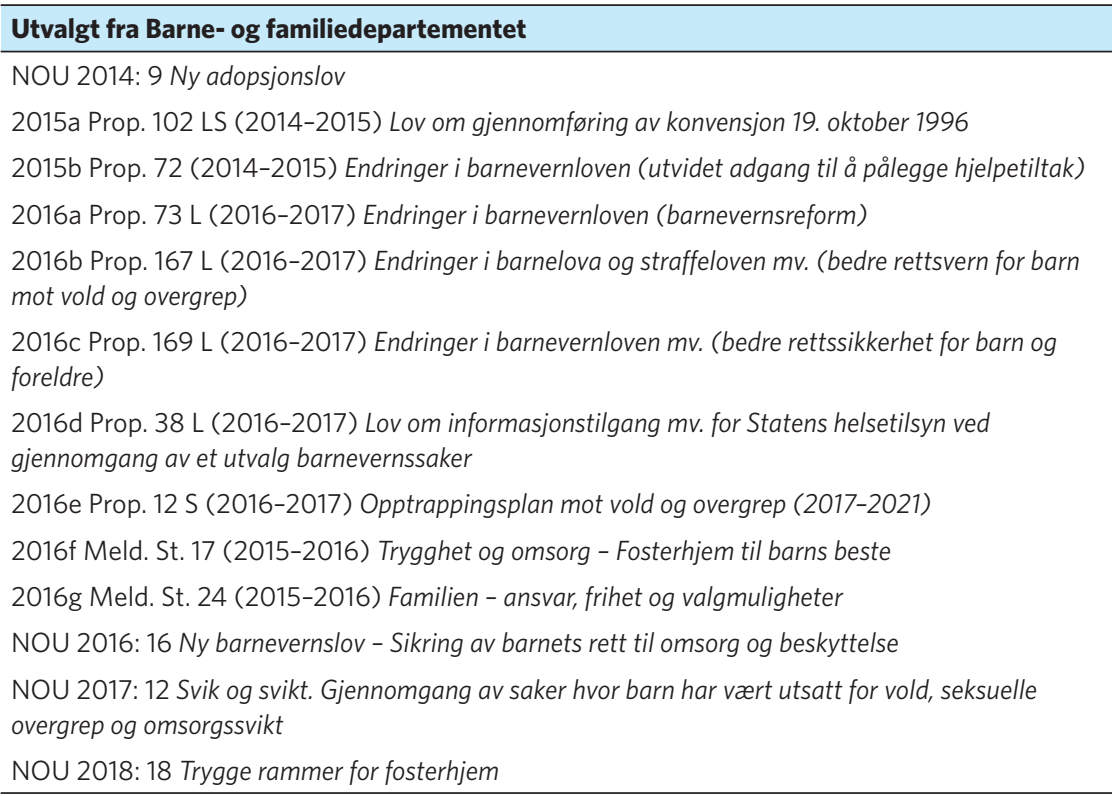

Tabell 2 Utvalg av dokumenter fra direktoratet til analyse

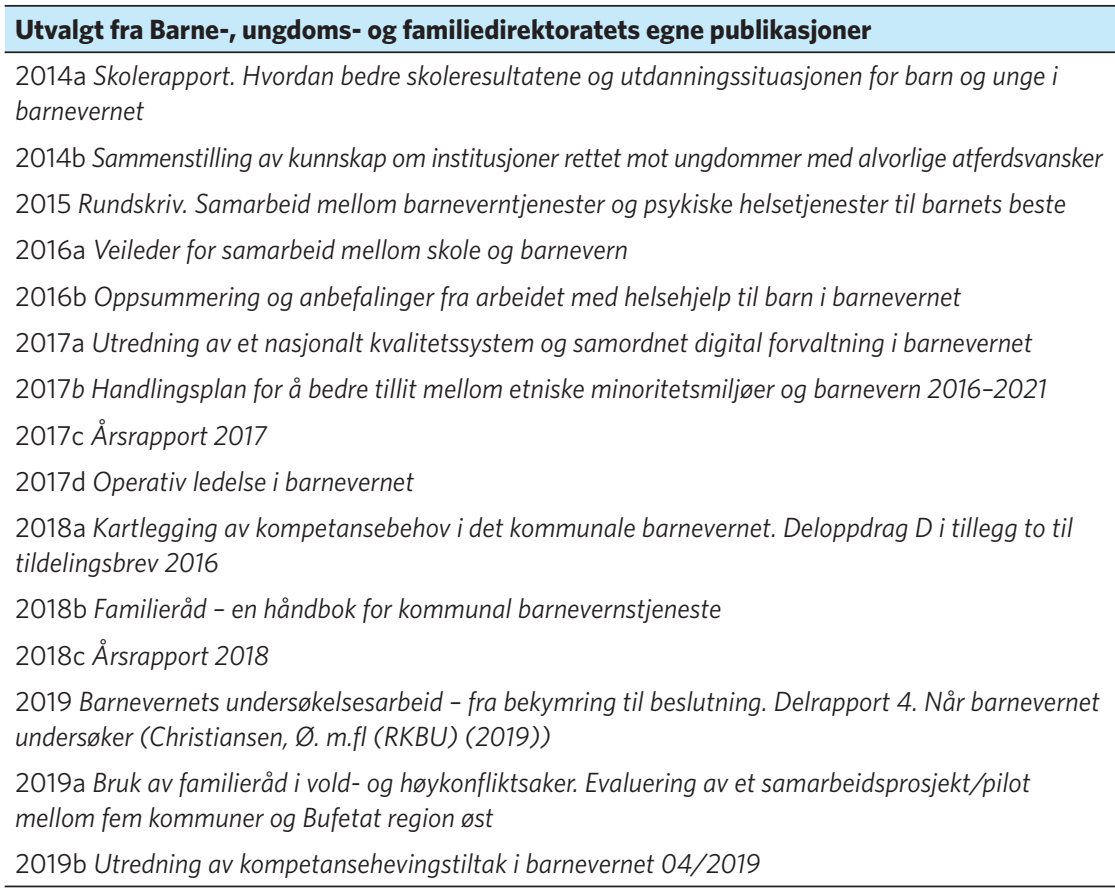


(tabell 3 og 4) for så å tolkes i et større bilde (Westlund, 2009, s. 64). I utgangspunktet ønsket vi å finne ut hva offentlige dokumenter uttrykker som særegen kompetanse for barneverntjenestens ansatte. I denne prosessen fikk vi mistanke om at kompetansebegrepet ble anvendt som et selvforklarende, universelt forstått begrep. Vår interesse dreide seg fra å lete etter arbeidsbeskrivelser for barnevernansatte til å lete etter bruken og forståelsen av kompetansebegrepet i et språklig og fortolkende perspektiv.

Vår analyse, inspirert av Lindseth og Nordberg (2004), innebærer tre steg:

Analyse steg 1: Naiv lesning innebærer å lese materialet med et så åpent sinn som mulig, og å danne seg et inntrykk av helheten kompetansebegrepet ble anvendt i. I gjennomgangen av de 28 utvalgte offentlige dokumentene markerte vi avsnitt som omtalte kompetanse tilknyttet barneverntjenesten. Vi søkte å danne oss et inntrykk av hva barnevernets kompetanse er, og av hvordan kompetanse anvendes som begrep for å gi retning til barneverntjenestens arbeid. Inntrykket vi satt igjen med, var at anvendelsen av kompetansebegrepet ikke var klargjørende og retningsgivende. Dette steget ga retning til neste steg, den strukturelle tematiske analysen.

Analyse steg 2: Strukturell tematisk analyse er en metodisk tolkning av tekstdeler, i dette tilfellet tilknyttet barneverntjenestens kompetanse. Vi søkte å identifisere og formulere temaer ut fra de leste tekstdelene, og vi organiserte disse i tabeller. Vi leste avsnittene uavhengig av dokumentets kontekst for å se om begrepet kompetanse sto som eget innholdsbærende begrep, eller om det var satt sammen med andre ord i et forsøk på å klargjøre innholdet i begrepet (tabell 3 og 4).

Analyse steg 3: Helhetlig fortolkning innebar at vi koblet de identifiserte mønstrene fra analysens steg 2 til kapitlets forskningsspørsmål. De 28 dokumentene ble nå lest gjennom på nytt som en helhet, for å sikre at vi hadde ikke hadde oversett noe. I denne prosessen ble det også naturlig å lete etter litteratur og tidligere forskning som kunne bidra til økt forståelse av våre funn.

Analysen ga tre funn. De to første er knyttet til begrepet kompetanse. Funnene er relatert til hverandre, men kan vurderes separat. Det tredje 
funnet gjelder mangel på dedikerte styrende dokumenter for barneverntjenesten.

Det første funnet gjelder begrepsbruk og innhold. Kompetansebegrepet blir brukt i mange varianter og sammenhenger, uten at det synes å være en enhetlig forståelse av ordets betydning og innhold. Begrepet kompetanse er sjelden definert. I tillegg er begrepet gjerne kombinert med andre ord.

Et utvalg av slike koblinger er vist i tabell 3.

Tabell 3 Begrepet kompetanse i kombinasjon med andre ord

\begin{tabular}{ll}
\hline Dokumenter - eksempler & $\begin{array}{l}\text { Bruk av kompetansebegrepet i kombinasjon } \\
\text { med andre ord }\end{array}$ \\
\hline $\begin{array}{l}\text { Barne- og familiedepartement (2016f). } \\
\text { omsorg - Fosterhjem til barns beste }\end{array}$ & Kompetanseheving \\
& Spesialistkompetanse \\
& Kulturkompetanse \\
& Barnefaglig kompetanse \\
& Samarbeidskompetanse \\
& Kartleggingskompetanse \\
& Utredningskompetanse \\
& Spisskompetanse \\
& Kompetansetiltak \\
& Kompetansekrav \\
Bufdir,(2018c) Årsrapport 2018 & Kompetansemiljø \\
& Kompetanseorgan \\
& Faglig kompetanse \\
\hline
\end{tabular}

Det andre funnet gjelder manglende strukturering av kompetansebegrepets innhold og det er avledet av det første funnet. Vi fant at det ikke bare var nødvendig å klargjøre betydning og innhold i begrepet kompetanse, men at det også var nødvendig å strukturere dette innholdet. I Skaus (2017) modell for den samlede profesjonelle kompetanse tilbys en struktur som beskriver innhold og rammeverk for nødvendig formell kvalifikasjon og forventning. Strukturen danner også grunnlag som referanse for evaluering av innsats i et gitt handlingsrom. Vi begrunner dette i to punkter: 
- Det er et behov for å definere ansattes nødvendige formelle kvalifikasjoner knyttet til en kompleks arbeidshverdag

- Ved evaluering av de ansattes jobbutførelse må denne vurderingen baseres på formaliserte og faglige referanser for jobben.

I flere av de analyserte dokumentene benyttes graderende ord uten referanser, eksempelvis "mye”, "mer”, “svak”, “bred” eller liknende (tabell 4).

Tabell 4 Eksempler på nivellering av kompetansebegrepet

\begin{tabular}{|c|c|}
\hline $\begin{array}{l}\text { Barne- og familiedepartement (2016f). } \\
\text { Meld. St. } 17 \text { (2015-2016) Trygghet og omsorg - Fosterhjem til barns } \\
\text { beste }\end{array}$ & $\begin{array}{l}\text { Svak kompetanse } \\
\text { Bred kompetanse }\end{array}$ \\
\hline Bufdir, (2018c) Årsrapport 2018 & $\begin{array}{l}\text { Spre god praksis og } \\
\text { kompetanse } \\
\text { Høy faglig kompetanse } \\
\text { Riktig kompetanse }\end{array}$ \\
\hline $\begin{array}{l}\text { Barne- og familiedepartement (2016a). } \\
\text { Prop. } 73 \text { L (2016-2017) Endringer i barnevernloven } \\
\text { (barnevernsreform) }\end{array}$ & $\begin{array}{l}\text { Høy kompetanse } \\
\text { Bredde i kompetanse } \\
\text { Mer kompetanse } \\
\text { Bedre kompetanse } \\
\text { Økt kompetanse }\end{array}$ \\
\hline NOU 2018: 18 Trygge rammer for fosterhjem & $\begin{array}{l}\text { Særlig kompetanse } \\
\text { Særskilt kompetanse }\end{array}$ \\
\hline
\end{tabular}

Det tredje funnet er at offentlige dokumenter i liten grad dedikerer sine budskap spesifikt til barneverntjenesten. Dokumentene er temabasert, og avsnittene som handler om barneverntjenesten, er ofte spredt rundt i ulike dokumenter og er fra ulike offentlige instanser.

\section{Forskernes forforståelse}

Som forskere med en hermeneutisk tilnærming er det nødvendig å gjøre rede for egne forforståelser. Med mangeårig erfaring fra barneverntjenesten og utdanningsseksjoner har vi god kjennskap til det å lese offentlige dokumenter - innen våre praksisfelt, men også innen forskning. Erfaringen vi har fra praksisfeltet, vil nødvendigvis også påvirke vår lesing og tolking av offentlige dokumenter. Metodevalg og valg av analysemetode er gjort på bakgrunn av kjennskap til hermeneutisk forskningstilnærming. 


\section{Diskusjon}

Innledningsvis stilte vi oss spørsmålet om offentlige dokumenters anvendelse av kompetansebegrepet kan begrense handlingsrommet for ansatte i barneverntjenesten. Gjennom vår studie noterte vi oss at begrepet kompetanse er innarbeidet som en del av det offentlige skriftspråket. Men det ble samtidig også klart at det måtte stilles spørsmål om hvorvidt begrepet blir entydig brukt og forstått av både dokumentutgiver og dokumentets målgruppe(r).

Vi har delt diskusjonen i fire på bakgrunn av de tre funnene i analysen:

- kompetansebegrepets uklarhet - betydning og innhold

- kompetansebegrepets uklarhet - mangel på referanser

- kompetansebegrepets uklarhet - kjernekompetanse på moten

- kompetansebegrepets uklarhet - mange offentlige aktører

\section{Kompetansebegrepets uklarhet - betydning og innhold}

Begreper innebærer en avgrensning som representerer en allmenngyldig forestilling (Ask \& Eide, 2018, s. 14). Et begrep skal forenkle og tydeliggjøre forhold for leseren, men det er under forutsetning av at begrepet er avgrenset, det vil si definert. Enkelte begreper gir et skinn av å ha et meningsinnhold som alle tilsynelatende aksepterer (Ask \& Eide, 2018, s. 13). Vi forstår kompetansebegrepet som et slikt ord, som gir skinn av å ha et meningsinnhold. Vårt første funn viser at kompetansebegrepets betydning er uklart så lenge det ikke er definert. Det betyr at for det handlingsrommet eller den konteksten begrepet brukes i, blir det i mange tilfeller kun en skinnenighet rundt problemstillinger og faglige referanser. Dette er viktig å forstå, fordi handlingsrom og kontekst er avgjørende for hvilke referanser man skal forholde seg til, i form av spesifikke og relevante fagkrav knyttet til kompetanse. I vårt utvalg av offentlige dokumenter har vi notert oss at det kun er et fåtall av dokumentene (med unntak av eksempelvis dokumentet Kartlegging av kompetansebehov (Bufdir, 2018a) som søker å definere begrepet kompetanse. Vi registrerte også at selv om kompetansebegrepet var definert - eller forklart - var det ikke entydig at definisjonen av kompetanse ble fulgt opp gjennomgående i teksten. Som hovedregel anvendes 
kompetansebegrepet uten å være definert. For eksempel kan man finne kompetansebegrepet anvendt over 200 ganger i årsrapporten for Bufdir $(2017 \mathrm{C})$, uten at det er forklart nærmere hva innholdet i begrepet er. I noen av dokumentene anvendes kunnskap og kompetanse sammen (NOU, 2017: 12, s. 63; NOU 2018: 18, s. 64), noe som antyder at det er forskjell på kunnskap og kompetanse, og at man ikke forholder seg til kompetansebegrepets grunnstruktur. For å få perspektiv på hyppighet registrerte vi at begrepet kompetanse gjentas alt fra to ganger i et dokument til 150 ganger $\mathrm{i}$ andre og opptil rundt 400 ganger i noen. Vi er klar over at dette også har med dokumentets størrelse å gjøre. Vårt poeng - og det vi finner interessant - er at begrepet brukes flittig i offentlige dokumenter, og på en måte som om alle intuitivt forstår hva som menes med kompetanse (se tabell 5).

Tabell 5 Oversikt over dokumenter og antall ganger begrepet kompetanse anvendes

\begin{tabular}{|c|c|}
\hline Dokument & $\begin{array}{l}\text { Antall ganger } \\
\text { «kompetanse» anvendes }\end{array}$ \\
\hline $\begin{array}{l}\text { Barne-, likestillings- og inkluderingsdepartementet. (2015a). } \\
\text { Prop. } 102 \text { LS (2014-2015) Lov om gjennomføring av konvensjon } \\
\text { 19. oktober } 1996\end{array}$ & 56 \\
\hline $\begin{array}{l}\text { Barne-, likestillings- og inkluderingsdepartementet. (2015b). } \\
\text { Prop. } 72 \text { L (2014-2015) Endringer i barnevernloven (utvidet adgang til } \\
\text { å pålegge hjelpetiltak) }\end{array}$ & 150 \\
\hline $\begin{array}{l}\text { Barne- og likestillingsdepartementet. (2016e). } \\
\text { Prop. } 12 \text { S (2016-2017) Opptrappingsplan mot vold og overgrep } \\
\text { (2017-2021) }\end{array}$ & 107 \\
\hline $\begin{array}{l}\text { NOU 2016: } 16 \text { Ny barnevernslov - Sikring av barnets rett til omsorg og } \\
\text { beskyttelse }\end{array}$ & 103 \\
\hline $\begin{array}{l}\text { Barne- og likestillingsdepartementet. (2016a). } \\
\text { Prop. } 73 \text { L (2016-2017) Endringer i barnevernloven (barnevernsreform) }\end{array}$ & 150 \\
\hline $\begin{array}{l}\text { Barne- og likestillingsdepartementet. (2016g). } \\
\text { Meld. St. } 24 \text { (2015-2016) Familien - ansvar, frihet og valgmuligheter }\end{array}$ & 64 \\
\hline $\begin{array}{l}\text { Barne-, likestillings- og inkluderingsdepartementet. (2016f). } \\
\text { Meld. St. } 17 \text { (2015-2016) Trygghet og omsorg - Fosterhjem til barns beste }\end{array}$ & 35 \\
\hline $\begin{array}{l}\text { Barne-, ungdoms- og familiedirektoratet. (2015). } \\
\text { Rundskriv. Samarbeid mellom barneverntjenester og psykiske } \\
\text { helsetjenester til barnets beste }\end{array}$ & 5 \\
\hline $\begin{array}{l}\text { Barne-, ungdoms- og familiedirektoratet. (2017a). } \\
\text { Utredning av et nasjonalt kvalitetssystem og samordnet digital } \\
\text { forvaltning i barnevernet }\end{array}$ & 5 \\
\hline $\begin{array}{l}\text { Barne-, ungdoms- og familiedirektoratet. (2016a). } \\
\text { Veileder for samarbeid mellom skole og barnevern }\end{array}$ & 2 \\
\hline $\begin{array}{l}\text { Barne-, ungdoms- og familiedirektoratet. (2019b) } \\
\text { Utredning av kompetansehevingstiltak i barnevernet 04/2019 }\end{array}$ & 427 \\
\hline
\end{tabular}


Det kan synes som om myndighetene til en viss grad er klar over utfordringene rundt manglende definisjon av kompetanse, og at de søker en begrepsavklaring ved å koble begrepet med et annet, tilsynelatende kvalifiserende tilleggsord. I mange av dokumentene vi gjennomsøkte, fant vi kompetanse knyttet til enten substantiv eller adjektiv. Et utvalg av slike sammensettinger er vist i tabell 3 under avsnittet «Analyse og funn». En fordel med en slik kobling kan være at man i noen tilfeller avgrenser eller spesifiserer konteksten kompetansebegrepet brukes i (eksempelvis kulturkompetanse, samtalekompetanse), men man sitter fortsatt med et udefinert kompetansebegrep. I realiteten er man like langt.

\section{Kompetansebegrepets uklarhet - mangel på referanser}

I funn to etterlyser vi en struktur av kompetansebegrepets innhold, og vi begrunner dette ut fra en definisjon av nødvendig kvalifikasjon for ansatte og referanser knyttet til evaluering av ansattes jobbutførelse. Hvis denne strukturen mangler, er det vanskelig å navigere etter forventninger i offentlige dokumenter. Skau (2017) understreker dette med å vise til at komponentene som utgjør den samlede profesjonelle kompetansen, alltid må ses samlet som profesjonell utøver. Man kan ikke løsrive den ene komponenten fra treenigheten og fremdeles drøfte begrepet kompetanse. Det vil derfor være implisitt i det å inneha en kompetanse tilknyttet barneverntjenesten at man besitter både spesifisert kunnskap, yrkesspesifikke ferdigheter og personlig kompetanse for jobbsituasjonen.

I den virkelige verden er det mye som skal måles. Felles for alle slike situasjoner er at det som måles, måles opp mot en referanse, ellers er målingen meningsløs. Meter måles mot en internasjonalt definert meter, tid måles mot prosesser i cesiumatomet, vindstyrke måles mot en definert skala, og så videre. I vår sammenheng må kompetanse måles mot en tilsvarende relevant referanse. Eksempelvis vises det i NOU 2017: 12 til at det er manglende kompetanse om samtaler med barn hos ansatte i barneverntjenesten. Men hva måles dette mot? Mangler det lest kunnskap om samtaler med barn, mangler det gode samtaleteknikker, eller mangler det 
personlig erfaring og visdom knyttet til det å møte sårbare barn? Behovet for tydeligere grunnlag for referanser og formell struktur er beskrevet av nettopp Skau (2017). Uten en formell referanse kan man ikke måle barnevernets jobbutøvelse, fordi man ikke har noe å måle mot. Eller snudd rundt: Hvordan kan man i offentlige dokumenter peke på mangler i barneverntjenesten når det ikke er referanser å føre manglene opp mot?

Nivellering av kompetansebegrepet er også utbredt i den tilsynelatende hensikten å avklare og spesifisere. Vi har stor kompetanse, lav kompetanse, nok kompetanse, nødvendig kompetanse og mangelfull kompetanse (se tabell 4). Umiddelbart kan dette kanskje se avklarende ut, men begrepet kompetanse er fremdeles like udefinert. Utfordringen er at slike vurderinger må relatere seg til noe, altså ha en referanse: Bedre - i forhold til hva? Nok - i forhold til hva?

Et annet eksempel på hvordan nivelleringen formuleres, er hentet fra Barne-, likestillings- og inkluderingsdepartementet (2016f, s. 68), som skriver at «Barnevernstjenesten må besitte eller ha tilgang til bred kompetanse for å kunne kartlegge barn og familier med forskjellig behov. Mange barnevernstjenester har (vår utheving) god kompetanse på dette feltet». For å få innsikt i hva styrende offentlige dokumenter mener her, må vi få klarhet i om bred kompetanse betyr høyere utdanning eller særskilt relevant erfaring, eller om noen er spesielt egnet for jobben, og om tilstrekkelig kunnskap innebærer en bachelorutdanning. I den grad spesifikasjonen ikke er gitt, har slike vurderinger ikke et substansielt innhold.

\section{Kompetansebegrepets uklarhet - kjernekompetanse på moten}

På godt og vondt vil offentlige dokumenter kunne være «språklige barn av sin tid», påvirket av uttrykk og vendinger som til enhver tid benyttes i det offentlige rom (Røvik, 1998). I en formidlingssammenheng kan dette medføre en utfordring, ettersom formidlingen i seg selv ikke er en dialog mellom tekst og leser (Ricoeur, 1999). I tekstens natur ligger det en avstand i tid og rom, noe som påkaller fortolkning (Lægreid, 2006, s. 297), selv om offentlige tekster er skrevet til lesere som forventes å forstå budskapet. I vår sammenheng kan vi knytte literacy til kunnskapssamfunnets krav 
til profesjonelle barnevernarbeideres evne til å lese, tolke og forstå dokumenter som er knyttet til deres arbeidsoppgaver, og som forutsetningsvis må forstås for å kunne gjøre jobben og delta i arbeidslivet (Skaftun, 2015). Vygotskij viser til skriftspråkets utfordring. Skriftspråket krever et noe høyere abstraksjonsnivå enn talen i møte med andre, og det mangler talespråkets musikalitet i form av intonasjon og uttrykksfullhet (Vygotskij, 2001, s. 161). Nyanser som er selvfølgelige for den som skriver, men som kan misforstås av den som leser. Når språklige uttrykk ikke er tydelig forklart, gir det rom for egentolkning og tilpasset forståelse for leseren. Kjernekompetanse har i noen offentlige dokumenter trådt inn som et tilsynelatende selvforklarende og forståelig begrep. Som et eksempel fremgår det i utredningen av kompetansehevingstiltak i barnevernet (Bufdir, 2019b, s. 41) at man ser det som en utfordring at barnevernet har en uklar kjernekompetanse. Uklar kjernekompetanse forklares med at de ansatte i barnevernet ikke har et felles faglig fundament for å jobbe tverrfaglig, og at det verken er en felles forståelse eller et tydelig skille mellom hva som utgjør henholdsvis kjernekompetanse og supplerende kompetanse (Bufdir, 2019b, s. 41).

I søken etter å forstå hva som måtte ligge i begrepet kjernekompetanse, er det ofte benyttet referanser knyttet til den engelske begrepsforstålsen av «core competence» (Prahalad \& Hamel, 1990). I all hovedsak handler det om bedrifter som viser til særegne, spesifikke produkter med store fordeler eller til spesifikk kunnskap i en profittrelatert markedssammenheng. Lai (2013) skriver at begrepet kjernekompetanse er viktig når strategi skal kobles til (markedsrettet) kompetanse. Kjernekompetanse er den kompetanse som skal sikre langsiktige, konkurransemessige fordeler og overlevelse for organisasjonene. Kjernekompetansen må derfor være mest mulig unik og vanskelig å kopiere av andre, og den må i størst mulig grad bidra til at organisasjonens tjenester og produkter oppfattes som nyttige og verdifulle av brukere (Lai, 2013, s. 34). Et moteord, som vi tolker ordet kjernekompetanse som, er et ord som er hentet fra markedsrettede organisasjoner og bedrifter som har suksess og lykkes (Røvik, 2007). Å imitere kjernekompetanse som begrep fra markedsrettede bedrifter til offentlige etater kan være utfordrende. Det skjer noe med innholdet i ideene når noe flyttes mellom så ulike organisatoriske kontekster (Røvik, 
2007). Eksempelvis benyttes begrepet kjernekompetanse for å indikere at noe er tydelig og særegent for barneverntjenesten (Barne- og likestillingsdepartementet, 2016a, s. 56). Vi er usikre på om kjernekompetanse er et hensiktsmessig begrep i et tverrfaglig og mangefasettert felt som barneverntjenesten. Mye kan tyde på at ansatte i barneverntjenesten også ser det slik. I en rapport utgitt av Vista Analyse på oppdrag av Barne-, likestillings og inkluderingsdepartementet, gir ansatte i barneverntjenesten uttrykk for at det er behov for tydeligere signaler fra myndighetene om hva barnevernet skal være og gjøre (Ekhaugen \& Rasmussen, 2015, s. 90).

\section{Kompetansebegrepets uklarhet - mange offentlige aktører}

I vårt tredje funn fant vi at mange av dokumentene i studien som adresserer barneverntjenesten, også henvender seg til andre etater. I hovedsak har dokumentene et emnefokus. Eksempler på dette finner vi blant annet i Barne-, likestillings- og inkluderingsdepartementet (2016f), som tar for seg trygghet og omsorg for fosterbarn. Dokumentene henvender seg til tverrfaglige omsorgsetater og er ikke spesifikke for barneverntjenesten. Familievernkontor, hjemmetjeneste, barnehage, skole, pedagogiskpsykologisk tjeneste og politi er noen av etatene som nevnes. I enkelte sammenhenger vises det til «tjenesteapparatet» som en samlebetegnelse (NOU 2017: 12, s. 14). Dette dokumentet omhandler et felles tema, men konteksten det er skrevet ut fra, innebærer ikke et direkte budskap til dem som jobber i barneverntjenesten. I Ricoeurs kritiske hermeneutikk fremgår det at hvis «tekstens verden» ikke sammenfaller med «leserens verden», er det rom for misforståelser (Lægreid, 2006). Ifølge Ricoeur (1999, s. 141) er utfordringen at tekstens manglende felles kontekst gjør at de referansene som vises til, blir ubestemmelige og noe som henger i luften. Det skrevne ord blir ord for seg selv, ord som ikke nødvendigvis tolkes slik det var intendert fra myndighetenes side. Man kan tro at man vet hva det å ha tilstrekkelig kunnskap er (Barne-, likestillings- og inkluderingsdepartementet, 2016f, s.), fordi man antar at man har en felles fortolkning av utsagnet. Dette er viktig, fordi konteksten avgjør hvilke referanser man skal forholde seg til, i form av spesifikke og relevante 
fagkrav innen de tre profesjonelle kompetansekomponentene (Skau, 2017). Hvis referansene ikke er tydelige nok, er det vanskelig å reprodusere ideer (Røvik, 2007). Det samme vil være gjeldende for forventninger fra offentlige styringsmyndigheter.

\section{Studiens begrensninger}

Umiddelbart kan 28 dokumenter fremstå som et stort utvalg for en liten undersøkelse, men det er kun en liten prosent av tekstgrunnlaget i hvert enkelt dokument som omhandler barneverntjenestens arbeid. Et stort dokumentvolum var nødvendig for å sikre et godt grunnlag for analysearbeid. I tillegg var det nødvendig å sikre at utvalget var stort nok til muligens å være representativt for utgivelser av departementer og direktorater. Det var et ønske at det belyste temaet skulle tre frem så grundig som mulig. Ved å utelukke andre departementer og direktorater enn Bufdir og Barne- og familiedepartementet er det mulig at vi kan ha oversett dokumenter som kunne ha bidratt ytterligere til å belyse forskningsspørsmålet.

Det å løsrive en setning eller et avsnitt fra en tekst kan, ifølge et hermeneutisk forståelsesperspektiv, føre til at man mister den store sammenhengen. Vi har klippet ut avsnitt og deler fra et helhetlig dokument til analysearbeidet. Det kan være at vi av den grunn har gått glipp av detaljer som kunne ha belyst anvendelsen av kompetansebegrepet videre.

\section{Avslutning}

Innledningsvis spurte vi oss: Kan offentlige dokumenters anvendelse av kompetansebegrepet begrense handlingsrommet for ansatte $i$ barneverntjenesten? Vi har gjennom vår studie av offentlige dokumenter søkt å få en begrunnet avklaring på dette viktige spørsmålet. Vi har vist at kompetansebegrepet er uklart, noe som betyr at det for det handlingsrommet eller den konteksten begrepet brukes i, i mange tilfeller kun blir en skinnenighet rundt problemstillinger og faglige referanser. Vi har vist at bruk av tilleggsord til begrepet kompetanse kan avgrense konteksten, men at det ikke gir noen bedre forståelse av selve kompetansebegrepet. Vi har 
vist at det ikke er nok å gi kompetansebegrepet innhold, men at det også er nødvendig å strukturere dette innholdet i formelle elementer, og vi har vist at styrende, offentlige dokumenter bare i noen grad dedikerer sine budskap spesifikt til barneverntjenesten.

Vi har tatt utgangspunkt $\mathrm{i}$ at handlingsrommet for de barnevernansatte er «de muligheter de ansatte har til å ta ansvar for utsatte barn og unge» (Kroken, 2015, s. 17). Dette handlingsrommet er en sum av ytre faktorer som lovgivning, jobbeskrivelse, tilgjengelige ressurser og styring gjennom offentlige dokumenter, men også av indre faktorer som teoretisk kunnskap, faglige ferdigheter og personlige egenskaper og erfaring. Eventuelle uklarheter eller begrensninger i noen av disse faktorene, ytre så vel som indre, vil nødvendigvis måtte påvirke handlingsrommet for den barnevernansatte.

I denne studien har vi spesielt sett på den ytre faktoren «styring av barneverntjenesten gjennom offentlige dokumenter». Ut fra våre undersøkelser dokumentert i dette kapitlet, ledes vi til den konklusjonen at myndighetenes anvendelse av kompetansebegrepet vil kunne begrense handlingsrommet for de ansatte i barneverntjenesten.

\section{Referanser}

Ask, T. A. \& Eide, S. B. (2018). Innledning. I T. A. Ask \& S. B. Eide (Red.), Barnevernets begreper - $i$ bevegelse (s. 13-21). Oslo: Gyldendal.

Barne-, likestillings- og inkluderingsdepartementet. (2015a). Lov om gjennomføring av konvensjon 19. oktober 1996 om jurisdiksjon, lovvalg, anerkjennelse, fullbyrdelse og samarbeid vedrørende foreldremyndighet og tiltak for beskyttelse av barn, og endringer i enkelte andre lover, og samtykke til ratifikasjon av konvensjonen (Prop. 102 LS (2014-2015)). Hentet fra https://www. regjeringen.no/contentassets/8f9bc655bc5a47798fb93462b9329aaa/no/pdfs/ prp2014201501020oodddpdfs.pdf

Barne-, likestillings- og inkluderingsdepartementet. (2015b). Endringer i barnevernloven (utvidet adgang til å pålegge hjelpetiltak) (Prop. $72 \mathrm{~L}$ (2014-2015)). Hentet fra https://www.regjeringen.no/contentassets/ b727c1523d6a47fbb46ab946f3fe156b/no/pdfs/prp2014201500720oodddpdfs.pdf

Barne- og likestillingsdepartementet. (2016a). Endringer i barnevernloven (barnevernsreform) (Prop. 73 L (2016-2017)). Hentet fra: https://www.regjeringen. no/no/dokumenter/prop.-73-1-20162017/id2546056/ 
Barne- og likestillingsdepartementet. (2016b). Endringer i barnelova og straffeloven $m v$. (bedre rettsvern for barn mot vold og overgrep) (Prop. 167 L (2016-2017)). Hentet fra https://www.regjeringen.no/contentassets/8670626d34bd467fa7oce93730f88382/no/ pdfs/prp2016201701670oodddpdfs.pdf

Barne- og likestillingsdepartementet. (2016c). Endringer i barnevernloven mv. (bedre rettssikkerhet for barn og foreldre) (Prop. $169 \mathrm{~L}$ (2016-2017)). Hentet fra https:// www.regjeringen.no/contentassets/23e2789a4faf47a4b32eao867ad3a111/no/pdfs/ prp2016201701690oodddpdfs.pdf

Barne- og likestillingsdepartementet. (2016d). Lov om informasjonstilgang $m v$. for Statens helsetilsyn ved gjennomgang av et utvalg barnevernssaker (Prop. 38 L (2016-2017)). Hentet fra https://www.regjeringen. no/contentassets/9de966717ce3443794225boe17167539/no/pdfs/ prp2016201700380oodddpdfs.pdf

Barne- og likestillingsdepartementet. (2016e). Opptrappingsplan mot vold og overgrep (2017-2021) (Prop. $12 \mathrm{~S}$ (2016-2017)). Hentet fra https://www. regjeringen.no/contentassets/f53d8d6717d84613b9fofc87deab516f/no/pdfs/ prp2016201700120oodddpdfs.pdf

Barne-, likestillings- og inkluderingsdepartementet. (2016f). Trygghet og omsorg Fosterhjem til barns beste (Meld. St. 17 (2015-2016)). Hentet fra https://www. regjeringen.no/contentassets/aca456569b1d41e9abd37a2a8038637e/no/pdfs/ stm2015201600170oodddpdfs.pdf

Barne- og likestillingsdepartementet. (2016g). Familien - ansvar, frihet og valgmuligheter (Meld. St. 24 (2015-2016)). Hentet fra https://www. regjeringen.no/contentassets/8e378de25cfa49f28851cboef91a7f82/no/pdfs/ stm2015201600240oodddpdfs.pdf

Barne- og likestillingsdepartementet. (2017). Mer kunnskap - bedre barnevern. Kompetansestrategi for det kommunale barnevernet 2018-2024. Hentet fra: https:// www.regjeringen.no/contentassets/6e31905299774f5681d57311e284d519/bedrebarnevern.pdf

Barne-, ungdoms- og familiedirektoratet. (2014a). Skolerapport. Hvordan bedre skoleresultatene og utdanningssituasjonen for barn og unge i barnevernet (Skolerapport 2013). Hentet fra https://bibliotek.bufdir.no/BUF/101/Skolerapport_ barnevern_Bufdir_2014.pdf

Barne-, ungdoms- og familiedirektoratet. (2014b). Sammenstilling av kunnskap om institusjoner rettet mot ungdommer med alvorlige atferdsvansker og/eller vedvarende misbruk av rusmidler (Rapport). Hentet fra https://bibliotek.bufdir. no/BUF/101/Sammenstilling_av_kunnskap_om_institusjoner_for_ungdommer_ med_alvorlige_atferdsvansker_2014.pdf

Barne-, ungdoms- og familiedirektoratet. (2015). Samarbeid mellom barneverntjenester og psykiske helsetjenester til barnets beste (Rundskriv). Hentet fra https://www.helsedirektoratet.no/tema/barnevern 
Barne-, ungdoms- og familiedirektoratet. (2016a). Veileder for samarbeid mellom skole og barnevern. Hentet fra https://bufdir.no/Barnevern/Skoleveileder/

Barne-, ungdoms- og familiedirektoratet. (2016b). Oppsummering og anbefalinger fra arbeidet med helsehjelp til barn i barnevernet (Rapport). Hentet fra https:// bufdir.no/contentassets/98982f50657947d992c24f325cbb52d2/oppsummering-oganbefalinger-fra-arbeidet-med-helsehjelp-til-barn-i-barnevernet.pdf

Barne-, ungdoms- og familiedirektoratet. (2017a). Utredning av et nasjonalt kvalitetssystem og samordnet digital forvaltning i barnevernet (Rapport). Hentet fra https://static1.squarespace.com/static/54ddefa8e4bood9d89b3479e/t/5740do29555 9869e3a17b5da/1463865404134/Utredning+av+et+nasjonalt+kvalitetssystem+ og+samordnet+digital+forvaltning.pdf

Barne-, ungdoms- og familiedirektoratet. (2017b). Handlingsplan for å bedre tillit mellom etniske minoritetsmiljøer og barnevern 2016-2021. Hentet fra https:// bibliotek.bufdir.no/BUF/101/Handlingsplan_for_a_bedre_tillit_mellom_ barnevern_og_etniske_minoritetsmiljoer_2016_2021.pdf

Barne-, ungdoms- og familiedirektoratet. (2017c). Årsrapport. Hentet fra https:// bufdir.no/arsrapport2017/

Barne-, ungdoms- og familiedirektoratet. (2017d). Operativ ledelse i barnevernet. Beskrivelse av krav og forventninger. Hentet fra https://bibliotek.bufdir.no/ BUF/101/Operativ_ledelse_i_barnevernet.pdf

Barne-, ungdoms- og familiedirektoratet. (2018a). Kartlegging av kompetansebehov $i$ det kommunale barnevernet. Deloppdrag D i tillegg til to til tildelingsbrev 2016. (Rapport). Hentet fra https://bufdir.no/Bibliotek/Dokumentside/? docId=BUFoooo 4452

Barne-, ungdoms- og familiedirektoratet. (2018b). Familieråd - en håndbok for kommunal barnevernstjeneste. Hentet fra https://bufdir.no/Barnevern/Familierad/

Barne-, ungdoms- og familiedirektoratet. (2018c). Årsrapport 2018. Hentet fra https:// bufdir.no/globalassets/documents/arsrapport-2018.pdf

Barne-, ungdoms- og familiedirektoratet. (2019a). Bruk av familieråd $i$ voldog høykonfliktsaker. Evaluering av et samarbeidsprosjekt/pilot mellom fem kommuner og Bufetat region øst (Rapport). Hentet fra https://bufdir.no/Bibliotek/ Dokumentside/?docId=BUFoooo 4846

Barne-, ungdoms- og familiedirektoratet. (2019b) Utredning av kompetansehevingstiltak i barnevernet (Rapport). Hentet fra https://bufdir.no/ globalassets/bufdirs-kompetanseutredning-endelig.pdf

Christiansen, Ø., Havnen, K. J. S., Iversen, A. C., Fylkesnes, M. K., Lauritzen, C., Nygård, R. H., Jarlby, F. \& Vis, S. A./RKBU. (2019). Barnevernets undersøkelsesarbeid - fra bekymring til beslutning. Delrapport 4. Når barnevernet undersøker. (RKBU, Rapport 4). Hentet (9.11.20) fra https://bufdir.no/Bibliotek/ Dokumentside/?docId=BUFoooo5048 
Dysthe, O. (Red.). (2001). Dialog, samspel og loering. Oslo: Abstrakt.

Ekhaugen, T. \& Rasmussen, I. (2015). Barnevernet - et utfordrende samliv mellom stat og kommune (Rapportnr. 2015/51). Hentet fra https://www.vista-analyse.no/ site/assets/files/5677/va-rapport_2015-51_barnevernet_et_utfordrende_samliv_ mellom_stat_og_kommune-1.pdf

Esaiasson, P., Giljam, M., Oscarsson, H., Towns, A. \& Wängnerud, L. (2012). Metodpraktikan. Konsten att studera samhälle, individ och marknad. Stockholm: Norstedts Juridik.

Gadamer, H.-G. (2012). Sannhet og metode (L. Holm-Hansen, Overs.). Oslo: Pax forlag.

Hilmarsen, H. V. \& Arnseth, H. C. (2017). Livet på Instagram. Ungdoms digitale forlengelser av sosiale relasjoner og vennskap. Tidsskrift for ungdomsforskning, $17(1), 3-23$.

Krogh, T. (2019). Hermeneutikk. Om å forstå og tolke. (2. utg.). Oslo: Gyldendal.

Kroken, R. (2015). Ansvar i barnevern. Om handlingsrom i den kommunale barnevernstjenesten. Oslo: Gyldendal Akademisk.

Lai, L. (2013). Strategisk kompetanseledelse (3. utg.). Oslo: Fagbokforlaget.

Lindseth, A. \& Nordberg, A. (2004). A phenomenological hermeneutical method for researching lived experiences. Scandinavian Journal of Caring Sciences, 18(2), 145-153.

Barnevernloven. (1992). Lov om barneverntjenester (LOV-1992-07-17-100). Hentet fra https://lovdata.no/dokument/NL/lov/1992-07-17-10o?q=lov\%20om\%20 barneverntjenester

Lægreid, S. (2006). Paul Ricoeur - formidlingens tenker, hermeneutikkens brobygger. I S. Lægreid \& T. Skorgen (Red.), Hermeneutikk - en innføring (s. 287-303). Oslo: Spartacus.

NOU 2014: 9. (2014). Ny adopsjonslov. Hentet fra https://www.regjeringen. no/contentassets/bc5egfbf3dda4300849oboaa32846fac/no/pdfs/ nou20142014000900odddpdfs.pdf

NOU 2016: 16. (2016). Ny barnevernslov - Sikring av barnets rett til omsorg og beskyttelse. Hentet fra https://www.regjeringen.no/no/dokumenter/nou-2016-16/ id2512881/

NOU 2017: 12. (2017). Svik og svikt. Gjennomgang av saker hvor barn har voert utsatt for vold, seksuelle overgrep og omsorgssvikt. Hentet fra https://www. regjeringen.no/contentassets/a44ef6e251cd443396588483e97402ab/no/pdfs/ nou2017201700120oodddpdfs.pdf

NOU 2018: 18. (2018). Trygge rammer for fosterhjem. Hentet fra https://www. regjeringen.no/no/dokumenter/nou-2018-18/id2622734/ 
NOU 2018: 2. (2018). Fremtidige kompetansebehov 1 - Kunnskapsgrunnlaget. Hentet fra https://www.regjeringen.no/contentassets/e6acac1df4964805a34c767fa9309acd/no/ pdfs/nou2018201800020oodddpdfs.pdf

Organisasjonen for økonomisk samarbeid og utvikling (OECD). (2000). Literacy in the Information Age. Final report of the International Adult Literacy Survey (Rapport). Hentet fra https://www.oecd.org/education/skills-beyondschool/41529765.pdf

Prahalad, C. K. \& Hamel, G. (1990). The core competence of the corporation. Harvard Business Review, 67(3).

Regjeringen. (2013). Politisk plattform for en regjering utgått av Høyre og Fremskrittspartiet (Sundvolden-plattformen). Hentet fra https://www.regjeringen. no/contentassets/a93bo67d9b604c5a82bd3b5590096f74/plattform.pdf

Ricoeur, P. (1999). Eksistens og hermeneutikk (H. H. Ystad, Overs.). Oslo: Aschehoug.

Røvik, K. A. (1998). Moderne organisasjoner. Trender i organisasjonstenkningen ved tusenårskiftet. Bergen: Fagbokforlaget.

Røvik, K. A. (2007). Trender og translasjoner. Ideer som former det 21. århundrets organisasjon. Oslo: Universitetsforlaget.

Schönfelder, W., Andersen, S. T. \& Kane, A. A. (2018). Handlingsrom i barnevernet. Muligheter og begrensninger for profesjonsutøveren. Bergen: Fagbokforlaget

Skaftun, A. (2015) Leseopplæring og fagenes literacy. Nordic Journal of Literacy Research, 1, 1-15. http://dx.doi.org/10.17585/njlr.v1.170

Skau, G. M. (2011). Gode fagfolk vokser. Personlig kompetanse i arbeid med mennesker (4. utg.) Oslo: Cappelen Damm Akademisk.

Skau, G. M. (2017). Gode fagfolk vokser. Personlig kompetanse i arbeid med mennesker (5. utg.) Oslo: Cappelen Damm Akademisk.

Szklarski, A. (2009). Fenomenologi som teori, metodologi och forskningsmetod. I A. Fejes \& R. Thornberg (Red.), Handbok i kvalitativ analys (s. 106-121). Stockholm: Liber.

Vygotskij, L. S. (2001). Tenking og tale. (T. Jarl-Bielenberg, Overs.). Oslo: Gyldendal Akademisk.

Westlund, I. (2009). Hermeneutik. I A. Fejes \& R. Thornberg (Red.), Handbok i kvalitativ analys (s. 71-88). Stockholm: Liber. 



\title{
Ledelse av profesjonalisert velferd $i$ et paradoksteoretisk perspektiv
}

\author{
Bodil S. Olsvik \\ UiT Norges arktiske universitet
}

\begin{abstract}
Despite an increased focus on the professionalisation of welfare leadership, leadership challenges in the healthcare sector and child welfare services are an unexplored area. This chapter deals with welfare leadership, and attention is directed at the nature of these challenges and how paradox theory can be used to describe and explain them. This chapter shows that the framework and conditions of welfare leadership are often contradictory and that demands and expectations are often characterised by paradoxes. Major reforms have been implemented in Norway in recent years, and increased quality, expanded expertise and stronger leadership have been among the focus areas. Many leaders in the healthcare sector and child welfare services increasingly experience conflicting and intersecting governance requirements, and everyday leadership is characterised by complexity, uncertainty and stress. Leaders in complex, contradictory and quotidian conditions experience challenges in the areas of managerial discretion and broader leadership competence. Finally, the author discusses the need for leaders to develop competence in handling dilemmas by acquiring training in paradoxical thinking and handling complexity.
\end{abstract}

Keywords: dilemma competence, welfare leadership, leadership, managerial discretion, paradox theory

\section{Introduksjon}

Kapitlet omhandler ledelse av profesjonalisert velferd med utgangspunkt i et paradoksteoretisk perspektiv (Schad, Lewis, Raisch \& Smith, 2016; Smith \& Lewis, 2011). Problemstillingen for kapitlet er todelt: Hva utgjør ledelsesutfordringene innen profesjonalisert velferd, og hvordan

Sitering av denne artikkelen: Olsvik, B. S. (2020). Ledelse av profesjonalisert velferd i et paradoksteoretisk perspektiv. I B. L. L. Kassah, H. Nordahl-Pedersen \& W.-A. Tingvoll (Red.), Handlingsrom for profesjonalisert velferd: Kommunale tjenester for helse, omsorg og barnevern (Kap. 5, s. 105-129). Oslo: Cappelen Damm Akademisk. https://doi.org/10.23865/noasp.114.ch5

Lisens: CC-BY 4.0. 
kan disse utfordringene beskrives og forklares ved hjelp av paradoksteori? Videre drøftes hva disse lederutfordringene betyr for ledernes kompetanse.

Konteksten for dette kapitlet er ledelse av kommunal helse- og omsorgstjeneste og barneverntjeneste. Ledelse av disse tjenestene har mange fellestrekk og omtales her samlet som ledelse av profesjonalisert velferd. Formålet med kapitlet er å bidra til økt forståelse av lederskap i praksis og vilkår for ledelse i denne spesifikke konteksten. Rammer og betingelser for ledelse i denne konteksten er ofte motsetningsfylte, noe som påvirker ledernes handlingsrom. Økt forskningsbasert kunnskap om ledelse innen disse kommunale områdene vil kunne gi oss økt kunnskap om hvilket handlingsrom som finnes for ledelse innen profesjonalisert velferd, samt bidra til å gi lederne større innsikt i egen situasjon. Det kan igjen bedre grunnlaget for å si noe om hvordan og på hvilke områder man bør styrke lederkompetansen.

Ulike støtteteorier kan bidra til forståelsen av lederskap. I dette kapitlet anvendes paradoksteori for å kaste lys over lederskap og dets sentrale aspekter. Ved hjelp av paradoksteorien kan vi forstå lederskap som en funksjon som må takle motstridende krav i organisasjonen. Paradoksteorien retter søkelyset mot samspillet av motsetningsfylte krefter, og den har som utgangspunkt at ulike motsetninger er til stede samtidig og vedvarer over tid (Kirkhaug, 2015; Smith \& Lewis, 2011). Lederskap i en motsetningsfylt hverdag krever lederskap med både dybde og bredde. Det innebærer at man som leder må kunne utvise både råskap og omsorg, kunne gi frihet og ta full kontroll samt opptre både demokratisk og autoritært. Lederskap må variere ut fra situasjon, noe som utfordrer lederne når det gjelder både kompetanse og handlingsrom (Kirkhaug, 2015).

Kapitlet baserer seg på to litteraturgjennomganger om paradoksteori og paradoksledelse gjennomført av Schad et al. (2016) og Johansen (2018). I tillegg er det utført usystematiske litteratursøk i nasjonale og internasjonale databaser etterfulgt av gjennomgang av referanselistene i sentrale publikasjoner fra disse usystematiske søkene (Thagaard, 2016). Det ble gjort usystematiske søk etter vitenskapelige artikler og antologier i Google, Google Scholar og Oria. Følgende søkeord ble benyttet: paradoksteori, paradokser, motsetningsfylt, motsetninger, ledelse og lederskap. 
Søkeordene ble benyttet i kombinasjon med ordene kommune, helse- og omsorgstjenester, helse- og omsorgssektor, barnevern, barneverntjeneste, omsorgstjenester og helsetjenester.

Mot slutten av 1990-årene ble reformideer med rot i New Public Management (NPM) gjennomført i offentlig virksomhet i Norge (Christensen, 2012; Vabø, 2007). Med NPM kom oppmerksomhet på økt effektivitet, horisontal spesialisering og lederprinsipper fra privat sektor, samt at begreper som kostnadseffektivitet, resultatoppnåelse, kvalitetsmåling og brukertilfredshet ble en del av hverdagen til ledere og ansatte i offentlig sektor (Christensen, 2012; Ponnert \& Svensson, 2016). Spesialisering har ført til en økende fragmentering av tjenestene, og behovet for bedre samhandling både internt og mellom de ulike velferdssektorene har vokst fram. Nye reformer har kommet til for å bøte på dette, som blant annet samhandlingsreformen og barnevernsreformen (Fossum, Lauritzen, Vis, Ottosen \& Rustad, 2015; Vik, 2018). I disse reformene utgjør økt kvalitet, kompetanse og sterkere ledelse noen av fokusområdene (Barne- og likestillingsdepartementet, 2017a; Helse- og omsorgsdepartementet, 2009). Med horisontal spesialisering, nye styringsidealer samt reformer har vilkårene for lederskap endret seg. Mellomledere har i større grad fått et mer selvstendig ansvar for budsjett, fag og personal (Shanks, Lundström \& Wiklund, 2015; Aaltvedt, Juvland \& Öresland, 2017). Samtidig utfordres lederskapet gjennom de motsetningene som preger mange organisasjoner, for eksempel samtidige krav om delegering og sentralisering, frihet og kontroll, utnytting og ivaretagelse, samarbeid og individualitet, kvalitet og effektivitet (Kirkhaug, 2019; Kvello \& Moe, 2014; Lewis \& Smith, 2014; Smith \& Lewis, 2011). Ledelse av profesjonalisert velferd handler dels om å forstå enkeltindividers behov for hjelp og støtte, og dels om å rasjonere knappe ressurser og sørge for at mennesker behandles formelt riktig og rettferdig. Både helse- og omsorgslederen og barnevernlederen skal ivareta et vidt spenn av hensyn og krav. Mange barnevernledere opplever at de i økende grad er utsatt for motstridende krav og forventninger (Olsvik \& Saus, 2020), noe som kan føre til paradoksale spenninger i lederhverdagen (Knight \& Paroutis, 2017).

I det følgende presenteres først nyere definisjoner på lederskap, deretter introduseres det teoretiske rammeverket. Det paradoksteoretiske 
grunnlaget blir presentert, samtidig som det også vil være nødvendig å berøre kompleksitetsteorien, siden denne er regnet som grunnlaget for paradoksteorien. Videre presenteres lederskap innen profesjonalisert velferd, hvor både betingelser for ledelse av profesjonalisert velferd og ledelsesutfordringer løftes fram. Det diskuteres hvilke implikasjoner betingelser og utfordringer har for ledernes kompetanse og handlingsrom, før det gjøres en kort oppsummering av kapitlet til slutt.

\section{Ulike definisjoner på lederskap}

Tradisjonelt har man innen ledelseslitteraturen vært opptatt av å skille mellom administrasjon og ledelse. Administrasjon handler om hvordan man som leder tilrettelegger ved å fastsette mål, verdier og rammer, samt at man også skal ivareta en kontrollfunksjon. Ledelse har derimot vært konsentrert om det relasjonelle (Kirkhaug, 2015). Nyere ledelseslitteratur har i stor grad gått bort fra dette skillet og bruker i stedet begrepet lederskap, som inkluderer både administrasjon og relasjonelle funksjoner (Crosby \& Bryson, 2018, s. 1268). Lederskap omfatter utvikling og ivaretagelse av medarbeidere, det kollegiale settes foran det individuelle, og man tar hensyn til alle interessenter (Crosby \& Bryson, 2018; Kirkhaug, 2015).

Gjennom årenes løp har lederskapsstudier hatt ulike teoretiske tilnærminger. Fram til 1950-årene var studiene orientert mot ledernes personlige egenskaper, som intelligens, selvtillit, fleksibilitet og følelsesmessig modenhet. Det førte videre til studier hvor man fokuserte på ledernes adferd, og lederskapsdefinisjoner med utgangspunkt i ledernes adferd har vært dominerende siden 1950-årene. Sentralt i tradisjonelle definisjoner av lederadferd finner vi begreper som mål, kommunikasjon, påvirkning, motivasjon, beslutning og kontroll (Kirkhaug, 2015). Videre rettet ledelsesforskningen søkelys mot hvordan ulike lederstiler er nødvendig for ulike kontekster, som i betingelsesteori (Fiedler, 1967; Hersey \& Blanchard, 1988). I løpet av 1970-årene oppsto mange nye tilnærminger til lederskap, som lederskap som tjenerfunksjon og lederskap som delt lederskap (Orazi, Turrini \& Valotti, 2013). Lederskap som tjenerfunksjon blir på engelsk kalt «servant leadership», som 
handler om at lederen tar vare på, veileder og utvikler medarbeiderne, og lederskapet formes på medarbeidernes premisser. Ved delt lederskap forstås lederskapet som en delt funksjon ved at det ivaretas av flere. Man snakker gjerne om distribuert eller delt lederskap, hvor også teamledelse innbefattes av denne definisjonen (Kirkhaug, 2019). Mot slutten av 1970-årene kom teorier om transaksjonsledelse og transformasjonsledelse inn i litteraturen (Orazi et al., 2013, s. 488). Transaksjonsledelse er brukt for å beskrive ledere som er opptatt av kortsiktig tenkning og av å forvalte det bestående. Transformasjonsledelse er relasjonsorientert og vektlegger utvikling og endring (Kirkhaug, 2015). De senere årene har vi sett en utvikling mot å se på lederskap som en helhetlig funksjon, hvor helhet, likevekt, visjoner, filosofi og vitenskap har en sentral plass. Lederne skal håndtere alle utfordringene som oppstår, samtidig som det skal tas hensyn til alle de involverte primærinteressentene (mottakere av tjenestene, medarbeidere og eiere), noe som anses som viktig for å ivareta legitimitet, balanse og stabilitet (Crosby \& Bryson, 2018; Kirkhaug, 2015; Orazi et al., 2013).

Forskning på lederskap i offentlig sektor har beveget seg fra ledersentrerte til systemsentrerte tilnærminger (Ospina, 2017). Det ser vi ved at oppmerksomheten har blitt flyttet fra transformasjonsledelse, som er den mest ledersentrerte tilnærmingen, til delt ledelse og kollektiv ledelse, som er den mest systemsentrerte (Ospina, 2017). Denne utviklingen mot en mer system- og relasjonsorientert oppmerksomhet på lederskap ser ikke bort fra verdien av ledersentrerte teorier, men tilbyr nye verktøy for å forstå lederskap i dagens situasjon med motstridende krav og forventninger (Ospina, 2017, s. 278). De nye teoriene har ulike merkelapper: nettverksledelse, kompleksitetsledelse og diskursiv ledelse (Crosby \& Bryson, 2018).

Oppsummert ser vi at nyere lederskapstilnærminger ser på lederskap som en kompleks, paradoksal og situasjonsbetinget funksjon. I dagens lederskap framheves utvikling av medarbeidere og deres behov, det kollegiale fremheves framfor det individuelle, og hensynet til alle interessenter er viktig. Lederskapet inneholder dermed både en bredde og en dybde gjennom at det anses både som et tjenerskap og som delt og helhetlig (Kirkhaug, 2015). 


\section{Ledelse av profesjonalisert velferd i et paradoksteoretisk perspektiv}

Lederskap er en kompleks, paradoksal og situasjonsbetinget funksjon. I dette kapitlet belyses lederskap innen profesjonalisert velferd ut fra et paradoksteoretisk perspektiv. Paradoksteorien kan hjelpe oss å forstå og forklare spenninger som oppstår som et resultat av motsetningsfylte krav, og den kan supplere eksisterende teori om lederskap (Schad et al., 2016). Paradoksteorien er basert på kompleksitetsteorien, derfor presenteres først kompleksitetsteorien og deretter paradoksteorien.

\section{Kompleksitetsteori og paradoksteori Kompleksitetsteori}

Opplevelsen av en kompleks og skiftende omverden har medført at vi har fătt en rekke organisasjons- og ledelsesteorier om kompleksitet. Kompleksitetsteori er et samlebegrep for teorier som beskriver komplekse systemer. Kompleksitetsteorien forsøker å forklare og forstå hvordan menneskelige organisasjoner fungerer (Johansen, 2018). En organisasjon ses på som en helhet, og man er mer opptatt av egenskaper ved samspillet og interaksjonene i organisasjonen enn av enkeltdelene. Innen organisasjons- og ledelsesteori gir kompleksitetsteorien et bidrag til nye former for organisasjonsbasert tenkning og forståelse. Kompleksitetsteorien utfordrer tradisjonell organisasjons- og ledelsesteori, som beskriver at organisasjoner organiserer seg ut fra et slags likevektprinsipp, det vil si at de organiseres gjennom like, fastlagte og enkle regler og systemer som alle involverte følger, og slik skapes forutsigbarhet (Johansen, 2018). Kompleksitetsteorien argumenterer for at organisasjoner ikke er forutsigbare, og at det dermed er vanskelig å sette i verk ulike tiltak for å skape et $ø n s k e t$ resultat. Det er samspillet mellom menneskene i organisasjonen som er avgjørende, og som det blir lederskapets oppgave å få til å fungere. Alle handlinger og beslutninger som de ansatte gjør, er influert av deres erfaringer og av relasjonene de har til andre mennesker innenfor og utenfor organisasjonen. Ifølge Stacey og Griffin (2006, s. 6) består organisasjoner først og fremst av mennesker, hvor hver og en har sin agenda 
og sine intensjoner. Menneskene konstruerer virkeligheten i innbyrdes relasjoner som styres av kommunikasjon og mangfold. Dette skaper en uforutsigbar kompleksitet som samtidig driver organisasjonen framover. Forandringene i organisasjonen skjer ved endring i kommunikasjon og relasjoner, og det er umulig å forutse organisatoriske endringer med sikkerhet. For å kunne skape endringer i organisasjonen må ledelsen derfor forholde seg til de interne relasjonene mellom medarbeiderne. Stacey og Griffin (2006) kritiserer på denne måten NPM, som har dominert styrings- og ledelsestenkningen i den offentlige sektoren med sin styrende og lineære forståelse av offentlig ledelse.

Ifølge kompleksitetsteorien består altså organisasjoner av mange faktorer som virker sammen. Faktorene kan være av teknologisk, strukturell, kulturell, sosial og operasjonell karakter (Kirkhaug, 2015). Lederskap er en av faktorene, og de ulike faktorene virker sammen med ulik grad av forutsigbarhet. Kompleksitetsteorier om ledelse tar utgangspunkt i at styring i tradisjonell forstand ikke er mulig, fordi organisasjonens egenskaper oppstår i kompliserte, uforutsigbare samspill mellom enkeltdelene (Johansen, 2018, s. 67). Lederskap kan altså i et kompleksitetsperspektiv forstås som en faktor som både påvirker og blir påvirket av sine skiftende omgivelser, og lederskap vil dermed være i konstant endring (Uhl-Bien \& Arena, 2018).

\section{Paradoksteori}

Paradoksteori vektlegger at det er noen antatte motsetninger som er til stede samtidig, og som vedvarer over tid, mens kompleksitetsteorien retter søkelyset mot uforutsigbare og komplekse samspill mellom ulike faktorer i organisasjoner (Smith \& Lewis, 2011, s. 382). Paradoksforskerne utforsker samspillet av motsetningsfylte krefter på tvers av nivå, tid og fenomener (Lewis \& Smith, 2014). Paradoksteori oppsto mot slutten av 1970-årene som en kritikk og videreutvikling av datidens organisasjonsteori (Johansen, 2018). Bruk av paradoksteori for å forstå lederskap har økt i omfang, fordi andre perspektiver ikke i stor nok grad rommer den økende kompleksiteten vi ser innen organisasjon og ledelse (Johansen, 2018; Lewis \& Smith, 2014; Schad et al., 2016; Schad, Lewis \& Smith, 2019; Smith \& Lewis, 2011).

Paradoksteori anvendes på både makro- og mikronivå. Makrostudier skildrer paradokser på organisasjonsnivå, for eksempel konkurranse og 
samarbeid, utvikling og drift samt stabilitet og endring. Mikrostudier på individ- og gruppenivå beskriver paradokser som effekt og nytte, selvfokus og andrefokus samt læring og gjennomføring (Schad et al., 2016). Paradokser oppstår altså på forskjellige organisatoriske nivåer. De kan oppstå som konflikter mellom styringsmodeller, målsettinger eller motstridende idealer for ledelsespraksis (Johansen, 2018, s. 13). Vi kan skille mellom dilemmaer og paradokser. Et dilemma er når det er snakk om innbyrdes konkurrerende valg, hvor hvert valg har sine fordeler og ulemper. Vi snakker om paradokser når mulighetene står mot hverandre og er relatert på den måten at et valg mellom dem kun er en midlertidig løsning, og der spenningene etter hvert vil dukke opp igjen (Smith \& Lewis, 2011). Det innebærer at et paradoks kan forstås som et dilemma som består over tid. Der hvor dilemmatenkningen legger opp til behov for prioritering og valgsituasjoner (som tradisjonelt er kjent for en leder), handler paradokstenkning mer om at man, som virksomhet og som leder, skal kunne forene det som umiddelbart framstår som uforenelige og gjensidig utelukkende handlemåter, såkalte umulige valgsituasjoner. Et bilde på dette er at lederen må klare å blåse og ha mel i munnen samtidig (Nielsen et al., 2018).

I litteraturen presenteres paradoksene som fire typologier som oppstår på ulike analysenivåer. De er paradokser knyttet til organisering, utførelse, tilhørighet og læring (Jarzabkowski, Lê \& Van de Ven, 2013, s. 247-248). Paradokstypologiene presenteres i figur 1.
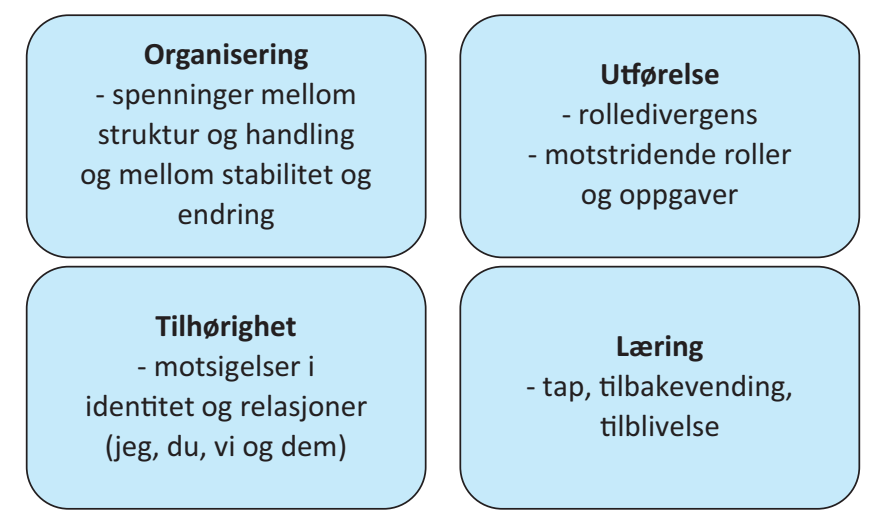

Figur 1 Paradokstypologier. Fire typer av organisatoriske paradokser. Modellen tar utgangpunkt i figur presentert i Johansen (2018, s. 97) 
Organiseringsparadokser handler om paradokser som oppstår gjennom måten vi velger å organisere oss på. Det vil være grensedragninger mellom dem som er henholdsvis innenfor og utenfor organisasjonen, og gjennom markering av interne skillelinjer. Spenninger oppstår mellom struktur og handling og mellom stabilitet og endring (Lüscher \& Lewis, 2008). Organiseringsparadokser utgjør rammen for de øvrige paradoksene. Utfordringen for lederne blir å finne den optimale organiseringen, hvor man kan dra fordeler av og minske ulempene ved spenningene som oppstår. Det vil være behov for å se på tvers av organisasjonens medlemmer og nivåer for å håndtere paradoksene (Johansen, 2018).

Utførelsesparadoksene tar for seg spenninger i krav og forventninger, eksemplifisert ved «når du kommer til krysset, går du til høyre og venstre». Gjennom motstridende roller og oppgaver opplever lederne paradokser knyttet til utførelse og innsats (Jarzabkowski et al., 2013; Lüscher \& Lewis, 2008; Smith \& Lewis, 2011). Det kan være ulike forventninger knyttet til adferd og resultater, det vil si motsigelser i det vi skal oppnå, og i måten vi skal oppnå det på. Ulike mål i form av både resultatmål og kvalitetsmål kan skape spenninger mellom mål man skal oppnå, og mellom hvilke midler man skal bruke for å oppnå dem. Et eksempel kan være at det ofte oppstår spenninger innen lederens hverdag knyttet til kvalitet på tjenestene som gis, og til den tiden man har til rådighet for å yte tjenesten. Mål er ofte av instrumentell karakter, noe som kan utfordre både samarbeid og kvaliteten på det faglige skjønnet som utøves (Johansen, 2018).

Ledere innen profesjonalisert velferd er nøkkelaktører i den formelle strukturen og har en nøkkelrolle i samarbeid med andre aktører, for eksempel helsesøster, skoler, leger og spesialisthelsetjenesten. Det betyr at lederne må navigere mellom ulike forventninger fra andre aktører i og rundt organisasjonen. De kan derfor oppleve rollekompleksitet og kan føle seg dradd mellom direktiver fra toppledelsen, bestillinger fra nøkkelinteressenter og perspektiver fra medarbeidere og samarbeidsparter (Johansen, 2018, s. 103). Lederne opplever ikke bare rollekompleksitet, men også rolledivergens. Forskjellige forventninger til organisasjonen lander hos ledere og medarbeidere, og ulike forventninger kan få lederne til å føle seg «strukket ut» mellom motstridende krav. Slike motstridende 
hensyn kan for eksempel være kontroll og autonomi, å bevare og skape innovasjon og å integrere og differensiere (Johansen, 2018, s. 118).

Tilhørighetsparadoksene handler om motsigelser i identitet og relasjoner: jeg, deg, vi og dem. Vi opplever tilhørighetsparadokser som spenninger koblet til de identitetene som bestemmer hvem vi er som organisasjoner og individer. Som leder og «fremst blant likemenn» kan lederen oppleve spenninger og motsetninger mellom ulike grupperinger, både i og utenfor sin organisasjon, og egen identitet og tilhørighet kan utfordres. Evnen til å utføre lederoppgaven vil derfor henge sammen med hvordan lederen ser seg selv i forhold til de ulike grupperingene. I lederhverdagen blir lederen satt i situasjoner hvor hun eller han må prioritere uten å velge side (Johansen, 2018). Det kan skje i samtaler med vedkommendes overordnede leder, medarbeidere eller samarbeidsparter. Det kan føre til paradoksale spenninger. Et eksempel kan være at lederens faglige innsikt og detaljkunnskap kan være verdifull for medarbeiderne, men kan utgjøre en utfordring for ledelsen på nivået over.

Læringsparadoksene handler om spenninger i oppfattelsen av tid. De er koblet til inngrodde motsigelser i tid - mellom fortid, nåtid, framtid - og til hvordan vi forbinder disse. Det er utfordrende å stabilisere og forandre organisasjonen samtidig. Læringsparadoksene er innkapslet i og går på tvers av organiserings-, utførelses- og tilhørighetsparadoksene (Jarzabkowski et al., 2013) og er basert på behovet for både å bygge på og «ødelegge» fortiden for å kunne bevege seg framover (Smith \& Lewis, 2011). Ofte må ledere sjonglere kravene til å ha både et kortsiktig og et langsiktig perspektiv på det man gjør. For ledere innen profesjonalisert velferd er tid en knapp ressurs (Andrews \& Gjertsen, 2014; Olsvik \& Saus, 2019), noe som kan føre til at man blir mer opptatt av den daglige driften og det kortsiktige perspektivet framfor organisasjonens langsiktige behov for utvikling. Motsetning mellom drift og utvikling vil kunne framstå som et paradoks.

Gjennomgangen av paradoksteorien viser at paradoksene er konkrete, og lederne opplever dem som spenninger i tanker og følelser. Det betyr at de motsetningene lederne opplever, er mentale forestillinger, og at det vi oppfatter som motsetninger, ikke nødvendigvis er det i virkeligheten (Kirkhaug, 2019). Paradoksene oppleves i tilknytning til 
ledernes arbeidsoppgaver, hvor roller og aktiviteter ofte er motsetningsfylte (Jarzabkowski \& Lê, 2017). Mange moderne ledelsesdilemmaer har karakter av paradokser fordi de ikke er spørsmål om å velge enteneller, men i økende grad om å håndtere både-og. Dette stiller særlige krav til lederen. Innen ledelse av profesjonalisert velferd eksisterer en del klassiske ledelsesdilemmaer. Disse har vært kjent over lengre tid og er sentrale organisasjons- og ledelsesutfordringer (Nielsen et al., 2018). Som eksempler kan nevnes pris versus kvalitet, autonomi versus samarbeid, kontroll versus fleksibilitet. Mange av de klassiske ledelsesdilemmaene har i økende grad fått karakter av å være paradokser snarere enn dilemmaer. Vi skal komme tilbake til hva dette innebærer for ledernes kompetanse.

Det finnes i dag lite forskning som gjelder ledelsesutfordringer og ledelse innen profesjonalisert velferd (Brock, Leblebici \& Muzio, 2014; Døving, Elstad \& Storvik, 2016; Muzio \& Kirkpatrick, 2011; Svensson \& Karlsson, 2008; Toresen, 2014). Det er derfor behov for forskning på hvordan ledere i praksis takler en motsetningsfylt virkelighet (Kirkhaug, 2015). En del av forskningen som finnes, er i stor grad rettet mot lederes faglige ledelse, hvor blant annet beslutninger i faglige spørsmål og faglig skjønn har vært vektlagt (Kvello \& Moe, 2014; Moe \& Gotvassli, 2016, 2017). Denne forskningen har stor verdi for å tydeliggjøre hvor kompleks profesjonalisert velferd er, og hvor utfordrende ledelse av dette feltet kan være. Ledere møter motstridende og konkurrerende krav i sin lederhverdag, og ved hjelp av paradoksteorien kan vi forstå og håndtere de spenningene som oppstår som følge av motstridende krav. Bruk av paradoksteori som utgangspunkt for å forstå både organisatoriske spenninger og lederutfordringer har økt i omfang (Schad et al., 2019). Forskning på paradokser innen organisasjon og ledelse finnes ikke bare innen ledelsesstudier, men også i interdisiplinære samfunnsvitenskapelige studier (Putnam, Fairhurst \& Banghart, 2016). Likevel viser en gjennomgang av forskningen på området, gjort av Schad et al. (2016) og Johansen (2018), at et paradoksteoretisk perspektiv i liten grad har vært brukt på ledelse av profesjonalisert velferd innen offentlig sektor. Når vi bruker paradoksteori for å forstå lederutfordringene innen profesjonalisert velferd, må vi klargjøre betingelsene for lederskapet, og 
hvilken sammenheng lederskapet utøves i. I neste del skal vi derfor ta for oss betingelser for ledelse av profesjonalisert velferd. Betingelsene rammer inn lederskapet og danner bakteppet når lederutfordringene skal beskrives.

\section{Lederskap innen profesjonalisert velferd Betingelser for ledelse av profesjonalisert velferd i en kommunal kontekst}

Ledelse i offentlig sektor framstilles ofte med noen særtrekk sammenlignet med ledelse i privat sektor (Jacobsen, 2019; Ospina, 2017; Van Wart, 2013). Offentlige organisasjoner er en del av samfunnets politiske organisasjon, noe som innebærer at ledelse i offentlig sektor foregår i en demokratisk kontekst (Busch, 2012). Ledere i kommunene forvalter offentliges ressurser, og de har dermed ansvar for å iverksette og nå de målene og strategiene som vedtas av våre folkevalgte. De handler på vegne av politisk valgte myndigheter og styres gjennom lov- og regelverk. Offentlige organisasjoner kan betegnes som multifunksjonelle (Christensen, Egeberg, Lægreid, Roness \& Røvik, 2015). Det innebærer at ledere i offentlige organisasjoner, for eksempel kommunen, skal ivareta delvis motstridende hensyn. Som leder må man forholde seg til politiske styringssignaler og kontroll, sørge for representasjon og deltakelse fra berørte parter samt medbestemmelse fra ansatte, ivareta brukermedvirkning, åpenhet, offentlighet og innsyn i beslutningsprosessene og sørge for forutsigbarhet, likebehandling, upartiskhet, nøytralitet, tjenestekvalitet, faglig uavhengighet og kostnadseffektivitet (Christensen et al., 2015). Dette kan vi beskrive som krav og begrensninger som påvirker de valgene lederne kan gjøre, og som dermed påvirker hvordan lederne opplever sitt handlingsrom. Handlingsrom kan defineres ved tre elementer: krav, begrensninger og valg (Espedal, 2008).

Handlingsrom avledes og påvirkes av miljømessige, organisatoriske og individuelle faktorer, for eksempel ledernes kunnskapsgrunnlag. Hver og en av faktorene kan hemme eller muliggjøre strategiske handlinger i organisasjonen (Finkelstein \& Peteraf, 2007; Kakabadse, Lee-Davies \& 
Kakabadse, 2009; Torsteinsen, 2017). Ergo kan vi betrakte handlingsrom som en organisasjonsmessig arena hvor ledelsen har frihet, skjønn, makt og legitimitet til å kunne fatte beslutninger og handle ut fra fullmakter og mandater.

En viktig dimensjon ved offentlig sektor er at virksomheten er preget av de overordnede målene om velferd, sosial likhet og rettferdighet, i tillegg til at den enkelte sektor eller virksomhet har sine krav og verdier. I vår kontekst vil slike verdier være blant annet omsorg, ivaretagelse av barn og unge og brukermedvirkning. Ledelse av profesjonalisert velferd foregår i en normativ kontekst (Høst, 2014; Sullivan, 2016), og lederne må forholde seg til normative krav. «God omsorg» og «barnas beste» er begge normative begreper som vi kjenner igjen som kvalitetsmål innenfor vår kontekst, men det er ofte vanskelig å måle hvorvidt normative mål for tjenesten er nådd. Tjenestene som ytes, krever stor grad av skjønnsbruk ved at tilbud skal tilpasses hvert enkelt individ, men det stilles samtidig krav om at tjenester skal rasjoneres og tildeles i tråd med gjeldende lover og regler (Vabø, 2007). Ofte må tøffe prioriteringer gjøres, noe som stiller store krav til ledelse. Skjønnsbruken utfordres ved at ledere i offentlig sektor opplever mindre rom for bruk av skjønn og større grad av rollekonflikter enn ledere i andre organisasjoner (Jacobsen, 2019, s. 144).

Utviklingen innen offentlig virksomhet har de siste tretti årene vært preget av NPM (Busch, 2012; Christensen, 2012; Shanks et al., 2015). Det har ført til økt vekt på konkurranse, resultatmålinger og ansvarliggjøring samt sterkere styring og mer oppmerksomhet på tjenestemottakerne. Offentlig sektor har blitt mer kompleks og utfordrende, og det etterspørres økt åpenhet og brukermedvirkning (Jacobsen, 2019; Klausen, 2001). Utviklingen har også ført til et økt oppmerksomhet på ledelse og lederkompetanse. Ledelse av både helse- og omsorgstjenester og barnevern er viet stor nasjonal politisk oppmerksomhet de senere årene og er omtalt i en rekke offentlige dokumenter. Blant disse kan vi trekke fram Meld. St. 26 (2014-2015) (Helse- og omsorgsdepartementet, 2015) om primærhelsetjenesten og Meld. St. 13 (2016-2017), Kvalitet og pasientsikkerhet (Helse- og omsorgsdepartementet, 2016). I tillegg framkommer tydelige krav i forskrift om ledelse og kvalitetsforbedring i helse- og 
omsorgstjenesten (2016), hvor lederfunksjonens ansvar og plikter understrekes. Tilsvarende ser vi for barnevernsektoren, og vi kan trekke fram kompetansestrategi for det kommunale barnevernet (Barne- og likestillingsdepartementet, 2017a), beskrivelse av krav og forventninger til operativ ledelse i barnevernet (Barne-, ungdoms- og familiedirektoratet [Bufdir], 2017) og endringer i barnevernloven (Barne- og likestillingsdepartementet, 2017b). I de nevnte dokumentene kommer det tydelig fram at krav og forventninger til ledelse av disse sektorene har blitt vektlagt $\mathrm{i}$ $ø$ kende grad. Betingelsene for ledelse av profesjonalisert velferd kan oppsummeres i følgende kulepunkter:

- Ledelse foregår i en demokratisk kontekst.

- Ledere forvalter det offentliges ressurser.

- Ledelse foregår i en normativ kontekst, med normative krav.

- Ledelse krever stor grad av skjønnsbruk.

- Økte krav og forventninger til ledelse og lederkompetanse.

\section{Ledelsesutfordringer: motstridende krav og paradokser}

Ledelse av profesjonalisert velferd beskrives ofte som full av motsigelser og dilemmaer (Høst, 2014). Sykepleiere i ledende stillinger opplever krysspress og motstridende forventninger fra ulike parter. Blant annet stiller lokale og nasjonale myndigheter krav til den kommunale helse- og omsorgstjenesten som er vanskelige å etterkomme. Eksempler som gis fra ledende sykepleiere, er manglende tid til nytenkning og strategisk arbeid. Det stilles krav om langsiktig tenkning og igangsetting av endringsprosesser, men dette lar seg vanskelig gjennomføre i en hverdag hvor man mangler kvalifisert personell og samtidig skal sørge for forsvarlig drift (Andrews \& Gjertsen, 2014). Barnevernledere beskriver sin lederhverdag som krevende, følelsesladet og uforutsigbar med hyppige oppmerksomhetsskifter (Olsvik \& Saus, 2019), og det kan sies at de har en lederhverdag som er utfordrende og sammensatt (Moe \& Gotvassli, 2016). Colby Peters (2018, s. 32) peker på tre ting som kjennetegner ledelse innen profesjonalisert velferd: 
1) Lederskapet inneholder et sterkt følelsesmessig aspekt, og det bygger i stor grad på samarbeid med andre.

2) I tillegg er lederskapet styrt av formålet med tjenestene, som er å sørge for individuell og samfunnsmessig velferd. Dermed handler det også om å implementere og følge opp statlige og organisatoriske retningslinjer og pålegg (Popa, 2012). På den måten utsettes lederen for et krysspress mellom ulike normative krav.

3) Det stilles i tillegg krav om gjennomføring av oppgaver på en effektiv måte samt om oppnåelse av ønskede resultater.

Lederen har det helhetlige ansvaret for tjenesten, det vil si ansvar for både økonomi, personal og faglig utvikling. Innen profesjonalisert velferd har lederrollen vært preget av en fagstyretradisjon, hvor høyt utdannede personer har fått mandat og ressurser til å utøve faget på best mulig måte (Høst, 2014; Sullivan, 2016). Lederen har dermed hatt rollen som både saksbehandler, ekspert, tilrettelegger og veileder, og man har framstått som «fremst blant likemenn» (Høst, 2014; Toresen, 2014). I barnevernet ser vi at skjønnsutøvelsen i forkant av beslutninger ofte utføres som en kollektiv prosess (Olsvik \& Saus, 2019). I mange sammenhenger vil man derfor oppfatte seg som både leder og kollega, noe som kan føre til at man blir utsatt for forskjellige og ofte motstridende forventninger og krav fra de to gruppene.

Over tid har vi sett en forflytning av ansvar og oppgaver fra statlig nivå til kommunenivå (Oterholm, 2016). Det har ført til at lederne innen profesjonalisert velferd skal ivareta et vidt spenn av krav og hensyn. Lederne opplever ofte krysspress i form av motstridende forventninger og krav internt fra andre ledere og kollegaer samt fra nasjonale føringer overfor tjenesten. Krysspresset mellom ulike styringskrav pekes på av flere (Agevall, 20oo; Gaim \& Wåhlin, 2016; Hood, 1991; Hood \& Peters, 2004; Kirkhaug, 2015; Kvello \& Moe, 2014; Pettersen \& Solstad, 2014; Wällstedt \& Almqvist, 2015). Et eksempel på krysspress kan være at økonomiske rammer og rapporteringskrav ikke alltid oppleves som forenelig med etiske og profesjonelle hensyn. I dette krysspresset oppstår gjerne dilemmaer, noe som gjør at lederens hverdag ofte preges av kompleksitet, usikkerhet og belastninger (Andrews \& Gjertsen, 2014; Høst, 2014; Moe \& Gotvassli, 2016, s. 196-197; Sullivan, 2016). 
Ledelsesutfordringene i helse- og omsorgstjenester og barnevern kan oppsummeres i følgende kulepunkter:

- motstridende forventninger fra ulike parter

- krevende og uforutsigbar lederhverdag

- krysspress mellom normative krav

- utfordrende lederrolle - leder eller kollega

- økt ansvar og flere oppgaver

\section{Lederkompetanse - hva kreves?}

Som allerede beskrevet innebærer ledelse av profesjonalisert velferd en lederhverdag som er motsetningsfylt, og hvor krysspresset mellom ulike forventninger og styringskrav skaper spenninger. Dette utfordrer lederkompetansen på flere områder. Hvilken kompetanse kreves av lederne i en slik motsetningsfylt og kompleks lederhverdag?

Kompetanse kan defineres som de samlede kunnskapene, ferdighetene, evnene og holdningene som gjør det mulig å utføre aktuelle funksjoner og oppgaver i tråd med definerte krav og mål (Lai, 2004). Hva som er relevant kompetanse for ulike funksjoner i en organisasjon, er påvirket av institusjonelle normer og holdninger. Lederkompetanse definerer Yukl (2013) som kunnskaper, ferdigheter, evner og holdninger som er relatert til å oppnå mål gjennom andre personer. Døving (2016) opererer med ulike typer lederkompetanse: analytisk, sosial, kontekstuell og faglig. Det understrekes at den gode lederen i en profesjonell organisasjon har en samlet kompetanse som består av ulike delkompetanser, og disse delene utfyller hverandre. Fagkompetanse og kontekstuell kompetanse innenfor kjerneaktivitetene helse og omsorg og barnevern er sentrale delkompetanser som gir lederen legitimitet blant de profesjonelle. Sammen med analytisk, sosial og styringsfaglig kompetanse utgjør fagkompetansen og den kontekstuelle kompetansen den helhetlige lederskapskompetansen. Derav defineres ofte lederen innen profesjonalisert velferd som en hybridleder. Dette er en leder som kan agere både på profesjonens arena og på den generelle administrative arenaen (Døving, 2016). 
Krav og forventninger til ledere av profesjonalisert velferd er mange og kan oppfattes motsetningsfylte. Dersom vi tar utgangspunkt i den faglige anbefalingen fra Barne-, ungdoms- og familiedirektoratet (Bufdir), hvor krav og forventninger til operativ ledelse i barnevernet beskrives (Bufdir, 2017), ser vi at det er en klar forventning om at lederrollen profesjonaliseres gjennom blant annet en tydeliggjøring av ledernes rolleforståelse og en styrking av lederkompetansen. Det forventes at barnevernleder har juridisk kompetanse, ivaretar prinsippene om forsvarlighet, forutberegnelighet og gjennomsiktighet, praktiserer en effektiv og tydelig ledelse samt utøver en profesjonell skjønnsutøvelse som er rettslig forankret. Den faglige anbefalingen identifiserer seks hovedoppgaver for ledelse i barnevernet: barnevernledelse, fagledelse, strategiledelse, personalledelse, økonomiledelse og offentlig ledelse (Bufdir, 2017). Ut fra kjennskap til lederhverdagen til barnevernlederne ser vi at det ligger til rette for at paradoksale spenninger kan oppstå (Kvello \& Moe, 2014; B. S. Olsvik \& Saus, 2020). For mange vil forventningene om å arbeide strategisk med langsiktige drifts-, tilpasnings- og utviklingsmål og samtidig gjøre en pragmatisk budsjettmessig prioritering, hvor barn i størst risiko sikres optimal bistand først (Bufdir, 2017, s. 10), kunne utløse paradoksale og motsetningsfylte situasjoner.

Tilsvarende forventninger stilles til ledere i helse- og omsorgssektoren. I dokumentet Omsorg 2020. Regjeringens plan for omsorgsfeltet 2015-2020 (Helse- og omsorgsdepartementet, 2015) understrekes betydningen av $ø$ kt styring og ledelse. Det stilles store krav til lederne, og forventningene er mange. Følgende setning sier noe om forventninger til tjenestene, og om hvilket ansvar som hviler på lederne: «Tjenestene skal drives effektivt og innovativt tilpasset pasienter og brukeres behov, i kombinasjon med å være inspirerende og rekrutteringsattraktive fagmiljøer» (Helse- og omsorgsdepartementet, 2015, s. 9). Det forventes at lederne sørger for helhetlig og koordinert samhandling mellom de ulike tjenesteområdene, legger til rette for brukermedvirkning, vektlegger forsvarlighet i tjenestene og har kunnskaper om de formelle mulighetene og virkemidlene til utøvelse av ledelse. Forventinger om fornyelse og innovasjon, endret og høyere kompetanse, nye arbeidsmetoder og nye faglige tilnærminger preger lederhverdagen til lederne i helse- og omsorgssektoren. Kombinasjonen 
av ulike krav framstår ofte motsetningsfylt og utgjør grunnlag for paradoksale spenninger.

\section{Lederskap med paradoksale spenninger krever dilemmakompetanse}

Krav og forventninger til lederne av profesjonalisert velferd er altså mange og ofte preget av paradokser. Paradoksene kommer særlig fram i en omverden hvor det oppstår knapphet, hvor hverdagen er preget av forandringer, eller hvor vi befinner oss i sammenhenger med stort mangfold i institusjonelle logikker, aktører og krav, det vil si at det er mange ulike spilleregler som lederne må forholde seg til (Johansen, 2018, s. 19; Smith \& Lewis, 2011). Knapphet kan gjelde for eksempel økonomi, personell, tid og kompetanse. Det er en utfordring for mange ledere å få tid til å lede (Andrews \& Gjertsen, 2014; Andrews \& Høgås, 2017; Olsvik \& Saus, 2020). Ofte er mange ledere også saksbehandlere og er langt inne i faglige saker. Man må altså være både en dyktig fagperson og en tydelig leder. Men ledelse er mer enn å være en dyktig fagperson. Mange hevder at ledelse har sin egen faglighet (Nielsen et al., 2018). Når lederen utelukkende henter sin faglighet og identitet fra den fagligheten og profesjonen som utgjør basis i virksomheten, blir ledelsesfagligheten undertrykket. Vi ser at det i mange profesjonelle virksomheter, for eksempel innen profesjonalisert velferd, er særlig vanskelig å prioritere det ledelsesfaglige fordi den faglige kulturen og oppmerksomheten er så sterk (Nielsen et al., 2018, s. 37-38).

Knapphet kan også handle om kompetanse, både hos lederen selv og hos medarbeiderne. I en motsetningsfylt lederhverdag har lederne behov for kompetanse for å håndtere paradoksene. Slik kompetanse kan benevnes dilemmakompetanse, som innebærer kunnskap om at paradoksene er til stede, samt strategier for å kunne leve med paradoksene. Basert på Lai (2004) sin definisjon av kompetanse kan dilemmakompetanse forstås som kunnskap om paradoksale spenninger. Det vil innebære at man utvikler ferdigheter, både praktiske og analytiske, til å håndtere paradoksene i den praktiske lederhverdagen. Man må i større grad kunne møte paradoksale situasjoner og spenninger med grundighet og troverdighet, og med en innstilling om at det er mulig å lede i paradoksale situasjoner. 
Utvikling av dilemmakompetanse krever et prosessuelt perspektiv. Dette bidrar til forståelse av dynamiske forhold mellom motstridende krefter (Fairhurst et al., 2016), og det hjelper lederne til å bli oppmerksom på hvordan hvert av elementene i det som oppfattes som et paradoks, kontinuerlig informerer og definerer hverandre. Det prosessuelle perspektivet hjelper lederne til å rette oppmerksomheten på hvordan deres respons på paradokser konstrueres i lederhverdagen, heller enn at de retter mest oppmerksomhet på hvordan de reagerer på paradoksene. Lederens håndtering av paradokser handler om en pågående prosess som kan beskrives som «coping with» eller «working through» paradokser (Jarzabkowski \& Lê, 2017). Paradokser virker på to måter: De kan framkalle handlingslammelse og ubesluttsomhet, og de kan fremme kreativitet og innovasjon (Nielsen et al., 2018). For å kunne håndtere paradokser i hverdagen bør lederne øve seg i paradokstenkning. Paradokstenkning hjelper oss til kompleksitetshåndtering snarere enn til kompleksitetsreduksjon, og den vil kunne bidra til utvidelse av det subjektive handlingsrommet til lederne (Espedal \& Kvitastein, 2012). Når lederhverdagen er kompleks, ønsker vi oss ofte forenkling, standardisering og ensretting (Nielsen et al., 2018), siden dette oppleves som enklere å forholde seg til og kontrollere. Men spørsmålet er om resultatet blir det man ønsker, eller om man bare oppnår en midlertidig følelse av trygghet.

\section{Oppsummering}

Vi har i dette kapitlet beskrevet hva som utgjør noen av ledelsesutfordringene innen profesjonalisert velferd. Vi har anvendt et paradoksteoretisk perspektiv for å forklare disse utfordringene, og vi har belyst hvilken kompetanse som kreves av ledere som utsettes for paradoksale spenninger i lederhverdagen. Det er ikke en ny oppdagelse at ledelse inneholder dilemmaer og paradokser. Det som er nytt, er mengden av dem, og at prioriteringer og ledelsesbeslutninger stadig krever endringer og justeringer. Dette understreker behovet for et paradoksperspektiv på ledelse. En gjennomgang av krav og forventninger til lederne innen profesjonalisert velferd viser at lederne både strategisk og praktisk må forholde seg til en stadig økende kompleksitet. Her kan paradoksteorien hjelpe oss å skape 
et overblikk over motstridende perspektiver. Det gir også mening å se på lederskap som en kompleks, paradoksal og situasjonsbetinget funksjon (Kirkhaug, 2015). Yukl (2013) fremhever at ledelse må tilpasses omstendighetene. Det betyr at også lederkompetansen må tilpasses omstendighetene, noe som kan være utfordrende i en lederhverdag som utfordres av knapphet, forandringer og et stort mangfold i institusjonelle logikker. Tid er ofte en knapphetsfaktor, og det handler ikke bare om mangel på tid til å lede. Det handler like mye om mangel på tid til å utvikle sin kompetanse og til å øve seg i paradokstenkning og kompleksitetshåndtering for nettopp å bli bedre på å leve med og arbeide seg gjennom paradoksale spenninger.

\section{Referanser}

Agevall, L. (2000). Hur välfärd organiseras - Spelar det någon roll? Statsvetenskaplig tidskrift, 103(1), 18-42.

Andrews, T. \& Gjertsen, H. (2014). Sykepleieledere og ledelse (NF-rapport nr. 4/2014). http://www.nordlandsforskning.no/getfile.php/133583-1413465931/Dokumenter/ Rapporter/2014/NF-rapport\%204_14.pdf

Andrews, T. \& Høgås, J. (2017). Vilkår for ledelse. Om økonomi, kompetanse, ansvar og myndighet $i$ norske helse- og omsorgstjenester (NF-rapport nr. 10/2017). http:// www.nordlandsforskning.no/getfile.php/1319733-1510135519/Dokumenter/ Rapporter/2017/NF-rapport\%2010_2017.pdf

Barne- og likestillingsdepartementet. (2017a). Mer kunnskap - bedre barnevern. Kompetansestrategi for det kommunale barnevernet 2018-2024. Hentet fra https:// www.regjeringen.no/contentassets/6e31905299774f5681d57311e284d519/bedrebarnevern.pdf

Barne- og likestillingsdepartementet. (2017b). Endringer i barnevernloven (barnevernsreform) (Prop. 73 L. (2016-2017)). Hentet fra https://www.regjeringen. no

Barne-, ungdoms- og familiedirektoratet. (2017). Operativ ledelse i barnevernet. Beskrivelse av krav og forventninger. Hentet fra https://bufdir.no/bibliotek/ dokumentside/?docid=bufoooo4003

Brock, D. M., Leblebici, H. \& Muzio, D. (2014). Understanding professionals and their workplaces: The mission of the Journal of Professions and Organizations. Journal of Professions and organizations, 1(1), 1-15. https://doi.org/10.1093/jpo/ jotoo6

Busch, T. (2012). Verdibasert ledelse i offentlige profesjoner. Bergen: Fagbokforlaget. 
Christensen, T. (2012). Post-NPM and changing public governance. Meiji Journal of Political Sciences and Economics, 1(1), 1-11.

Christensen, T., Egeberg, M., Lægreid, P., Roness, P. G. \& Røvik, K. A. (2015). Organisasjonsteori for offentlig sektor (3. utg.). Oslo: Universitetsforlaget.

Colby Peters, S. (2018). Defining social work leadership: a theoretical and conceptual review and analysis. Journal of Social Work Practice, 32(1), 31-44. https://doi.org/1 $0.1080 / 02650533.2017 .1300877$

Crosby, B. C. \& Bryson, J. M. (2018). Why leadership of public leadership research matters: and what to do about it. Public Management Review, 2o(9), 1265-1286. https://doi.org/10.1080/14719037.2017.1348731

Døving, E. (2016). Fagfolk og generalister som ledere i profesjonelle organisasjoner. I E. Døving, B. Elstad \& A. Storvik (Red.), Profesjon og ledelse (s. 255-276). Bergen: Fagbokforlaget.

Døving, E., Elstad, B. \& Storvik, A. (Red.). (2016). Profesjon og ledelse. Bergen: Fagbokforlaget.

Espedal, B. (2008). Handlingsrom for ledelse. Beta, 22(2), 20-38.

Espedal, B. \& Kvitastein, O. A. (2012). Rom for læring: Betydningen av handlingsrom for ledelse. Magma - Tidsskrift for økonomi og ledelse, 15(8), 30-39.

Fairhurst, G. T., Smith, W. K., Banghart, S. G., Lewis, M. W., Putnam, L. L., Raisch, S. \& Schad, J. (2016). Diverging and converging: Integrative insights on a paradox meta-perspective. Academy of Management Annals, 10(1), 173-182. https://doi.org/ https://doi.org/10.5465/19416520.2016.1162423

Fiedler, F. E. (1967). A theory of leadership effectiveness. New York: McGraw-Hill.

Finkelstein, S. \& Peteraf, M. A. (2007). Managerial activities: A missing link in managerial discretion theory. Strategic Organization, 5(3), 237-248. https://doi. org/10.1177/1476127007079975

Forskrift om ledelse og kvalitetsforbedring i helse- og omsorgstjenesten. (2016). Forskrift om ledelseog kvalitetsforbedring i helse- og omsorgstjenesten (FOR-2016-10-28-1250). Hentet fra https://lovdata.no/dokument/SF/ forskrift/2016-10-28-1250

Fossum, S., Lauritzen, C., Vis, S. A. M., Ottosen, A. \& Rustad, K. B. (2015). Samhandling mellom barnevern og psykisk helsevern for barn og unge - en litteraturgjennomgang. Tidsskriftet Norges barnevern, 92(4), 282-297.

Gaim, M. \& Wåhlin, N. (2016). In search of a creative space: A conceptual framework of synthesizing paradoxical tensions. Scandinavian Journal of Management, 32(1), 33-44. https://doi.org/https://doi.org/10.1016/j. scaman.2015.12.002

Helse- og omsorgsdepartemetnet. (2009). Samhandlingsreformen - Rett behandling på rett sted - til rett tid (St.meld. nr. 47 (2008-2009)). Hentet fra https://www. regjeringen.no 
Helse- og omsorgsdepartementet. (2015). Omsorg 2020. Regjeringens plan for omsorgsfeltet 2015-2020. Hentet fra https://www.regjeringen.no/contentassets/ af2a24858c8340edaf78a77e2fbegcb7/omsorg_2020.pdf

Hersey, P. \& Blanchard, K. H. (1988). Management of organizational behavior: utilizing human resources (5. utg.). Englewood Cliffs, NJ: Prentice Hall.

Hood, C. (1991). A public management for all seasons? Public Administration, 69(1), 3-19. https://doi.org/10.1111/j.1467-9299.1991.tboo779.x

Hood, C. \& Peters, G. (2004). The middle aging of New Public Management: Into the age of paradox? Journal of Public Administration Research and Theory, 14(3), 267-282. https://doi.org/https://doi.org/10.1093/jopart/muho19

Høst, T. (2014). Ledelse i helse- og sosialsektoren (3. utg.). Oslo: Universitetsforlaget. Jacobsen, D. I. (2019). Ledelse og den offentlige dimensjon. En sammenligning av ledere i offentlige og private organisasjoner. Bergen: Fagbokforlaget.

Jarzabkowski, P. \& Lê, J. K. (2017). We have to do this and tat? You must be joking: Constructing and responding to paradox through humor. Organization Studies, 38(3-4), 433-462. https://doi.org/10.1177/0170840616640846

Jarzabkowski, P., Lê, J. K. \& Van de Ven, A. H. (2013). Responding to competing strategic demands: How organizing, belonging, and performing paradoxes coevolve. Strategic Organization, 11(3), 245-28o. https://doi. org/10.1177/1476127013481016

Johansen, J. H. (2018). Paradoksledelse. Jagten på vordi i kompleksitet. København: Jurist- og Økonomforbundets Forlag.

Kakabadse, N. K., Lee-Davies, L. \& Kakabadse, A. (2009). Leadership discretion: A developmental experience. Strategic Change, 18(3-4), 111-124. https://doi. org/10.1002/jsc. 842

Kirkhaug, R. (2015). Lederskap. Person og funksjon. Oslo: Universitetsforlaget.

Kirkhaug, R. (2019). Lederskap. Person og funksjon (2. utg.). Oslo: Universitetsforlaget.

Klausen, K. K. (2001). Skulle det voere noget saerligt? Organisation og ledelse i det offentlige. København: Børsen forlag.

Knight, E. \& Paroutis, S. (2017). Becoming salient: The TMT leader's role in shaping the interpretive context of paradoxical tensions. Organization Studies, 38(3-4), 403-432. https://doi.org/10.1177/0170840616640844

Kvello, Ø. \& Moe, T. (Red.). (2014). Barnevernledelse. Oslo: Gyldendal Akademisk. Lai, L. (2004). Strategisk kompetansestyring (2. utg.). Bergen: Fagbokforlaget. Lewis, M. W. \& Smith, W. K. (2014). Paradox as a metatheoretical perspective: Sharpening the focus and widening the scope. Journal of Applied Behavioral Science, 5o(2), 127-149. https://doi.org/10.1177/0021886314522322 
Lüscher, L. S. \& Lewis, M. W. (2008). Organizational change and managerial sensemaking: Working through paradox. Academy of Management Journal, 51(2), 221-240. https://doi.org/10.5465/AMJ.2008.31767217

Helse- og omsorgsdepartementet. (2016). Kvalitet og pasientsikkerhet 2015 (Meld. St. 13 (2016-2017)). Hentet fra https://www.regjeringen.no.

Helse- og omsorgsdepartementet. (2015). Fremtidens primoerhelsetjeneste - noerhet og helhet (Meld. St. 26. (2014-2015)). Hentet fra https://www.regjeringen.no.

Moe, T. \& Gotvassli, K.-Å. (2016). Ledelse og beslutningspraksis. I Ø.

Christiansen \& B. H. Kojan (Red.), Belutninger i barnevernet (s. 195-213). Oslo: Universitetsforlaget.

Moe, T. \& Gotvassli, K.-Å. (2017). Barnevernledelse - skjønnsutøvelse og ansvarliggjøring. I O. J. Andersen, T. Moldenæs \& H. Torsteinsen (Red.), Ledelse og skjønnsutøvelse (s. 132-155). Bergen: Fagbokforlaget.

Muzio, D. \& Kirkpatrick, I. (2011). Introduction: Professions and organizations a conceptual framework. Current Sociology, 59(4), 389-405. https://doi. org/10.1177/0011392111402584

Nielsen, R. K., Hjalager, A.-M., Larsen, H. H., Bévort, F., Henriksen, T. D. \& Vikkelsø, S. (Red.). (2018). Ledelsesdilemmaer - og kunsten at navigere i moderne ledelse. København: Djøf forlag.

Olsvik, B. S. \& Saus, M. (2019). Skjønn i praktisk barnevernledelse. Kollektiv prosess med organisatoriske begrensninger. Tidsskriftet Norges barnevern, 96(4), 262-282.

Olsvik, B. S. \& Saus, M. (2020). Coping with paradoxes: Norwegian child welfare leaders managing complexity. Child Care in Practice, Hentet fra https://www. tandfonline.com/doi/full/10.1080/13575279.2020.1776683

Orazi, D. C., Turrini, A. \& Valotti, G. (2013). Public sector leadership: New perspectives for research and practice. International Review of Administrative Sciences, 79(3), 486-504. https://doi.org/10.1177\%2Foo20852313489945

Ospina, S. M. (2017). Collective leadership and context in public administration: Bridging public leadership research and leadership studies. Public Administration Review, 77(2), 275-287. https://onlinelibrary.wiley.com/doi/abs/10.1111/puar.12706

Oterholm, I. (2016). Kompetanse til arbeid i barneverntjenesten - ulike aktørers synspunkter. Norges barnevern, 93(3-4), 146-164. https://doi.org/10.18261/ issn.1891-1838-2016-03-04-02

Pettersen, I. J. \& Solstad, E. (2014). Managerialism and profession-based logic: The use of accounting information in changing hospitals. Financial Accountability \& Management, 3o(4).

Ponnert, L. \& Svensson, K. (2016). Standardisation - the end of professional discretion? European Journal of Social Work, 19(3-4), 586-599. https://doi.org/10.1 o8o/13691457.2015.1074551 
Popa, A. B. (2012). A quantitative analysis of perceived leadership practices in child welfare organizations. Journal of Public Child Welfare, 6(5), 636-658. https://doi.or g/10.1080/15548732.2012.723974

Putnam, L. L., Fairhurst, G. T. \& Banghart, S. (2016). Contradictions, dialectics, and paradoxes in organizations: A constitutive approach. Academy of Management Annals, 10(1), 65-171. https://doi.org/https://doi.org/10.108o/19416 520.2016.1162421

Schad, J., Lewis, M. W., Raisch, S. \& Smith, W. K. (2016). Paradox research in management science: Looking back to move forward. Academy of Management Annals, 10(1), 5-64. https://doi.org/https://doi.org/10.108o/19416520.2016.1162422

Schad, J., Lewis, M. W. \& Smith, W. K. (2019). Quo vadis, paradox? Centripetal and centrifugal forces in theory development. Strategic Organization, 17(1), 107-119. https://doi.org/https://doi.org/10.1177\%2F1476127018786218

Shanks, E., Lundström, T. \& Wiklund, S. (2015). Middle managers in social work: Professional identity and management in a marketised welfare state. British Journal of Social Work, 45(6), 1871-1887. https://doi.org/10.1093/bjsw/bcuo61

Smith, W. K. \& Lewis, M. W. (2011). Toward a theory of paradox: A dynamic equilibrium model of organizing. Academy of Management Review, 36(2), 381-403. https://doi.org/10.5465/amr.2009.0223

Stacey, R. \& Griffin, D. (Red.). (2006). Complexity and the experience of managing in public sector organizations. London: Routledge.

Sullivan, W. P. (2016). Leadership in social work: Where are we? Journal of Social Work Education, 52(sup1), 551-561. https://doi.org/10.1080/10437797.2016.1174644

Svensson, L. G. \& Karlsson, A. (2008). Profesjoner, kontroll og ansvar. I A. Molander \& L. I. Terum (Red.), Profesjonsstudier (s. 261-278). Oslo: Universitetsforlaget.

Thagaard, T. (2016). Systematikk og innlevelse. En innføring i kvalitativ metode. (4. utg.). Bergen: Fagbokforlaget.

Toresen, G. (2014). Barnevernlederen - et kommunalt kinderegg? I T. Moe \& $\varnothing$. Kvello (Red.), Barnevernledelse. Oslo: Gyldendal akademisk.

Torsteinsen, H. (2017). Ledere som pragmatiske instrumentalister. I O. J. Andersen, T. Moldenæs \& H. Torsteinsen (Red.), Ledelse og skjønnsutøvelse (s. 75-92). Bergen: Fagbokforlaget.

Uhl-Bien, M. \& Arena, M. (2018). Leadership for organizational adaptability: A theoretical synthesis and integrative framework. The Leadership Quarterly, 29(1), 89-104. https://doi.org/https://doi.org/10.1016/j.leaqua.2017.12.009

Vabø, M. (2007). Organisering for velferd. Hjemmetjenesten i en styringsdeologisk brytningstid (NOVA-rapport 22/2007). Oslo: Norsk institutt for forskning om oppvekst, velferd og aldring.

Van Wart, M. (2013). Administrative leadership theory: A reassessment after 10 years. Public Administration, 91(3), 521-543. https://onlinelibrary.wiley.com/doi/ abs/10.1111/padm.12017 
Vik, E. (2018). Helseprofesjoners samhandling - en litteraturstudie. Tidsskrift for velferdsforskning, 21(2), 119-147. https://doi.org/10.18261/issn.2464-3076-2018-02-03

Wällstedt, N. \& Almqvist, R. (2015). From 'either or' to 'both and': Organisational management in the aftermath of NPM. Scandinavian Journal of Public Administration, 19(2), 7-25.

Yukl, G. A. (2013). Leadership in organizations (8. utg.). Essex, England: Pearson. Aaltvedt, V., Juvland, L. \& Öresland, S. (2017). Omsorgsdiskurs og budsjettstyringsdiskurs - to konstituerende diskurser som konstruerer lederskap i hjemmetjenesten. Nordisk sygeplejeforskning, 7(3), 209-223. https://doi. org/10.18261/issn.1892-2686-2017-03-04 



\title{
KAPITTEL 6
}

\section{Utøvelse av ledelse i kommunale sykehjem - handlingsrommets betydning}

\author{
Bente Lilljan Lind Kassah, Hilde Nordahl-Pedersen \\ og Wivi-Ann Tingvoll ${ }^{1}$ \\ UiT Norges arktiske universitet
}

\begin{abstract}
Leaders of municipal nursing homes face challenges when they seek to secure a balance between the quality demands of authorities and the services they provide. In this chapter, we present a qualitative study on the leadership challenges in the municipal nursing homes. The aim is to develop knowledge on leadership challenges and the managerial discretions leaders employ to address the challenges. We interviewed seven middle-level leaders in five nursing homes in three medium-sized Norwegian municipalities using semi-structured interviews. The study revealed challenges connected to temporal nursing home placements made permanent, the time-consuming nature of the search for substitute workers, and the need to improve worker attitudes towards substitute workers' experience-based knowledge. Attitude change is necessary because different forms of knowledge have different statuses in the nursing homes. The study shows that the leaders seek to meet the challenges connected to nursing home placements by establishing teams of professionals, while they try to persuade the Specialist Health Services to take over the responsibilities for the patients in transition. To meet the substitute worker challenge, the leaders use subjective managerial discretions to develop different strategies, including establishing substitute worker bases, substitute worker lists and delegation of substitute worker search. The leaders promote attitude change by stressing the importance of the substitute workers' experience-based knowledge in both formal and informal contexts and implementing concrete competence measures. The study indicates that leaders who use subjective managerial discretions save time that they employ to create a balance
\end{abstract}

$1 \quad$ Forfatterne er likeverdige bidragsytere.

Sitering av denne artikkelen: Kassah, B. L. L., Nordahl-Pedersen, H. \& Tingvoll, W.-A. (2020). Utøvelse av ledelse i kommunale sykehjem - handlingsrommets betydning. I B. L. L. Kassah, H. Nordahl-Pedersen \& W.-A. Tingvoll (Red.), Handlingsrom for profesjonalisert velferd: Kommunale tjenester for helse, omsorg og barnevern (Kap. 6, s. 131-153). Oslo: Cappelen Damm Akademisk. https://doi.org/10.23865/noasp.114.ch6 Lisens: CC-BY 4.o. 
between different leadership functions. The use of managerial discretions by leaders may affect the learning and organizational changes in nursing homes.

Keywords: nursing home, management, managerial discretion, knowledge, attitude, organizational challenges

\section{Introduksjon}

Den kommunale helse- og omsorgstjenesten har siden 1980-årene hatt New Public Management (NPM) som styrende prinsipp, og det legges vekt på kostnadseffektivitet, resultatoppnåelse, kvalitetsmåling og brukertilfredshet (Hernes, 2007; Lian, 2007; Kaplan \& Norton, 1996; Rasmussen, 2011). NPM og andre større reformer (Helse- og omsorgsdepartementet, 2009; Helse- og omsorgsdepartementet, 2015) har ført til økt oppmerksomhet på økonomi, gitt flere administrative oppgaver i helsetjenesten, og ifølge Wyller og Hauklien (2017) har denne utviklingen gått på bekostning av ledelse. Mange kommuner møter ledelsesutfordringer når de skal ivareta ansvaret for samsvar mellom myndighetenes krav til kvalitet og de tjenestene som tilbys (Helse- og omsorgsdepartementet, 2016). Ledelse i kommunal helsetjeneste er viktig fordi den har betydning for arbeidsmiljø, kompetanseheving, motivasjon, trivsel og sykefravær (Helse- og omsorgsdepartementet, 2011). Ledelse er et mangefasettert begrep som er gitt ulike definisjoner. Det er imidlertid enighet om at kjernen i lederskap er å benytte verdier og visjoner for å sette standarder for atferd og klargjøre ønskede fremtidsstilstander (Kirkhaug, 2013). Dette kapitlet er basert i en studie som retter søkelyset mot avdelingsledere i norske sykehjem. Avdelingslederne befinner seg i en mellomlederposisjon, deres funksjon er plassert mellom overordnede ledere og førstelinjemedarbeidere. Mellomlederne i kommunale sykehjem (omtales videre som ledere) møter mange og ofte motstridende forventninger i sin lederrolle, fordi oppgavene er omfattende og krevende innenfor både drift, personal og fag.

Dette kapitlets hensikt er å belyse utfordringer som ledere i kommunale sykehjem møter når de utøver lederskap, og spesielt hvordan lederne benytter sitt handlingsrom for å imøtekomme disse utfordringene. Studien bygger på en kvalitativ intervjuundersøkelse av sju mellomledere i 
fem sykehjem i tre mellomstore norske kommuner. Det kunnskapsmessige siktemålet er å styrke kunnskapen om hvordan ledere kan benytte sitt handlingsrom for å håndtere utfordringer i utøvelse av lederskap i kommunale sykehjem. Ledernes handlingsrom består av ytre føringer og pålegg i form av for eksempel lover, politiske beslutninger og utdanning samt av indre føringer som kan knyttes til holdninger, kompetansesammensetning samt formell og uformell organisering (Schönfelder, Andersen \& Kane, 2018; Selznick 1984). Økt forståelse for hvordan ledere kan benytte sitt handlingsrom i kommunale sykehjem er viktig, fordi forskning viser at kompleksiteten i arbeidsoppgaver utfordrer ledernes mulighet for å tilrette slik at forsvarlige helse- og omsorgstjenester kan ivaretas (Tingvoll, Sæterstrand \& McClusky, 2016; Helse- og omsorgstjenesteloven, 2011).

Ledelse i kommunale sykehjem er et område med behov for oppmerksomhet også fordi kravene til ledelse i kommunale sykehjem er endret i takt med sykehjemmenes funksjon gjennom de femti årene sykehjemmene har eksistert. Forskriftene har i liten grad vært endret siden 1980, til tross for omfattende reformer og endringer i den kommunale helseog omsorgstjenesten. Opprinnelig hadde sykehjemmene hovedsakelig ansvar for pleieoppgaver, men arbeids- og ansvarsområdene er etter hvert blitt mer omfattende (Abelsen, Gaski, Nødland \& Stephansen, 2014; Bruvik, Drageset \& Abrahamsen, 2017). Samhandlingsreformen førte til at utskrivningsklare sykehuspasienter med komplekse sykdomsbilder nå blir overført til sykehjem. Følgelig er sykehjempasienter i økende grad under medisinsk behandling og rehabilitering (Helse- og omsorgsdepartementet, 2009). De vanligste hoveddiagnosene for sykehjempasienter er aldersdemens, hjerneslag, kronisk hjerte- og lungesykdom, lårhalsbrudd og slitasjegikt (Helbostad, 2005; Bruvik et al., 2017). Sykere pasienter med sammensatte lidelser skaper behov for økt kompetanse og flere ansatte i forbindelse med medisinsk behandling og rehabilitering (Ytrehus \& Nuland, 2007; Tingvoll, Sæterstrand \& Fredriksen, 2010; Tingvold \& Magnussen, 2018). Den politiske debatten preges av ulike syn på hvilke funksjoner sykehjem skal ivareta i helse- og omsorgstjenesten, og det diskuteres hvilket behandlingsnivå sykehjemmene skal ivareta (Tingvold \& Mangnussen, 2018; Høie, 2005). Velfungerende sykehjem er imidlertid en 
nøkkelfaktor dersom helsevesenet skal kunne ivareta en stadig økende eldre befolknings behov for medisinsk behandling, pleie og rehabilitering. Konteksten for ledelse i sykehjem er slik blitt stadig mer utfordrende når myndighetenes og profesjonenes krav skal ivaretas.

\section{Ledelsesforskning i helsefeltet}

Ledelse handler om administrativ og faglig tilrettelegging for gode tjenester og opplevd kvalitet, blant annet fordi 70-9o prosent av forbedringsområdene i helsetjenesten er av organisatorisk karakter, mens 10-30 prosent av forbedringsområdene knyttes til faglige utfordringer (Arntzen, 2014). Sørensen (2006) fremhever at sykepleieres ledelse vil variere ut fra om sykepleieleder går inn i rollen som kliniker, som administrator eller som hybridleder. Hvis lederen går inn i sin rolle som kliniker, kan lederrollen preges av manglende samspill mellom fag og ledelse fordi oppmerksomheten rettes mot klinisk praksis. En leder som forvalter sin lederrolle som en administrator, bidrar til at samspillet mellom ledelse og fag blir skadelidende. Hybrid ledelse, det vil si at lederen pendler mellom fag og andre ledelsesfunksjoner, styrker samspillet mellom ledelse og fag. Den hybride ledelsesformen er også aktualisert av reformer som har bidratt til sterkere oppmerksomhet på økonomi (Christensen \& Lægreid, 2011; Berg, 2015). Ledelse i helse omhandler også tilrettelegging for kompetansevikling. Kompetanse kan forstås som de samlede kunnskapene, ferdighetene, evnene og holdningene en person må ha hvis vedkommende skal kunne utføre bestemte oppgaver i samsvar med nærmere definerte krav og mål (Lai, 2013). Kunnskap kan ha både en eksplisitt og en taus dimensjon. Eksplisitt kunnskap kan verbaliseres og videreformidles og blir vanligvis systematisert gjennom strukturer, rutiner og prosedyrer for å styre for eksempel tjenesteutøvelse (Jacobsen \& Thorsvik, 2019). Taus kunnskap lar seg vanskelig verbalisere, da kunnskapen ofte er internalisert og føres videre gjennom observasjon og handling (Polanyi, 2009). Kunnskap og holdninger henger sammen, og holdninger utvikles når verdier formidles og internaliseres (Martinussen, 1991).

Faglig ledelse og forskning, oppdatert kunnskap samt brukermedvirkning er sentrale elementer for kvaliteten i helsetjenesten (Nortvedt, 
Jamtvedt, Graverholt, Nordheim \& Reinar, 2012). Det fremheves at sykepleiernes kunnskapsbase kontinuerlig må fornyes (Nortvedt \& Grønseth, 2016), samt at økte effektivitetskrav påvirker kvaliteten i sykepleie negativt (Kristoffersen \& Friberg, 2016). Det fremkommer for eksempel at sykepleiere i økende grad utfører oppgaver som matlaging, klesvask og rengjøring, oppgaver som andre ansatte utøvet tidligere, noe som utfordrer lederes handlingsrom for å tilrettelegge for forsvarlige og omsorgsfulle tjenester (Pedersen \& Tingvoll, 2014). Fagledelse innebærer forvaltning av kompetanse.

Det har vært spesielt utfordrende å få aksept for generell ledelse i helsevesenet (Berg, Byrkjeflot \& Kvåle, 2010). Berg (2015) viser imidlertid hvordan ledelse i helsevesenet har beveget seg fra å være profesjonsbasert til å bli mer hybrid, der det søkes å kombinere generell og sykepleiefaglig ledelse. Forskning tyder på en positiv sammenheng mellom relasjonsledelse og pasientenes situasjon, eksemplisifisert ved færre infeksjoner og lavere dødelighet (Wong \& Cummings, 2007; Wong, Cummings \& Ducharme, 2013). Økt forståelse for hvordan ledere kan benytte sitt handlingsrom i en presset arbeidshverdag er dermed viktig. Styrket kvalitet gjennom relasjonsledelse kan ha sammenheng med at sykepleieledere som inkluderer ansatte, motiverer til økt ytelse blant sykepleierne (Germain \& Cummings, 2010). Følgelig er støttende ledelse avgjørende for å styrke omsorgskvaliteten (André, Sjøvold, Rannestad \& Ringdal, 2014).

\section{Teoretisk referanseramme}

Ifølge Røvik (2007) er byråkratiet fremdeles den dominerende organisasjonsformen i ulike virksomheter i Norge. Sykehjemmet kan betraktes som et profesjonelt byråkrati kjennetegnet av at ansatte med sin profesjonsbakgrunn er tildelt en viss beslutningsmyndighet og handlefrihet. Organisasjonsstrukturen definerer hvordan arbeidsoppgaver i organisasjonen skal fordeles, grupperes og koordineres (Jacobsen \& Thorsvik, 2019). Sykepleieoppgaver er koordinert og standardisert, og profesjonelle utøvere representerer en felles fagkunnskap som er med på å kvalitetssikre arbeidet. Ledere i sykehjem forvalter makt, og makt betegner ubalanse i relasjoner mellom ulike aktører (Engelstad, 2005). Ifølge Weber 
(1971) kan makt forstås som det å få sin vilje igjennom, til tross for motstand. Denne forståelsen av makt ligger til grunn for diskusjonene i dette kapitlet, fordi det relasjonelle aspektet ved maktutøvelse er sentralt, her belyst hovedsakelig gjennom relasjonene leder-ansatt og ansatt-ansatt. Goffmans (1992) begreper om situasjonsdefinisjon og selvpresentasjon er også sentrale fenomener i forståelsen av maktutøvelse og samhandling. Selvpresentasjon viser til at en aktør søker å kontrollere den måten andre behandler ham på. Gjennom selvpresentasjon søker aktøren å etablere sin definisjon av en situasjon og samtidig påvirke andre til å godta definisjonen. Aktøren styrer med andre ord formidlingen av seg selv for å lede andre til frivillig å handle slik han ønsker. Hvem som har definisjonsmakt i ulike saker, vil kunne ha betydning for det handlingsrommet en leder erfarer å ha i sykehjemmet.

Utøvelse av makt i formelle lederposisjoner har både et oppgave- og relasjonsfokus (Hemphil \& Coons, 1957). Kirkhaug (2013) omtaler relasjonsfokus som at ledere ofte legger vekt på ansattes medvirkning i beslutningsprosesser, jobbtilfredshet, støtte i jobbutførelsen og velferd. Oppgavefokus innebærer at lederen er mest opptatt av måloppnåelse, kontroll og effektivitet, og i senere forskning er de to dimensjonene ofte betraktet som motsetninger, men dimensjonene opptrer ofte sammen (Kirkhaug, 2013). Sørensen (2006) omtaler også ulike dimensjoner ved lederskap og gjør rede for hybrid lederskap i helsesektoren. Sørensen (2006) poengterer at samspillet mellom driftsmessige og sykepleiefaglige oppgaver bidrar til at både sykepleie- og ledelsesfaglige identiteter aktiviseres i lederrollen, og viljen til å ivareta de ulike identitetene løftes slik fram i hybrid lederskap.

Administrasjon og ledelse kan betraktes som to separate funksjoner (Kirkhaug, 2013; Yukl, 2019). Administrasjon omhandler blant annet det å kunne takle kompleksitet, utføre rutinemessige oppgaver, implementere planer og etterse at regler og rutiner blir etterfulgt (Kaufmann \& Kaufmann, 2015; Kotter, 2012; Martinsen, 2012; Strand, 2007), og sykepleiere i lederstillinger ivaretar et mangfold av slike administrative oppgaver. Ledelse kan deles inn i flere funksjoner. I dette kapitlet benyttes begrepene relasjonsledelse og sykepleiefaglig ledelse for å belyse hvordan lederne utøver lederskap for å imøtekomme ulike utfordringer i kommunale sykehjem. Relasjonsledelse betegner en leder som viser omsorg og 
respekt, samtidig som vedkommende er orientert mot det å lede gjennom relasjonen for å nå organisasjonens mål (Birkinshaw, 2014; Strand, 2007). Sykepleiefaglig ledelse er omfattende og innbefatter blant annet tverrprofesjonelt samarbeid, ansvar for å vurdere pasienters behov for sykepleie samt sykepleietiltak (Kristoffersen, 2016b). Samtidig har lederne ansvar for faglig oppdatering og dokumentasjon som sikrer det faglige innholdet i tjenesteutøvelsen (Kristoffersen, 2016a; Pfeiffer, 2002; Orvik, 2015; Tingvoll, Pedersen \& Nymo, 2018). Hvordan en leder benytter sitt handlingsrom, vil kunne få betydning for hvordan vedkommende beveger seg mellom administrative oppgaver og sykepleiefaglig og relasjonell ledelse for å imøtekomme utfordringer i sin arbeidshverdag.

Handlingsrommet for ledelse i kommunale sykehjem kan oppleves forskjellig av ulike ledere, og i teorien skilles det ofte mellom et formelt og et subjektivt definert handlingsrom (Hambrick \& Mason, 1984; Hambrick \& Finkelstein, 1987; Stewart, 1989; Finkelstein \& Hambrick, 1996). Det formelle handlingsrommet etableres av de forventningene som rettes mot ansattes oppgaveløsning (jobbkrav) innenfor et hierarki der lover, makt, ansvar, ressurser, regler og normer er sentrale førende elementer. Den organisasjonsmessige styringen er bygget inn i krav og prosedyrer i organisasjonen, og organisasjonsstrukturen kan oppleves som mer eller mindre rigid. Befinner en sykepleieleder seg innenfor en rigid organisasjonsstruktur, kan vedkommende erfare lite frihet og begrenset handlingsrom for å imøtekomme utfordringer i sin utøvelse av ledelse. Ledere kan imidlertid tolke og forstå både forventninger og strukturelle føringer ulikt (Strand, 2007), noe som gir den enkelte mulighet til å forme og bruke sitt subjektive handlingsrom slik at det fremkommer flere løsningsalternativer når utfordringer skal imøtekommes.

\section{Metodisk tilnærming}

I studien er det benyttet en kvalitativ tilnærming i form av semistrukturerte intervjuer, fordi det er informantenes egne erfaringer som er i søkelyset (Kvale, 1996). Vi søkte målrettet etter informanter som var i en lederposisjon i kommunale sykehjem, og som kunne gi oss innblikk i ledelsesutfordringer og håndtering av disse. Vi benyttet med andre ord et 
hensiktsmessig utvalg (Bryman, 2015). Den første lederen ble ringt av en av forskerne høsten 2019, og det ble redegjort muntlig for undersøkelsen. Lederen ga sitt samtykke til at avdelingsleder ved sykehjemmet kunne delta, under forutsetning av at avdelingslederen selv ønsket det. Samme forsker tok så direkte kontakt med ledere av fire andre sykehjem, som så videreformidlet informasjon om vår studie til sine avdelingsledere. Vi fikk tilgang til sju informanter som alle ga sitt informerte samtykke til å delta i undersøkelsen. Informantene ble opplyst om at de kunne trekke seg fra undersøkelsen når som helst, hvis de ønsket det. Ingen informanter trakk seg. Vi valgte å gjøre de initierende henvendelsene til lederne av hvert enkelt sykehjem, fordi det var nødvendig at de godkjente en undersøkelse som involverte deres ansatte. Det at lederne til våre informanter godkjente deltakelse, kunne kanskje oppleves som en forpliktelse for hver enkelt avdelingsleder, og det er uvisst om dette kan ha påvirket våre data. Sykehjemmene var lokalisert i tre kommuner. Intervjuene ble gjennomført på informantenes arbeidssted og varte i en til en og en halv time, og det var to intervjuere til stede. Det ble gjort lydopptak av samtalene som senere ble transkribert og analysert. Personidentifiserbare opplysninger ble anonymisert $\mathrm{i}$ transkripsjonen, og våre data er lagret $\mathrm{i}$ låst skap.

Vi valgte å benytte semistrukturerte intervjuer fordi metoden gir mulighet for å gjennomføre samtaler etter en viss struktur, samtidig som informantene formidler sine erfaringer med egne ord og mest mulig fritt innenfor det temaet som tas opp. I intervjuene ble oppmerksomheten rettet mot ledernes erfaringer med utfordringer knyttet til fagledelse, administrasjon og andre lederoppgaver i forbindelse med daglig drift og personell. Semistrukturerte intervjuer var en egnet metode også fordi samtaleformen ga oss rom for å utdype og følge opp utsagn som beriket dataene (Denzin \& Lincoln, 2017; Kvale \& Brinckman, 2015). Informantenes innspill introduserte sammenhenger og fenomener som vi som forskere med et utenforperspektiv ikke var bevisst eller hadde forstått. Det at vi var to forskere til stede, opplevde vi som en styrke med hensyn til oppfølgingsspørsmål, fordi vi la merke til ulike utsagn og slik kunne få et rikt datatilfang. Det er mulig at to forskere kunne virke litt overveldende for den enkelte informanten, men vi la vekt på å skape en rolig og avslappet atmosfære, og informantene var aktive og delte villig av sine erfaringer. 
Informantene ga tydelig uttrykk for at intervjusituasjonen hadde vært en god opplevelse, og alle ga oss tillatelse til å komme tilbake hvis vi hadde behov for ytterligere informasjon.

Data ble fortolket og analysert ved hjelp av en fenomenologisk-hermeneutisk tilnærming med søkelys på meningsfortetting og utvikling av meningsenheter (Kvale, 1996). Analyse- og fortolkningsprosessen innebar en stadig bevegelse mellom mulige subtemaer og temaer. Først ble de transkriberte intervjuene gjennomlest, og utsagn som fortalte om ledelsesutfordringer og forsøk på å overkomme utfordringene, ble markert i margen. I andregangslesningen ble det markert i materialet, og det ble formulert mulige subtemaer. Videre ble sitater for de mulige subtemaene som framkom, sammenstilt i oppsummeringer, og det ble utviklet mulige temaer. For å analysere fram felles subtemaer og temaer ble materialet fra oppsummeringene sett på tvers. Intervjuene ble analysert en gang til etter at temaene var utviklet, for å ivareta undersøkelsens validitet best mulig.

\section{Empiriske funn}

Gjennom dataanalysen fremkom tre utfordringer som alle fører til økt og tidkrevende administrasjon:

1. midlertidige sykehjemsplasser blir permanente, noe som krever sterkt faglig fokus

2. søk etter vikarer, noe som er en ressurskrevende aktivitet

3. ulike former for kunnskap har forskjellig status i sykehjemmene, noe som også skaper behov for holdningsarbeid blant alle ansatte i avdelingene.

Dataanalysen viser at lederne søker å imøtekomme utfordringene om faglig fokus ved å sette sammen faglige team og ved å samtale med spesialisthelsetjenesten. For å imøtekomme utfordringer knyttet til vikarbehov og vikarsøk utvikler lederne vikarbaser, delegerer vikarsøk til en annen ansatt, utformer lister der vikarer selv kan velge vakter, eller ringer til personer i nærmiljøet for å få tak i vikarer. Behovet for holdningsendringer ble søkt løst gjennom å rose vikarenes arbeid i påhør av andre, gjennom 
igangsetting av tiltak som innebar kompetansedeling, og gjennom styrking av veiledningskompetansen til fagansatte og kompetansen generelt for vikarer. I det følgende benyttes parentes og tre prikker for å vise at ord er fjernet fra dataene for å skape sammenheng i informatenes utsagn.

\section{Presentasjon av data}

\section{Utfordringer knyttet til ledelse i kommunale sykehjem}

Studien viser at pasienter som kommer fra hjemmesykepleien for avlastning i en periode, blir værende i sykehjemmet, og dette skaper ulike utfordringer. En leder sier det slik: «De som bor hjemme, og som blir prioritert inn i sykehjem, de kommer ikke videre, ikke ut igjen.» En annen leder gir uttrykk for at «de som er typiske hjemmesykepleiepasienter, vi får dem ikke ut. De bare fortsetter å være her». En tredje leder forteller at pasienter som kommer fra spesialisthelsetjenesten, og som skal ha et midlertidig opphold i sykehjemmet, blir værende fordi de er for syke til å være hjemme. En fjerde leder beskriver situasjonen slik: «Det som skulle være korttidsplasser, blir til langtidsplasser.» Lederne opplever endringene i bruk av korttidsplasser som utfordrende, og de forklarer at endringene har sammenheng med manglende tilbud i hjemmesykepleien, og med at hjemmetjenesten mangler tilstrekkelig kvalifisert personell. Ledernes utsagn kan forstås som at når pasientstrømmen mellom spesialisthelsetjenesten, sykehjemmene og hjemmetjenesten dempes eller stopper opp, preges handlingsrommet for ledelse av økt administrativt press, og av en fagledelse som rettes spesielt mot sammensetningen av kompetente team for å ivareta pasienter med sammensatte og komplekse behov.

I dataanalysen fremkommer det også utfordringer knyttet til at kompetansetilfanget i sykehjemmene påvirkes av sykefravær og permisjoner. De forteller om tidkrevende arbeid og vansker med å skaffe kvalifiserte vikarer. En leder sier det slik: «Fordi det går så mye tid! Tid som kunne vært brukt på andre ting, som for eksempel oppfølging av sykemeldte.» Også andre ledere forteller at de tidligere brukte uforholdsmessig mye tid på vikarsøk, men at de etter hvert fant løsninger som dempet tidspresset. 
Utsagnene kan forstås som at handlingsrommet for de fleste lederne preges av økt administrasjon på grunn av mangelfull rekruttering av kvalifiserte vikarer.

Data viser videre at lederne møter utfordringer når de søker å integrere vikarer i arbeidsfellesskapet, fordi fagansatte ofte undervurderer betydningen av vikarenes kunnskap i tjenesteutøvelsen. En leder forteller:

Vi har en ufaglært voksen dame som jobber her. Som har jobbet med å håndtere folk i hele sitt liv i restaurantbransjen. Der skal man behandle folk med verdighet $(. .$.$) de der, de der er fantastisk å håndtere disse beboerne. De har så mye$ inni seg som rett og slett er erfaringskunnskap som hun ikke har lest i en bok eller lært, men hun har gjort dette i livet sitt og håndterer pasientene våre på en fantastisk måte.

En annen leder sier det slik: «Og du trenger ikke nødvendigvis sykepleieutdanning for å ha den kunnskapen, hvordan man håndterer og behandler mennesker (...).» Samme leder forteller en illustrerende historie:

Vi hadde en her ute som er dement, som nektet å gå noe sted. Vi har en meget dyktig hjelpepleier som har jobbet her i tretti år, som sto her med pasienten, men som ikke fikk pasienten av flekken. Så prøver jeg meg, med en autoritær tilnærming i forhold til å få pasienten til å rikke seg. Men så kommer denne pleieassistenten som står og kikker om det er noen ledig vakt. Dette er en liten mann, han kommer inn hovedinngangen, ser situasjonen og strekker hånden bort til henne og sier: «Kom, nå går vi.» Så reiser hun seg opp, og så går de.

Lederen fortsetter: «Her kommer jeg med min erfaring, tyve år som sykepleier og jobbet med dette i tyve år. Dette kan jeg! Ikke kom her! Og så kommer han og overtar hele greien.» Lederen lurer på hvorfor dette skjer, og sier:

Men han kan ikke sette finger på det, hvorfor han får det til. Men han klarer det fordi han er som han er. Han er ingen trussel, om det er det? Jeg har ikke peiling! Jeg sitter her med videreutdanning ... og så klarer han det og ikke jeg! 
Det fremkommer videre at mange fagansatte har en tendens til å nedvurdere vikarenes kunnskap. En tredje leder beskriver hvordan ansatte kan gi uttrykk for sin mening, og vedkommende sier: «Kom ikke her med dette, du. Vi har vurdert at ...» Lederen fortsetter: «Det kan være nok til å ta knekken på stolthet til å bidra.» En annen leder sier: «Vikarer må ikke behandles som ubetydelige personer, fordi de har stor betydning her. De jobber veldig mye.» En fjerde leder forteller: «Assistentene har en tendens til å undervurdere seg selv», og en sier det slik: 'Det jeg sier, er ikke så mye verdt, for jeg har ingen utdanning'.» Vikarene oppfordres av lederne til å ta utdanning som helsearbeidere. Utsagnene kan forstås som at både fagansatte og vikarene selv i liten grad anerkjenner vikarenes erfaringskompetanse, noe som har negativ innflytelse på relasjonene mellom ansatte og på realiseringen av vikarers erfaringskunnskap i sykehjemmene, og det er behov for holdningsarbeid.

\section{Utfordringene imøtekommes forskjellig}

Flere informanter forteller at for å imøtekomme utfordringer som oppstår i tilknytning til omdefinerng av midlertidige plasser til permanente plasser i sykehjemmene, bruker de tid på å ha kontakt med ansatte i spesialisthelsetjenesten om reinnleggelser når pasientenes situasjon ikke endrer seg til det bedre. En leder sier det slik: «Jeg ringer og bruker mye tid på å få fatt i riktig person når jeg har spørsmål om ulike pasienter.» Lederne sier at samtaler med spesialisthelsetjenesten er nødvendig fordi sykehjemmenes kompetansesammensetning utfordres når flere pasienter med komplekse og sammensatte lidelser skal ivaretas samtidig over tid. Lederne forteller videre at de søker å løse utfordringer knyttet til pasienter med komplekse og sammensatte lidelser ved å sette sammen arbeidsteam med nødvendig kompetanse og erfaring som best mulig kan ivareta pasientenes pleie- og omsorgsbehov. Ledernes uttalelser kan forstås som at deres handlingsrom preges av økt administrasjon og utfordrende fagledelse, fordi den forventede dynamikken i helsetjenesten stopper opp i sykehjemmene. Lederne søker å imøtekomme utfordringene gjennom teamsammensetning i sykehjemmet samtidig som de prøver å ansvarliggjøre spesialisthelsetjenesten. 
Når det gjelder vikarsøk, har lederne valgt ulike løsninger, men mange ringer personer i nærmiljøet. En leder uttrykker det slik: «Jeg ringer og ringer i håp om få fatt i kvalifisert personell, bruker masse tid.» En av lederne har gitt oppgaven til en ansatt som lederen samarbeider tett med, og slik har lederen frigjort tid til andre oppgaver. Lederen sier: «Det har gått år og dag siden jeg ringte en vikar selv. Jeg har outsourcet en uhyre dyktig hjelpepleier, så jeg har mer kontakt med pårørende, mye, spesielt i vanskelige saker.» Lederen fortsetter: «Vi hadde en hjelpepleier med dårlige skuldre. Vi har tilrettelagt en del av hennes stilling til (...) Lotus-ressursstyringsprogrammet vi har, der vi leier inn og ut vikarer.» En annen leder løser utfordringene ved å ha ringelister over vikarer. Lederen sier:

Jeg sørger for å ha en enorm vikarpool å ta av. Ja. Jeg har 15 ringevikarer på listen, og er det plutselig noen som faller ut, som forteller at denne vikarlivsstilen ikke passer for dem, at de har fått fast jobb og gjør noe annet, så finner jeg en ny. Vi er helt nødt, også må vi tenke utenfor den boksen, for vi får ikke alltid norsk personell.

En tredje leder forteller at de har anskaffet et elektronisk system for vikarer der «(...) vi legger ut alle vaktene så de kan gå inn og shoppe på de». En fjerde informant illustrerer utfordringene: «Jeg møtte veggen og hadde veldig mye arbeid i forhold til administrasjon. Det er tøft å snakke om.»

Utfordringer knyttet til liten anerkjennelse av vikarenes erfaringskompetanse møtes også forskjellig av ulike ledere. En leder påpeker: «Det går på å jobbe med holdninger hele tiden.» En av lederne forteller at hun i arbeidet med å påvirke ansattes holdninger fremsnakker og roser vikarene for det de bidrar med, som eksempelvis: «Det dere sier nå, er så viktig. Den journalen er fantastisk godt skrevet!» En leder forteller at holdningsarbeidet innebærer å legge til rette for økt deling av erfaringskunnskap blant ansatte gjennom internundervisning. Andre ledere motiverer ansatte til å øke sin veiledningskompetanse gjennom kurs. En av lederne utdyper: «Vi har hatt medarbeidersamtaler med alle sykepleierne nå og oppfordrer dem til å ta kurs for å gi veiledning til sine medarbeidere». Sykepleierne oppfordres også til å gi veiledning til pårørende og 
studenter. I tillegg oppfordres vikarer til å øke sin kompetanse for å bli helsefagarbeidere. Andre ledere er opptatt av utvikling av gode rutiner for opplæring av nyansatte og vikarer for å endre holdninger og for å få til best mulig kvalitet og kontinuitet i omsorgsutøvelsen. Lederne gir imidlertid klart uttrykk for at vikarenes erfaringskunnskap er et viktig bidrag til kunnskapsbasen i sykehjemmene.

\section{Diskusjon}

\section{Komplekse lederutfordringer}

I det følgende diskuteres hvordan lederne i kommunale sykehjem benytter sitt handlingsrom for ledelse når de søker å imøtekomme utfordringene de står overfor. Diskusjonen tar utgangspunkt i hvordan lederne benytter sitt handlingsrom når de søker å imøtekomme utfordringer knyttet til begrenset flyt i pasientstrømmen mellom spesialisthelsetjenesten, sykehjem og hjemmesykepleien. Studien viser at permanent økning i antall pasienter med komplekse og sammensatte pleie- og omsorgsbehov fører til flere administrative oppgaver, økt arbeids- og ansvarspress og derigjennom økt oppmerksomhet på sykepleiefaglig ledelse. Det fremkommer videre at vikarbehov og vikarsøk også bidrar til å øke ledernes administrative aktivitet, og oppgavene oppleves som tidkrevende fordi det ofte er vanskelig å få fatt i kvalifiserte vikarer. Når så vikarer skal delta $\mathrm{i}$ arbeidshverdagen i sykehjemmene, opplever de at deres erfaringskompetanse blir lite verdsatt av fagansatte. Hos vikarene ser dette ut til å skape utrygghet knyttet til både egen rolle og bruk av erfaringskompetansen i sykehjemmene. Studien viser at det er behov for å arbeide med relasjoner og holdningsendring hvis vikarenes kompetansepotensial skal kunne realiseres i sykehjemmene. Ledernes handlingsrom fremstår som preget av mange og komplekse utfordringer som skal imøtekommes.

\section{Ledelse og bruk av handlingsrom}

Studien tyder på at lederne erfarer begrenset formelt handlingsrom når den forventede dynamikken i helsetjenesten stopper opp, og når handlingsrommet preges av økt administrativt press, samtidig som begrenset 
kompetanse for å ivareta pasienter med komplekse og sammensatte lidelser blir tydelig. Lederne søker å dempe kompetanseutfordringene ved å ansvarliggjøre spesialisthelsetjenesten, og de ber om faglig støtte og reinnleggelser. Stort sett ser imidlertid denne løsningen ut til å fungere som brannslukking i øyeblikket, for når disse pasientene kommer tilbake, blir de fremdeles værende i sykehjemmet. Pasientene blir værende fordi den forventede dynamikken i pasientflyten mellom sykehjem og hjemmesykepleie er svekket, da hjemmesykepleien også mangler faglig kompetanse for å ivareta pasienter med sammensatte og komplekse lidelser (Tingvoll, Sæterstrand \& Fredriksen, 2010). Dette fører til et fortsatt behov for omfattende sykepleiefaglig kompetanse i sykehjemmene når pasientenes pleiebehov skal ivaretas. Sykehjemmenes mellomposisjon i systemet for pasientflyt bidrar trolig til at utfordringene knyttet til sykepleiefaglig ledelse kan bli et vedvarende kjennetegn i ledernes formelle handlingsrom. Dersom det formelle handlingsrommet skal endres, må det trolig skje endringer i spesialisthelsetjenestens rutiner for utskrivning av pasienter og i hjemmesykepleiens kompetansetilfang.

Studien tyder på at ledernes søkelys på sykepleiefaglig ledelse og administrasjon for å ivareta pasienter og sikre daglig drift er tid- og oppmerksomhetskrevende og vedvarer over tid. Denne situasjonen kan snevre inn ledernes handlingsrom for å ivareta andre lederfunksjoner, samtidig som situasjonen kan skape et handlingsrom preget av krysspress. I følge Schiefloe (2011) innebærer krysspress at det rettes motstridende og ofte uforenelige forventninger til lederrollen (Schiefloe, 2011). Et handlingsrom preget av krysspress kan over tid være en påkjenning for den enkelte lederen, noe som kommer tydelig til uttrykk i vår empiri når ledere forteller om høy arbeidsbelastning og motstridende krav som rettes mot lederrollen. Kirkhaug (2013) fremhever at et handlingsrom for ledelse som preges av begrensninger, kan redusere mulighetene for å ivareta det relasjonelle aspektet ved ledelse. Dette kommer også til uttrykk i vår empiri når ledere forteller om begrenset formelt handlingsrom for å følge opp sykemeldte og legge til rette for ansatte med behov for avlastning fra spesielt belastende arbeidsoppgaver. Et formelt handlingsrom for utøvelse av lederskap som begrenser mulighetene for å ivareta det relasjonelle aspektet, er betenkelig, fordi relasjonsledelse har stor betydning 
for positive pasientresultater (Wong et al., 2013; Germain \& Cummings, 2010; Cummings et al., 2010; André et al., 2014).

Studien viser at flere ledere ser mulighet for å benytte sitt subjektive handlingsrom (Strand, 2007) for å imøtekomme utfordringer knyttet til vikarmangel, vikarsøk og behov for holdningsarbeid for å gi rom for vikarers erfaringskompetanse. En leder benytter for eksempel sitt subjektive handlingsrom til å delegere vikarsøk til en ansatt som har behov for avlastning fra pleieoppgaver på grunn av helseutfordringer. Slik ivaretar lederen den ansattes behov for endring i arbeidssituasjonen. To andre ledere utvikler henholdsvis et elektronisk system der vikarer kan velge vakter, og en «vikarpool» som sikrer vikartilfang i den grad det er mulig. Lederne er oppmerksomme på og benytter slik sitt subjektive handlingsrom og frigjør seg fra tidkrevende administrasjon, og de skaper rom for å rette oppmerksomhet mot andre lederfunksjoner. Ledernes evne (Strand, 2007) til å rette oppmerksomheten mot et subjektivt handlingsrom kan slik bidra til at handlingsrommet for ledelse utvides, blant annet fordi lederne gir uttrykk for at løsningene fungerer over tid.

Studien tyder på at flere ledere også benytter sitt subjektive handlingsrom når de søker å påvirke holdninger og en negativ dynamikk i relasjonene mellom ansatte og vikarer. Relasjonsutfordringene fremkommer når vikarenes erfaringskompetanse skal benyttes i tjenesteutøvelsen. Lederne ser muligheter og setter i gang ulike kompetansetiltak som tar sikte på å endre holdninger slik at vikarenes erfaringskompetanse kan realiseres. Gjennomføring av disse tiltakene kan imidlertid være krevende fordi holdninger har flere komponenter. En kognitiv komponent forteller om den virkelighetsforståelsen holdningene bygger på, mens en affektiv komponent omhandler følelser og standpunkter. En atferdsmessig komponent forteller noe om forholdet mellom holdning og handling (Martinussen, 1991). Holdningers mange dimensjoner kan bidra til at ledernes forsøk på å endre holdninger kan bringe fram både positive og negative reaksjoner hos ansatte, og over tid vil ledernes mulighet for å benytte det subjektive handlingsrommet til holdningsarbeid trolig avhenge av støtte i fagmiljøet. Dette fordi profesjonsutøvere kan oppleve omfattende inngrep fra andre i organisasjonen som utfordrende, da de krever en viss selvstendighet i sin tjenesteutøvelse (Jacobsen \& Thorsvik, 2019). Oppslutning i 
fagmiljøet kan ivaretas gjennom relasjonsledelse der man retter søkelyset på sosial samhandling og støtte i arbeidshverdagen, fordi det motiverer til å slutte opp om ledernes tiltak (Oldham \& Hackman, 2010; Morgeson \& Humphrey, 2006; Humphrey, Nahrgang \& Morgeson, 2007). Valg av tiltak kan på sikt myndiggjøre den enkelte ansatte, og tiltakene kan bidra til at innhold i arbeidsoppgaver og roller avklares etter hvert som ansattes kompetansebidrag tydeliggjøres gjennom erfaringsdeling, veiledning og kompetanseheving. Tydeligere roller samt ansvars- og oppgavefordeling kan endre den negative dynamikken som preger samhandlingen mellom fagansatte og vikarer. Annen forskning viser at det er klare sammenhenger mellom uklare roller, frustrasjon og konfliktnivå i et arbeidsmiljø (Valentine, Godkin \& Varca, 2010; Lai, 2013). Studien tyder på at når lederne benytter sitt subjektive handlingsrom, kan det være mulig å få til en balansert pendling mellom fag, administrasjon og andre ledelsesfaglige identiteter (Sørensen, 2006). Hvordan ledere definerer sitt subjektive handlingsrom, viser seg å være viktig for de valgene og handlingene ledere foretar (Strand, 2007; Espedal, 2009; Espedal, Kvitastein \& Grønhaug, 2012), noe som også fremkommer i vår studie.

\section{Konklusjon}

I denne studien har vi diskutert utfordringer knyttet til utøvelse av ledelse i kommunale sykehjem, samt hvordan lederne benytter sitt handlingsrom for å imøtekomme utfordringene. Sykehjemmenes rolle som mellomstasjon for utskrivningsklare pasienter fra sykehus samt deres rolle som avlastningsenhet for pasienter i hjemmesykepleien skaper utfordringer i form av økt administrasjon og omfattende sykepleiefaglig ledelse. Ledernes kontakt med spesialisthelsetjenesten for å imøtekomme utfordringer knyttet til manglende pasientflyt kan tyde på et uavklart ansvarsforhold mellom spesialisthelsetjeneste og kommunal helsetjeneste. Dette får omfattende innflytelse på ledernes mulighet for å ivareta blant annet relasjonsledelse. Denne lederfunksjonen kan være spesielt viktig fordi sykehjemmene sliter med å få kvalifisert personell samtidig som arbeidsoppgavene blir stadig mer komplekse. Handlingsrommet for ledelse preges også av utfordringer knyttet til tidkrevende vikarsøk, samtidig som 
det er utfordrende å få anerkjent vikarenes erfaringskompetanse når de blir en del av sykehjemmenes stab. Lederne søker derfor å arbeide kontinuerlig med å påvirke holdninger knyttet til vikarenes erfaringskunnskap for å realisere denne kunnskapens potensial. Studien viser at ulike ledere benytter sine handlingsrom forskjellig når de søker å imøtekomme utfordringene. Noen ledere ser ut til å imøtekomme utfordringene gjennom ulike former for brannslukking, noe som trolig skaper varige begrensninger i handlingsrommet for utøvelse av de ulike funksjonene som ledelse i kommunalt sykehjem innebærer. Studien tyder på at ledere som evner å benytte sitt subjektive handlingsrom, ser og finner løsninger som frigjør tid fra administrativ ledelse, og de får til en pendling mellom administrasjon og andre ledelsesfunksjoner. Det at bruk av det subjektive handlingsrommet kan gi muligheter for å utvikle varige løsninger som ikke begrenser utøvelse av ledelse til administrasjon og fagledelse under press, er viktig og reiser nye spørsmål. Hva gjør at noen ledere ser - og benytter - sitt subjektive handlingsrom med det resultatet at de kan få til en pendling mellom ulike lederfunskjoner som ivaretar både ansatte, pasienter og daglig drift? Personlige egenskaper er blitt holdt frem som en mulig forklaring (Espedal \& Kvitastein, 2012), men personforklaringer er ikke tilstrekkelig. Ved å benytte begrepet subjektivt handlingsrom i videre forskning kan eventuelle nye strukturelle og relasjonelle fenomener som har betydning for lederfokus og endringspotensial, belyses. Kunnskap om lederes bruk av det subjektive handlingsrommet kan være viktig fordi kunnskapen kan bidra til å styrke organisasjonens potensial for læring og videre utvikling, slik at sykehjemmene blir i stand til å imøtekomme fremtidige utfordringer med styrket kompetanse.

\section{Referanser}

Abelsen, B., Gaski, M., Nødland, S. I. \& Stephansen, A. (2014).

Samhandlingsreformens konsekvenser for det kommunale pleie- og omsorgstilbudet (Rapport IRIS - 2014/382). Stavanger: International Research Institute of Stavanger.

André, B., Sjøvold, E., Rannestad, T. \& Ringdal, G. I. (2014). The impact of work culture on quality of care in nursing homes - a review study. Scandinavian Journal of Caring Science, 28(3), 449-457. https://doi.org/10.1111/scs.12086 
Arntzen, E. (2014). Ledelse og kvalitet i helsetjenesten. Oslo: Gyldendal Akademisk.

Berg, L. N. (2015). Multifaglig ledelse - hybridisering i sykehusledelse etter NPMreformer (Doktorgradsavhandling). Universitetet i Bergen, Bergen.

Berg, L. N., Byrkjeflot, H. \& Kvåle, G. (2010). Hybridledelse i sykehus - en gjennomgang av litteraturen. Nordiske Organisasjonsstudier, 12(3), 30-49.

Birkinshaw, J. (2014). Bli en bedre sjef. Hvorfor god ledelse er så vanskelig. Oslo: Cappelen Damm Akademisk.

Bruvik, F., Drageset, J. \& Abrahamsen, J. F. (2017). From hospitals to nursing homes - the consequences of the Care Coordination Reform. Sykepleien forskning, 12(60613), e60613.

Bryman, A. (2015). Social research methods. Oxford, England: Oxford University Press.

Christensen, T. \& Lægreid, P. (2011). The Ashgate Research Companion to New Public Management. London: Routledge.

Cummings, G. G., MacGregor, T., Davey, M., Lee, H., Wong, C. A., Lo, E., Muise, M. \& Stafford, E. (2010). Leadership styles and outcome patterns for the nursing workforce and work environment: A systematic review. International Journal of Nursing Studies, 47(3), 363-385. https://doi.org/10.1016/j.ijnurstu.2009.08.006

Denzin, N. K. \& Lincoln, Y. S. (2017). The SAGE handbook of qualitative research (5. utg.). Thousand Oaks, CA: Sage.

Engelstad, F. (2005). Hva er makt? Oslo: Universitetsforlaget.

Espedal, B. (2009). Maneuvering space for leadership. Journal of Leadership and Organizational Studies, 16(2), 197-212.

Espedal, B. \& Kvitastein, O. A. (2012). Rom for læring: Betydningen av handlingsrom for ledelse. Magma, 8, 30-30.

Espedal, B., Kvitastein, O. A. \& Grønhaug, K. (2012). When cooperation is the norm of appropriateness: How does CEO cooperative behavior affect organizational performance? British Journal of Management, 23(2), 257-271.

Finkelstein, S. \& Hambrick, D. C. (1996). Strategic leadership: Top executives and their effects on organizations. Minneapolis, MN: West Publishing Company.

Germain, P. B. \& Cummings, G. G. (2010). The influence of nursing leadership on nurse performance: a systematic literature review. Journal of Nursing Management, 18(4), 425-439.

Goffman, E. (1992). Vårt rollespill til daglig: En studie i hverdagslivets dramatikk. Oslo: Pax forlag.

Goffman, E. (2009). Stigma: Om afvigerens sociale identitet (2.utg.). Frederiksberg: Samfundslitteratur.

Hambrick, D. C. \& Finkelstein, S. (1987). Managerial discretion: A bridge between polar views of organizational outcomes. Research in Organizational Behavior, 9, 369-406. 
Hambrick, D. C. \& Mason, P. A. (1984). Upper echelons: The organization as a reflection of its top managers. Academy of Management Review, 9(2), 193-206.

Helse- og omsorgstjenesteloven. (2011). Lov om kommunale helse- og omsorgstjenester m.m. (helse- og omsorgstjenesteloven) (LOV-2011-o6-24-30). Hentet fra https://lovdata.no/dokument/NL/lov/2011-06-24-30

Helbostad, J. L. (2005). Fysisk trening av sykehjemsbeboere - har det noen hensikt? Tidsskriftet for Den norske legeforening, 125(9), 1195-1197.

Hemphil, J. K. \& Coons, A. E. (1957). Development of the leader behavior description questionnaire. I R. M. Stogdill \& A. E. Coons (Red.), Leader behavior: Its description and measurement. Columbus, $\mathrm{OH}$ : Bureau of Business Research.

Hernes, G. (2007). Med på laget: Om New Public Management og sosial kapital i den norske modellen (Fafo-rapport 2007: 09). Oslo: Fafo.

Hope, O. (2015). Mellomlederen. Oslo: Gyldendal Akademisk.

Humphrey, S. E., Nahrgang, J. D. \& Morgeson, F. P. (2007). Integrating motivational, social and contextual work design features: A meta-analytic summary and theoretical extension of the work design literature. Journal of Applied Psychology, 92(5), 1332-1256.

Høie, J. (2005). Sykehjemmenes oppgaver og legens rolle. Tidsskrift for Den norske legeforening, 125(8), 1009-1010.

Jacobsen, D. I. \& Thorsvik, J. (2019). Hvordan organisasjoner fungerer (5. utg.). Bergen: Fagbokforlaget.

Kaplan, R. S. \& Norton, D. P. (1996). The balanced scorecard: Translating strategy into action. Boston, MA: Harvard Business School Press.

Kaufmann, G. \& Kaufmann, A. (2015). Psykologi i organisasjon og ledelse. Bergen: Fagbokforlaget.

Kirkhaug, R. (2013). Verdibasert ledelse. Betingelser for utøvelse av moderne lederskap. Oslo: Universitetsforlaget.

Kotter, J. P. (2012). Leading Change. Brighton, MA: Harward Business Review Press.

Kristoffersen, N. J. (2016a). Sykepleie - kunnskapsgrunnlag og kompetanseutvikling. I N. J. Kristoffersen, F. Nortvedt, E.-A. Skaug \& G. H. Grimsbø (Red.), Grunnleggende sykepleie. Sykepleie - fag og funksjon (Bd. 1). Oslo: Gyldendal Akademisk.

Kristoffersen, N. J. (2016b). Sykepleierens ansvar og arbeidsområder i helsetjenesten. I N. J. Kristoffersen, F. Nortvedt, E.-A. Skaug \& G. H. Grimsbø (Red.), Grunnleggende sykepleie. Sykepleie - fag og funksjon (Bd. 1). Oslo: Gyldendal Akademisk.

Kristoffersen, M. \& Friberg, F. (2016). Transformasjonsledelse og økte effektivitetskrav i sykepleien. Nordic Journal of Nursing Research, 36(1), 13-19.

Kvale, S. (1996). Interviews. An Introduction to qualitative research interviewing. Thousand Oaks, CA: Sage. 
Kvale, S. \& Brinkmann, S. (2015). Det kvalitative forskningsintervju (3.utg.). Oslo: Gyldendal Akademisk.

Lai, L. (2013). Strategisk kompetanseledelse (3.utg.). Bergen: Fagbokforlaget.

Lian, O. S. (2007). Når helse blir en vare: Medikalisering og markedsorientering $i$ helsetjenesten (2. utg.). Kristiansand: Høyskoleforlaget.

Martinsen, K. (2012). Løgstrup og sykepleien. Oslo: Cappelen Damm.

Martinussen, W. (1991). Sosiologisk analyse - en innforing (3. utg.). Oslo: Universitetsforlaget.

Helse- og omsorgsdepartementet. (2009). Samhandlingsreformen - Rett behandling - på rett sted - til rett tid (St.meld. nr. 47 (2008-2009)). Hentet fra https://www.regjeringen.no

Helse- og omsorgsdepartementet. (2011). Nasjonal helse- og omsorgsplan (2011-2015) (Meld. St. 16 (2010-2011)). Hentet fra https://www.regjeringen.no

Helse- og omsorgsdepartementet. (2015). Fremtidens primorhelsetjeneste - noerhet og helhet (Meld. St. 26 (2014-2015)). Hentet fra https://www.regjeringen.no

Helse- og omsorgsdepartementet. (2016). Verdier i pasientens helsetjeneste - Melding om prioritering (Meld. St. 34. (2016-2016)). Hentet fra https://www.regjeringen.no Merton, R. K. (1968) Social theory and social structure. New York: The Free Press.

Morgeson, F. P. \& Humphrey, S. E. (2006). The work design questionnaire (WDQ): Developing and validating a comprehensive measure for accessing job design and the nature of work. Journal of Applied Psychology, 91(6), 1321-1339.

Nonaka, I. \& Takeuchi, H. (1995). The knowledge-creating company. New York: Oxford University Press.

Nortvedt, M. W., Jamtvedt, G., Graverholt, B., Nordheim, L. V. \& Reinar, L. M. (2012). Jobb kunnskapsbasert! En arbeidsbok (2. utg.). Oslo: Akribe.

Nortvedt, P. \& Grønseth, R. (2016). Klinisk sykepleie - funksjon, ansvar og kompetanse. I D.-G. Stubberud, R. Grønseth \& H. Almås (Red.), Klinisk sykepleie 1 (5. utg.). Oslo: Gyldendal Akademisk.

Oldham, G. R. \& Hackman, J. R. (2010). Not what it was and not what it will be: The future of job design research. Journal of Organizational Behavior, 31(2-3), 463-479.

Orvik, A. (2015). Organisatorisk kompetanse: Innføring i profesjonskunnskap og klinisk ledelse. Oslo: Cappelen Damm Akademisk.

Pedersen, K. R. \& Tingvoll W.-A. (2014). Komptanseutfordringer i sykehjem. I B. L. L. Kassah, M.-A. Tingvoll \& K. A. Kassah (Red.), Samhandlingsreformen under lupen. Bergen: Fagforlaget.

Pfeffer, J. \& Salancik, G. R. (1978). The external control of organizations: A resource dependence perspective. New York: Harper \& Row.

Pfeiffer, R. (2002). Sykepleier og leder: Den administrative og den faglige sykepleielederens funksjon. Bergen: Fagbokforlaget. 
Polanyi, M. (2009). The tacit dimension. Chicago, IL: University of Chicago Press.

Rasmussen, B. (2011). Med frihet til å lede? Styring og ledelse i kommunale omsorg. Magma. Econas tidsskrift for økonomi og ledelse, 1, 65-72.

Røvik, K. A. (2007). Trender og translasjoner: Ideer som former det 21. århundrets organisasjon. Oslo: Universitetsforlaget.

Schiefloe, P. M. (2011). Mennesker og samfunn. Innføring i sosiologisk forståelse. Bergen: Fagbokforlaget.

Schönfelder, W., Andersen, S. T. \& Kane, A. A. (2018). Muligheter og begrensninger for profesjonsutøvernes handlingsrom i de kommunale barneverntjenestene. I W. Schönfelder, S. T. Andersen \& A. A. Kane (Red.), Handlingsrom $i$ barnevernet. Muligheter og begrensninger for profesjonsutøveren (s. 275-280). Bergen: Fagbokforlaget.

Selznick, P. (1984). Leadership in administration: A sociologicel interpretation. Oakland, CA: University of California Press.

Stewart, R. (1989). Studies of managerial jobs and behavior - the ways forward. Journal of Management Studies, 26(1), 1-10.

Strand, T. (2007). Ledelse, organisasjon og kultur (2. utg.). Bergen: Fagbokforlaget.

Sørensen, E. E. (2006). Sygeplejefaglig ledelse: En empirisk undersøgelse af samspil mellem ledelse og faglighed $i$ ledende sygeplejerskers praksis i dansk sygehusvoesen (Doktorgradsavhandling). Aarhus universitet, Aarhus.

Tingvoll, W.-A., Sæterstrand, T. \& Fredriksen, S.-T. D. (2010). Kompetanse i tiltakskjeden - avdelingslederes erfaringer om utskrivninger av elder pasienter fra sykehus. Nordic Journal og Nursing, 30(1), 29-34.

Tingvold, L. \& Magnussen, S. (2018). Økt spesialisering og differensiering i sykehjem. Tidsskriftet for omsorgsforskning, 4(2), 11-17.

Tingvoll, W.-A., Pedersen, K. R. \& Nymo, R. I. J. (2018). Ny praksismodell gjorde studentene bedre i ledelse og organisering. Sykepleien forskning. https://doi. org/10.4220/Sykepleienf.2018.73575

Tingvoll, W.-A., Sæterstrand, T. M. \& Fredriksen S.-T. D. (2010). Kompetanse i tiltakskjeden - avdelingslederes erfaringer om utskrivninger av eldre pasienter fra sykehus. Vård i Norden, 30(1), 29-34.

Tingvoll, W.-A., Sæterstrand, T. \& McClusky, L. M. (2016). The challenges of primary health care nurse leaders in the wake of New Health Care Reform in Norway. BMC Nursing, 15, 66. https://doi.org/10.1186/s12912-016-0187-x

Valentine, S., Godkin, L. \& Varca, P. E. (2010). Role conflict, mindfulness, and organizational ethics in an education-based healthcare institution. Journal of Business Ethics, 94, 455-469. https://doi.org/10.1007/s10551-009-0276-9

Weber, M. (1971). Makt og byråkrati. Oslo: Gyldendal. 
Wong, C. A. \& Cummings, G. G. (2007). The relationship between nursing leadership and patient outcomes: A systematic review. Journal of Nursing Management, 15(5), 508-521.

Wong, C. A., Cummings, G. G. \& Ducharme, L. (2013). The relationship between nursing leadership and patient outcomes: A systematic review update. Journal of Nursing Management, 21(5), 709-724.

Wyller, T. B. \& Haukelien, H. (2017). Ny helsepolitikk. Det finnes løsninger. Oslo: Dreyers forlag.

Ytrehus, S. \& Nuland, B. R. (2007). Gull eller gråstein. Status for rekruttering og kompetanseutvikling i helse- og omsorgstjenestene (Fafo-rapport 2007: 21). Hentet fra https://fafo.no/media/com_netsukii/20021.pdf

Yukl, G. (2019). Leadership in organizations. (8. utg.). New York: Pearson. 



\title{
Utøvelse av kunnskapsbasert praksis i sykehjem
}

\section{Karin Ravn Pedersen og Wivi-Ann Tingvol/}

\author{
UiT Norges arktiske universitet
}

\begin{abstract}
Evidence-based practice (EBP) is one of the core skills in nursing, and it has received increased attention in official documentation and parliamentary announcements.

The objective of this chapter is to develop knowledge about how EBP can be employed in nursing homes. The chapter is based on the experiences of nursing students during their project work on health promotion and prevention in a nursing home. The data are based on 18 students' written evaluations of their practical studies, a focus group discussion with 4 of these 18 nursing students, and individual interviews with 4 leaders conducted in 2018.

This study shows that both the leaders of the nursing homes and the students themselves acknowledge the need for occupational practice to be evidence-based.

Resistance experienced by the nursing home staff may be a barrier to the application of EBP. The students experienced the project work as an opportunity to immerse themselves in a specific and well-defined theme using EBP tools.
\end{abstract}

Keywords: evidence-based practice, nursing home, project work, leaders, nursing students

\section{Introduksjon}

Kunnskapsbasert praksis (KBP) er et av kompetanseområdene i sykepleien, og i forskrifter for sykepleierutdanningen blir KBP fremhevet som et virkemiddel for omsorgsfull og faglig forsvarlig sykepleie (forskrift om nasjonal retningslinje for sykepleierutdanning, 2019). KBP innebærer å ta faglige avgjørelser basert på forskningsbasert kunnskap, erfaringsbasert

$1 \quad$ Forfatterne er likeverdige bidragsytere

Sitering av denne artikkelen: Pedersen, K. R. \& Tingvoll, W.-A. (2020). Utøvelse av kunnskapsbasert praksis i sykehjem. I B. L. L. Kassah, H. Nordahl-Pedersen \& W.-A. Tingvoll (Red.), Handlingsrom for profesjonalisert velferd: Kommunale tjenester for helse, omsorg og barnevern (Kap. 7, s. 155-175). Oslo: Cappelen Damm Akademisk. https://doi.org/10.23865/noasp.114.ch7 
kunnskap og pasientenes ønsker og behov samt har betydning for faglig kvalitet og utvikling av sykepleiefaget (Nortvedt, Jamtvedt, Graverholt, Nordheim \& Reinar, 2012). Helsetjenestene får stadig flere sammensatte faglige utfordringer, og det vil dermed være avgjørende for kvaliteten at tjenestene benytter kunnskap fra ulike kilder på en systematisk måte. Som et virkemiddel for å møte disse sammensatte utfordringene har KBP fått økt oppmerksomhet og fremheves i offentlige dokumenter og stortingsmeldinger (forskrift om ledelse og kvalitetsforbedring i helsetjenesten, 2016; Helse- og omsorgsdepartementet, 2015, 2018; Kunnskapsdepartementet, 2012).

Det viser seg at det er en lang prosess fra utvikling av ny kunnskap til at kunnskapen implementeres i helsetjenesten (Røkholt, Davidsen, Johnsen \& Hilli, 2017). I rapporten HelseOmsorg 21 fremheves det at ny kunnskap fra forskning samt samarbeid mellom tjenesten og utdanningen er en forutsetning for en kunnskapsbasert helse- og omsorgstjeneste (Helse- og omsorgsdepartementet, 2014). Sykepleierutdanningen har ansvar for at studentene blir bevisst på KBP som en viktig kompetanse i sykepleie (Christie, Hamill \& Power, 2012). Det teoretiske grunnlaget i KBP får studentene gjennom undervisning i løpet av studiet. Teoretisk undervisning har vist seg ikke å være tilstrekkelig for at sykepleiestudenter skal kunne anvende kunnskapsbaserte arbeidsformer (Smith-Strøm, Oterhals, Rustad \& Larsen, 2012). Studentene må erfare at KBP er integrert $\mathrm{i}$ helsetjenesten, og det fordrer at KBP er et tema i studentenes praksisstudier i løpet av utdanningen. Studentenes deltagelse i kvalitetsforbedrende prosjekter kan bidra til større faglig forståelse og innsikt i anvendelse av KBP (Erichsen, Røkholt \& Utne, 2016; Pedersen, Tingvoll \& Nymo, 2018; Røkholt, Davidsen, Johnsen \& Dihle, 2020; Stone \& Rowles, 2007).

Vi har tidligere gjennomført og publisert tre studier som omhandler praksisperioden i sykehjem, sjette semester. (Pedersen et al., 2018; Tingvoll, Pedersen \& Nymo, 2018; Pedersen \& Tingvoll, 2019). I disse tre artiklene er faglig kvalitet og kvalitetsutvikling belyst, mens KBP er nevnt, men ikke fremhevet. Derfor ønsket vi å gjennomføre en oppfølgingsstudie med større oppmerksomhet på KBP knyttet til studentenes gjennomføring av prosjektarbeid i sykehjem i sjette semester. Prosjekt med søkelys på helsefremmende og forebyggende sykepleie ble valgt 
fordi denne tematikken har fått økt oppmerksomhet (Helse- og omsorgsdepartementet, 2018).

Dette kapitlet baseres på kvalitative data fra sykepleiestudenters evaluering av sin praksisperiode i sjette semester samt data fra en fokusgruppediskusjon med fire studenter og fra individuelle intervjuer med fire enhetsledere med ansvar for sykehjem. Hensikten med kapitlet er å utvikle kunnskap om hvordan KBP kan anvendes i sykehjem, og om hvilke handlingsrom (se kapittel 1) som er til stede for å kunne anvende KBP.

Problemstilling: Hva preger handlingsrommet til ledere og sykepleiestudenter når det søkes å anvende KBP $i$ helsefremmende og forebyggende prosjektarbeid i sykehjem?

\section{Kunnskapsbasert praksis (KBP)}

Kunnskapsutvikling med KBP som omfatter forskning, erfaring og brukermedvirkning, er sentrale virkemidler i beslutningsgrunnlaget for å innfri krav til faglig utvikling og styrking av sykehjemmene. Det forutsetter bevisstgjøring på KBP, og at det anvendes i et kontinuerlig forbedringsarbeid slik at kvaliteten i helse- og omsorgstjenesten til enhver tid opprettholdes (Helse- og omsorgsdepartementet, 2014, 2018). KBP handler om å kunne ta faglige avgjørelser basert på systematisk innhenting av forskningsbasert kunnskap, erfaringskunnskap og pasientens behov og ønsker i den gitte situasjonen (Nortvedt et al., 2012). Forskningsbasert kunnskap er oppnåelse av økt kunnskap gjennom en systematisk kreativ virksomhet. Det skilles mellom grunnforskning og anvendt forskning. Grunnforskning observerer fakta eller fenomener uten sikte på spesiell bruk, mens anvendt forskning ser på bestemte praktiske mål eller anvendelser. I KBP vil søkelyset være rettet mot anvendt forskning (Nortvedt et al., 2012). Forskningsbasert kunnskap alene er imidlertid ikke tilstrekkelig for at sykepleiere skal kunne ta gode faglige avgjørelser. Vurderinger og handlinger skal også baseres på faglig skjønn eller erfaringsbasert kunnskap. Erfaringsbasert kunnskap, også kjent som skjønn eller praksiskunnskap, bygger på kunnskap som oppnås gjennom å praktisere sykepleie. Kunnskapen utveksles gjennom erfaringer og refleksive prosesser 
sammen med andre. Pasientenes synspunkter skal vektlegges i valg av tiltak, og sykepleieren har ansvar for å legge til rette for brukermedvirkning gjennom samarbeid med pasienten. Brukermedvirkning bygger på den erfaringsbaserte kunnskapen pasientene har om sitt eget liv, sin helse og fra bruk av ulike tjenester. Pasientenes kunnskap og erfaringer skal aktivt brukes og vektlegges når beslutninger om pasientens livssituasjon fattes. Det kreves dermed et tett samarbeid mellom helsepersonell og pasient (Nortvedt et al., 2012).

I modellen for KBP er de ulike kunnskapskildene satt inn i en bestemt kontekst. Konteksten kan beskrives som den settingen hvor KBP skal anvendes, og rammene sykepleiere arbeider innenfor, har betydning for hvordan yrket utøves (Nortvedt et al., 2012). Arbeidsprosessen for å kunne implementere KBP i klinisk praksis beskrives i seks trinn (Nortvedt et al., 2012). Det første trinnet er refleksjon over egen yrkesutøvelse. Det kan omhandle hva det er i pasientbehandlingen eller pasientomsorgen som må endres eller forbedres. Neste trinn er å kunne formulere gode og presise spørsmål på bakgrunn av refleksjonen. Et presist spørsmål bør inneholde informasjon om hvem vi er interessert $i$, hvilke tiltak vi er interessert $\mathrm{i}$, og hvilke utfall som er av interesse. Trinn tre er å finne forskningsbasert kunnskap gjennom søk i anerkjente databaser og tekstressurser. Det kan være kunnskap innhentet fra rapporter, artikler samt dokumenter av vitenskapelig karakter. Videre er trinn fire kritisk gjennomgang av den litteraturen man finner. Er forskningen relevant, og kan vi stole på resultatene? Det neste trinnet er å integrere anvendbar forskningsbasert kunnskap med erfaringsbasert kunnskap og pasientens preferanser samt overføre den samlede kunnskapen til egen yrkesutøvelse. Siste trinn omhandler evaluering av endringer som iverksettes (klinisk audit) (Helsebibloteket, 2019).

KBP er ikke en selvfølge i sykepleieutøvelsen, og det finnes flere utfordringer og barrierer som gjør at kunnskapsbaserte arbeidsmetoder ikke blir en del av yrkesutøvelsen (Forsberg, 2016). Ifølge Forsberg (2016) kan det være mangel på tid, mangel på personell, mangel på respekt for forskning og motstand mot endring av praksis. Andre forhold, som mangel på datamaskiner, kan gjøre det utfordrende å søke relevant kunnskap. En annen utfordring er ledere som ikke følger opp og implementerer 
oppdatert kunnskap (Forsberg, 2016). Ledernes engasjement i endringer er sentralt fordi forhold som lederne er opptatt av, vil være kulturskapende i organisasjonen (Tingvoll, Sæterstrand \& McClusky, 2016).

Sykepleierutdanningen har en sentral rolle med hensyn til å integrere kunnskapsbaserte arbeidsformer og opplæring gjennom hele studiet (forskrift om nasjonal retningslinje for sykepleierutdanning, 2019). Studentene må introduseres for modellens ulike trinn og kombinere teoretisk kunnskap og praktiske ferdigheter, både i utdanning og i utøvelse av sykepleie i praksisstudier (Erichsen et al., 2016). Ifølge HelseOmsorg21 svarer dagens utdanninger i for liten grad til de utfordringene helsevesenet står overfor. Spesielt gjelder det kunnskap om kvalitetsarbeid og omstillingsevne, der det pekes på manglende samspill mellom utdanning, praksis og forskning (Helse- og omsorgsdepartementet, 2014). Samtidig erfarer lærere og studenter at praksisfeltet i mindre grad er faglig oppdatert eller arbeider kunnskapsbasert, og det viser seg at sykepleiere kan være negativt innstilt til å anvende forskning (Erichsen et al., 2016). Sykehjem er en god læringsarena for studenter i å kunne anvende KBP. Arbeidsmetoden kan bidra til å øke det faglige engasjementet og til å finne løsninger på ulike problemstillinger (Erichsen et al., 2016). Tett samarbeid mellom utdanning og sykehjem er avgjørende for å motivere både studenter og sykepleiere til å ta i bruk KBP (Erichsen et al., 2016; Pedersen et al., 2018).

\section{Sykehjem som praksisfelt}

Sykehjemmene er en del av kommunens helse- og omsorgstjeneste, og har de siste årene fått tilført nye oppgaver (Helse- og omsorgsdepartementet, 2009). Etter samhandlingsreformen har sykehjemmene pasienter med omfattende behov for medisinsk behandling, rehabilitering og palliativ omsorg og pleie som følge av kortere liggetid i sykehus (Bruvik, Drageset \& Abrahamsen, 2017; Pedersen \& Tingvoll, 2014). Økt andel pasienter med demens samt kroniske og sammensatte lidelser har ført til at sykepleiere har fått større faglig ansvar for å kunne ivareta pasientenes behov for pleie, omsorg og behandling (Bergland, Vibe \& Martinussen, 2010). De endringene som sykehjemmene har vært gjennom, har ført til økt arbeidsmengde for de ansatte. Sykepleiere beskriver 
en hektisk arbeidshverdag med flere delegerte behandlingsoppgaver. Det oppleves positivt å bli tillagt nye arbeidsoppgaver fordi større faglige utfordringer kan gi økt motivasjon i arbeidet. Samtidig har sykepleierne fått økt arbeidspress fordi det ikke er blitt tilført flere ressurser, og det er i liten grad blitt satset på å heve kompetansen blant de ansatte (Bruvik et al., 2017; Ingstad, 2010; Pedersen \& Tingvoll, 2014). Dette har ført til at sykehjemmene har store utfordringer med å rekruttere sykepleiere, med påfølgende uttalt bruk av ufaglært arbeidskraft (Gautun, Øien \& Bratt, 2016).

Mangel på fagpersonell og tidspress kan føre til at faglig forsvarlighet ikke blir godt nok ivaretatt, fordi utøvelse av KBP blir nedprioritert (Pedersen \& Tingvoll, 2019). Å jobbe kunnskapsbasert er heller ikke tradisjon i sykehjem, selv om nye retningslinjer og føringer i eldreomsorgen er tydelig på at praksis skal være kunnskapsbasert (Berland, Gundersen \& Bentsen, 2012; Helse- og omsorgsdepartementet, 2012; Stokke, Olsen, Espehaug \& Nortvedt, 2014). Lederne har det overordnede ansvaret for kontinuerlig forbedringsarbeid i sykehjem. En av forutsetningene for at KBP aktualiseres i sykehjem, er at ledere legger til rette for at ansatte kan jobbe kunnskapsbasert (forskrift om ledelse og kvalitetsforbedring i helsetjenesten, 2016; Røkholt et al., 2017). Lederne i sykehjem forventer at sykepleierne skal være opptatt av å utvikle faget, samtidig som det er mangel på kompetanseplaner og strukturerte planer for å arbeide med kunnskapsutvikling (Pedersen \& Tingvoll, 2019). Det er avgjørende at lederne viser kunnskap og engasjement hvis sykehjemmet skal lykkes med implementering av KBP (Røkholt et al., 2017).

\section{Helsefremmende og forebyggende prosjekt}

Sykepleierutdanningen har en ni uker lang praksisperiode i sykehjem i sjette semester. Læringsutbytte for praksisperioden er primært ledelse og administrasjon av sykepleie til pasienter og pårørende. En del av praksisperioden er satt av til gjennomføring av prosjektarbeid med tema innen helsefremming og forebygging. Et prosjekt er en unik og målrettet arbeidsoppgave med gitte tidsrammer som krever midlertidig organisasjon, med en samordnet menneskelig innsats (Hauken, 2019). 
Formålet med prosjekt som metode er å gjøre den teoretiske undervisningen virkelighetsnær. Studentene skal jobbe kunnskapsbasert og foreslå løsninger til aktuelle problemer. Gjennom å arbeide med prosjektet forventes det at studentene utvikler kompetanse innen sykepleiefaglig kunnskap, samarbeid, problemløsning, refleksjon og kritisk tenkning (Lycke, 2016). Studentenes kunnskap utvikles gjennom refleksjon og samhandling med andre i et praksisfellesskap (kontekst) og er forankret i en sosiokulturell kunnskapstradisjon (Säljö, 2016). Læring i et sosiokulturelt perspektiv er situert og kan ses på som en sosial aktivitet der kunnskap blir konstruert gjennom dialog og samhandling med andre (Dysthe, 2001).

Studentene i denne studien organiserer seg i grupper med to til fire studenter i hver gruppe, og de arbeider med problemstillinger fra praksisfeltet for å kunne utforske og forstå faglige utfordringer (Lycke, 2016). Valg av tema og problemstilling skjer i tett dialog med ledelsen og ansatte ved sykehjemmet. På denne måten blir valg av problemstilling en interaksjon mellom sykehjemmets interesser, praksisstudiets læreplan og studentenes faglige interesser (Hansen \& Kahn, 2016). Prosjektet tar utgangspunkt i avviksmeldinger ved den aktuelle enheten eller avdelingen, og det skal ha søkelys på forbedringsarbeid rettet mot helsefremming og forebygging. Gjennomføringen av prosjektet skal baseres på trinnene i kunnskapsbasert praksis - refleksjon, spørsmålsformulering, litteratursøk, kritisk vurdering, anvendelse og evaluering av tiltak (Nortvedt et al., 2012). Lærerne veileder studentene i arbeidsprosessen og gir tilbakemelding på prosjektbeskrivelsen. Planen for prosjektet skal beskrive hensiktsmessig disponering av tid, arbeidsmetoder og presentasjonsform (Lycke, 2016). Det er behovet til de enkelte studentgruppene som avgjør hvorvidt det er nødvendig med ytterligere veiledning og involvering fra lærer. Gjennom prosjektarbeid i helsefremmende og forebyggende forbedringsarbeid blir studentene utfordret til tverrfaglig samhandling med helsepersonell i en presset hverdag (Tingvoll et al., 2018). Prosjektarbeidet foregår gjennom hele praksisperioden på ni uker, og det avsluttes med en oppgave som formidles både skriftlig og muntlig til det aktuelle sykehjemmet. Studier viser at ved å arbeide med prosjekter i praksis lærer studentene å reflektere kritisk over egen yrkesutøvelse, og de får innsikt i betydningen av å 
bruke forskningsbasert kunnskap i utøvelsen av sykepleie. Det viser seg at praksisfeltet gjør seg nytte av resultatene av prosjektene i forbedringsarbeidet i sykehjemmet (Erichsen et al., 2016; Stone \& Rowles, 2007). Studentene presenterer ny forskning ut fra aktuelle temaer som ikke blir prioritert i en travel hverdag. Studentprosjekter kan dermed stimulere til videre arbeid med å benytte KBP for å endre og forbedre sykepleien i enheten (Stone \& Rowles, 2007).

\section{Metode}

For å belyse problemstillingen «hva preger handlingsrommet til ledere og sykepleiestudenter når det søkes å anvende KBP i helsefremmende og forebyggende prosjektarbeid i sykehjem?» har vi benyttet et kvalitativ design. Vi valgte å samle data fra flere kilder: studenters skriftlige evaluering av praksisperioden, en fokusgruppediskusjon samt reanalyse av tidligere intervjuer med enhetsledere i sykehjem.

Vi ønsket å få frem studentenes erfaringer med prosjektarbeid i sykehjem, samt hvilke handlingsrom de erfarte ved anvendelse av KBP, og vi valgte å benytte skriftlige evalueringer som viktigste kilde for datainnsamling. Forfatterne av kapitlet utarbeidet et elektronisk evalueringsskjema med åpne spørsmål. Det ble sendt forespørsel til 35 studenter som hadde gjennomført praksis i sjette semester. 18 av disse besvarte evalueringen. Spørsmålene var knyttet til hvordan de så på muligheten for å arbeide kunnskapsbasert, og til deres erfaringer med prosjektarbeid som metode. Besvarelsene på evalueringsskjemaet var anonyme.

For å få utdypede svar i evalueringen som omhandlet KBP og studentenes handlingsrom i anvendelse av KBP, gjennomførte vi en fokusgruppediskusjon med fire studenter. Fokusgruppediskusjon ble valgt fordi diskusjoner omkring avgrensede temaer gir muligheter for nyansert informasjon om informantenes opplevelser (Halkier,2010). Studentene som deltok i fokusgruppediskusjonen, hadde vært i praksis ved forskjellige sykehjem, og på denne måten kunne vi få frem ulike erfaringer. Tema i diskusjonen var studentenes erfaringer med å jobbe kunnskapsbasert i sykehjem, samt hvordan de erfarte gjennomføring av prosjektarbeid. Fokusgruppediskusjonen ble foretatt på et møterom ved studiestedet som 
blir brukt til studentveiledning, og den varte i cirka 90 minutter. Diskusjonen ble ledet av en moderator, og en av forfatterne av denne artikkelen deltok som observatør. Moderator stilte spørsmål underveis i diskusjonen, mens observatøren noterte og bidro med oppfølgingsspørsmål. Det var god dynamikk i gruppen, og studentene deltok aktivt i diskusjon og refleksjon. Fokusgruppediskusjonen ble tatt opp digitalt og transkribert ordrett.

For å belyse ledernes forståelse av KBP og deres handlingsrom i sykehjem ble tidligere semistrukturerte intervjuer reanalysert. Intervjuene var utført i 2018 med fire enhetsledere fra fire ulike sykehjem (Pedersen \& Tingvoll, 2019). I intervjuene ble oppmerksomheten rettet mot ledernes erfaringer med faglig ledelse, samarbeid med studiestedet og KBP.

\section{Analyse}

Analysen av datamaterialet er utført etter inspirasjon fra Kvale og Brinkmann (2015) sin beskrivelse av innholdsanalyse. Studentenes evalueringer ble først analysert ved å lese gjennom materialet flere ganger og ved å dra ut meningsbærende enheter i henhold til hensikten med studien. Etter kategorisering av data fra evalueringen ble det utarbeidet tema for fokusgruppeintervju, som ble gjennomført før videre analyse av alle dataene fra studentene. Videre ble intervjuene fra lederne reanalysert ut fra studiens hensikt og problemstilling. Datamaterialet fra studentene og lederne ble gjennomlest av begge forfatterne gjentatte ganger. I den første fasen av analysen ble meningsbærende enheter fra alle datakildene identifisert og katalogisert. I neste fase ble meningsbærende enheter formulert i fortettet utgave (Kvale \& Brinkmann, 2015). I den siste fasen ble meningene fortolket ut fra studiens hensikt. I analyseprosessen har forfatterne vært bevisst egen forforståelse. Begge forfatterne er sykepleiere og har lang erfaring som lærere og veiledere for sykepleiestudentene. Følgende temaer ble analysert frem:

- Handlingsrommet preges av ulikt ståsted i anvendelse av KBP.

- Handlingsrommet begrenses av opplevd motstand hos personalet.

- Handlingsrommet kan utvides gjennom prosjektarbeid. 


\section{Etikk}

Denne studien (nr. 866849) er godkjent av NSD - Norsk senter for forskningsdata. Alle studentene (35) ble tilskrevet og informert om hensikten med studien i forkant av evalueringen av praksisperioden, og om at de kunne trekke seg underveis mens studien ble gjennomført, uten konsekvenser. Informasjonen til studentene ble gitt av forfatterne av kapitlet.

Deltagerne i fokusgruppen ga skriftlig samtykke og ble informert om retten til å trekke seg hvis de ønsket det. Personidentifiserbare opplysninger er anonymisert, og data er lagret etter gjeldende retningslinjer.

\section{Studiens styrke og begrensning}

Datamaterialet fra sykepleiestudentene (evalueringer og fokusgruppediskusjon) er samlet inn kort tid etter avsluttet praksis på ni uker, slik at studentene hadde nærhet til praksiserfaringene, noe som styrker studien. Studentene hadde gjennomført praksisperioden ved flere ulike sykehjem, noe som kan gi et bredere bilde med tanke på gjennomføring av prosjektet og erfaringene av deres handlingsrom for anvendelse av KBP. Enhetslederne hadde deltatt i utviklingen av innholdet i studentenes læreplan, og på den måten var de godt kjent med faglige krav til studentenes praksisperiode i sjette semester.

Studien er basert på et begrenset datamateriale, noe som er en svakhet. Det var ikke alle studentene som evaluerte sykehjempraksis (18 av 35), og det kan være at de studentene som var mest positivt innstilt, også ga skriftlige tilbakemeldinger. Det ble gjennomført kun ett fokusgruppeintervju. Forfatterne deltok aktivt i utarbeidelsen av planen for praksis i sykehjem og var veiledere underveis i praksisperioden. Dette kan være en svakhet fordi det skaper ulike roller i prosessen, noe vi har vært bevisst på gjennom denne studien.

\section{Funn og diskusjon}

I dette avsnittet diskuteres funn for å belyse hva som preger handlingsrommet når studentene søker å anvende KBP i helsefremmende og 
forebyggende prosjektarbeid. Funnene blir presentert og diskutert i følgende rekkefølge:

- Handlingsrommet preges av ulikt ståsted i anvendelse av KBP.

- Handlingsrommet begrenses av opplevd motstand hos personalet.

- Handlingsrommet kan utvides gjennom prosjektarbeid.

\section{Handlingsrommet preges av ulikt ståsted $\mathrm{i}$ anvendelse av KBP}

Enhetslederne ser nødvendigheten av at sykehjem som praksisfelt tar ansvar for å gjøre kunnskapsbasert tenkning og arbeidsformer til en del av hverdagen. En av lederne sa: «Det er jo dit vi prøver å komme, men akkurat ordet kunnskapsbasert praksis bruker vi jo ikke.» En annen uttrykte: «Vi må jo få kunnskapsbasert praksis implementert hos alle for å skjønne hvorfor vi gjør det.» En leder sa: «Jeg tenker at studentene kanskje kan hjelpe til å vise og bruke kunnskapsbasert praksis.» En sa det slik: «Studentene må jo møte praksis som snakker om å være kunnskapsbasert. At ikke bare studentene gjør det, men at vi også gjør det.» Disse utsagnene kan tolkes som at enhetslederne mangler en klar og entydig forståelse av innholdet i begrepet KBP, og at KBP dermed er lite implementert i sykehjem. Det kan synes som om lederne er opptatt av at studentene bør møte en institusjon som er bevisst på KBP, samtidig som det kan synes å være forventninger til at studentene skal bidra med sine kunnskaper i arbeidet med innføring av KBP.

Studentene er i en studiesituasjon og skal tilegne seg erfaringer med å benytte KBP. En student (fokusgruppe [FG]) sier: «Kunnskapsbasert praksis er helt avgjørende for å kunne utøve god sykepleie ... man er nødt til å oppdatere seg, kunnskapen utvikler seg stadig.» En annen student (evaluering [EV]) uttrykker: «Kunnskapsbasert praksis er et godt krav, men effektivisering ødelegger den beste arenaen for å kunne jobbe kunnskapsbasert i stellesituasjonen.» En student (FG) sier: «Jeg hadde noe kunnskap å komme med og kunne dele med de andre ... man må tørre å bevisstgjøre seg på den kunnskapen ... og prøve å gjøre ting annerledes.» Dette kan forstås som at studentene er bevisst på viktigheten av KBP for å 
utvikle seg som sykepleiere, Dette kan forstås som at studentene er bevisst på viktigheten av KBP for å utvikle seg som sykepleiere, og på hvor viktig det er å reflektere kritisk over praksiserfaringer. Det kan synes som at studentene er usikre på hvordan de kan synliggjøre sin kompetanse.

Funnene viser at enhetsledere og studenter har ulikt ståsted når det gjelder utøvelse av KBP, noe som vil prege deres handlingsrom. Det kan synes som at KBP ikke er implementert i sykehjemmene, og som at innholdet i begrepet i liten grad er kjent blant ledere og ansatte. Lederne har en sentral rolle i dette arbeidet, og det er avgjørende hvordan lederne legger til rette for at anvendelse av KBP blir integrert i det praktiske arbeidet. En forutsetning for å lykkes er at lederne har avklart hva KBP omhandler, og at det er en felles forståelse i organisasjonen av hensikten med å arbeide kunnskapsbasert (Røkholt et al., 2017). Det forutsetter at lederne selv innehar kunnskaper om arbeidsmetoden, og at de har en positiv holdning til forbedringsarbeid. Lederne må samtidig se nytteverdien i å anvende forskning i sykehjem. KBP som metode må integreres i personalgruppen, og forbedringsområder må følges opp med planer og frister (Røkholt et al., 2017). Hvis lederne ikke ser nødvendigheten av nytenkning og forbedring av yrkesutøvelsen, vil det påvirke motivasjonen til det øvrige personalet. En utfordring for lederne når det gjelder implementering av ny kunnskap og utvikling av faget, kan være begrensninger i deres formelle handlingsrom, som i hovedsak preges av økonomi og administrative oppgaver. Handlingsrommet kan også bli påvirket av at lederne møter stadige krav til effektivisering og ressursutnyttelse (Bastøe, Dahl \& Larsen, 2002; Busch, Johnsen, Klausen \& Vanebo, 2001). Når mye av ledernes tid går med til administrasjon, kan utfordringen bli å sette av tid til fagutvikling og forbedringsarbeid. Samtidig stilles det stadig nye krav til forbedring i sykehjem, uten at de blir tilført ressurser (Ingstad, 2010; Helse- og omsorgsdepartementet, 2018)). Dette kan føre til at utviklingsarbeid og nytenkning blir nedprioritert. Lederne kommer i et krysspress mellom krav og forventninger fra sentrale myndigheter og ansatte (Tingvoll et al., 2016).

Empirien viser at lederne ser studentene som en ressurs som kan bidra til å øke kompetansen i sykehjemmet fordi de bidrar med oppdatert teoretisk kunnskap. Ledernes forventninger til studentene kan 
gå på bekostning av studentenes læringsutbytte fra praksisperioden (Pedersen et al., 2018). Imidlertid stiller utdanningen krav til at studentene aktivt anvender KBP og bidrar med faglige innspill i sykehjemmet. En utfordring er at studentenes handlingsrom kan bli begrenset ved at sykehjem ikke innfrir kvaliteten som forventes til studentens praksisopplæring (Tingvoll et al., 2018). Empirien viser at studentene anser KBP som helt nødvendig i utøvelsen av sykepleie. De bemerker likevel at deres handlingsrom utfordres fordi hverdagen preges av mange arbeidsoppgaver og stort tidspress. Studentene er i løpet av utdanningen blitt utfordret til å reflektere kritisk over erfaringer i sykepleieutøvelsen og til å anvende modellen for KBP. Modellens ulike trinn tydeliggjør hvordan studentenes arbeidsprosess skal kunne gjennomføres. Mangel på tid til å søke litteratur og lese artikler, til kritisk vurdering og til implementering av ny kunnskap er av flere beskrevet som den største barrieren for å kunne arbeide kunnskapsbasert (Forsberg, 2016; Smith-Strøm et al., 2012; Stone \& Rowles, 2007). Mangel på tid vil også begrense faglig refleksjon, som er det første trinnet i KBP (Nortvedt et al., 2012). En del av KBP er erfaringsbasert kunnskap som utvikles gjennom kritisk refleksjon, der studentene lærer av egne erfaringer i dialog med andre (Forsberg, 2016; Nortvedt et al., 2012). I en presset arbeidshverdag vil også muligheten for studentenes samhandling med andre sykepleiere og erfaringsdeling reduseres, noe som kan påvirke utviklingen av erfaringsbasert kunnskap.

\section{Handlingsrommet begrenses av opplevd motstand hos personalet}

En barriere for å innføre KBP kan være opplevd motstand fra personalet overfor endringer i sykehjemmet. En av lederne sa: «Det var jo statlige føringer, så vi måtte gjøre endringer ... det tar tid å få alle til å skjønne at rutinene måtte endres ...» En annen av lederne sa det slik: «Ja ... vi er jo der at ... vi har jo gjort det sånn i alle år.» En annen leder sa dette: «De nyutdannede sier ofte at 'vi har lært at forskning viser', men det kan bli møtt med en del motbør. Det er ikke enkelt med den kulturen som er i enheten.» Utsagnene kan tyde på at endringer av yrkesutøvelse og rutiner 
basert på oppdatert kunnskap er en prosess som kan møte motstand, og som tar tid.

Studentene beskriver også opplevd motstand blant personalet overfor endringer og forslag til nye tiltak hos pasientene. En student (FG) sa: «Helsefagarbeidere og ufaglærte sa ofte at ... slik er det vi bruker å gjøre hos denne pasienten ... at det kanskje var vanskelig å snu det.» En annen student (FG) sa det slik: «Sykepleierne var veldig åpen for det, men det var ikke så lett hos de andre ... noen kunne henge seg opp i ... det er ikke slik vi bruker å gjøre det, eller ... det kommer ikke til å funke ... de var mer opptatt av rutiner.» En annen student (EV) utrykte: «Sykepleiere er nysgjerrige - søker etter erfaringer og kunnskap hos studentene.»

Disse utsagnene kan bety at studentene opplever at de utfordres i anvendelse av oppdatert kunnskap på grunn av etablerte arbeidsrutiner. Samtidig kan utsagnene tolkes som at noen i personalet er åpne for nytenkning og nye måter å utføre pleie og behandling på.

Både ledere og studenter beskriver at handlingsrommet for implementering og anvendelse av KBP utfordres og begrenses av opplevd motstand blant personalet. Sykehjemmet som organisasjon preges ofte av faste rutiner, og anvendelse av KBP som redskap i sykehjem er noe som kan utfordre etablerte kulturer. Samtidig er det krav til sykehjemmene at forskning skal anvendes i forbedring og utvikling av sykepleietjenesten (Helse- og omsorgsdepartementet, 2018). Involvering fra ledere i sykehjem er derfor helt avgjørende. Ledere har det overordnede ansvaret for å endre og forbedre rutiner samt for å bidra til kvalitetsutvikling av tjenesten (forskrift om ledelse og kvalitetsforbedring i helsetjenesten, 2016). Ledernes handlingsrom kan bli utfordret fordi personalet uttrykker skepsis mot innføring av KBP samt mot endringer av rutiner og arbeidsmåter. En måte å gjennomføre og lykkes med endringsarbeidet på kan være å fristille ressurspersoner i avdelingen til å bygge opp kompetanse og veilede personalet, slik at de kan se hensikten med å jobbe kunnskapsbasert (Sandvik, Stokke \& Nortvedt, 2011). Kompetanseoppbygging av personalet delegert til-ressurspersoner krever tett dialog med ledere. Det innebærer en felles forståelse av prosessen og arbeidet i implementeringen av KBP (Røkholt et al., 2017). En kritisk og reflekterende holdning til utøvelsen av faget fordrer at det settes av tid og faste møter i arbeidsprosessen. Hvis det 
etableres en kultur der personalet kan diskutere forbedringsarbeid og reflektere over egen yrkesutøvelse, vil forståelsen av nytten av KBP som arbeidsform bli akseptert (Forsberg, 2016). I dette arbeidet må det også skapes rom der erfaringskunnskap settes i sentrum. Den erfaringsbaserte kunnskapen som helsefagarbeidere og ufaglærte innehar, er også viktig og må bli anerkjent. For å lykkes fordres etablering av en felles plattform, samarbeid og en felles forståelse av hva KBP omhandler, og av hvordan alle delene i modellen skal kunne løftes frem.

Sykepleiestudentene er i en læringsprosess, og deres opplevelse av de ansattes skepsis overfor endringer kan begrense studentens handlingsrom i utøvelse og utvikling av egen yrkespraksis. Studentene i vår studie erfarte at det i hovedsak ikke er sykepleiere som utrykker motstand mot endringer, men annet personell med lavere utdanning. En studie viser at nyutdannede sykepleiere kan bli sett på som en trussel i et etablert arbeidsmiljø, blant annet fordi de har oppdatert kunnskap om forskning (Sneltvedt \& Sørlie, 2012). Studentenes oppdaterte kunnskaper kan være en ressurs i avdelingen hvis det skapes handlingsrom for deling av kunnskap. Det kreves støtte fra ledelsen å kunne løfte frem studentens kunnskap i personalgruppen og skape rom for dialog og erfaringsutveksling, noe som kan bidra til mer oppmerksomhet på kvalitetsarbeid og arbeidsformer i avdelingen. Studentene vil kunne oppleve mestring og faglige utfordringer samt et ønske om å jobbe i sykehjem som nyutdannede sykepleiere. Det er en utfordring hvis lederne er avventende med å legge til rette for KBP, fordi det kan medføre usikkerhet hos de nyutdannede sykepleierne, og deres ansvar for kvalitetsutvikling kan bli hindret (Røkholt et al., 2017).

\section{Handlingsrommet kan utvides gjennom prosjektarbeid}

Studentene erfarte prosjektarbeidet gjennom praksisperioden som en lærerik metode, og de beskrev arbeidet med prosjekt som en mulighet til å fordype seg i et konkret, avgrenset tema og til å jobbe kunnskapsbasert. En student (EV) mente: «Prosjektarbeid var en god arena for å kunne finne frem den beste kunnskapen for å kunne tenke helsefremmende og forebyggende i sykehjem.» En student (EV) uttrykte det slik: «Jeg fikk se 
et annet perspektiv enn jeg hadde gjort tidligere. Det å sette seg inn i et konkret tema og gå inn i forskningen på dette var veldig bra. Viser at det er mye å ta tak i på sykehjemmene.»

En annen student (FG) sa: «Prosjektet var veldig relevant, spesielt det å kartlegge avvik. Dette har det vært lite fokus på i utdanningen. Der fikk vi jo frem noe konkret å kunne dra inn forskning og komme med tiltak.» En student (FG) sa det slik: «At kunnskapsbasert praksis er fokus, gjør jo at vi selv får et nytt blikk på hva vi kan tilføre en situasjon.» En student (EV) uttrykte: «Prosjektet blir trukket altfor langt ut. Det blir ikke noe vi jobber med den ene uken, men noe som følger oss gjennom alle ukene, og som stjeler litt for mye energi fra det å jobbe som sykepleier.»

Utsagnene kan tyde på at prosjektarbeid styrker studentenes læring, og at flere ser nødvendigheten av å jobbe kunnskapsbasert. Noen studenter mener imidlertid at prosjektarbeid og KBP tar for mye tid, og at de dermed ikke får utført andre sykepleieroppgaver.

Gjennom arbeid med et definert prosjekt utfordres studentene til å benytte de seks trinnene i kunnskapsbasert praksis, og det pedagogiske opplegget egner seg godt til å utvikle kunnskap om anvendelse av KBP (Hansen \& Kahn, 2016). Studentene kunne fordype seg i et konkret avgrenset tema, og de kunne jobbe sammen om litteratursøk og anbefalinger til forbedring og endring. Det er viktig at studentene ser nytteverdien av prosjekt som metode i forbedringsarbeid. Da har de et bedre utgangspunkt for å fortsette med å jobbe kunnskapsbasert som nyutdannede sykepleiere. Utfordringen med studentenes prosjektarbeid er at aktivitetene blir for lite integrert hos det øvrige personalet. Prosjektet blir noe studentene sysler med, og som ikke angår resten av personalet på sykehjemmet. Det kan ha en sammenheng med hva personalet og praksisveiledere mener er viktig for studentene. En studie viser at sykepleiere mener at studentene heller bør konsentrere seg om å utvikle kliniske ferdigheter, i stedet for å bruke tid på å finne og lese forskningsartikler (Smith-Strøm et al., 2012). Prosjektet som denne studien beskriver, var integrert som en del av en praksisperiode der hoveddelen i læringsutbyttet var knyttet til ledelse og administrasjon av sykepleie på sykehjemmet. Studentene evaluerte prosjektarbeidet gjennomgående svært positivt, men noen mente at det var arbeidskrevende og tok for mye tid fra andre sykepleieoppgaver. 
Dette kan ha sammenheng med en uklar forståelse av hensikten med prosjektarbeid, både hos studenter og hos praksisveiledere.

Deling av prosjektresultater kan motivere studentene og gi en forsterket opplevelse av å være en del av praksisfelleskapet (Bjerga, Rossavik, Gausel, Heggland \& Lode, 2014). Dette fordrer at personalet møter til studentenes fremlegg og bidrar i diskusjonene om forslag til tiltak. Som student er det utfordrende å komme med forslag til endringer fordi man kan bli betraktet som utenforstående, og ikke som en del av personalgruppen. Dette kan bidra til at studentenes kunnskapsbaserte tilnærming ikke blir tatt på alvor. Personalet har ansvar for å følge opp pasientene og må være kjent med forslag til endring og forbedring. Studentene opplevde likevel prosjektet som en god arbeidsmetode som ga innsikt og læring i konkrete problemstillinger. Denne innsikten og den positive innstillingen hos de fleste studentene er med på å styrke deres handlingsrom.

KBP kan bidra til økt forståelse blant personalet om hvorfor forskning, erfaringer og brukernes kunnskap er viktig i endringsarbeid, og det kan gi økt argumentasjon for gjennomføring av endringer. En systematisk innhenting av kunnskap fra de tre kunnskapsnivåene henholdsvis vitenskapelig kunnskap, erfaringskunnskap og brukerkunnskap er sentralt i kvalitetsarbeid i sykehjemmene (forskrift om ledelse og kvalitetsforbedring i helsetjenesten, 2016). Her kan studentenes prosjekt være et konkret bidrag til kvalitetsarbeid. Et annet viktig argument for å løfte frem KBP ligger i et tettere og forpliktende samarbeid mellom studiestedet og sykehjemmene, der felles fagutviklingsprosjekter kan være egnet som metode. Dette er i tråd med tidligere studier (Bjerga et al., 2014; Hansen \& Kahn, 2016). Forslag fra sykehjemmet til konkrete temaer for studentprosjekter kan bidra til at prosjektene blir bedre mottatt. Samtidig kan studentenes teoretiske kompetanse bli sett på som en ressurs i sykehjemmene, og kan føre til at studentene opplever praksisperioden mer utfordrende.

\section{Konklusjon}

Hensikten med kapitlet er å utvikle kunnskap om hvordan KBP kan anvendes i sykehjem, og om hvilke handlingsrom som er til stede for å 
kunne anvende KBP. Vi har diskutert hva som preger handlingsrommet til ledere og sykepleiestudenter når kunnskapsbasert praksis søkes anvendt i helsefremmende og forebyggende prosjektarbeid i sykehjem. Handlingsrommet preges av ulikt ståsted hos ledere og studenter med tanke på anvendelse av KBP. Studentene kommer fra utdanningene med oppdatert kunnskap, og de møter sykehjem der KBP er lite benyttet. Handlingsrommet begrenses ved at personalet i sykehjemmet uttrykker motstand mot endringer av rutiner og arbeidsmåter. Prosjekter med søkelys på kvalitetsforbedring er positivt og kan bidra til å styrke handlingsrommet med tanke på felles forståelse av hva KBP innebærer, og av hvordan ny kunnskap skal kunne anvendes.

Lederne i sykehjem har ansvar for implementering av KBP, og skal de lykkes, må viktigheten av forbedringsarbeid synligjøres og prioriteres. Prosjekt som metode ser ut til å gi sykepleiestudentene større innsikt i KBP. Det er noe som bør videreføres og utvikles i tettere samarbeid med sykehjem som praksisfelt.

\section{Referanser}

Bastøe, P. Ø., Dahl, K. \& Larsen, E. (2002). Organisasjoner i utvikling og endring: oppgaveløsning i en ny tid. Oslo: Gyldendal Akademisk.

Bergland, Å., Vibe, O. \& Martinussen, N. (2010). Hvordan få sykepleiere til å se på sykehjem som en fremtidig arbeidsplass? Sykepleien, 98(1), 52-54. https://doi. org/10.4220/sykepleiens.2010.0005

Berland, A., Gundersen, D. \& Bentsen, S. B. (2012). Evidence-based practice in primary care - An explorative study of nurse practitioners in Norway. Nurse Education in Practice, 12(6), 361-365. https://doi.org/10.1016/j.nepr.2012.05.002

Bjerga, G. H., Rossavik, B. D., Gausel, M. K., Heggland, M. G. \& Lode, K. (2014). Deltagelse i prosjekt i praksisstudiet- en læringsarena for sykepleiestudenter? Klinisk Sygepleje, 28(3), 60-70.

Bruvik, F., Drageset, J. \& Abrahamsen, J. F. (2017). Fra sykehus til sykehjem hva samhandlingsreformen har ført til. Sykepleien Forskning, 12. https://doi. org/10.4220/sykepleienf.2017.60613

Busch, T., Johnsen, E., Klausen, K. K. \& Vanebo, J. (2001). Modernisering av offentlig sektor: New Public Management i praksis. Oslo: Universitetsforlaget.

Christie, J., Hamill, C. \& Power, J. (2012). How can we maximize nursing students' learning about research evidence and utilization in undergraduate, 
preregistration programmes? A discussion paper. Journal of Advanced Nursing, 68(12), 2789-2801. https://doi.org/10.1111/j.1365-2648.2012.05994.x

Dysthe, O. (2001). Sosiokulturelle teoriperspektiv på kunnskap og læring. I O. Dysthe (Red.), Dialog, samspel og loering (s. 33-68). Oslo: Abstrakt forlag.

Erichsen, T., Røkholt, G. \& Utne, I. (2016). Kunnskapsbasert praksis i sykepleierutdanningen. Sykepleien forskning, 11(1), 66-76. https://doi.org/10.4220/ sykepleienf.2016.56829

Forsberg, A. (2016). Omvårdnad på akademisk grund: att utvecklas och ta ansvar. Stockholm: Natur \& kultur Akademisk.

Forskrift om ledelse og kvalitetsforbedring i helsetjenesten. (2016). Forskrift om ledelse og kvalitetsforbedring i helse- og omsorgstjenesten (FOR-2016-10-281250). Hentet fra https://lovdata.no/dokument/LTI/forskrift/2016-10-28-1250

Forskrift om nasjonal retningslinje for sykepleierutdanning. (2019). Forskrift om nasjonal retningslinje for sykepleierutdanning (FOR-2019-03-15-412). Hentet fra https://lovdata.no/dokument/LTI/forskrift/2019-03-15-412

Gautun, H., Øien, H. \& Bratt, C. (2016). Underbemanning er selvforsterkende (NOVA Rapport 6/2016). Hentet fra https://sykepleien.no/sites/default/files/til-trykknova-r6-16-25-mai-2016_2.pdf

Halkier, B. (2010). Fokusgrupper. Oslo: Gyldendal Akademisk.

Hansen, K. K. \& Kahn, P. R. (2016). Studenter som forskerteam. Uniped, 39(03), 228-239. DOI: 10.18261/issn.1893-8981- 2016-03-04

Hauken, M. A. (2019). Prosjektutvikling i helsetjenesten: lang-kort er bedre enn kortlang. Bergen: Fagbokforlaget.

Helse- og omsorgsdepartementet. (2014). HelseOmsorg21: Et kunnskapssystem for bedre folkehelse (Rapport 2014). Hentet fra https://www.regjeringen.no/ contentassets/8ab2fd5c4c7746 dfb51e3f64cd4d71aa/helseomsorg21_strategi_web. pdf?id $=2266705$

Helse- og omsorgsdepartementet. (2015). Omsorg 2020. Regjeringens plan for omsorgsfeltet 2015-2020 (Rapport). Hentet fra https://www.regjeringen.no/ contentassets/af2a24858c8340edaf78a77e2fbegcb7/omsorg_2020.pdf

Helsebibloteket. (2019). Kunnskapsbasert praksis. Hentet fra https://www. helsebiblioteket.no/kunnskapsbasert-praksis

Ingstad, K. (2010). Arbeidsforhold ved norske sykehjem - idealer og realiteter. Nordic Journal of Nursing Research, 30(2), 14-17. https://doi. org/10.1177/010740831003000204

Kvale, S. \& Brinkmann, S. (2015). Det kvalitative forskningsintervju (3. utg.). Oslo: Gyldendal Akademisk.

Lycke, K. H. (2016). Problembasert læring, caseundervisning og prosjektarbeid. I H. I. Strømsø, K. H. Lycke \& P. Lauvås (Red.), Når loering er det viktigste: undervisning i høyere utdanning (2. utg.). Oslo: Cappelen Damm Akademisk. 
Helse- og omsorgsdepartementet. (2012). God kvalitet - trygge tjenester-Kvalitet og pasientsikkerhet $i$ helse- og omsorgstjenesten (Meld. St. 10 (2012-2013)). Hentet fra https://www.regjeringen.no

Kunnskapsdepartementet. (2012). Utdanning for velferd. Samspill i praksis (Meld. St. 13 (2011-2012)). Hentet fra https://www.regjeringen.no

Helse- og omsorgsdepartementet. (2018). Leve hele livet - En kvalitetsreform for eldre (Meld. St. 15 (2017-2018)). Hentet fra https://www.regjeringen.no

Nortvedt, M. W., Jamtvedt, G., Graverholt, B., Nordheim, L. V. \& Reinar, L. M. (2012). Jobb kunnskapsbasert! En arbeidsbok (2. utg.). Oslo: Akribe.

Pedersen, K. R. \& Tingvoll, W.-A. (2014). Kompetanseutfordringer i sykehjem - en studie basert på sykepleieres erfaringer fra hverdagssituasjoner. I B. L. L. Kassah, W.-A. Tingvoll \& A. K. Kassah (Red.), Samhandlingsreformen under lupen (s. 51-64) Bergen: Fagbokforlaget.

Pedersen, K. R. \& Tingvoll, W.-A. (2019). Lederes forventninger til nyutdannede sykepleiere fordrer samarbeid med utdanningen. Geriatrisk sykepleie, 1, 22-29.

Pedersen, K. R., Tingvoll, W.-A. \& Nymo, R. (2018). De kommer som sykepleiere, ikke som studenter. Geriatrisk sykepleie, 1, 28-35.

Røkholt, G., Davidsen, L.-S., Johnsen, H. N. \& Hilli, Y. (2017). Helsepersonells erfaringer med å implementere kunnskapsbasert praksis på et sykehus i Norge. Nordisk sygeplejeforskning, 7(3), 195-208. https://doi.org/10.18261/issn.1892-26862017-03-03

Røkholt, G., Davidsen, L.-S., Johnsen, H. N. \& Dihle, A. (2020). Studenterfaringer med veiledning og læring knyttet til deltagelse i et kvalitetsforbedringsprosjekt på sykehus med kunnskapsbasert praksis som arbeidsform, -en beskrivende og utforskende studie. Nordisk tidsskrift for helseforskning, 16(1). https://doi. org/10.7557/14.5171

Sandvik, G. K., Stokke, K. \& Nortvedt, M. W. (2011). Hvilke strategier er effektive ved implementering av kunnskapsbasert praksis i sykehus. Sykepleien forskning, 6(2), 158-165. https://doi.org/10.4220/sykepleienf.2011.0098

Smith-Strøm, H., Oterhals, K., Rustad, E. C. \& Larsen, T. (2012). Culture crash regarding nursing students' experience of implementation of EBP in clinical practice. Nordic Journal of Nursing Research, 32(4), 55-59. https://doi. org/10.1177/010740831203200412

Sneltvedt, T. \& Sørlie, V. (2012). Valuing professional pride and compensating for lack of experience: Challenges for leaders and colleagues based on recently graduated nurses' narratives. Home Health Care Management \& Practice, 24(1), 13-20. https://doi.org/10.1177/1084822311412592

Helse- og omsorgsdepartementet. (2009). Samhandlingsreformen - Rett behandling - på rett sted - til rett tid (St.meld. nr. 47 (2008-2009)). Hentet fra https://www.regjeringen.no 
Stokke, K., Olsen, N. R., Espehaug, B. \& Nortvedt, M. W. (2014). Evidence based practice beliefs and implementation among nurses: a cross-sectional study. BMC Nursing, 13(1). https://doi.org/10.1186/1472-6955-13-8

Stone, C. \& Rowles, C. J. (2007). Nursing students can help support evidence-based practice on clinical nursing units. Journal of Nursing Management, 15(3), 367-37o.

Säljö, R. (2016). Loring: en introduksjon til perspektiver og metaforer. Oslo: Cappelen Damm Akademisk.

Tingvoll, W.-A., Pedersen, K. R. \& Nymo, R. (2018). Ny praksismodell gjorde studentene bedre i ledelse og organisering. Sykepleien forskning, 13. https://doi. org/10.4220/Sykepleienf.2018.73575

Tingvoll, W.-A., Sæterstrand, T. \& McClusky, L. M. (2016). The challenges of primary health care nurse leaders in the wake of New Health Care Reform in Norway. BMC nursing, 15(1), 1-8. https://doi.org/10.1186/s12912-016-0187-x

UiT Norges arktiske universitet. (2018). Fagplan for bachelor i sykepleie, studiested Narvik. Hentet fra https://uit.no/Content/60626o/cache=20192003143227/ Fagplan\%2oBachelor\%2oi\%2osykepleie\%2oNarvik\%2okull\%2O2017\%20og\%2O senere.pdf 



\title{
KAPITTEL 8
}

\section{$\AA$ A skape handlingsrom for pasientsikkerhet i sykehjem. Sykepleieres erfaringer med å delta i simulering in situ på sykehjem}

\author{
Sari Lindgren, Mona Lahm Høgbakk og Anne Svelstad Evju \\ UiT Norges arktiske universitet
}

\section{Lena Wiklund Gustin}

UiT Norges arktiske universitet og Mälardalens högskola, Sverige

\begin{abstract}
Some patients in nursing homes require extra attention to enable staff to detect and manage deterioration at an early stage. Nursing skills are vital to make systematic observations and assessments of a patient's condition. It is challenging for nurses in nursing homes to make professional decisions without being able to consult other nurses. To improve the quality and safety of health care for patients and their relatives, the focus must be on working to ensure patient safety in nursing homes. Simulation-based learning can be one way to increase reflection on patient safety and develop health professionals' knowledge, skills and attitudes, while protecting patients from unnecessary risks. Simulation-based learning as a method in medical education offers activities that mimic a clinical environment, where students can practice procedures and decision-making and where their critical thinking can be enhanced through role-play, videos or simulators. While simulation often takes place in a simulation center, in situ simulation refers to a learning activity that takes place in participants' everyday work environment where they actually provide patient care. In this chapter, we aim to describe nurses' experiences of in situ simulation and their subsequent reflections on patient safety in nursing homes. Data were collected from two focus groups with 5-6 nurses per group. The transcribed material was analyzed using qualitative content analysis, and two categories were identified that described the nurses' experiences: "to doubt oneself" and "being dependent on others".
\end{abstract}

Keywords: patient safety, nursing, competencies, nursing home, in situ simulation

Sitering av denne artikkelen: Lindgren, S., Høgbakk, M. L., Evju, A. S. \& Wiklund Gustin, L. (2020). A skape handlingsrom for pasientsikkerhet i sykehjem. Sykepleieres erfaringer med å delta i simulering in situ på sykehjem. I B. L. L. Kassah, H. Nordahl-Pedersen \& W.-A. Tingvoll (Red.), Handlingsrom for profesjonalisert velferd: Kommunale tjenester for helse, omsorg og barnevern (Kap. 8, s. 177-198). Oslo: Cappelen Damm Akademisk. https://doi.org/10.23865/noasp.114.ch8

Lisens: CC-BY 4.o. 


\section{Innledning}

Samhandlingsreformen har medført at sykehjemmene har ansvar for de sykeste eldre med flere kroniske sykdommer og funksjonssvikt (Helseog omsorgsdepartementet, 2009). Dette har ført til oppgaver som krever mer spesialisert pleie og behandling, uten at kompetanse og ressurser er nok styrket i kommunene (Helse- og omsorgsdepartementet, 2016). Dermed opplever sykepleiere mer komplekse oppgaver, kompliserte medisinske prosedyrer og større krav til koordinasjon av beredskap og kvalitetssikring (Haukelien, Vike \& Vardheim, 2015). De sykeste eldre har høy risiko for akutt sykdom, og de er dermed mer sårbare når pasientsikkerheten svikter (Helsedirektoratet, u.å.). Pasientsikkerhet defineres av Verdens helseorganisasjon (WHO) (2009) som vern mot unødig skade som følge av helsetjenestens ytelser eller mangel på ytelser. Et mål for omsorgstjenesten i Norge er å bedre kvaliteten og pasientsikkerheten gjennom opplæring og kompetanseheving (Helse- og omsorgsdepartementet, 2012). Ifølge Ballangrud (2015) har helsepersonell som jobber i frontlinjen, mulighet til å forebygge uønskede hendelser, og dermed er deres kunnskaper, ferdigheter og holdninger avgjørende for å fremme en god pasientsikkerhetskultur. Flere studier fremhever simuleringsbasert teamtrening som et av de viktigste tiltakene for å kunne forbedre pasientsikkerheten og redusere antall uønskede hendelser (Deering et al., 2011; McGaghie, Issenberg, Petrusa \& Scalese, 2010). Andre studier dokumenterer også at teamtrening fører til bedre resultat for pasientene (Brazil, 2017; McGaghie, Issenberg, Barsuk \& Wayne, 2014) og en klar effekt på pasientoverlevelse (Ajmi et al., 2019).

Mens simulering ofte skjer i et simuleringssenter, foregår simulering in situ, «på stedet», på deltakerens daglige arbeidsplass, og søker å gjenskape omgivelser hvor pasientsituasjoner oppstår (Flatgård \& Berg, 2016). Simulering in situ kan bidra til utvikling og læring individuelt, i team og på avdelingsnivå samt kan avdekke og forbedre utfordringer i organisasjonen. Samtidig som det er utfordrende å måle effekten av simulering in situ, viser studier at kombinasjonen av læring og arbeidsmiljø har potensial til å bli et velegnet læringsverktøy for å vedlikeholde og videreutvikle kompetanse (Rosen, Hunt, Pronovost, Federowicz \& Weaver, 2012). Selv om simulering in situ har vist seg å være en god mulighet til 
kompetanseutvikling innen spesialisthelsetjenesten (Ajmi et al., 2019), har vi ikke klart å finne studier som beskriver hvordan metoden har blitt brukt på sykehjem.

Hensikten med denne studien er derfor å beskrive sykepleieres erfaringer med å delta i simulering in situ, og hvilke refleksjoner som oppstår rundt pasientsikkerhet i sykehjem. Hvilke hindre for pasientsikkerheten oppdager sykepleierne, og hvilke muligheter ser de for forbedring i egen praksis?

\section{Pasientsikkerhet}

I stortingsmelding nr. 10 oppgis pasientsikkerhet som en av flere dimensjoner av kvalitetsbegrepet, nemlig at tjenesten skal «være trygg og sikker» (Helse- og omsorgsdepartementet, 2012). Kvaliteten på tjenesten kan dermed relateres til grad av sikkerhetskultur. Det er en klar sammenheng mellom høy grad av sikkerhetskultur og lav forekomst av uønskede hendelser (Ulrich \& Kear, 2014). Pasientsikkerhetsarbeid handler derfor om å skape en kultur som er åpen for læring, og som har vilje til forbedring (Helse- og omsorgsdepartementet, 2015). En slik kultur bør utvide oppmerksomheten fra skader og feil knyttet til enkeltindivider, til å se nærmere på systemet hvor feil og skader oppstår. For å minske risikoen for å utsette pasienter for feil og skader må både struktur og prosesser som fremmer pasientsikkerhet, studeres systematisk. Denne endringen fra søkelys på enkeltindivider til systemtenkning er et fellestrekk for både kvalitet og pasientsikkerhet (Cappelen, 2015).

Omfanget av pasientskader i kommunehelsetjenesten er lite kjent, men fra 1. juli 2019 ble varslingsplikten for alvorlige hendelser utvidet til også å gjelde kommunehelsetjenesten (Helsetilsynet, 2020). I Norsk sykepleierforbund (NSF) sin spørreundersøkelse blant 2008 sykepleiere svarte 35 prosent at de det siste året hadde gjort en feil, eller en forglemmelse som potensielt kunne påført en pasientskade. Av 1255 sykepleierne svarte 13,5 prosent at de hadde mangelfull opplæring på prosedyrer eller oppgaver, og 12,7 prosent hadde ingen kollegaer å rådføre seg med (Helmers, 2019).

Det nasjonale pasientsikkerhetsprogrammet «I trygge hender 24-7» skal bidra til å redusere pasientskader og øke pasientsikkerheten i Norge 
(Helsedirektoratet, u.å.). Ett av målene med programmet er å forbedre pasientsikkerhetskulturen i helsetjenesten. Dette stiller også krav til at sykepleierutdanningen retter økt oppmerksomhet på sykepleieprofesjonens kjernekompetanse innen pasientsikkerhetsarbeid. En metode for $ø$ kt refleksjon rundt pasientsikkerhet i helsetjenesten kan for eksempel være simulering in situ.

\section{Simulering som pedagogisk metode}

Simulering som pedagogisk metode innen helsefag er aktiviteter som etterlikner et klinisk miljø hvor man kan trene prosedyrer, ta beslutninger og drive kritisk tenking ved hjelp av rollespill, video eller simulatorer (Struksnes, Hofmann \& Ødegården, 2015). «Fidelity» er et begrep som beskriver hvor stor grad av realisme eller «naturtrohet» simulatoren og selve simuleringen representerer (Struksnes et al., 2015). «Low fidelity» representerer virkeligheten i liten grad, og «high fidelity» representerer virkeligheten i stor grad. «Naturtrohet» refererer både til i hvor stor grad utstyret som brukes, kopierer virkeligheten, for eksempel en menneskeliknende dukke som både puster og kommuniserer, og til innhold og undervisningsaktivitet, uavhengig av utstyret (Husebø \& Rystedt, 2015). Det er en tendens til å tro at høyre grad av fidelity alltid er bedre, men ifølge Beaubien og Baker (2004) har ikke forskning klart å vise en sammenheng mellom graden av fidelity og effekten av trening. De viser til tre dimensjoner av fidelity - miljø, utstyr og psykologisk dimensjon alle i et gjensidig forhold til hverandre. Den psykologiske dimensjonen handler om i hvilken grad deltakerne oppfatter simuleringen som en troverdig erstatning for situasjonen som trenes. Psykologisk fidelity er viktigst $i$ teamtrening, i og med at hensikten med treningen vil falle bort dersom deltakerne ikke oppfører seg slik de ville ha gjort i virkeligheten (Beaubien \& Baker 2004).

Metoden er velegnet for å forbedre praktiske eller tekniske ferdigheter i komplekse pasientsituasjoner, for å øve på presis kommunikasjon under teamarbeid samt for å stimulere til kritisk refleksjon over egne og andres prestasjoner i den aktuelle situasjonen (Cant \& Cooper, 2017). Læring skjer gjennom samhandling, refleksjon og respons fra andre deltakere. 
I simuleringen brukes en tredelt pedagogisk modell: brifing, gjennomføring av simulering og debrifing (Struksnes et al., 2015). I brifingen, som skal bidra til trygghet, gjennomgår fasilitator (lærerveileder) læringsutbyttet, scenarioet og utstyret som benyttes i simuleringen, fordeler roller til dem som simulerer, og er observatører. I simulering in situ brukes det utstyret som finnes på den enkelte arbeidsplassen. Etter simuleringen brukes debrifing til refleksjon. Dette er en strukturert samtale som er tredelt: beskrivelsesfase, analysefase og anvendelsesfase. Med utgangspunkt i læringsutbyttet for simuleringen beskriver deltakerne hvordan de føler at de har løst utfordringer i scenarioet, og hva de gjorde. Deretter analyserer deltakerne hva som gikk bra, hva som kunne ha vært gjort bedre, og begrunner med teoretisk kunnskap. Fasilitator følger opp refleksjonen og trekker inn fagkunnskap. Deretter får observatørene komme med sine refleksjoner. I anvendelsesfasen avrunder fasilitator med å spørre deltakerne hva de har lært, og hvordan kunnskapen kan anvendes i andre situasjoner. Hensikten er å bidra til opplevelse av mestring og ny kunnskap (Struksnes et al., 2015). Debrifing er en viktig komponent for læring i simulering og anbefales alltid som en integrert del i simuleringsbasert læring (Levett-Jones \& Lapkin, 2014).

Våren 2017 deltok tolv sykepleiere og seks sykepleierstudenter på tredje studieår i simulering in situ på et sykehjem. Sykehjemmet har over hundre plasser, fordelt på enheter med ni pasienter per enhet. Simuleringen ble gjennomført i dagligstuen på sykehjemmet med en «Nursing Anne»dukke (simulatoren) som pasient med akutte brystsmerter og pusteproblemer. I forkant av simuleringen hadde sykepleierstudentene ansvar for å trene ferdigheter i hjerte-lunge-redning og repetere systematiske pasientobservasjoner sammen med sykepleierne. I selve simuleringen deltok sykepleierstudentene og sykepleierne sammen i sine daglige roller.

I denne studien presenteres sykepleiernes erfaringer. Sykepleierstudentenes erfaringer vil bli publisert i en annen artikkel.

\section{Metode}

Studien har en kvalitativ og induktiv tilnærming. Simuleringen ble gjennomført av første og andre forfatter, som også er lærerveiledere 
for sykepleierstudentene. Data er innsamlet gjennom to fokusgrupper med fem-seks sykepleiere per gruppe på et møterom på sykehjemmet i etterkant av simuleringen. Via fokusgruppe fremskaffes data gjennom samhandling i mindre grupper om et bestemt tema (Halkier, 2016). En fokusgruppe kan bidra til kreativitet og nytenkning og kan derfor bli en rik kilde for utvikling av nye strategier omkring pasientsikkerhet i sykehjem. Ved å engasjere deltakerne med ulike perspektiver i debatten kan fokusgruppe bidra til å forstå mangfoldet i hvordan deltakerne tenker om pasientsikkerhet. Mangfoldet kan derfor styrke de synspunktene som kommer frem i gruppen, ved at man får flere nyanser frem i debatten (Ritchie, 2014). En styrke ved dette kan være at samtalene i gruppene glir lett, fordi deltagerne er trygge på hverandre. Svakheten er at noen dominerer og ikke slipper andre til i diskusjonen (Halkier, 2016).

Elleve av de tolv forespurte sykepleiere som deltok i simulering sammen med sykepleierstudenter, samtykket til å delta i påfølgende fokusgruppe. Utvalget består av ansatte fra alle avdelinger, ti kvinner og en mann i alderen 23-60 år, med 1-25 års arbeidserfaring som sykepleiere.

Alle hadde fått teoretisk innføring i simulering som pedagogisk metode, repetisjon i bruken av systematisk pasientobservasjon og tiltak med ABCDE-algoritmen (airway, breathing, circulation, disability, exposure/environment), sikker muntlig kommunikasjon i henhold til ISBAR-prinsippet (identifikasjon, situasjon, bakgrunn, aktuelle vurderinger, råd) (Moi, Söderhamn, Marthinsen \& Flateland, 2019), informasjon om «casen» eller «scenarioet» (Struksnes et al., 2015) samt praktisk trening i hjerte-lunge-redning.

Tre sykepleiere hadde erfaring med simulering i øvingsrom, men ikke med simulering in situ. De øvrige hadde ingen erfaring med simulering. Hver sykepleier deltok i samme scenario to ganger, en gang som aktiv deltaker, og en gang i rollen som observatør. Scenarioet hadde en varighet på 15-20 minutter.

I fokusgruppene var tredjeforfatter moderator, og andreforfatter var bisitter og bisto med notater. Begge er lærerveiledere ved sykepleierutdanningen. Moderators rolle er å lytte og få deltakerne til å uttrykke sine erfaringer og diskutere sammen (Halkier, 2016). Moderator skal samtidig håndtere det sosiale samspillet i gruppen, uten å kontrollere det, 
og få deltakerne til å fortelle om egen forståelse og erfaring. Det ble brukt en intervjuguide med flere temaer vi ønsket å belyse. Samtidig ble deltakerne oppmuntret til å snakke fritt om sine erfaringer fra simuleringen. Åpningsspørsmålet var: «Kan dere fortelle om hva dere erfarte da dere simulerte?» Fokusgruppene varte i 60-110 minutter, ble tatt opp digitalt og deretter transkribert ordrett av en transkripsjonsassistent.

Det transkriberte materialet ble analysert $\mathrm{i}$ tråd med den kvalitative innholdsanalysen til Graneheim, Lindgren og Lundman (2017). Dette er en systematisk analyse av tekst der man ønsker å forstå hvordan informantene gir mening og innhold til et bestemt fenomen. Først ble teksten lest som helhet for å få et førsteinntrykk. Teksten ble systematisert og delt opp i meningsenheter, kondensert og kodet (tabell 1). Ved å gå frem og tilbake mellom hele teksten og meningsenheter ble likheter og ulikheter gruppert i fem subkategorier, deretter i to kategorier (tabell 2). Disse uttrykker det manifeste innholdet i teksten. En tekst kan tolkes på ulike måter og er avhengig av forskerens forforståelse (Graneheim et al., 2017). For å oppnå bevissthet og avstand til egen forforståelse er det en styrke at alle forfattere har vært involvert $\mathrm{i}$ alle deler av analyse- og tolkningsprosessen. Det er også en styrke at fjerdeforfatter ikke har kjennskap til simulering som metode eller deltok i selve simuleringen. Dette bidro til at fjerdeforfatter utfordret forforståelsen i analyseprosessen. Vi har diskutert og blitt enige om sortering av datamaterialet og den manifeste tolkningen av teksten.

Utvalget av deltakere vurderes å sikre både bredde og variasjon. Dette har bidratt med varierende perspektiver og rike beskrivelser av erfaringer. Samtidig er det en svakhet at noen deltakere var mer dominerende enn andre i diskusjonen, ettersom man slik kan ha mistet noen nyanser av erfaringene. Antall deltakere var få, men i tråd med anbefalinger for kvalitativ forskning, der hensikten er å oppnå et rikholdig materiale som fortsatt er mulig å håndtere i henhold til metodens hensikt (Sandelowski, 1995). Studien (50904) ble godkjent av NSD - Norsk senter for forskningsdata og gjennomført i samsvar med forskningsetiske retningslinjer (De nasjonale forskningsetiske komiteene, 2010).

Utsagn fra deltakere i fokusgruppe 1 presenteres som 1a, 1b, 1c og så videre, og fokusgruppe 2 presenteres som $2 \mathrm{a}, 2 \mathrm{~b}, 2 \mathrm{c}$ og så videre. 
Tabell 1 Eksempel på analysen

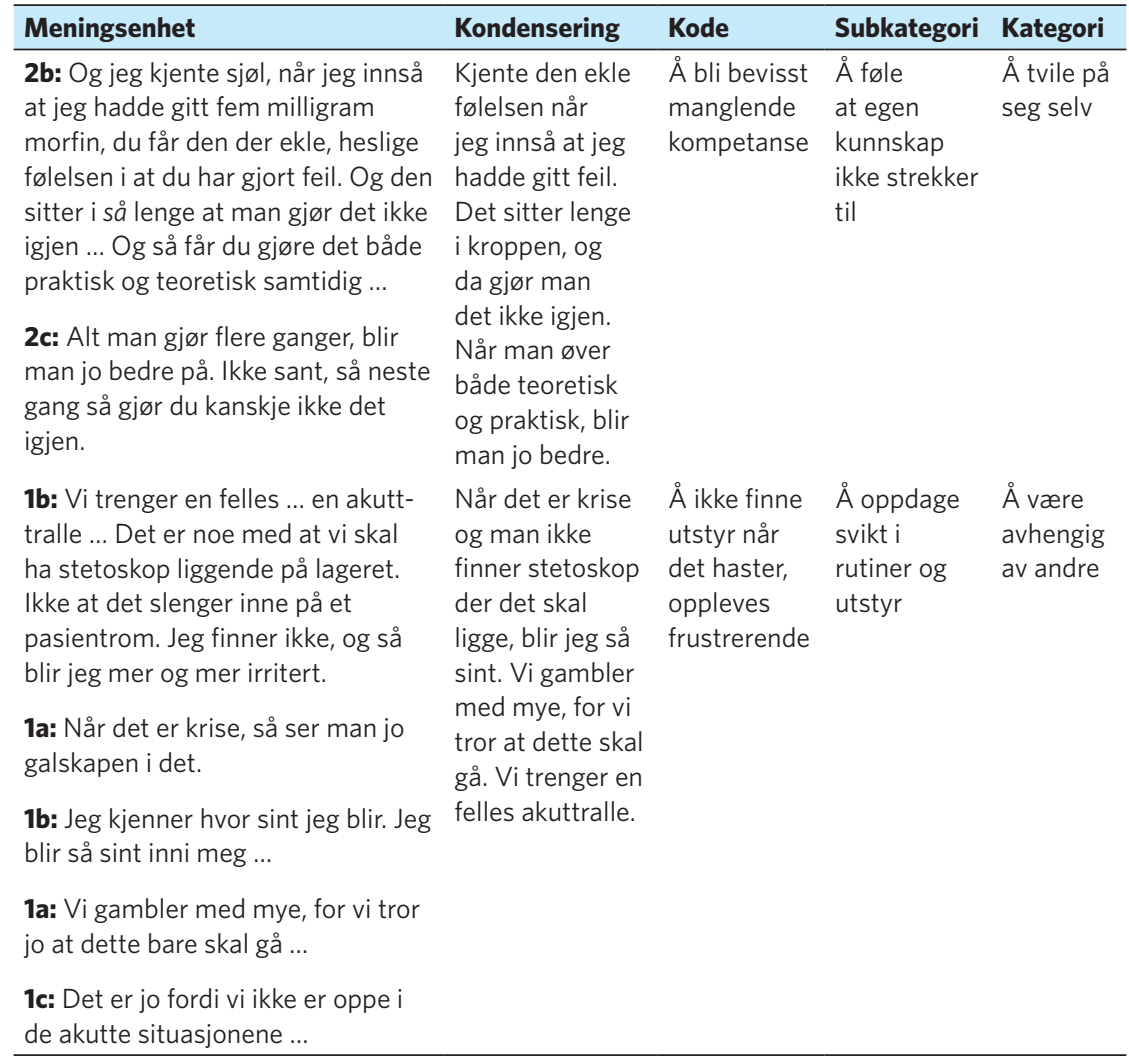

\section{Funn}

Analysen av teksten identifiserte to kategorier som beskriver sykepleiernes erfaringer: å tvile på seg selv og å vore avhengig av andre (tabell 2). Nedenfor presenteres disse kategoriene, og fem subkategorier presenteres med kursiv tekst.

Tabell 2 Kategorier og subkategorier

\begin{tabular}{|c|c|}
\hline Subkategori & Kategori \\
\hline \multicolumn{2}{|l|}{ Å ikke kjenne pasienten } \\
\hline Å føle at egen kunnskap ikke strekker til & Å tvile på seg selv \\
\hline \multicolumn{2}{|c|}{ Å oppdage betydningen av god kommunikasjon } \\
\hline Å oppdage svikt i teamarbeid & Å være avhengig av andre \\
\hline Å oppdage svikt i rutiner og utstyr & \\
\hline
\end{tabular}




\section{$\AA$ A tvile på seg selv}

Å skulle vurdere tilstanden til en ukjent pasient med pusteproblemer på dagligstuen, en ukjent arena, opplevdes utrygt og ikke som en dagligdags situasjon. Samtidig sammenlignes følelsen av utrygghet med å ha bakvakt på sykehjemmet, der sykepleierne ofte møter ukjente pasienter. A ikke kjenne pasienten er vanskelig, og man blir usikker og tviler på egen vurdering når man ikke vet om «dette her er vanlig, eller er det noe som er mer alvorlig?». Å stå alene og ikke ha en kollega å rådføre seg med bidrar til at man opplever usikkerhet i om man gjør en riktig beslutning, og derfor gruer man seg til bakvaktene på sykehjemmet. Under simuleringen var pasienten ukjent for alle, og man savnet derfor muligheten til å få faglige støtte av noen som kjenner pasienten.

Egen usikkerhet og tvil er lettere å håndtere når man får faglig støtte og bekreftelse på egen vurdering av noen som kjenner pasienten bedre. Under simuleringen måtte deltakerne ringe legen for å få legemiddelordinasjoner til en pasient de ikke kjente, som er noe de også gjør til daglig. Det ble utfordrende å gjennomføre, da legen (lærerveileder) ønsket flere opplysninger om pasientens tilstand enn man hadde kontroll over. Sykepleierne reflekterte over at de rutinene de har for palliative pasienter, med stående ordinasjoner, er en rutine som oppleves å gi trygghet og kontroll og dermed også økt pasientsikkerhet.

Det daglige arbeidet beskrives som rutinepreget og håndterbart, men simuleringen bidro til det å føle at egen kunnskap ikke strekker til. Det var lærerikt å oppdage egne svakheter, og man ble klar over at denne typen akuttsituasjoner krever fersk kunnskap for å kunne sikre pasienten. Sykepleierne diskuterte at både i simuleringen og til daglig kreves iblant en annen type kunnskap som man ikke har helt på plass. Det betyr at man gjør vurderinger man tviler på. Sykepleierne reflekterte over at sykepleierstudentene derimot hadde gode ferdigheter i ABCDE- og ISBAR-prinsippet, mens disse var for noen sykepleiere ukjente begreper. Sykepleier 1a sa: «Det var ikke noe vi brukte da vi gikk på skolen.»

1b: ... Du går mye i pleie og stell, og så plutselig så skjer det noe slik at du må kunne alt det her, så kan det gå et halvt år eller tre år, og du skal kunne det igjen. 
Å holde det ved like ... Selv om nå var den veldig grei den her ABCD-en, men likevel, å holde det ved like ...

Å oppdage at man gjorde feil i simuleringen, var ubehagelig og kjentes på kroppen. Samtidig oppdaget man betydningen av å få øve både teoretisk og praktisk for å vedlikeholde kompetansen.

2b: Og jeg kjente sjøl, når jeg innså at jeg hadde gitt fem milligram morfin, du får den der ekle, heslige følelsen i at du har gjort feil. Og den sitter i så lenge at man gjør det ikke igjen ... Og så får du gjøre det både praktisk og teoretisk samtidig ...

2c: Alt man gjør flere ganger, blir man jo bedre på. Ikke sant, så neste gang så gjør du kanskje ikke det igjen.

Å tvile på egen kunnskap bidro til følelsen av usikkerhet, og å delta i simulering føltes som om man skulle opp til en eksamen. Dette bidro med motivasjon til å lese teori om for eksempel hjertesykdom på forhånd. Man så også muligheten til å få mer kunnskap uten å skade pasienten.

\section{Å være avhengig av andre}

Under simuleringen følte sykepleierne avmakt da de oppdaget hvor ulikt de vurderte pasienten i situasjonen. Når det var vanskelig å kommunisere og komme til enighet med hverandre, klarte man heller ikke å komme frem til en god vurdering. Sykepleierne savnet faglige diskusjoner om blant annet pasientens symptomer, og de oppdaget betydningen av god kommunikasjon for å sikre god behandling. Sykepleierne sier at kommunikasjonen kan svikte av mange årsaker, og til daglig bidrar også manglende norskspråklige ferdigheter til at man ikke alltid forstår hverandre. Dermed tar man iblant sjanser når man har bakvakt, og håper at det går bra.

1a: Når man har bakvakt, så er det veldig mange assistenter som nesten ikke forstår hva du sier ... språket ... vi krysser fingrer og hva vi eier og har, og håper på det beste.

Selv om man oppdaget at man ikke klarte å kommunisere tydelig under simuleringen, og man erfarte at man tar sjanser, sier sykepleierne at de er opptatt av å formidle sitt budskap slik at andre skal forstå. Man føler seg 
ofte alene, og man er klar over at egen vurdering får stor betydning for pasientbehandlingen, og man reiser samtidig spørsmål om man har for stort ansvar, noe som i sin tur kan true kvalitetssikringen. Å føle seg alene og usikker er krevende, og mange ganger hadde man ønsket at legen selv var til stede for å kvalitetssikre sykepleierens vurdering.

2a: Legen må liksom bare stole på det vi sier. Og jeg tenker noen ganger så hadde det vært fint at de hadde fått sett dem [pasienter] i sine øyeblikk og kunne tatt ei vurdering. For det er en måte hvordan vi legger det frem ... og hvordan det blir tolka.

2c: Vi kan nok styre egentlig både tiltak og behandlinga veldig mye ... det forutsetter jo at vi har bra kontroll og er opplest og kjenner dem godt og hele den, tenker jeg, eller føler jeg.

2a: Ja. Jeg tenker kvalitetssikringa sånn sett er ganske elendig når det gjelder det.

Simuleringen bidro til at sykepleierne oppdaget svikt $i$ teamarbeidet da roller og arbeidsoppgaver skulle fordeles. Når man er vant til å være alene som sykepleier, er det lett å miste oversikt og kontroll når man plutselig skal samarbeide i team med andre sykepleiere. Å samarbeide med en «leder» ble vanskelig når man var uenig i den andres vurdering. Samtidig som man strevde med å stole på sykepleieren i lederrollen, var man nødt å gi slipp på tvilen for å konsentrere seg om å utføre oppgaver man hadde fătt delegert. Situasjonen førte til refleksjoner over hvordan man delegerer oppgaver i det daglige. For å kunne delegere må man ha kontroll på hvem som er på vakt, og på hva slags oppgaver man kan delegere. Å stå alene med ufaglærte oppleves ofte som et dilemma når man ikke vet om den andre forstår betydningen av for eksempel endringer hos pasienten, eller om vedkommende har kompetanse til å iverksette tiltak mens man selv finner frem utstyr eller ringer legen.

2e: Ikke alle er kjent med hvor de skal hente det du trenger. Det er litt vanskelig. Jeg vet hvor jeg skal hente alt jeg trenger, men jeg kan ikke forlate pasienten ... til en som kanskje ikke kan den jobben, hvordan de skal observere pasienten. ... Nå trenger jeg mer folk her, ikke sant. Så du har det der dilemmaet, «hva skal jeg gjøre?». 
2d: ... De kan ikke hjelpe deg med en del ting når det først oppstår ting. ... Det kan være litt tøft.

I tillegg vil man ikke få den faglige støtten man er avhengig av for å sikre riktig behandling av pasienten. Det betyr at selv når man har mulighet til å delegere oppgaver, utfører man ofte alle observasjoner og målinger selv for ikke å miste kontroll. Samtidig erfarer sykepleierne at en erfaren hjelpepleier på vakt, som kjenner pasienten, vil bidra med støtte i situasjonen, og dermed kan man gi slipp på noe av kontrollen.

$\AA ̊$ oppdage at man under simuleringen brukte tid for å springe og lete etter utstyr i stedet for å ivareta pasienten, opplevdes som en «fiasko». Selv om slike hendelser ikke skjer så ofte på sykehjemmet, var det å oppdage svikt $i$ rutiner og utstyr en "tankevekker». Sykepleierne uttrykker frustrasjon og sinne og viser fortvilelse over ikke å ha utstyr tilgjengelig på en fast plass. De sier videre at man bør ha «ting på stell», slik at man finner utstyret når det haster. Det betyr at man er avhengig av hverandre, og av at alle tar ansvar og legger ting på riktig plass. Man føler at man «gambler» med mange ting, og man ser behovet for å opprette en felles plass, en «akuttralle» der utstyr skal ligge klart, slik at det ikke går ut over pasientsikkerheten.

1b: Vi trenger en felles ... en akuttralle ... Det er noe med at vi skal ha stetoskop liggende på lageret. Ikke at det slenger inne på et pasientrom. Jeg finner ikke, og så blir jeg mer og mer irritert.

1a: Når det er krise, så ser man jo galskapen i det.

1b: Jeg kjenner hvor sint jeg blir. Jeg blir så sint inni meg ...

1a: Vi gambler med mye, for vi tror jo at dette bare skal gå ...

1c: Det er jo fordi vi ikke er oppe i de akutte situasjonene ...

Sykepleierne reflekterer over at vurdering og behandling av pasienten kan svikte fordi rutinene ikke er gode nok. I tillegg til å bruke tid til å finne utstyr, for eksempel «veneflonkurven», er det også usikkert om man kan stole på at blodprøveglassene i kurven er ubrukt, eller om man må finne nye på lageret.

Sykepleierne diskuterer at legemiddelhåndteringen i simuleringen var uforsvarlig, men at det ikke har vært rapportert om feil i legemiddelhåndteringen på sykehjemmet. Sykepleierne sier: 
1d: Vi er ofte alene ... Det er ikke rapportert om feil, at vi har gitt feil. Vi er veldig nøye når vi går der ... Det bruker som regel å gå greit ...

1a: Vi er best alene.

Selv om simuleringen oppleves stressende, må man sikre at legemiddelhåndteringen er utført korrekt. Sykepleierne er enig i at man er avhengig av andre, men det er vanskelig å sjekke hverandre i det daglige når man ikke er to sykepleiere på vakt. Noen mener at man også må skryte av seg selv, at man egentlig i det daglige er flink til å håndtere situasjoner som oppstår.

\section{Diskusjon}

\section{Å tvile på seg selv}

Hensikten med studien er å beskrive sykepleieres erfaringer med å delta i simulering in situ, og hvilke refleksjoner som oppstår rundt pasientsikkerhet i sykehjem. Å delta i simulering var en ny erfaring for de fleste, og det var første gang på egen arbeidsplass. Simuleringen opplevdes som en kontinuerlig pendling mellom følelsen av usikkerhet i selve simuleringen, men også i det daglige arbeidet. Sykepleierne erfarer tilstrekkelig kompetanse i det daglige rutinearbeidet, samtidig som simuleringen bevisstgjorde dem på en følelse av usikkerhet - på seg selv, men også i samarbeid med andre. Lite kjennskap til pasienten og manglende vurderingskompetanse - i selve simuleringen, men også i sykepleiernes hverdag - kan forstås som faktorer som bidrar til at sykepleierne føler seg alene og tviler på seg selv og dermed opplever et begrenset handlingsrom for klare å ivareta pasientsikkerheten.

Å simulere på egen arbeidsplass, in situ, med en dukke som kommuniserer og puster, med utstyr som brukes i det daglige, gir mulighet til å gjenskape virkeligheten (Flatgård \& Berg, 2016). Simulering er en erfaring som skal gjenskape virkeligheten for å utvikle ferdigheter og kritisk refleksjon. Selv om deltakerne ikke opplevde at simuleringen «speilet» deres hverdag fullt ut, viser funnene at sykepleierne oppdaget hindre for pasientsikkerheten, men også muligheter for å forbedre egen praksis. Vi tolker det slik at absolutt realisme, eller høy grad av «fidelity», i 
simulering ikke er en nødvendighet for læring. Ifølge McFaden (2020) vil overdreven oppmerksomhet på de fysiske omgivelsene og utstyret kunne overskygge deltakernes læringsutbytte, eller det vil kunne bidra til feilaktig undervisning og læring i erfaringen.

$\AA$ ikke kjenne pasienten oppleves som et hinder for pasientsikkerheten. Denne innsikten får sykepleierne under simulering in situ. Dette er også gjenkjennbart fra tidligere studier, som viser at manglende pasientopplysninger gjør det vanskelig å treffe riktig behandlingsvalg (Rolfsjord, Mdala \& Straand, 2019) og dermed truer pasientsikkerheten. Å bruke standardiserte vurderingsverktøy, for eksempel ABCDE for å identifisere tidlig endring hos pasienten og ISBAR for sikker overføring av informasjon, kan bidra til økt kvalitet i vurdering av pasientens tilstand og videre rapportering (Moi et al., 2019). Samtidig viser våre funn at sykepleierne føler at egen kunnskap ikke strekker til, og de er ikke komfortable med å bruke disse vurderingsverktøyene. Dette kan tyde på et behov for ytterligere undervisning og trening på området. Akutt syke eldre representerer spesielle utfordringer for sykepleiere, fordi de har mindre reservekapasitet og et annet symptombilde enn yngre. Ofte blir ikke eldre pasienter vurdert systematisk, slik at vage symptomer blir oversett og akutte situasjoner oppstår. Derfor anbefales det også å bruke NEWS («National Early Warning Score») som en rask, enkel triagemetode for å identifisere alvorlighetsgraden hos pasienten (Burch, Tarr \& Morroni, 2008). Simulering er nevnt som et tiltak i pasientsikkerhetsprogrammet «I trygge hender 24-7» (Helsedirektoratet, u.å.) for å trene på disse vurderingsverktøyene, og simulering kan bidra til økt kompetanse i å gjøre systematiske observasjoner og vurderinger i uforutsette pasientsituasjoner. Å stole på seg selv handler om å stole på egen kompetanse til å gjøre en vurdering. Troen på egen kompetanse, eller mestringstro, gjenspeiler i hvilken grad man har tillit til at man har de nødvendige forutsetningene for å møte ulike utfordringer (Wood \& Bandura, 1989). Funnene i vår studie er i tråd med en norsk studie innen kommunehelsetjenesten som viser at pleiepersonell har varierende kompetanse for å kunne sikre nødvendig omsorg og behandling av eldre pasienter (Bing-Jonsson, Hofoss, Kirkevold, Bjørk \& Foss, 2016). Som forventet innehar sykepleiere høyere kompetanse enn hjelpepleiere, helsefagarbeidere og assistenter på de fleste områder, 
men ikke på alle. Funnene fra studien indikerer at pleiepersonell som gruppe (sykepleiere, hjelpepleiere, helsefagarbeidere og assistenter) viser manglende grunnleggende sykepleiekompetanse innen observasjon, systematisk vurdering, iverksetting av sykepleietiltak, avanserte prosedyrer (for eksempel bruk av sentralt venekateter), dokumentasjon og samarbeid med medarbeidere når det er nødvendig (Bing-Jonsson et al., 2016).

\section{Å være avhengig av andre}

Simuleringen ble gjennomført i team med sykepleiere, der man var avhengig av andre for å sikre god behandling av pasienten. Selv om sykepleierne hadde ulike synspunkter på pasientens tilstand, benyttet de seg ikke av muligheten til å diskutere med sine kollegaer. Simuleringen bevisstgjorde dem således på betydningen av god kommunikasjon i en stresset situasjon, der samhandlingen kan bli truet. ISBAR som strukturert kommunikasjon kunne ha bidratt til bedre samhandling underveis. Kommunikasjon og samhandling er grunnleggende kjernekompetanse i teamarbeid, og sykepleierne erfarer hva det har å bety for pasientsikkerheten. En ny studie viser at studenter som brukte ISBAR i klinisk praksis, ble mer bevisst på sin egen kommunikasjonsstruktur. De følte seg også mer sikre på egen kompetanse og kommunikasjon, og de klarte raskere å få oversikt over pasientsituasjoner. Disse elementene førte til forbedret pasientsikkerhet (Moi et al., 2019).

Selv om de til daglig arbeider i team, oppdaget sykepleierne at teamarbeidet sviktet. Årsaken til manglende samarbeid var at de i hverdagen er vant å være alene som sykepleier på vakt, og de har sjelden andre sykepleiere å støtte seg til. En undersøkelse gjort av Norsk sykepleierforbund viser at mange sykepleiere ikke har kollegaer å rådføre seg med (Helmers, 2019), noe som oppleves som en utfordring for dem (Damsgaard, 2010). Selv om sykepleierne sier at de er vant til å jobbe alene, er det vanskelig å ha både mange vikarer og ufaglærte kollegaer i teamet. Når det i tillegg i hverdagen er mange ufaglærte som nesten ikke forstår hva man sier, blir sykepleierne usikre på hvordan de skal organisere arbeidet. For å utnytte ressursene best mulig er evnen og muligheten til å delegere en viktig faktor. Samtidig er det en trussel for pasientsikkerheten at sykepleierne opplever at de ikke 
stoler på andres kompetanse, og at de dermed ikke kan delegere oppgaver. I Norge utgjør ufaglært arbeidskraft, fremmedspråklige og vikarer en stor andel av bemanningen i sykehjem (Morland, 2019). Selv om sykepleierne ofte står alene med det sykepleiefaglige ansvaret, er teamarbeid viktig for å kunne sikre forsvarlige helsetjenester. Teamarbeid er en integrert del av dagens spesialiserte og komplekse helsetjenester, og effektivt teamarbeid er dermed kritisk for å sikre pasientsikkerhet (Husebø \& Rystedt, 2015). Sykepleiere har ansvar for sykepleietjenesten, både faglig på individnivå og organisatorisk på systemnivå. Dette er utfordrende, da ikke alle oppgaver kan delegeres videre (Orvik, 2015). Kartlegging gjort av norsk sykepleierforbund (NSF) viser at en av fem vakter ble bemannet av andre med lavere kompetanse eller forble ubemannet (Morland, 2019). Studien til Aiken et al. (2014) viser at økt sykepleiekompetanse på bachelornivå gir bedre mulighet til overlevelse for pasienten, og i lys av den økte kompleksiteten i sykehjem i dag, er dette funn som det er viktig å belyse.

Erfarne hjelpepleiere er viktige støttespillere i sykepleiernes hverdag. En viktig innvending til fremtidig øving med søkelys på teamtrening er dermed at både hjelpepleiere og assistenter deltar i simuleringen på sykehjemmet, og at treningen blir gjentatt og satt i system. For å bidra til økt kompetanse blant alle i pleiepersonalet, og for å få størst mulig utbytte av simulering, bør simuleringsbasert trening inkludere de teammedlemmene som samarbeider til daglig. Watters et al. (2015) har sammenlignet simuleringstrening i tverrprofesjonelle og enprofesjonelle team. Studien viser at det største læringsutbyttet kommer gjennom tverrprofesjonell simuleringstrening. En studie viser at simulering som inkluderer både sykepleiere og leger, fører til økt oppmerksomhet og bevissthet på effektiv kommunikasjon og dermed økt pasientsikkerhet (Meurling, Hedman, Sandahl, Felländer-Tsai \& Wallin, 2013).

I simuleringen ble sykepleierne bevisst på at legemiddelhåndteringen sviktet og truet pasientsikkerheten, til tross for at flere sykepleiere deltok. $\AA$ oppdage svikt i rutiner og utstyr førte til diskusjoner om ressursmangel som hinder for å kunne gjennomføre dobbeltsjekk og kvalitetssikre legemiddelhåndtering i hverdagen. Dette kan forstås som at rutiner ikke er godt nok forankret, eller som at deltakerne ikke klarte å leve seg inn i simuleringen og se situasjonen som realistisk. 
Tidspress og uforutsette avbrytelser er to sentrale årsaker til brudd på pasientsikkerheten ved legemiddelhåndtering (Holmström et al., 2012; Storli, Ingebrigtsen, Nakrem \& Elstad, 2016). Simuleringen bidro også til diskusjoner rundt rutiner for behovsmedisinering. Funnene viser at faste ordinasjoner til palliative pasienter gir trygghet for sykepleierne, samtidig som annen behovsmedisinering krever kontakt med legen for ordinasjon. Mange sykepleiere opplever det enklere og mer akseptert å gi behovsmedisin som er ordinert til den enkelte pasient (Andreassen, 2009). For å øke pasientsikkerheten rundt legemiddelhåndtering er det viktig med generelle skriftlige direktiver for behovsmedisinering. Tydelig informasjon vil klargjøre for sykepleierne når legen skal kontaktes ved eventuell terapisvikt (Andreassen, Halvorsen \& Granås, 2011). Simuleringsbasert undervisning kan også bidra til sikrere legemiddelhåndtering blant nyutdannede sykepleiere (Sears, Goldsworthy \& Goodman, 2010).

Under simulering vil ikke det å gjøre feil få konsekvenser for liv og helse. Likevel føles det ubehagelig å ha bidratt til feilmedisinering. Samtidig poengterer sykepleierne at det ikke er rapportert om feil med tanke på legemiddelhåndteringen på sykehjemmet. Det er uklart om man mener at det ikke er rapportert om avvik, om det faktisk ikke er gjort noen feil, eller om man ikke har hatt mot til å rapportere egne feil. Å begå alvorlige feil ved legemiddelhandtering vil påvirke sykepleiere personlig og profesjonelt (Schelbred \& Nord, 2007). Redsel for å bli uglesett av kollegaer og for å motta disiplinære reaksjoner fra ledelsen kan bidra til at man unnlater å melde fra. En slik holdning er i skarp kontrast til behovet for god rapporteringskultur, hvor uønskede hendelser danner utgangspunkt for kvalitetsforbedring i pleien. En lærende og rettferdig kultur bidrar til øt rapportering om feilmedisinering (Holmström et al., 2012; Schelbred \& Nord, 2007). Uten åpenhet er det ikke mulig å forebygge og lære av feil.

Den store oppdagelsen fra simuleringen var å oppdage svikt $i$ rutiner og utstyr. Oppbevaring og kvalitetssikring av utstyr var i mange tilfeller tilfeldig og ikke satt i system. Til daglig fungerer dette greit, men når noe uforutsett skjer, slik som i situasjonen i simuleringen, blir det tydelig hvor mye det betyr å ha system og rutiner for å redusere risikoen for skader og feil. Manglende akuttralle, veneflonkurver med manglende utstyr og uenighet om oppbevaring av medisinskteknisk utstyr kan få 
store konsekvenser ved akutte hendelser. Denne innsikten skapte frustrasjon, men samtidig motivasjon til å bidra med endringer i egen praksis for å forbedre rutiner og pasientsikkerheten på sykehjemmet. Våre funn er forenelig med tidligere forskning som viser at simulering in situ som metode kan bidra til å avdekke årsaker til uønskede hendelser og dermed bedre pasientsikkerheten (Naik \& Brien, 2013; Palaganas, Epps \& Raemer, 2014).

\section{Avslutning}

Denne studien viser at det å delta i simulering in situ på sykehjem bidro til at sykepleierne identifiserte flere hindre for pasientsikkerheten, både hos seg selv og i samarbeid med andre. Manglende kompetanse innen systematisk observasjon, manglende ferdigheter i bruken av systematisk vurderingsverktøy samt manglende samhandling og kommunikasjon i teamet bidro til usikkerhet i vurderingen av den ukjente pasienten $\mathrm{i}$ simuleringsscenarioet. Gjennom å delta i simulering in situ oppdaget sykepleierne samtidig muligheten til å kunne forbedre egne ferdigheter uten å utsette pasienten for skade. Å oppdage svikt i rutiner og utstyr skapte engasjement blant sykepleierne til å forbedre rutiner, noe som vil kunne bidra til å styrke pasientsikkerheten. Samtidig som det er utfordrende å måle effekten av simulering in situ, vil det å øve jevnlig for å vedlikeholde tekniske ferdigheter, kommunikasjon og teamarbeid kunne bidra til opplevelse av mestring og trygghet hos sykepleierne. $\AA$ bli bevisstgjort egne svakheter og svikt i rutiner kan belyse eget kompetansebehov samt inspirere til aktiv deltakelse i avdelingens pasientsikkerhetsarbeid. Dette kan også gi ledelsen et bilde på den samlede kompetansen ved arbeidsplassen, og i samarbeid med de ansatte kan det bidra aktivt til å fremme en felles kultur for pasientsikkerhetsarbeid på sykehjemmene. Sykehjemmene har i dag ansvar for de sykeste eldre, men samtidig er ikke kompetanse og ressurser nok styrket i kommunene. Simulering in situ har vist seg å være en god mulighet til kompetanseutvikling innen spesialisttjenesten, og derfor bør metoden tas i bruk i større grad, også i kommunehelsetjenesten på sykehjem, for å prøve å tette dette kompetansegapet. 
Fremover vil det være viktig å forske på hvilke typer simuleringsscenarioer som vil kunne bidra til økt pasientsikkerhet og gi best læringsutbytte for ansatte i sykehjem, og på hvorvidt bruken av simulering in situ vil kunne få betydning for å beholde og rekruttere sykepleiere til kommunehelsetjenesten.

\section{Referanser}

Aiken, L. H., Sloane, D. M., Bruyneel, L., Van Den Heede, K., Griffiths, P., Busse, R., Sermeus, W. (2014). Nurse staffing and education and hospital mortality in nine European countries: A retrospective observational study. The Lancet, 383(9931), 1824-1830. https://doi.org/10.1016/So140-6736(13)62631-8

Ajmi, S. C., Advani, R., Fjetland, L., Kurz, K. D., Lindner, T., Qvindesland, S. A., Kurz, M. (2019). Reducing door-to-needle times in stroke thrombolysis to 13 min through protocol revision and simulation training: A quality improvement project in a Norwegian stroke centre. BMJ Quality and Safety, 28(11), 939-948. https://doi.org/10.1136/bmjqs-2018-0o9117

Andreassen, L. M. (2009). Helsepersonells erfaringar, tankar og haldningar til behovsmedisinering i sjukeheimar (Masteroppgave). Universitet i Bergen, Bergen.

Andreassen, L. M., Halvorsen, K. H. \& Granås, A. G. (2011). P.r.n. medication in nursing homes - varying content, formulation and quality in administration guidelines. Sykepleien forskning, 6(1), 46-52.

Ballangrud, R. (2015). Pasientsikkerhet og simulering. I S. Struksnes, B. Hofmann \& T. Ødegården (Red.), Pasientsimulering i helsefag - en praktisk innfaring (s. 62-70). Oslo: Gyldendal Akademisk.

Beaubien, J. M. \& Baker, D. P. (2004). The use of simulation for training teamwork skills in health care: How low can you go? BMJ Quality and Safety, 13, i51-i56.

Bing-Jonsson, P. C., Hofoss, D., Kirkevold, M., Bjørk, I. T. \& Foss, C. (2016). Sufficient competence in community elderly care? Results from a competence measurement of nursing staff. BMC Nursing, 15, 5. https://doi.org/10.1186/s12912-016-0124-Z

Brazil, V. (2017). Translational simulation: Not 'where?' but why?' A functional view of in situ simulation. Advances in Simulation, 2(1). https://doi.org/10.1186/s41077017-0052-3

Burch, V. C., Tarr, G. \& Morroni, C. (2008). Modified early warning score predicts the need for hospital admission and inhospital mortality. Emergency Medicine Journal, (10), 674-678.

Cant, R. P. \& Cooper, S. J. (2017). Use of simulation-based learning in undergraduate nurse education: An umbrella systematic review. Nurse Education Today, 49, 63-71. https://doi.org/10.1016/j.nedt.2016.11.015 
Cappelen, K. (2015). Pasientsikkerhetskultur i sykehjem. I K. Aase (Red.), Pasientsikkerhet: teori og praksis (2. utg., s. 87-97). Oslo: Universitetsforlaget. Damsgaard, H. L. (2010). Den profesjonelle sykepleier. Oslo: Cappelen Damm Akademisk.

De nasjonale forskningsetiske komiteene. (2010). Veiledning for forskningsetisk og vitenskapelig vurdering av kvalitative forskningsprosjekt innen medisin og helsefag. (9788276820584). Oslo: De nasjonale forskningsetiske komiteene. Hentet fra https://www.forskningsetikk.no/retningslinjer/med-helse/vurdering-avkvalitative-forskningsprosjekt-innen-medisin-og-helsefag/

Deering, S., Rosen, M. A., Ludi, V., Munroe, M., Pocrnich, A., Laky, C. \& Napolitano, P. G. (2011). On the front lines of patient safety: Implementation and evaluation of team training in Iraq. Joint Commision Journal on Quality and Patient Safety, 37(8), 350-356.

Flatgård, I. \& Berg, G. V. (2016). Simulatortrening in situ, lek eller læring? - En intervjuundersøkelse av hvilke erfaringer sykepleiere har med debrifingsfasen i full-skala simulatortrening gjennomført ved egen arbeidsplass. Nordisk sygeplejeforskning, 6(3). 216-232. Hentet fra https://www.idunn.no/nsf/2016/o3/ simulatortrening_in_situ_lekeller_laering_-_en_intervjuun

Graneheim, U. H., Lindgren, B.-M. \& Lundman, B. (2017). Methodological challenges in qualitative content analysis: A discussion paper. Nurse Education Today, 56, 29-34. https://doi.org/10.1016/j.nedt.2017.06.002

Halkier, B. (2016). Fokusgrupper (3. utg.). Frederiksberg: Samfundslitteratur.

Haukelien, H., Vike, H. \& Vardheim, I. (2015). Samhandlingsreformens konsekvenser $i$ de kommunale helse og omsorgstjenestene: Sykepleieres erfaringer (TF-rapport nr. 362). Hentet fra http://www.tmforsk.no/publikasjoner/start.asp? merket=5

Helmers, A.-K. B. (2019, 24. oktober). Tre av ti sykepleiere frykter ukentlig å gjøre feil som skader pasienten. Sykepleien. Hentet fra https://sykepleien.no/2019/10/ tre-av-ti-sykepleiere-frykter-ukentlig-gjore-feil-som-skader-pasienten

Helsedirektoratet. (u.å.). Pasientsikkerhetsprogrammet I trygge hender 24-7. Hentet 15. januar 2020 fra https://pasientsikkerhetsprogrammet.no/

Helse- og omsorgsdepartementet. (2009). Samhandlingsreformen - rett behandling på rett sted - til rett tid (St.meld. 47 (2008-2009)). Hentet fra https://www. regjeringen.no

Helse- og omsorgsdepartementet. (2012). God kvalitet - trygge tjenester: Kvalitet og pasientsikkerhet $i$ helse- og omsorgstjenesten (Meld. St. 10 (2012-2013)). Hentet fra https://www.regjeringen.no

Helse- og omsorgsdepartementet. (2015). Nasjonal helse- og sykehusplan (2016-2019) (Meld. St. 11 (2015-2016)). Hentet fra https://www.regjeringen.no

Helse- og omsorgsdepartementet. (2016). Riksrevisjonens undersøkelse av ressursutnyttelse og kvalitet $i$ helsetjenesten etter innføringen av 
samhandlingsreformen (Rapport, dokument 3:5 (2015-2016)). Hentet fra https://www.riksrevisjonen.no/globalassets/rapporter/no-2015-2016/ samhandlingsreformen.pdf

Helsetilsynet. (2020). Kommunale helse- og omsorgstjenester. Hentet 22. august $2020 \mathrm{fra} \mathrm{https://www.helsetilsynet.no/tilsyn/varsel-om-alvorlige-hendelser/}$ kommunale-helse-og-omsorgstjenester/

Holmström, A.-R., Airaksinen, M., Weiss, M., Laaksonen, R., Wuliji, T. \& Chan, X. H. (2012). National and local medication error reporting systems: A survey of practices in 16 countries. Journal of Patient Safety, 5(4), 165-176.

Husebø, S. E. \& Rystedt, H. (2015). Simulering innen helsefag. I K. Aase (Red.), Pasientsikkerhet: Teori og praksis (2. utg., s. 169-186). Oslo: Universitetsforlaget.

Levett-Jones, T. \& Lapkin, S. (2014). A systematic review of the effectiveness of simulation debriefing in health professional education. Nurse Education Today, $34(6)$, e $58-\mathrm{e} 63$.

McFaden, C. (2020). Simulation realism, contextual fidelity, and unintended lessons. Nurse Education Today, 85, 104307. https://doi.org10.1016/j.nedt.2019.104307

McGaghie, W. C., Issenberg, S. B., Barsuk, J. H. \& Wayne, D. B. (2014). A critical review of simulation-based mastery learning with translational outcomes. Medical Education, 48(4), 375-385. https://doi.org/10.1111/medu.12391

McGaghie, W. C., Issenberg, S. B., Petrusa, E. R. \& Scalese, R. J. (2010). A critical review of simulation-based medical education research: 2003-2009. Medical Education, 44(1), 50-63. https://doi.org/10.1111/j.1365-2923.2009.03547.x

Meurling, L., Hedman, L., Sandahl, C., Felländer-Tsai, L. \& Wallin, C.-J. (2013). Systematic simulation-based team training in a Swedish intensive care unit: A diverse response among critical care professions. BMJ Quality and Safety, 22(6), 485-494.

Moi, E. B., Söderhamn, U., Marthinsen, G. N. \& Flateland, S. M. (2019). Verktøyet ISBAR fører til bevisst og strukturert kommunikasjon for helsepersonell. Sykepleien forskning, 14(74699), e-74699.

Morland, E. (2019, 1. september). Nesten 1 av 5 vakter bemannet av andre enn sykepleiere - eller ikke i det hele tatt. Sykepleien. Hentet fra https://sykepleien. no/2019/o9/nesten-1-av-5-vakter-bemannet-av-andre-enn-sykepleiere-eller-ikkei-det-hele-tatt

Naik, V. N. \& Brien, S. E. (2013). Review article: Simulation: A means to address and improve patient safety. Can J Anaesth, 6o(2), 192-200. https://doi.org/10.1007/ s12630-012-986o-Z

Orvik, A. (2015). Organisatorisk kompetanse: Innføring i profesjonskunnskap og klinisk ledelse (2. utg.). Oslo: Cappelen Damm Akademisk.

Palaganas, J. C., Epps, C. \& Raemer, D. B. (2014). A history of simulation-enhanced interprofessional education. J Interprof Care, 28(2), 110-115. https://doi.org/10.310 9/13561820.2013.869198 
Ritchie, J. (2014). Qualitative research practice: A guide for social science students and researchers (2. utg.). London: SAGE.

Rolfsjord, I., Mdala, I. \& Straand, J. (2019). Sykebesøk på sykehjem: Får vaktlegen nok pasientinformasjon? Sykepleien forskning, 14(75498), e75498.

Rosen, M. A., Hunt, E. A., Pronovost, P. J., Federowicz, M. A. \& Weaver, S. J. (2012). In situ simulation in continuing education for the health care professions: A systematic review. Journal of Continuing Education in the Health Professions, 32(4), 243-254. https://doi.org/10.1002/chp.21152

Sandelowski, M. (1995). Sample size in qualitative research. Research in Nursing and Health, 18(2), 179-183.

Schelbred, A. B. \& Nord, R. (2007). Nurses' experiences of drug administration errors. Journal of Advanced Nursing, 6o(3), 317-324. https://doi.org/10.1111/j.13652648.2007.04437.x

Sears, K., Goldsworthy, S. \& Goodman, W. M. (2010). The relationship between simulation in nursing education and medication safety. Journal of Nursing Education, 49(1), 52-55. https://doi.org/10.3928/01484834-20090918-12

Storli, M., Ingebrigtsen, O., Nakrem, S. \& Elstad, T. A. (2016). Sikkerhetstiltak for legemidler i sykehjem. Sykepleien forskning, 11. https://doi.org//10.4220/ Sykepleienf.2016.59801

Struksnes, S., Hofmann, B. \& Ødegården, T. (2015). Pasientsimulering i helsefag - en praktisk innføring. Oslo: Gyldendal Akademisk.

Ulrich, B. \& Kear, T. (2014). Patient safety and patient safety culture: Foundations of excellent health care delivery.(Continuing Nursing Education)(Report). Nephrology Nursing Journal, 41(5), 447-456.

Watters, C., Reedy, G., Ross, A., Morgan, N. J., Handslip, R. \& Jaye, P. (2015). Does interprofessional simulation increase self-efficacy: A comparative study. $B M J$ Open, 5(1), eoo5472.

Verdens helseorganisasjon (WHO). (2009). Human factors in patient safety. Review of topics and tools (Rapport). Hentet fra http://www.who.int/patientsafety/ research/methods_measures/human_factors/human_factors_review.pdf

Wood, R. \& Bandura, A. (1989). Social cognitive theory of organizational management. Academy of Management Review, 14(3), 361-384. 


\title{
Muligheter og begrensninger i sykepleierens handlingsrom når sykehjemspasientens sykdomstilstand forverrer seg
}

\author{
Synnøve Vestly \\ UiT Norges arktiske universitet
}

\section{Linda M. Løvdal}

Gratangsheimen, tidligere ansatt ved UiT Norges arktiske universitet

\begin{abstract}
The purpose of this chapter is to highlight the experiences of nurses working in nursing homes when it comes to detecting changes in a patient's condition at an early stage, so that treatment can be initiated as early as possible. How do nurses experience their sphere of action, their opportunities and their limitations to detect changes at the earliest stage possible?

Studies show that nurses experience this sphere of action as very limited. These limitations show most clearly when there is only one nurse on duty. In this situation, keeping track of all patients and their needs is particularly demanding and difficult, especially if other employees are untrained. With one exception, all informants feel that it is their responsibility if something goes wrong, and several say that it gives them a bad conscience to know that patients have suffered unnecessarily on their guard.

The informants indicate that their working lives have changed significantly after the introduction of the coordination reform.

The scope of both academic and organizational tasks has increased. The patients are sicker, which means that nurses are given more as well as more complicated and time-consuming tasks that only nurses have the competence to perform. All informants agree that this is both positive and negative. It is positive because the assignments are more varied, interesting and relevant to their specific professional competence. It is negative partly because not enough positions have been created
\end{abstract}

Sitering av denne artikkelen: Vestly, S. \& Løvdal, L. M. (2020). Muligheter og begrensninger i sykepleierens handlingsrom når sykehjemspasientens sykdomstilstand forverrer seg. I B. L. L. Kassah, H. Nordahl-Pedersen \& W.-A. Tingvoll (Red.), Handlingsrom for profesjonalisert velferd: Kommunale tjenester for helse, omsorg og barnevern (Kap. 9, s. 199-219). Oslo: Cappelen Damm Akademisk. https:// doi.org/10.23865/noasp.114.ch9

Lisens: CC-BY 4.o. 
relative to the increased workload and partly because nurses have a greater responsibility, especially when there is only one nurse on duty. This happens relatively often due to high levels of sick leave and vacant positions. Several of the informants say that a redistribution of work tasks between the various occupational groups could help to expand their sphere of action in order to give them more time to attend to their specific tasks.

Keywords: academic responsibility, competence, nursing in nursing homes, deteriorating condition, responsibility, division of tasks

\section{Innledning}

Hensikten med denne studien er å løfte fram erfaringer sykepleiere som jobber i sykehjem gjør seg når det skjer endringer som tilsier forverring av pasientens tilstand. Hvordan opplever sykepleiere sitt handlingsrom for å kunne oppdage forverring i pasientens tilstand på et tidlig stadium i sykdomsutviklingen? Med handlingsrom forstås muligheter for å gjøre valg i rommet mellom begrensninger og krav (Stewart, 1982, 1989). Krav er juridiske rammer i form av lover, forskrifter, yrkesetikk, institusjonens målsettinger og stillingsbeskrivelser - altså hva som defineres som grunnlag for forsvarlig tjenestetilbud. Forventninger fra omgivelsene og fra sykepleieren selv kan også defineres som krav. Begrensningene kan være økonomiske rammer, noe som kan gi seg utslag i lav bemanning og i hvilken kompetanse som til enhver tid er tilgjengelig for å oppfylle kravene som er satt til forsvarlighet (Stewart, 1982, 1989).

Det er stor mangel på sykepleiere i Norge i dag, og prognosene tilsier at mangelen vil øke i tiden framover. I 2018 var mangelen på sykepleiere 4550, og mangelen på spesialsykepleiere var 1350 (Kolstø \& Sørbø, 2018, s. 8). I 2035 vil mangelen være på 28000 sykepleiere, og denne mangelen vil være selvforsterkende (Gautun, Øien \& Bratt, 2016, s. 37). Kommunene har ikke greid å følge opp kravet om tilstrekkelig kvalifisert bemanning (Mæhre, 2017). Ved siden av stort behov for sykepleiere i kommende år vil også behovet for helsefagarbeidere i den kommunale helse- og omsorgssektoren være økende. I 2014 var cirka 25 prosent av årsverkene som var knyttet til kommunale helse- og omsorgstjenester, uten helse- og sosialfaglig utdanning, altså ufaglærte (Helse- og omsorgsdepartementet, 2015, s. 73), og denne prosentandelen er økende. Med en økende prosentandel 
ufaglærte på sykehjemmene vil samlet kompetanse bli lavere, og sykepleiernes handlingsrom vil bli innskrenket.

Etter at samhandlingsreformen (Helse- og omsorgsdepartementet, 2009) ble iverksatt i 2012, har sykehjemmene fått overført pasienter fra spesialisthelsetjenesten som skrives ut som ferdigbehandlet. Dette er pasienter som tidligere lå inne på sykehuset for pleie og observasjoner, og som nå skal observeres og følges opp i sykehjem. Haug (2012) sier i en kommentar i Tidsskrift for Den norske legeforening at «ved innføringen av samhandlingsreformen har 'ferdigbehandlet' gått fra å være et medisinsk til å bli et økonomisk spørsmål». Etter gjennomføring av samhandlingsreformen har de faglige kravene til sykepleierne i kommunehelsetjenesten økt, fordi pasienter innlagt i sykehjem er sykere (Mæhre, 2017).

Et av formålene i helse- og omsorgstjenesteloven (2011, kap. 1, § 1-1) er å sikre kvalitet og likeverd i tjenestetilbudet til kommunens innbyggere. I helsepersonelloven (1999, kap. 2, \$ 4-5) heter det at helsepersonell skal utføre sitt arbeid i tråd med det forsvarlighetskravet som er tillagt deres profesjon. Videre står det at arbeidsoppgaver kan overlates til annet personell eller medhjelper hvis oppgavens art tilsier at dette er forsvarlig.

Forsvarlighetskravet er en rettslig standard forankret i fagkunnskap, faglige retningslinjer og allmenngyldige etiske normer. Kravet viser til normer som beskriver hvordan tjenestene bør være. Normene kan betegnes som god praksis, og de danner også utgangspunkt for å fastlegge grensen mot det uforsvarlige. Mellom det som betegnes som god praksis og forsvarlighetskravets nedre grense vil det være rom for skjønnsutøvelse. Det er kommunens ansvar å planlegge og iverksette tiltak som er nødvendig for å sikre at tjenestene som ytes, alltid er forsvarlige (NOU 2018: 16).

Norsk sykepleierforbund (NSF) har definert grensene for faglig forsvarlig praksis. Fra en lang liste henter vi tre punkter som er særlig aktuelle i denne sammenhengen (Norsk sykepleierforbund, 2018, s. 21):

- Pasienten blir ikke observert på et tilstrekkelig faglig grunnlag.

- Pasienten får komplikasjoner og tilleggslidelser fordi tegn på endret sykdomssituasjon ikke fanges opp eller nødvendige tiltak iverksettes i rett tid. 
- Pasienten får ikke tilfredsstillende smerte-/symptomlindring på grunn av tidspress og/eller manglende kompetanse.

Det er i dette kompliserte bildet sykepleieren skal gjøre sine handlingsvalg. Sykepleieren har en sentral funksjon når det gjelder organisering, prioriteringer, ansvar, kvalitet og forsvarlig pleie. Disse oppgavene er knyttet til direkte pasientkontakt, men også til organisering av annet personell, prioritering og fordeling av oppgaver, dokumentasjon og overordnet ansvar for pasientgrupper og hele avdelinger. Mot denne bakgrunnen er vårt forskningsspørsmål følgende: Hvordan opplever sykepleierne sitt handlingsrom når det gjelder å kunne oppdage forverring i pasientens tilstand på et tidlig stadium i sykdomsutviklingen?

\section{Tidligere forskning}

Flere studier gjort på sykehus konkluderer med at mangel på kompetanse, manglende (eller mangelfull) dokumentasjon, svikt i samarbeid og i kommunikasjon, er de vanligste årsakene til at det blir gjort feil i pasientomsorgen. Feilene dreier seg om alt fra feilmedisinering til fall, mangelfull observasjon og sent eller manglende utførte tiltak (Andersson, Frank, Willman, Sandman \& Hansebo, 2018; Bragadóttir \& Kalisch, 2018; Kalisch $\&$ Xie, 2014).

I en studie gjort blant leger og sykepleiere kommer det fram at det forutsetter faglig dyktige sykepleiere, helst med spesialutdanning innen geriatri, kreftsykepleie og palliasjon, å gi pasienter i sykehjem forsvarlig behandling og god pleie og omsorg (Dreyer, 2017, s. 182-183).

Hvis kompetansen i sykehjemmene ikke er tilstrekkelig til å gi pasientene forsvarlig pleie, bør pasientene behandles i sykehus. De fleste innleggelser av pasienter fra sykehjem til sykehus kunne vært unngått. Likevel ses det at pasienter som innlegges fra sykehjem til sykehus, ofte får komplikasjoner. Det viser seg at dette er noe som kan unngås hvis behandlingen kommer i gang på sykehjemmet før pasientens tilstand er blitt så alvorlig at sykehusinnleggelse ikke kan unngås. Men det krever forbedring av kompetansen til ansatte i sykehjemmet, slik at sykdomsutviklingen kan oppdages på et tidlig stadium 
(Briggs, Coughlan, Collins, O’Neill \& Kennely, 2013; Dreyer, 2017, S. 182-183).

I en studie gjort i en forsterket sykehjemsavdeling forteller sykepleierne at de ofte opplever å måtte bære et stort ansvar alene når de er på vakt. Dette legger stort press på den enkelte sykepleieren når hun må prioritere hvem som først skal få hjelp av henne, samtidig som hun vet at flere trenger hennes fagkompetanse like mye i samme øyeblikk (Mæhre, 2017).

Pasienter som etter gjennomføringen av samhandlingsreformen overflyttes fra sykehus til sykehjem, er eldre, sykere og har høyere dødelighet, noe som har medført større pasientgjennomstrømning enn før reformen ble innført. Det er grunn til å anta at dette har konsekvenser for økt kompetanse og bemanning i sykehjemmene (Bruvik, Drageset \& Abrahamsen, 2017). En landsomfattende evaluering av samhandlingsreformen viser at kommunene ikke har vært tilstrekkelig forberedt på konsekvensene ved innføring av reformen. Det skjedde ingen opptrapping med tanke på bemanning og kompetansebehov. Sykepleierne får flere og mer spesialiserte oppgaver, noe som resulterer i en forskyvning av oppgaver sykepleierne har tatt seg av tidligere, til helsefagarbeidere og ufaglærte. Eldre mennesker med mindre spesialiserte behov, men som likevel har flere og sammensatte diagnoser, blir nedprioritert. Dette resulterer ofte i at tilstander utvikler seg i negativ retning fordi sykepleierne ikke har tid til å ha tilsyn med pasientene selv (Haukelien, Vike \& Vardheim, 2015).

Det er gjennomført studier for å kartlegge tilgjengelighet av fagkompetanse i kommunal helse- og omsorgstjeneste ut fra de kravene og forventningene myndighetene setter til disse tjenestene. Det forventes fagkompetanse innenfor områdene tidlig intervensjon, akutt hjelp, behandling og pleie og omsorg. I de ni kommunene der studien ble gjennomført, viser resultatet mangler på følgende kliniske områder innenfor sykepleiefaget: relevante observasjoner, gjenkjenning av sykdomsforverring, iverksetting av rett sykepleietiltak til riktig tid, utførelse av prosedyrer og grundig dokumentasjon av sykepleie (Bing-Jonsson, Hofoss, Kirkevold, Bjørk \& Foss, 2016; Bing-Jonsson, 2016; Bing-Jonsson, Foss \& Bjørk, 2019).

Aiken og hennes medarbeidere (Aiken et al., 2011; Aiken, Clarke, Cheung, Sloane \& Silber, 2003; Aiken et al., 2014) har gjort flere studier 
i både USA og Europa hvor de har undersøkt sykepleiertettheten opp mot dødelighet hos pasienter i løpet av de første tretti døgn etter kirurgi. Både de amerikanske og de europeiske studiene viste reduksjon i dødeligheten når sykepleiertettheten økte. Dette er kanskje ikke direkte sammenlignbart med norske sykehjem, men med tanke på sykeligheten blant sykehjempasientene vil det meget godt kunne være tendenser i samme retning.

En kartlegging foretatt i sykehjem og hjemmesykepleien i 18 norske kommuner, viser at det er nærmere en firedel færre sykepleiere på jobb enn planlagt. Fraværet skyldes både vakante stillinger og sykefravær. Ved innleie er det oftest ufaglært personell som benyttes for å dekke fravær av sykepleiere. Det er derfor ikke uvanlig at det er bare én sykepleier på vakt med ansvar for et stort antall pasienter. Dette er bekymringsfullt av flere grunner, blant annet fordi pasientene er sykere og har omfattende pleieog omsorgsbehov når de overføres fra sykehus til sykehjem (ECON, 2009; Holmeide \& Eimot, 2010).

Bergland, Vibe og Martinussen (2010) fant at en av forutsetningene for at sykepleiere skulle ønske å jobbe i sykehjem, var at deres oppgave- og ansvarsområde var tydeligere. I sin studie fant Allen (2019) at sykepleiere er sentrale i samtlige aktiviteter som foregår i avdelingen. Gjennom organisering av egen og andre faggruppers aktiviteter samordner og formidler sykepleier viktig og nødvendig informasjon som angår pasientene, videre til annet personell på en måte som er tilpasset deres profesjon og faglige nivå. Allen (2019) betegner dette som «sykepleierens usynlige arbeid». I tillegg deltar sykepleieren selv i aktiviteter på alle nivåer. Slik fremstår sykepleieren som selve «navet» $\mathrm{i}$ avdelingen (Allen, 2019).

\section{Studiens teoretiske ramme}

Kompetansebegrepet finner vi ofte omtalt i offentlige utredninger som omhandler den kommunal helse- og omsorgssektoren. I samhandlingsreformen kan vi lese følgende: «Skal denne reformen lykkes forutsettes det at det må arbeides med helsepersonellets kompetanse i sektoren» (Helseog omsorgsdepartementet, 2009, s. 125). Kompetanse stammer fra latin, competentia, og betyr sammentreff eller skikkethet. Å være kompetent 
innebærer at man har de nødvendige kvalifikasjonene som skal til for å inneha en stilling, ivareta bestemte oppgaver eller treffe en beslutning. Profesjonell kompetanse betyr å inneha spesifikke kvalifikasjoner som kreves i et bestemt yrke (Skau, 2017, s. 57).

Skau (2017) deler kompetanse inn i tre aspekter: teoretisk kunnskap, yrkesspesifikke ferdigheter og personlig kompetanse. Teoretisk kunnskap er kunnskap som er nødvendig for å romme et fag, og som har relevans for utøvelse av yrket. Kunnskap om faglige begreper, teorier og modeller er også deler av denne kunnskapen, likeledes kunnskap om lover og regler som regulerer fagområdet. De yrkesspesifikke ferdighetene omfatter håndverket - de profesjonsspesifikke praktiske ferdighetene som brukes i utøvelsen av yrket. For at praktiske ferdigheter skal kunne utføres på en trygg og sikker måte, må de være forankret i fagspesifikk teori. Det tredje aspektet i kompetansebegrepet er den personlige kompetansen. Denne kunnskapsformen er ikke yrkesspesifikk, men anvendes i utøvelsen av yrket. Personlig kompetanse er en kombinasjon av menneskelige kvaliteter, egenskaper, holdninger og ferdigheter (Skau, 2017). En kompetent sykepleier kombinerer teoretisk kunnskap, yrkesspesifikke ferdigheter og personlig kompetanse i sin fagutøvelse. Orvik (2015) skriver om den doble kompetansen, som utgjøres av den kliniske kompetansen og den organisatoriske kompetansen. Sykepleiere må være dyktige klinikere, men må også ha kompetanse i hvordan kliniske virksomheter er oppbygd og fungerer, og de må ha kompetanse i å organisere eget og andres arbeid. Den kliniske og den organisatoriske kompetansen er således gjensidig avhengig og utfyllende. Organisatoriske rammer og prosesser rundt pasientarbeidet er en del av faginnholdet i profesjonsutøvelsen. Dobbelkompetansen i klinisk arbeid er spesielt viktig fordi raske svingninger i pasientens tilstand gjør pasientarbeidet forutsigbart. Den som innehar dobbelkompetanse, har gode forutsetninger for å ivareta pasienten under skiftende forhold. Slik kompetanse beskrives her, inneholder begrepet også komponenter av ansvar. A ta ansvar beskriver Orvik (2015, s. 295) som «å ha et spekter av forventninger rettet mot seg, om å bidra til god kvalitet $i$ pasientbehandlingen, til kostnadseffektiv tjenesteproduksjon og til å handle med integritet». Bredden i forventningene gjør det nødvendig for sykepleieren å vurdere kritisk om det er mulig å ta ansvar i en gitt 
situasjonen. Sykepleiere som jobber i sykehjem, stilles overfor langt større krav enn de har muligheter til å imøtekomme. De opplever ofte at de svikter og ikke strekker til. Deres dårlige samvittighet er et symbol på at stortinget og regjeringen har spesialisert seg på å vedta de gode hensikter (Vike, Brinchmann, Haukelien, Kroken \& Bakken, 2002). Kommunene har ikke økonomiske forutsetninger til å oppfylle hensikten. Ansvaret skyves nedover til blant andre sykepleierne, som i sitt daglige arbeid møter pasientenes behov for pleie og omsorg. Sykepleieren har ansvaret for pasienten, samt informere og legge til rette for at andre faggrupper kan utføre sine oppgaver knyttet til pasienten (Allen, 2019).

\section{Forskningsmetode og tilgang til feltet}

I studien er det benyttet en fenomenologisk-hermeneutisk tilnærming (Lindseth \& Norberg, 2004). I løpet av sommeren 2019 intervjuet vi sju sykepleiere på fire forskjellige sykehjem, hvorav en av sykepleierne hadde jobbet på to forskjellige sykehjem. Vi gjorde en skriftlig henvendelse til flere sykehjem og fikk tilgang til å gjennomføre intervjuer. Etter at vi hadde gjennomført sju intervjuer, valgte vi å avslutte fordi vi opplevde stort sammenfall i svarene. Fem av intervjuene fant sted på det aktuelle sykehjemmet, og to fant sted hjemme hos informantene. Antall pasienter på de ulike avdelingene varierte mellom 16 og 24. Samtlige informanter opplevde ofte at de hadde ansvarsvakt for flere avdelinger, også for hjemmesykepleien. Det kunne til sammen dreie seg om ansvar for mer enn 70 pasienter. Informantene fikk skriftlig informasjon om studien og samtykkeerklæring. De ble også informert om at de når som helst kunne trekke seg fra undersøkelsen, at datamaterialet ville bli anonymisert, og at opptaket ville bli slettet etter transkripsjon.

\section{Datainnsamling og analyse}

Vi som forskere er begge sykepleiere med tidligere erfaring fra spesialistog kommunehelsetjenesten, og vi har over flere år jobbet med utdanning av sykepleiere og spesialsykepleiere og med videreutdanning innen sykepleie ved høgskole og universitet. Med denne yrkesbakgrunnen kjenner 
vi fagområdet og forskningsfeltet relativt godt. Dette har sine fordeler, men kan også representere en svakhet. Fordelen er at man har innsikt i feltet og kjenner mange av utfordringene som ligger der. Ulempen er at forforståelsen kan gjøre at man blir blind for sider ved feltet, som dermed kan blir oversett (Lykkeslet \& Gjengedal, 2007, Wadel, 2014).

Samtlige informanter hadde mer enn ti års erfaring som sykepleier i sykehjem, og alle hadde jobbet i sykehjem både før og etter innføringen av samhandlingsreformen. Fem av de sju sykepleierne hadde videreutdanning innen geriatrisk sykepleie, psykisk helse, palliasjon, smertelindring og akutt sykdom hos eldre. I intervjuene blir informantene bedt om å fortelle hvilke muligheter og eventuelle begrensninger de opplever å ha for å kunne oppdage forverring i pasientens tilstand. De ble også bedt om å eksemplifisere. Informantenes fortellinger ble fulgt opp med utdypende spørsmål, og de var engasjert i temaet og hadde mye å fortelle og mange eksempler å komme med. Det forelå en semistrukturert intervjuguide. Denne ble forelagt informantene i forkant av intervjuet, og underveis ble den brukt som kontroll på at alle spørsmålene var besvart. Hvert intervju tok cirka en time og ble transkribert av forsker. Studien er godkjent av NSD - Norsk senter for forskningsdata og har referansenummer 648501.

Analysen av data er gjennomført i tre steg: naiv lesning, strukturanalyse og dybdefortolkning. Naiv lesning innebærer at teksten leses flere ganger, og på den måten dannes et bilde av hva teksten handler om. Dette bildet danner så bakgrunnen for strukturanalysen. Strukturanalysen er en fortolkning av teksten som foretas i fire steg: meningsbærende enheter, komprimering, transformasjon, subtemaer og hovedtemaer. Hensikten med strukturanalysen er å få fram tekstens indre struktur og innhold i form av subtemaer, temaer og hovedtemaer. Disse danner i neste fase grunnlaget for dybdefortolkningen. Meningsenheten som kommer fram gjennom denne fortolkningen, blir lest og reflektert mot den naive lesningen, studiens problemstilling og teoretiske perspektiver (Lindseth \& Norberg, 2004).

Følgende tre hovedtemaer tegnet seg gjennom analysen:

- forsvarlighet og kompetanse

- ansvar og ansvarlighet

- oppgaver og oppgavefordeling. 


\section{Funn og diskusjon}

\section{Forsvarlighet og kompetanse}

Informantene i studien sier det er problematisk å være eneste sykepleier på vakt. Spesielt problematisk er det hvis øvrige ansatte ikke har helsefaglig kompetanse. En av informantene uttrykker det slik: « ... og hvis $d u$ da var bare sammen med ufagloerte, da følte $d u$ vel at du var i nedre sjikt av gråsonen på hva som var faglig forsvarlig, og noen ganger følte du at det vippet litt over.» Det krever høy grad av sykepleiefaglig kompetanse å gjøre en faglig forsvarlig og omsorgsfull jobb i sykehjemmene. Det er nå åtte år siden samhandlingsreformen ble gjennomført, og sykehjemmene i vår studie har ikke fått tilført flere stillingsressurser. Noen av informantene sier at hvis alle som skal være på jobb, er på jobb, så går det «stort sett» bra. Det er sykefravær og vakante stillinger som skaper de største problemene. På en av avdelingene i studien er halvparten av sykepleierstillingene vakante, og de blir ofte besatt med ufaglærte.

Informantene har flere fortellinger om pasientsituasjoner som har endt fatalt, eller som har forårsaket store og unødvendige lidelser for pasientene. En av informantene sier: «Da jeg fikk beskjed, var det allerede for sent.» En annen forteller at en dag hun kom på seinvakt, var det én sykepleier og to ufaglærte på jobb. På rapporten fortelles det at en pasient, som en av de ufaglærte har vært hos, har fått omgangssyke med kvalme. Dette reagerer informanten på og går straks inn til pasienten. Hun mistenker at pasienten har fått hjerteinfarkt, og at hun er i ferd med å utvikle hjertesvikt. Hun sier: «Da jeg kom på rommet, så var det på vei å gå over $i$ stuvning til lungene.» Informanten forteller at det ble startet behandling, og pasienten ble sendt på sykehuset og døde tre dager senere. Informanten sier videre: «Hadde det vort sykepleier inne hos pasienten, hadde ting vort oppdaget tidligere ..." Pasienten ble ikke observert på et tilfredsstillende faglig grunnlag, og tegn på alvorlig sykdom ble ikke fanget opp på et tidlig tidspunkt, slik at nødvendige tiltak kunne settes inn i rett tid (Haukelien et al., 2015; Norsk sykepleierforbund, 2018). Informanten sier også at det er usikkert om utfallet av hendelsen ville ha blitt annerledes om det hadde blitt oppdaget tidligere, men at hun er sikker på at pasienten kunne ha vært spart for store lidelser. Og kanskje like viktig: Dette var en veldig dement pasient som kanskje 
hadde hatt best av å vore her sammen med kjente», sier hun. Sykehusinnleggelse medfører ofte merbelastning for sykehjemspasienter, noe som kan unngås hvis sykdomsutviklingen oppdages tidlig og behandlingen kan utføres i sykehjemmet (Donald et al., 2013).

Slik NSF (2018) vurderer grensene for forsvarlighet, finner vi ovennevnte situasjon som ikke faglig forsvarlig. Forverringen av pasientens tilstand blir ikke observert av sykepleier og blir følgelig ikke rapportert. Sykdomsutviklingen oppdages av sykepleier flere timer for sent. Følgelig kom behandlingen i gang for seint til å kunne ha ønsket effekt, både mot sykdomsutvikling og mot symptomene som hadde plaget pasienten hele dagen. Og som informanten sier: Pasienten hadde smerter, hun var tung $i$ pusten, og hun var kvalm, noe som hadde plaget henne i hele denne perioden. Denne fortellingen var ikke unik. Seks av informantene fortalte om lignende hendelser. Den sjuende informanten fortalte ikke om en konkret hendelse, man sa følgende: «Det hender at pasienter lider unødvendig fordi vi mangler kompetanse på avdelingen. Det har jeg selv opplevd flere ganger.» I kommentarene til helsepersonellovens forsvarlighetskrav ( $\mathrm{Hel}$ sedirektoratet, 2018) kan vi lese at kravet til den helsetjenesten som tilbys, skal ligge på et visst nivå. Kravet som rettes mot virksomheter, omfatter en plikt til å tilrettelegge tjenesten slik at personell som utfører tjenesten, blir i stand til å overholde sine lovpålagte plikter (Helsedirektoratet, 2018, kap. 2, \$ 4-5). Informantene opplever sterkt begrenset handlingsrom når de er eneste sykepleier på vakt, og spesielt begrenses handlingsrommet hvis øvrige ansatte er ufaglærte. I slike situasjoner opplever ikke informantene å kunne gi pasienten trygg omsorg.

Det påhviler sykepleieren å påse at hennes medhjelper har nødvendige kvalifikasjoner til å utføre de oppgavene hun pålegger dem (Helsepersonelloven, 1999, kap. 2, \$ 5). I ovennevnte tilfelle var hennes medhjelpere to ufaglærte som ikke hadde nødvendig kompetanse. Flere av informantene sier at de ikke kan bebreide de ufaglærte når noe går galt. En informant sier:

[V]i kan ikke forvente at assistenter skal gjøre observasjoner... men vi er jo bevisst på at da skulle vi heller ikke ha delegert ... etter loven ... men vi er jo påtvunget å delegere - hva kan vi gjøre? Vi har ikke mulighet til å vore overalt hele tiden. 
Informanten er bevisst på at når hun delegerer oppgaver som krever faglig kompetanse, til en ufaglært, risikerer hun at oppgavene ikke blir forsvarlig ivaretatt. Flere studier viser at selv sykepleiere uten videreutdanning som jobber i sykehjem, mangler kompetanse til å oppdage og handle i situasjoner der pasientenes tilstand forverres (Bing-Jonsson, 2019; Dale \& Eikemo, 2018; Dreyer, 2017). De fleste av våre informanter har videreutdanning, noe de sier har kommet godt med - det gjør dem bedre kvalifisert til å utføre behandling, pleie, observasjoner og dokumentasjon av sykepleien. Teoretisk kunnskap, yrkesspesifikke ferdigheter og personlig kompetanse gjør dem kvalifisert til å utføre jobben på en forsvarlig måte (Skau, 2017). Det er i uforutsette situasjoner det kommer tydeligst fram at omfanget av personell med fagspesifikk kompetanse viser seg å være mangelfull. Når det ikke skjer kompetanseoppbygging i helsesektoren, kommer sektoren på etterskudd med de oppgavene den står overfor, og resultatene blir improvisasjoner og nødløsninger (Skau, 2017). Sykepleierne stilles overfor langt større krav enn de har mulighet til å imøtekomme (Vike et al., 2002). Dette begrenser sykepleiernes handlingsrom og muligheter til å oppdage forverring i pasientens tilstand på et tidlig stadium. Sykepleieren er juridisk og faglig-etisk forpliktet til å gi pasientene forsvarlig og omsorgsfull pleie (Helsepersonelloven, 1999, kap. 2, \$4; Norsk sykepleierforbund, u.å.). Ifølge våre informanter er handlingsrommet for å oppfylle forpliktelsene sterkt begrenset, spesielt i situasjoner der de er alene som sykepleier på vakt.

\section{Ansvar og ansvarlighet}

I vår studie opplever seks av våre sju informanter at det er deres ansvar når noe går galt, selv om de er alene som sykepleier på vakt og ikke har handlingsrom til å oppfylle forpliktelsen om forsvarlig og omsorgsfull pleie til alle pasientene. Følgende sitat uttrykker en følelse av ansvar og hjelpeløshet:

Da følte jeg at det var mitt ansvar, samtidig som jeg ikke hadde tatt det ansvaret, samtidig som jeg ikke hadde hatt sjansen eller muligheten til å gå og se til denne pasienten, det var ingenting i pasientens forhistorie som tilsa at dette skulle bli et problem... 
Dette forteller en informant etter at hun hadde opplevd nok et dødsfall fordi pasienten ikke ble observert av personell med nødvendig kompetanse. En annen informant sier at hun prøver å få tid til å gå inn til alle pasientene:

[S]å jeg kan forsikre meg om at det ikke er noe spesielt med dem. Det er så vondt å vite at en pasient på min vakt ikke har fått nødvendig hjelp fordi ingen har oppdaget behovet, eller har latt vore å informere meg om det. For slike ting skjer, det er ikke godt for oss, og det får store konsekvenser for pasienten.

Studien viser at sykepleierne opplever kravet om forsvarlig og omsorgsfull hjelp som deres ansvar å oppfylle, uansett hvor lite ressurser de har tilgjengelig. De opplever at det er deres ansvar når noe går galt, og når de ikke har oppdaget eller har fått beskjed om det. Over tid kan slike opplevelser få helsemessige konsekvenser for sykepleierne (Gautun et al. 2016). En av informantene forteller at hun føler angst når hun er alene som sykepleier på vakt. Hun har tatt konsekvensen av det og har sagt opp stillingen sin. Hun opplever kravene til sin yrkesutøvelse større enn hun har mulighet til å innfri, og at kravene er i ferd med å gjøre henne syk. Flere av informantene opplever å gå på akkord med det de mener er faglig forsvarlig. Tidspresset de utsettes for i jobben, får helsemessige konsekvenser i form av psykiske og fysiske belastninger.

Sentrale myndigheter stiller krav til kommunene om å gi pasienter på sykehjem forsvarlig helsehjelp (helse- og omsorgstjenesteloven, 2011). Kommunene har på sin side ikke tilstrekkelig økonomiske ressurser til å ivareta ansvaret, og de skyver det nedover til sykepleierne, som i sitt daglig arbeid blir stående i vanskelige situasjoner og opplever at ansvaret er deres alene. Som en av informantene sa: "Ansvaret er mitt - uansett.» Forskning viser at halvparten av sykepleierne som jobber i kommunehelsetjenesten, ønsker - eller vurderer - å slutte i jobben. De oppgir blant annet høy arbeidsbelastning - og det at de ofte er eneste sykepleier på vakt - som viktige årsaker. De erfarer at de ikke er i stand til å gi pasientene den hjelpen de trenger (Gautun et al., 2016).

Sykepleierne har overordnet ansvar for sykepleietjenesten, både faglig og organisatorisk (Gautun et al., 2016). Dette innebærer som nevnt at de skal delegere oppgaver til helsefagarbeidere og ufaglærte, med bakgrunn 
i hvilken kompetanse disse innehar. I realiteten innebærer det at sykepleierne sitter igjen med et vidt spekter av oppgaver de strengt tatt ikke kan delegere videre. Orvik (2015) sier at ikke alle oppgaver lar seg delegere videre. Ikke sjelden opplever sykepleierne at behovet for deres hjelp er like stort hos flere pasienter - samtidig (Mæhre, 2017). I kommunehelsetjenesten er sykefraværet 24 prosent blant sykepleierne, og det er høyere på sykehjem enn i hjemmesykepleien (Gautun et al., 2016).

Flere informanter forteller at de alltid er spent på hva som møter dem når de kommer på jobb. De vet hva som står på vaktlisten, men som en sier:

Vaktlisten stemmer sjelden med realiteten. Ofte er de (som er på jobb) både forre og har lavere kompetanse enn det som er planlagt ut fra vaktlisten. Sykefravoer er ikke alltid mulig å erstatte, og hvis det erstattes, er det ofte med en ufagloert der det skulle vort en sykepleier.

Alle informantene tar til orde for at høyere grunnbemanning av sykepleiere vil gjøre dem mindre sårbare. En sier det slik: «Jeg tror bestemt at en høyere grunnbemanning hadde gitt et lavere sykefraver.» Det vil bli flere å fordele arbeid og ansvar på og mindre sjanse for å bli eneste sykepleier på vakt. Det vil gi større handlingsrom med flere faglige ressurser og dermed bedre forutsetninger til å oppdage når en pasient utvikler forverring av sin tilstand, noe som vil gi større mulighet til å oppfylle kravene om faglig forsvarlig og omsorgsfull hjelp. Det vil være naturlig å dra den slutningen at når sykepleiernes handlingsrom utvides, og når faglige ressurser står i forhold til pasientenes behov, vil mulighetene til å ta ansvar for faglig forsvarlig og omsorgsfull pleie til pasientene styrkes. Men med stadig økende sykepleiermangel er det kanskje ikke realistisk med økt grunnbemanning av sykepleiere. Sykepleierne har, spesielt etter innføringen av samhandlingsreformen, fătt ansvar for stadig flere oppgaver. Kanskje er tiden inne for å se på begrensninger av sykepleierens oppgaver og en annen arbeidsfordeling mellom de forskjellige faggruppene. Med en slik begrensning vil sykepleierne få større handlingsrom til å utføre spesifikke sykepleiefaglige oppgaver, og dermed øker mulighetene til å oppdage endringer i pasientenes tilstand på et tidlig stadium. Ansvarsområdet vil være det samme, men flere oppgaver kan overlates til andre. 


\section{Oppgaver og oppgavefordeling}

Informantene opplever i hovedsak ansvarsforholdet mellom sykepleier og lege som avklart. Sykepleieren befinner seg midt i hierarkiet, mellom legen på den ene siden og helsefagarbeideren på den andre. Legen diagnostiserer, behandler og ordinerer, mens sykepleieren administrerer, utfører, understøtter behandling og observerer. Forholdet mellom sykepleier og helsefagarbeider oppleves derimot mer uavklart. En av informantene sier: [D] u må gjøre alt det de andre gjør, i tillegg til sykepleieroppgavene. Hvis ikke blir det sure miner. Jeg opplever at sykepleieroppgaven ikke blir sett på som oppgaver av mine medarbeidere ...» Begge grupper utfører i stor grad de samme oppgavene, men sykepleierne har en rekke andre oppgaver i tillegg. Selv om sykepleiernes oppgaver har økt betraktelig etter innføring av samhandlingsreformen, forventes det likevel at sykepleierne skal delta i alle oppgaver på avdelingen, på linje med øvrig personell. Hvis ikke, vanker det sanksjoner (Johansen, 2019). Sykepleierne må blant annet delta i arbeid som å gjøre rent på kjøkkenet, på skyllerommet og på pasientrom, og de må tømme søppel. Alle dette tar sykepleierne bort fra pasienten og de sykepleiefaglige oppgavene.

Informantenes handlingsrom er så innsnevret av ytre faktorer at de ikke gis muligheten til å oppfylle krav som i utgangspunktet ligger til sykepleierens funksjonsområder. En av informantene sier: «Jeg blir ofte satt $i$ situasjoner hvor jeg må argumentere for mine prioriteringer, for eksempel at andre må ta skyllerommet mens jeg tar sårskiftet.» Våre informanter beskriver det som vanskelig og til dels umulig å kombinere forventningene fra medarbeidere om å delta i daglige gjøremål samt forefallende arbeid i avdelingen og pasientenes behov for sykepleierens spesifikke fagkompetanse. De opplever daglig å stå i en utmattende arbeidssituasjon der deres funksjon ikke forstås og anerkjennes av omgivelsene.

Bare en av våre sju informanter sier at hun ikke gjør oppgaver som kan utføres av andre grupper. Hun konsentrerer seg om spesielle oppgaver og prioriterer å ha oversikt over alle pasientene. «Om noen ikke liker det, bryr jeg meg ikke», sier hun. Hun sier at det er hennes ansvar å sørge for at alle pasientene har det bra, og at det blir oppdaget så tidlig som mulig hvis noen skulle blir syke. Hun har på denne måten skaffet seg 
et handlingsrom som gir henne større mulighet til å oppdage eventuell sykdomsutvikling hos pasientene. Rammebetingelsene sykepleierne jobber innenfor, er ikke lagt for å utføre sykepleie i tråd med de tradisjonelle sykepleiefaglige verdiene (Korsvold \& Thomassen, 2018). Forskning viser at 54 prosent av sykepleierne sier at de daglig utfører oppgaver som helsefagarbeidere kunne ha gjort (Johansen, 2019). Dette er et problem arbeidsgiverne bør rydde opp i, blant annet fordi det har utviklet seg til å bli et arbeidsmiljøproblem for noen av sykepleierne (Korsvold \& Thomassen, 2018).

Informantene $\mathrm{i}$ vår studie viser til hvordan deres arbeidshverdag er under kontinuerlig endring hva oppgaver angår. Når det meldes en utskrivningsklar pasient fra sykehuset, utløser det en rekke aktiviteter som må utføres av sykepleier på sykehjemmet. Sykepleieren er koordinatoren i dette arbeidet, som består i alt fra å klargjøre egnet rom til å finne egnet seng og tilbehør til sengen og annet utstyr som svarer til pasientens behov. Hun må bestille medisiner og annet nødvendig utstyr fra apotek. Hun må bestille egnet kost, kontakte pårørende og kontakte fysioterapeut, for å nevne noe. Noen av disse oppgavene kan sykepleier delegere til andre ansatte. De fleste må de utføre selv. Mye informasjon, dokumentasjon og forordninger går elektronisk, noe som betyr at sykepleieren bruker en stor del av arbeidsdagen ved datamaskinen. Sykepleierne bidrar til å koble tjenesteforløpet til pasienten sammen, selv om de ulike aktørene ikke møtes. Sykepleiere fungerer som en sentral for koordinasjon av informasjon fra og til de mange spesialiserte yrkesgruppene som samhandler om pasientene (Allen, 2019). Selv om alt sykepleieren foretar seg, omhandler pasienten, bidrar det organisatoriske arbeidet til å trekke sykepleieren ut av direkte pasientkontakt og til å innskrenke handlingsrommet sykepleieren trenger for å kunne oppdage endringer i pasientens tilstand.

Flere av sykepleierne i vår studie tar til orde for at det er et arbeidsgiveransvar å legge forholdene til rette slik at sykepleierne skal kunne gjøre en faglig forsvarlig jobb. De ønsker seg en gjennomgang av arbeidsoppgavene de har, og en fordeling av oppgavene ut fra hvilken kompetanse som trengs for å utføre de ulike oppgavene. På et av sykehjemmene er dette arbeidet allerede i gang. Bergland et al. (2010) viser til at sykepleiere 
opplever sitt funksjonsområde som lite avgrenset. Vi opplever likevel en ambivalens hos informantene når det gjelder å gi slipp på oppgaver. Selv om de ser fordelene med å gå på topp (å ha et overordnet sykepleiefaglig ansvar) når det bare er en sykepleier på vakt, ser de også ulempene dette fører til. Ingen av informantene ønsket å bli fratatt muligheten til å stelle pasienten fordi, som en uttrykte det, «det gjøres mange viktige observasjoner $i$ stellet av de som har kompetanse til det». Mulighetene til å ha overblikk og gjøre gode observasjoner av alle pasientene samt utføre sykepleiefaglige prosedyrer er bedre når sykepleier ikke bindes opp hos én eller få pasienter. Samtidig begrenses mulighetene til å oppnå nærhet og kontakt samt til å foreta gode observasjoner, som de ofte får i stellesituasjoner med den enkelte pasienten. Informantene opplever altså uansett at handlingsrommet innskrenkes, og at de daglig står i faglige dilemmaer så lenge sykehjemmene ikke er tilstrekkelig bemannet med sykepleiere.

Sykehjemmene har, etter samhandlingsreformen, utviklet seg til å bli institusjoner som krever høyere klinisk og organisatorisk kompetanse hos sykepleierne. Å ha oversikt over avdelingen forutsetter at sykepleieren innehar klinisk kompetanse. Samtidig må vedkommende ha kunnskap og kompetanse om kompleksiteten i en stor organisatorisk virksomhet som helsesektoren - og om hvordan denne fungerer. Når sykepleieren skal administrere både medarbeidere som jobber i avdelingen og andre faggrupper som deltar i direkte pasientrelaterte handlinger, kreves organisatorisk kompetanse (Orvik, 2015).

Studien viser at én måte å skaffe sykepleierne større handlingsrom på er å endre fordelingen av oppgaver mellom faggruppene. Spesielt bør sykepleierne fritas for oppgaver som ikke er direkte pasientrettet, og som kan utføres av andre. Det vil gi sykepleierne større handlingsrom til å følge opp den enkelte pasient og til å kunne oppdage tegn på et endret sykdomsbilde tidligere.

\section{Avslutning}

Sykepleierne i vår studie opplever at handlingsrommet for å oppdage forverring i pasientens tilstand på et tidlig stadium i sykdomsutviklingen er sterkt begrenset. 
Våre informanter har delt erfaringer fra sine arbeidshverdager i sykehjem. Fortellingene deres omhandler alvorlige situasjoner der pasientenes liv er satt på spill, og som i noen tilfeller har endt med døden. Sykepleierne forteller at pasientenes helsetilstand har utviklet seg til alvorlig sykdom uten at sykepleier har blitt orientert eller har vært i posisjon til å gjøre nødvendige observasjoner og foreta intervensjon. De forteller videre at pasienter lider med smerter, pusteproblemer, kvalme og angst fordi slike symptomer ikke blir forstått og fortolket av personell med faglig kompetanse.

I flere tiår har mangelen på sykepleiere vært økende, og følgene av dette representerer noen av de største problemene i helsesektoren. Konsekvensene av - og årsakene til - sykepleiermangelen er dokumentert i utallige studier og rapporter, inkludert denne studien. Tendensen er likevel at mangelen på sykepleiere øker. Flere sykepleiere slutter fordi arbeidspresset er for stort, og fordi ansvaret ikke er til å leve med.

Situasjoner som dette er belastende og gir ofte helsemessige konsekvenser for sykepleierne. Sykefraværet er stort. De sykepleierne som er igjen i avdelingene, opplever derfor ytterligere krysspress mellom forventninger og krav på den ene siden og mulighetene til å utføre forsvarlig sykepleie og pasientomsorg på den andre siden.

Våre informanter har alle jobbet i sykehjem siden før samhandlingsreformen ble gjennomført, og følgelig har de opplevd de endringene denne har ført med seg. Studien viser med all tydelighet at deres handlingsrom til å oppdage forverring i pasientenes tilstand på et tidlig stadium i sykdomsutviklingen er sterkt begrenset. De er ofte eneste sykepleier på vakt på grunn av sykefravær og vakante stillinger. En økende andel av deres medarbeidere er ufaglærte. Studien viser at innskrenkning i sykepleiernes handlingsrom fører til uforsvarlige situasjoner som gir store konsekvenser for pasientene, og som tynger sykepleierne ved at de føler at det er deres ansvar når noe går galt.

Studien avdekker et behov for å gi sykepleierne ryddige og avklarte arbeidsforhold, og for at det vises aktelse og anseelse for deres innsats. Isteden pålegges de stadig flere oppgaver og mer ansvar. Hvis det ikke iverksettes omfattende tiltak for å beholde de sykepleierne vi har, rekruttere flere til yrket og definere sykepleiernes arbeidsområde og 
ansvarsomfang klarere, er vi redd mangelen på sykepleiere vil gi flere og mer alvorlige konsekvenser for pasientene.

\section{Referanser}

Aiken, L. H., Cimiotti, J. P., Sloane, D. M., Smith, H. L., Flynn, L. F. \& Neff, D. F. (2011). Effects of nurse staffing and nurse education on patient deaths in hospitals with different nurse work environments. Medical Care, 49(12), 1047-1053. https:// doi.org/10.1097/mlr.obo13e318233ob6e

Aiken, L. H., Clarke, S. P., Cheung, R. B., Sloane, D. M. \& Silber, J. H. (2003). Educational levels of hospital nurses and surgical patient mortality. JAMA, 29o(12), 1617-1623. https://jamanetwork.com/journals/jama/fullarticle/197345

Aiken, L. H., Sloane, D. M., Bruyneel, L., Van Den Heede, K., Griffiths, P., Busse, R., ... Sermeus, W. (2014). Nurse staffing and education and hospital mortality in nine European countries: A retrospective observational study. The Lancet, 383(9931), 1824-1830. https://doi.org/10.1016/So140-6736(13)62631-8

Allen, D. (2019). Sykepleiernes usynlige arbeid: Organisering av sykehus og pasientomsorg. Bergen: Fagbokforlaget.

Andersson, Å., Frank, C., Willman, A. M., Sandman, P.-O. \& Hansebo, G. (2018). Factors contributing to serious adverse events in nursing homes. Journal of Clinical Nursing, 27(1-2), e354-e362. https://doi.org/10.1111/jocn.13914

Bergland, Å., Vibe, O. \& Martinussen, N. (2010). Hvordan få sykepleiere til å se på sykehjem som en fremtidig arbeidsplass? Sykepleien, 98(1), 52-54. https://doi. org/10.4220/sykepleiens.2010.0005

Bing-Jonsson, P. C, Hofoss, D., Kirkevold, M., Bjørk, I. T. \& Foss, C. (2016). Sufficient competence in community elderly care? Results from a competence measurement of nursing staff. BMC Nursing, 15(5). https://doi.org/10.1186/s12912-016-0124-Z

Bing-Jonsson, P. C. (2019). Avansert klinisk sykepleie i helse- og omsorgstjenester i kommunene. I L. M. Fagerstrøm (Red.), Avansert klinisk sykepleie. Gyldendal.

Bing-Jonsson, P. C., Foss, C. \& Bjørk, I. T. (2016). The competence gap in community care: Imbalance between expected and actual nursing staff competence. Nordic Journal of Nursing Research, 36(1), 27-37. https://doi.org/10.1177\%2Fo107408315601814

Bragadóttir, H. \& Kalisch, B. J. (2018). Comparison of reports of missed nursing care: Registered nurses vs. practical nurses in hospitals. Scandinavian Journal of Caring Sciences, 32(3), 1227-1236. https://doi.org/10.1111/scs.12570

Briggs, R., Coughlan, T., Collins, R., O’Neill, D. \& Kennelly, S. P. (2013). Nursing home residents attending the emergency department: Clinical characteristics and outcomes. QJM: An International Journal of Medicine, 106(9), 803-808. https:// doi.org/10.1093/qjmed/hct136 
Bruvik, F., Drageset, J. \& Abrahamsen, J. F. (2017). Fra sykehus til sykehjem Hva samhandlingsreformen har ført til. Sykepleien forskning, 12, 8-8. https:// sykepleien.no/forskning/2017/o2/fra-sykehus-til-sykehjem

Dale, G. H. \& Eikemo, S. B. (2018). Kompetanseheving i eldreomsorgen kan gjøre helsepersonell tryggere. Sykepleien, 107(1). https://doi.org/10.4220/ Sykepleiens.2018.74579

Donald, F., Martin-Misener, R., Carter, N., Donald, E. E., Kaasalainen, S., WicksonGriffiths, A., ... DiCenso, A. (2013). A systematic review of the effectiveness of advanced practice nurses in long-term care. Journal of Advanced Nursing, 69(10), 2148-2161. https://doi.org/10.1111/jan.12140

Dreyer, A. (2017). Akutt forverring av tilstanden til eldre pasienter i sykehjem. I S.-T. D. Fredriksen \& K. Halvorsen (Red.), Fenomener i intensivsykepleie (s. 172-190). Oslo: Cappelen Damm Akademisk.

ECON. (2009). Bemanning i kommunal pleie og omsorg (Rapport nr. 2009-072).

Gautun, H., Øien, H. \& Bratt, C. (2016). Underbemanning er selvforsterkende: Konsekvenser av mangel på sykepleiere i hjemmesykepleien og sykehjem (NOVArapport 6/2016). Oslo: Norsk institutt for forskning om oppvekst, velferd og aldring. Hentet fra https://sykepleien.no/sites/default/files/til-trykk-nova-r6-1625-mai-2016_2.pdf

Haug, C. (2012). Ferdigbehandlet? Tidsskrift for Den norske legeforening, 132(10), 1197. https://tidsskriftet.no/2012/05/minileder/ferdigbehandlet

Haukelien, H., Vike, H. \& Vardheim, I. (2015). Samhandlingsreformens konsekvenser $i$ de kommunale helse og omsorgstjenestene: Sykepleieres erfaringer (TF-rapport nr. 362). Hentet fra https://intra.tmforsk.no/publikasjoner/filer/2794.pdf

Helse- og omsorgsdepartementet. (2009). Samhandlingsreformen - rett behandling på rett sted - til rett tid (St.meld. nr. 47 (2008-2009)). Hentet fra https://www. regjeringen.no.

Helse- og omsorgstjenesteloven. (2011). Lov om kommunale helse- og omsorgstjenester m.v. (LOV-2011-06-24-30). Hentet fra https://lovdata.no/ dokument/NL/lov/2011-06-24-30

Helse- og omsorgsdepartementet. (2015). Fremtidens primorhelsetjeneste - noerhet og helhet. (Meld. St. 26 (2014-2015)). Hentet fra https://www.regjeringen.no

Helsedirektoratet. (2018). Helsepersonelloven med kommentarer (Rundskriv IS-IS-8). Hentet fra https://www.helsedirektoratet.no/rundskriv/helsepersonelloven-medkommentarer

Helsepersonelloven. (1999). Lov om helsepersonell m.v. (LOV-1999-07-02-64). Hentet fra https://lovdata.no/dokument/NL/lov/1999-07-02-64

Holmeide, A. \& Eimot, M. (2010). Bemanning i kommunal helse- og omsorgstjeneste. Oslo: Analysesenteret. 
Norsk sykepleierforbund. (u.å.). Yrkesetiske retningslinjer for sykepleiere. Hentet fra https://www.nsf.no/sykepleiefaget/yrkesetiske-retningslinjer

Johansen, L. B. (2019, 14. april). Potetproblemet. Sykepleien, 107(1), 155-156. https:// sykepleien.no/meninger/innspill/2019/04/potetproblemet

Kalisch, B. J. \& Xie, B. (2014). Errors of omission: Missed nursing care. Western Journal of Nursing Research, 36(7). https://doi.org/10.1177/0193945914531859

Kolstø, Å. M. \& Sørbø, J. (2018). NAVs bedriftsundersøkelse 2018. Hentet fra www.nav. no.analyser

Korsvold, L. A. \& Thomassen, O. J. (2018). Tiltak for å bedre sykepleiernes arbeidsmiljø er ofte individrettet. Sykepleien forskning, 13, 21-21. https://doi. org/10.4220/Sykepleienf.2018.71109

Lindseth, A. \& Norberg, A. (2004). A phenomenological hermeneutical method for researching lived experience. Scandinavian Journal of Caring Sciences, 18(2), 145-153. https://doi.org/10.1111/j.1471-6712.2004.00258.x

Lykkeslet, E. \& Gjengedal, E. (2007). Methodological problems associated with practice-close research. Qualitative Health Research, 17(5), 699-704. https://doi. org/10.1177/1049732307299216

Mæhre, K. S. (2017). «Vi må ha hjelp!» Pasienter, pårørende og sykepleiere sine erfaringer fra en forsterket sykehjemsavdeling etter Samhandlingsreformen (Doktoravhandling), Nord universitet, Bodø.

Norsk sykepleierforbund. (2018). Forsvarlighet: Om faglig kompetent og omsorgsfull sykepleie (4. utg). Oslo: Norsk sykepleierforbund. https://www.nsf.no/ Content $/ 3851110 /$ cache $=20191202100138 /$ NSF\%2oForsvarlighetshefte-april_2018.pdf NOU 2018: 16. (2018). Det viktigste først - Prinsipper for prioritering i den kommunale helse- og omsorgstjenesten og for offentlig finansierte tannhelsetjenester. Hentet fra https://www.regjeringen.no.

Orvik, A. (2015). Organisatorisk kompetanse: Innføring i profesjonskunnskap og klinisk ledelse. Oslo: Cappelen Damm Akademisk.

Skau, G. M. (2017). Gode fagfolk vokser: Personlig kompetanse i arbeid med mennesker (5. utg.). Oslo: Cappelen Damm Akademisk.

Stewart, R. (1982). Choices for the manager: A guide to managerial work and behaviour. Englewoord Cliffs, NJ: Prentice-Hall.

Stewart, R. (1989). Studies of managerial jobs and behaviour: The ways forward. Journal of Management Studies, 26(1), 1-10. https://doi. org/10.1111/j.1467-6486.1989.tboo713.x

Vike, H., Brinchmann, A., Haukelien, H., Kroken, R. \& Bakken, R. (2002). Maktens samvittighet: Om politikk, styring og dilemmaer i velferdsstaten. Oslo: Gyldendal Akademisk.

Wadel, C. (2014). Feltarbeid i egen kultur. Oslo: Cappelen Damm Akademisk. 



\title{
Kulturell trygghet for den samiske pasienten i møter med helsevesenet
}

\author{
Randi Inger Johanne Nymo \\ UiT Norges arktiske universitet
}

\begin{abstract}
This chapter focuses on how nurses should act towards Sámi patients in order to promote cultural safety in meetings with the healthcare system. The method applied is a secondary analysis of interviews of 12 persons, as well as participatory observations. The findings show that there still are barriers between health personnel and Sámi patients due to the historic legacy and lack of knowledge. The barriers can be linguistic challenges, different understandings of an illness's causes and authority distance due to the notion of the Sámi as inferior human beings.
\end{abstract}

Keywords: Sámi patients, nursing, cultural safety, barriers in nursing, historical legacy

\section{Introduksjon}

Denne artikkelen har som mål å gi en forståelse av behovet for at sykepleiere har kunnskap om samisk historie, kultur og sykdomsforståelser. Innsikt i historiske fakta, samiske kulturytringer og verdensforståelser vil gi grunnlag for bedre sykepleie. Sykepleiere møter samiske pasienter på alle nivåer i helsetjenesten. Sykepleierne skal tenke helhetlig og se mennesket bak sykdommen. Pasientrollen bringer mennesket i en ukjent situasjon. Den syke er mer eller mindre bekymret for undersøkelse, diagnosesetting og behandling. Helsevesenet, med sine regimer, representerer

Sitering av denne artikkelen: Nymo, R. I. J. (2020). Kulturell trygghet for den samiske pasienten i møter med helsevesenet. I B. L. L. Kassah, H. Nordahl-Pedersen \& W.-A. Tingvoll (Red.), Handlingsrom for profesjonalisert velferd: Kommunale tjenester for helse, omsorg og barnevern (Kap. 10, s. 221-242). Oslo: Cappelen Damm Akademisk. https://doi.org/10.23865/noasp.114.ch1o

Lisens: CC-BY 4.o. 
en autoritet. Medisinen som fag har sin arv fra naturvitenskapene. Det er etablert standarder for hva som er normalt, og for hva som er avvik (Martinsen, 200o). Denne tenkningen bidrar til avstand mellom pasient og helsepersonell, og pasienten kan føle seg fremmedgjort (Lassenius \& Severinsson, 2014). Innenfor medisinsk tenkning blir kroppen sett som en maskin. Sykdom blir sett som feil i maskineriet. Et menneskes kultur og levesett har lett for å bli oversett (Thornquist, 2003). Det er viktig å tenke at kroppen som erfarende subjekt ikke kan ignoreres i et menneskes voren $i$ verden, som Heidegger (2007) uttrykker det, eller voeren til verden (Merleau-Ponty, 1994). Dersom pasienten tilhører andre kulturer enn den vestlige, kan avstanden kjennes enda større (Nymo, 2003, 2011).

Per Fugelli oppdaget under sin legegjerning i Porsanger i 1980-årene at samers møter med helsevesenet hadde barrierer, både på grunn av språkproblemer og på grunn av forståelser av helse og sykdom (Fugelli, 1986). Samisk kultur og språk har blitt ansett som noe laverestående og primitivt. Evolusjonsteorien, som forklarer alt liv som utvikling fra laverestående til høyerestående trinn, ga rom for å vurdere samenes og samisk kulturs annerledeshet som primitive raseegenskaper (Christensen, 1997). Medisinen som fag var med på å forsterke dette bildet ved å finne «kroppsfeiler» hos samene. Dette skjedde under raseforskningen fra slutten av 18oo-tallet og opp mot andre verdenskrig. Skallemålinger av samene er en del av raseforskningen. Man hevdet at kortskallede mennesker hadde mindre intelligens enn langskallede. Samene var angivelig kortskaller, mens mennesker av germansk rase var langskaller. Det skulle dokumenteres at samene tilhørte en laverestående rase (Kyllingstad, 2004, Hjortfors, 2012).

Medisinen som fag trengte «normale kropper» som modeller, og den normale kroppen var hos «den germanske rase». Sesjonslegene Müller og Grøn beskrev motstykket til samiske rekrutter:

... alle den germanske races bedste egenskaper: stor og stærk benbygning kraftig muskulatur, veldannede hænder og fødder og skarpt udviklede sanseorganer; ogsaa i aandelig henssende synes den norske befolkning at være høit begavet; derom vidner deres klare, gløgge blikk og hurtige opfatningsevne. (Stordahl, 1997, s. 140). 
Medisinfagets historie forklarer at mange samiske pasienter opplever helsepersonell i stor maktposisjon (Hjortfors, 2012; Nymo, 2003, 2011; Bongo, 2002, 2012; Nymo \& Minde, 2014; Hansen, 2015). Sametingsrådsmedlem Henrik Olsen sier at raseforskningen sitter i samenes kollektive minne (Fugelsnes, 2016). Siden Fugellis oppdagelser påvises det fortsatt problemer eller barrierer hos samer, både når det gjelder å oppsøke helsevesenet og i møte med det (NOU 1995: 6, Nystad, Melhus \& Lund, 2006). Mange samer føler fortsatt at de diskrimineres av helsepersonell (Hansen, 2015).

Et annet moment er at vestlig medisin også kan oppleves mangelfull i behandlingsøyemed. Mange samer henvender seg til folkemedisinske behandlere, gjerne i det skjulte, for å supplere medisinsk behandling (Nymo, 2003, 2011; Bongo, 2002, 2012; Hætta, 2010; A. I. L. Larsen, 2018). Behandlinger kombineres for sikkerhets skyld. Folkemedisin brukes for å forsterke legemedisinens behandling (Nymo, 2003, 2011). Dette kan øke avstanden mellom samene og helsevesenet.

\section{Nåsituasjonen}

Per Fugellis (1986) oppdagelser grunnla en forståelse av at samers helsebehov ikke var godt nok imøtekommet. Nasjonale føringer har signalisert at helsepersonell må ha kunnskap om samisk kultur og samfunnsliv og være bevisst på at samer får tilbud på sitt språk (NOU 1995: 6; Sosial- og helsedepartementet, 2001). Forskrift om felles rammeplan for helse- og sosialfagutdanninger er en klar nasjonal instruks om å gi kandidatene kunnskap om og forholder seg til helse- og sosialpolitikk og kan anvende oppdatert kunnskap om helse- og velferdssystemet, lover, regelverk og veiledere i sin tjenesteutøvelse. Kandidaten skal også kjenne til samers rettigheter, og ha kunnskap om og forståelse for samenes status som urfolk (Forskrift om felles rammeplan for helse- og sosialfagutdanninger, 2017).

Føringene fra nasjonalt hold har ikke kommet av seg selv. Samiske helsearbeidere og politikere har fremmet samers kulturelle helsebehov siden slutten av 1970-årene. NOU 1995: 6 og Sosial og helsedepartementet ${ }^{1}$

1 Sosial- og helsedepartementet heter nå Helse- og omsorgsdepartementet. 
(2001) sin handlingsplan er et resultat av dette arbeidet. Det ble utløst statlige midler til forskning og utvikling, administrert av Sametinget. Dette initierte mye forskning som løfter fram samisk samfunnsliv, kulturell forståelse av helse og sykdom og språkbarrierer i helse- og sosialvesenet (Eidheim \& Stordahl, 1998; Tronvoll et al., 2004). Samisk nasjonal kompetansetjeneste - psykisk helsevern og rus (SANKS) og Senter for samisk helseforskning (SSHF) har bidratt med mye forskning (Finnmarkssykehuset, 2019; Senter for samisk helseforskning, 2019). Universitetet i Tromsø har levert forskning på temaet samisk helse også innenfor sykepleie (Nymo, 2011; Bongo, 2012; L. S. S. Larsen, 2017; A. I. L. Larsen, 2018; Hamran \& Blix, 2015).

\section{Problemstilling}

Hvordan kan sykepleiere bidra til kulturell trygghet for den samiske pasienten i møtet med helsevesenet?

\section{Teoretiske innganger}

\section{Forståelser av sykdom}

Helse- og sykdomsforståelser er, som nevnt, kulturelt betinget. Samene har en kulturbakgrunn som tradisjonelt bryter med biomedisinsk modell. Den biomedisinske modellen er reduksjonistisk (Grimen, 2004; Kassah, Nordahl-Pedersen \& Tønnesen, 2014). Helse reduseres til fravær av sykdom. Sykdom reduseres til tilstander i mindre og mindre kroppsdeler, helt på cellenivå, og til begrensede biologiske prosesser (Bullington, 2004). I en folkemedisinsk modell er forståelse av helse og sykdom knyttet til kultur, hvor aktørenes kunnskap, tenkning, språk og symboler er førende. Man ser sykdom som ubalanse i livet. I denne forståelsen er det fire relasjoner hvor ubalanser kan forårsake uhelse og sykdommer. De er (Mathisen, 2000):

a) i det enkelte mennesket

b) i naturen som omgir menneskene 
c) i den sosiale verdenen rundt mennesket

d) i det spirituelle eller «overnaturlige»

En slik sykdomsforståelse finnes hos samene (Mathisen, 200o). Forskning har vist at mange samer støtter seg til kulturbasert helse- og sykdomsforståelse (Nymo, 2011; Bongo, 2012; A. I. L. Larsen, 2018).

Den folkemedisinske sykdomsforståelsen ble etter hvert farget av kristendommens komme til samene. Det skjedde gradvis misjonering fra rundt år 1000 fram til 1700-tallet (Kjølaas, 1996; Meistad, 1999). Den folkemedisinske modellen ble dermed utvidet. I en kristelig kontekst kan sykdom forstås som ubalanse i forholdet til Gud. I læstadiansk religionsforståelse snakker man om å være «i sjelenød», som betyr en opplevelse av å «ikke tro seg som kristen». Enkelte opplever det så sterkt at de føler seg syke. Predikanten kontaktes gjerne for å gå dypere inn i fenomenet, slik at den syke får gjort «forbedring» (Nymo \& Minde, 2014).

Helsevesenets aktører handler som nevnt i tråd med vestlig medisinsk tenkning. I det medisinske rommet forventes tydelig kommunikasjon. Pasienten anmodes om å presentere sitt problem tydelig. Det skal utpekes et bestemt område på kroppen der pasienten har vondt. Bruk av samtale- og sjekklister styrer gjerne kommunikasjonen, slik at det kan være vanskelig å etablere hverdagslige samtaler. Samhandlingen påvirkes også av teknologien, som fordrer at personalet retter oppmerksomheten mot instrumenter og apparatur. Pasientens tilstand leses ut av apparatur og innenfor medisinske termer. Man jakter etter diagnoser.

Slik praksis bryter med alminnelige menneskelige omgangsformer. Mennesker bruker ikke abstrakte begreper når de formidler helseproblemer; de forteller historier (Sørly, 2019). Samisk kommunikasjon er ikke direkte - det er vanlig å starte med fortellinger, for så å sirkle seg inn til hva saken gjelder (Bongo, 1986, 2012; Nymo, 2003, 2011; Sørly, Nygaard \& Mathisen, 2018). Dernest er samer forsiktig med hva de sier om sine plager, om sin sykdom, fordi de tenker at det å snakke om sykdom kan få den til å spre seg (Sköld, 1998, Bongo, 2012). Da koppeepidemien kom til Sverige på 170o-180o-tallet, kalte samer sykdommen for «Det Store Navnet». Dette var for å unngå å ta det virkelige navnet i sin munn, noe de mente kunne få sykdommen til å eksplodere (Sköld, 1998, Bongo, 2012). 


\section{Brukermedvirkning}

Brukermedvirkning er et av tre elementer i kunnskapsgrunnlaget for sykepleiepraksis:

1) forskningsbasert kunnskap

2) erfaringsbasert kunnskap

3) brukerkunnskap eller brukermedvirkning

Pasientens verdier, ønsker og behov skal vektlegges, og autonomien til pasienten eller brukeren skal være retningsgivende for behandling, pleie og omsorg (Kristoffersen, 2016). Enhver situasjon inneholder muligheter og begrensinger. Moralen er en del av vårt dagligliv og uttrykkes i forholdet mellom mennesker, og i måten vi er på. Omsorg er å frigjøre hverandres ressurser. Sykepleieren må se seg tid til å lytte til pasientens fortellinger. Mulighetene for brukermedvirkning vil da åpne seg, og med det følger helsegevinst.

Helsepersonellet er definert som de kyndige i sykdom, diagnostisering og behandling. Dette har man riktignok prøvd å tone ned ved at brukermedvirkning er kommet inn. Det er en del av demokratiseringen av helse- og sosialvesenet. Samtidig er etikken løftet fram, og med det autonomiprinsippet. Pasientens autonomi og rettigheter skal sikres gjennom jus og lovverk: pasient- og brukerrettighetsloven (1999) og helsepersonelloven (1999). Pasienten har rettigheter, og personalet har forpliktelser ut fra disse lovene.

\section{Sykepleie}

Sykepleie er en faglig virksomhet basert på et kunnskapsgrunnlag som sikrer forsvarlig utøvelse. Som nevnt skal sykepleiehandlinger gå ut fra forskning, erfaring og brukermedvirkning. For å gi omsorg må man først og fremst se den andre (Martinsen, 2000). Det gjelder å få en situasjonsforståelse ved å våge seg frampå i møtet med den andre. Situasjonsforståelsen oppnås gjennom innsikt i den andres livssituasjon. Sykepleieren må tilstrebe å møte den andre med tillit (Martinsen, 2000). For å oppnå ekte omsorg må sykepleieren forholde seg til vedkommende ut fra en holdning som anerkjenner den andre ut fra hans eller hennes situasjon. 
Pasienten kan da framstå som en person, og sykepleieren blir i stand til å gi personsentrert sykepleie (Forsberg, 2016). I personsentrert sykepleie ligger nøkkelen til kulturell trygghet.

\section{Metodologi og materiale}

\section{Datainnhenting}

Bokkapitlet er basert på empirisk materiale. Det empiriske nedslagsfeltet for studien er den delen av Sápmi som strekker seg fra kysten av nordre Nordland og Sør-Troms til Nord-Sverige. Samene som bebor området, har vært utsatt for assimileringspolitikk. Norsk og svensk språk har mer eller mindre fortrengt samisk.

Problemstillingen søkes besvart ved bruk av eksisterende materiale, det vil si fra hovedfag og doktorgrad i sykepleie (Nymo, 2003, 2011). Datamaterialet er supplert med intervjusamtale høsten 2018 med en eldre samisk kvinne på svensk side. Hun har vært alvorlig syk.

I hovedfagsarbeidet gjorde jeg intervju med fire personer, tre kvinner og en mann, i aldersspennet 30 til 80 år. Intervjuene skjedde i informantenes hjem og var samtalebasert. Samisk og norsk språk ble brukt om hverandre overfor de eldre. De to yngste brukte norsk språk. Alle fire var strategisk utvalgt, de tilhørte ressurssterke samiske slekter, og de bodde i ulike samiske bygder i Ofoten og Sør-Troms (Nymo, 2003).

I doktorgradsarbeidet gjorde jeg deltakende observasjoner på temabaserte månedlige helsetreff på Várdobáiki samiske kultursenter, kombinert med intervju. Tema var helse- og sykdomsrelatert og tradisjonell praktisk kunnskapsutøvelse. Det kunne handle om dyrevelferd, om ivaretakelse og stell av skiutstyr etter vinterens bruk, samt om å gå til skogs for å lete etter nye skiemner for neste sesong. Foredragsholderne var lokale, noen ganger kom de langveis fra. Jeg observerte samhandlingen mellom deltakerne og mellom deltakerne og personalet, inkludert foredragsholderne. Jeg erfarte hvordan deltakerne supplerte hverandre gjennom å dele minner for å få fram kunnskap. Jeg gled inn som både deltaker og helsepersonell. Observasjonene ble komplettert med intervju av åtte personer (Nymo, 2011). Deltakerne var fra Evenes, Skånland, Tjeldsund, Narvik og Ballangen kommuner. Informantene var strategisk valgt blant både 
aktive og mindre aktive i plenum. Intervjuene ble gjort i deltakernes hjem og ble tatt opp på lydbånd og senere transkribert.

På helsetreffene noterte jeg det jeg så og erfarte i samspillet. Noen ganger ble jeg brukt som sykepleier, for eksempel på treff med influensavaksinering, hvor jeg avlastet helsesøster ved å observere etter at vaksiner var gitt. På noen helsetreff kunne jeg supplere med mine erfaringer som same oppvokst i en markebygd. I slike seanser erfarte jeg at jeg var «en av deltakerne», en «innenfor», ikke en fremmed.

Når det gjelder materialet fra Nymo (2003, 2011), mener jeg, ut fra min samiske kulturelle kompetanse, at dataene fremdeles har gyldighet. I Sørly et al. (2018) opplever deltakerne noen av de samme utfordringer som deltakerne i Nymo (2003, 2011) gjør. Det er slik at dypkulturelle strukturer er til stede, så å si spikret fast, og de byttes ikke så lett ut som materielle kulturelementer. I gitte sammenhenger viser den immaterielle kulturen seg i tenkning og handling (Myrvoll, 2008).

\section{Etiske overveielser}

I kvalitativ forskning kommer forskeren innenfor informantenes private sfærer, fordi forskeren gjerne er på jakt etter «rike fortellinger». I en slik tilnærming er faren for å trå over en urørlighetssone stor (Foss \& Ellefsen, 2004). Dette må forskeren være bevisst på. Prosjektet Nymo (2011) ble meldt til Norsk samfunnsvitenskapelig datatjeneste (NSD) ${ }^{2}$ og ble også forelagt, behandlet og godkjent av Regional etisk komité nord (REK nord). Etter doktorgraden gjorde jeg en henvendelse til REK for bruk av datamaterialet til publiseringer. REK samtykket. Samtalen med informanten som har vært alvorlig syk, er meldt til NSD og er meldepliktig. Datamaterialet foreligger i anonymisert form.

\section{Tolkning og analyse}

Forskernes forforståelser har betydning for tolkning og analyse (Wifstad, 1994; Gadamer, 1989). I de tilfeller hvor forskerne har kjennskap til feltet

2 Norsk senter for forskningsdata (NSD) het den gangen Norsk samfunnsvitenskapelig datatjeneste. 
som informantene befinner seg $\mathrm{i}$, er det lett å operere som «knowers» (Nakata, 2007). Erfaringer hos forsker har med andre ord betydning for fortolkning av informantens berettelser. Det kan være både en styrke og en svakhet. Det er viktig å erkjenne at en forsker utenfra har sine forståelser med seg og resonnerer ut fra dem.

Jeg har prøvd å være bevisst på at informantene var de førende, og jeg har prøvd ikke å la mine «knowers»-horisonter bli for framtredende. Min erfaring er at noen ganger var det bra å være en som kjenner kulturen. Sammen med informantene kunne felles kulturforståelse og bruk av samisk språk gi en felles forståelse av aktuelle situasjoner eller temaer. Så er det da også viktig å erkjenne det faktum at forskeren sin lokale status etter hvert kan bli utdatert (Fossåskaret, 2007). Ting har forandret seg siden jeg flyttet fra markebygda.

\section{Analysen}

Data er som nevnt basert på tidligere innsamlet materiale. Det blir gjort en andregangsanalyse. Analysen startet ved leting i Nymo (2003, 2011) etter data til denne tekstens formål. Fortolkningen startet samtidig. Jeg har meningskodet, meningsfortettet og meningsfortolket materialet i tråd med Kvale og Brinkmann (2015). I en ny analyse av data hadde jeg en bredere forståelsesramme enn tidligere. Underveis i fortolkning og analyse har jeg lagt vekt på selvforståelsesnivået, det vil si at jeg har tatt hensyn til både informantens og forskerens forståelse av det frambrakte. Ved neste nivå i analysen, hvor informantenes utsagn ble løftet til et mer allmenngyldig nivå, erfarte jeg at min «insider»-posisjon bidro til å meningsfortolke informantenes utsagn. Tredje nivå er nivået hvor teorier blir brakt inn i fortolkningen for ytterligere å løfte og allmenngjøre utsagnene (Kvale \& Brinkmann, 2015).

\section{Gangen i analysen}

Jeg søkte etter mønstre i materialet for å kunne tematisere. Informantenes selvforståelse er søkt ivaretatt ved å løfte fram det erfaringsnære aspektet ved deres utsagn og handlinger. Samtidig er informantenes 
egentolkning av meningsinnholdet fortolket. Dette er i tråd med Martinussen, Nordahl-Pedersen og Nymo (2016, s. 218). Videre har jeg forsøkt å tolke informantens egen selvforståelse bredt ved å stille spørsmål til den transkriberte teksten. Teorier har bidratt til å løfte det jeg så og erfarte. Jeg har organisert drøftingskapitlet i ulike temaer som har gyldighet i datamaterialet, og i historiske fakta som jeg mener belyser problemstillingen. Egne erfaringer vil også tas med.

Temaer for drøftingen er forståelseshorisonter med underpunkter, kulturelle samværsmåter samt holdninger hos helsepersonell.

\section{Diskusjon}

\section{Forståelseshorisonter}

\section{Kopping og årelating}

Kopping og årelating er omtalt i NOU 1995: 6. Det trekkes paralleller til koppsuging i kinesisk medisin, som er en vanlig måte å behandle smertetilstander på. Kopping er også brukt mot krampetilstander (NOU 1995: 6, s. 110). I datatilfanget kommer det fram at kopping ( $g u h p p e t$ ) og årelating (vara luoitit) ${ }^{3}$ har vært mye brukt, både som helbredelse og for å forebygge sykdom (Nymo, 2003).

En av informantene sier at hun gjerne skulle ha prøvd kopping, slik hun erfarte at det ble gjort i hennes barndoms- og ungdomstid:

Ved kopping, kom det ut sånn der kaild væske, sånn væske, det der har æ sett.

Pappa og mamma, de va jo ... især pappa brukte mykje sånn, han fikk nån tel å gjøre det, men han gjorde det ikkje sjøl. (Nymo, 2003, s. 123)

Informanten ser tilbake i sitt liv og minnes at foreldrene, særlig faren, brukte kopping som behandling. Og hun minnes at det var kald væske som ble hentet ut ved behandlingen. I kinesisk medisin skiller man mellom kalde og varme sykdommer. Man har imidlertid ikke holdepunkter for at samer gjør det. Det tas imidlertid et forbehold om at mye gammel kunnskap kan ha gått tapt (NOU 1995: 6, s. 109). Av informantens utsagn ser 
man at hun snakker i retning av kalde og varme sykdommer. Formålet var å trekke ut «kaild og syk» væske med glass som på forhånd var oppvarmet.

En av informantene i Nymo (2003), en yngre kvinne, beretter at en av hennes nærmeste slektninger praktiserte denne kunsten. Det ble brukt rengjorte sennepsglass som ble sugd fast på det vonde kroppsområdet med vakuum. Huden ble først desinfisert. Deretter ble det «skutt hull» med en koppemaskin. Glasset ble sugd fast over hullet ved at det var en liten flamme i det. Det ble sugd ut blodvann i takt med en forestilling om at «den syke væsken» burde komme ut av kroppen. Når alt vannet som ble sett på som årsak til smerten, var hentet ut, og friskt blod kom til syne, ble glassene forløst fra huden. Det ble lest formular for blodstenging og mot betennelse, og plaster ble satt på (Nymo, 2003, s. 124).

Rent logisk kan man tenke seg at en slik behandling bidrar til at mye væske kommer ut fordi kapillærer og blodkar utvider seg ved varme. I dag drives det vakuumterapi med det siktemål at behandlingen skal gjenopprette balanse i kroppens blodsirkulasjon. Det settes vakuumkopper på spesifikke punkter i hud og underliggende vev. Hensikten er, ifølge de som utøver en slik terapi, å påvirke kroppens livsenergiflyt og blodsirkulasjon i hud og underliggende organer Vakuumterapi skal virke effektivt på smerter og også ha en forebyggende effekt. (NOU 1998: 21).

En annen informant forteller om en kombinasjon av kopping og årelating. Det gjelder hans mor: «Ho hadde jo gikt og va dårlig til beins. Som regel så søkte ho årelating og kopping. Det va ikkje bare årelating, det va kopping og. Og det hjalp» (Nymo, 2011, s. 236).

Kvinnen det berettes om, var plaget med både smerter og svimmelhet, noe som gjorde at hun hadde dårlig balanse. Ved svimmelhet ble «hodeblod» tatt ut, og det skjedde ved årelating i panna eller på handbaken, forteller informanten (Nymo, 2003, s. 125). Ved kopping og årelating framkom det en kunnskap som er forenelig med at blodåresystemet i menneskekroppen danner et nettverk som er forbundet med punkter på kroppen. Denne kunnskapsforståelsen har likheter med en forståelse om meridiansystemet i kinesisk medisin. Punkter på kroppens vener står i forbindelse med forskjellige organer og deres fysiologi. Meridianer i kinesisk medisin er energilinjer langs kroppen som er nøyaktig kartlagt 
og beskrevet (Legge, 1999). Akupunkturpunkter på kroppen kan ses som inngang til dypere energisirkulasjon. Ved at tradisjonsmedisineren leter etter en spesiell vene på handbaken, viser han at han har en forståelse om at det er forbindelse mellom hand og hode.

Vakuumkopping er bygd på forståelsen om at de spesifikke punkter i hud og underliggende vev som koppene settes på, er akupunkturmeridianer (NOU 1998:21). Samene har for eksempel pleid å årelate på fotryggen ved dårlig matlyst. Årelating på fotryggen skal svare til kinesernes ventrikkelkanal (magekanal), som med sin energibane går opp til ventrikkelen (magesekken) (NOU 1995: 6, s. 110). Etter kopping og årelating føler man seg bedre (Nymo, 2003, 2011).

For å antyde at praksisene jeg har gjengitt her, kan ha videre relevans for andre enn de som bor i markebygdene, nevner jeg at jeg i 2016 hadde faglig besøk av et barnebarn til en tidligere distriktslege i Skånland kommune, Ole Storstein, som hadde fortalt henne om samarbeid med tradisjonsmedisinerne. Virket til distriktslegen er skildret i en fagartikkel (Storstein, 1988). Barnebarnet arbeider med migrasjonshelse i Oslo og var interessert å høre om samiske helbredelsespraksiser. Jeg tok henne med til en tradisjonsmedisiner som praktiserer kopping og årelating. Tradisjonsmedisineren husket legen. Når Ole Storstein blir husket av tradisjonsmedisineren, som var datter av en tradisjonsmedisiner som var aktiv da Storstein virket som lege før andre verdenskrig, viser det at han hadde tillit hos befolkningen i markebygdene.

\section{Ubuden gjest}

Den eldre kvinnelige informanten som hadde vært alvorlig syk, og som jeg samtalte med for cirka ett år siden, hadde hatt kreft. Hun unngikk å benevne sykdommen ved navn, selv etter flere år. Hun gir sykdommen navnet «ubuden gjest» - en som trenger seg på. Hun sier at det å uttale ordet kreft er å gi sykdommen næring: «Det er best å tie. Det er lærdom fra barnsben av.» Forfatteren Rose-Marie Huuva kalte kreftsykdommen hun fikk, for galbma Rádná (kald kamerat) (Huuva, 1999). Huuva ga kreften et fiktivt navn, slik samene ga koppene under epidemien på 1700-180o-tallet (Sköld, 1998). Informantens praksis er forenelig med praksisen til Huuva, og til samene som Sköld forteller om. 
Sykdom som metafor kan forstås som at sykdommens medisinske perspektiv farges av et kulturelt og sosialt perspektiv (Sontag, 2010). Personlige erfaringer spiller inn, man forstår og forklarer ut fra det levde livet. På et av helsetreffene hvor en samisk lege hadde innledning om hjertesykdommer, fortalte en av deltakerne at han hadde fått «svære bivirkninger» av hjertemedisinen Selo-Zok (betablokkere). Han la fram fenomenet slik: «Ryggen min så verre ut enn om finnmarksmyggen hadde vore laus» (Nymo, 2011, s. 184).

Utbruddet av allergi framsettes som et bilde, og mannen forventer at alle tilstedeværende skal skjønne hvordan ryggen hans hadde sett ut. Meddeltakerne skjønner at han må ha hatt voldsom kløe. På helsetreffene blir det brukt metaforer for å beskrive kroppslige tilstander når temaet omhandler helse og sykdom. Det forutsettes at tilhørerne er kulturelt kompetente og kan fatte poenget. Dette er eksempler på at man ikke er direkte når man omtaler sykdom eller plager. Man unngår å snakke om sykdom (Bongo, 2012).

En annen informant fortalte at en gang han var hos legen, fikk han høre at han hadde høy blodprosent. Han hadde replisert slik: «den gamle maten ga mykje blod. Du kan takke den samiske maten for det, vi spis blodklubb to ganga i uka og veit dokker æ bydde dokteren blodklubb, men han ville ikkje ha det. Sa æ kuinne ta med neste gang i ei spann» (Nymo, 2011, s. 187).

Han fortalte at han tilbød å ta med seg et spann med gumba neste gang, slik at legen selv fikk bedømme matrettens kvalitet. En av de andre deltakerne sa at hun ikke trodde på hans fortelling om å ta gumbaen i et spann med til legen. Mannen repliserte: «Æ måtte no filme litt.»

Her ser vi eksempel på at mannen skjermer seg for informasjon om sykdommen, og han prøver å gi inntrykk av at han ville målbinde legen. Humor brukes ofte for å slippe å gå dypere inn i problemer og utfordringer (Nymo, 2003, 2011). Man vegrer seg for å ta innover seg sykdomsprat og forsøker å omdefinere sykdomsprat til noe morsomt. Det kan ses som å stenge ute en ubuden gjest. En lege som jeg arbeidet sammen med på medisinsk avdeling på sykehuset i Narvik, var opptatt av å føle seg fram til om pasienten var moden for dårlige nyheter. Han sa at han hadde lært i løpet av sin legegjerning at man ikke skulle trenge på med informasjon. 
I ettertid har jeg tenkt at denne legen tenkte helhetlig. Han ga pasienten tid og handlet personorientert.

I dagens medisinske behandling er det imidlertid slik at informasjon om sykdommen og dens behandling anses som svært viktig. Helsepersonelloven (2015) og pasient- og brukerrettighetsloven (2014) forplikter til det. Pasienten skal være informert for blant annet å kunne ta beslutninger. Det moderne helsevesenets praksiser kan støte mot kulturelle forståelseshorisonter. Mange ganger er det slik at jussen tar for stor plass i utøvelse av sykepleiefaget, og pasientens kulturelle ståsted ignoreres. Det reduserer trygghetsfølelsen fordi pasienten kan føle det som om det han har å si, får mindre betydning.

\section{Kulturelle samværsmåter}

En informant forteller at mor hans, som bodde i en omsorgsbolig på tettstedet i kommunen, var trist over at hun hadde måttet forlate hjemmet. Så traff hun en kvinne fra en annen markebygd, og de dannet et fellesskap. Så ble den andre kvinnen dårlig og måtte overflyttes til sykehjem. Moren ble «alene» og vantrivdes: «... Ho stoppa helt å fungere. Egentlig sku de ha flytta begge to. For sånn sett hadde det ikkje gjort noe om mor mi blei flytta» (Nymo, 2011, s. 148).

Mange eldre samer som må flytte fra hjemmet, føler seg fremmedgjort. Kulturelt betinget omgangstone, samværsformer og kommunikasjonsmåter er viktig i omsorgen for den samiske pasienten (Bongo, 1986). Relasjoner til mennesker og til hjemlige trakters landskap og natur er sterke og viser seg når folk eldes (Nymo \& Minde, 2014). Det betyr mye å føle seg hjemme i verden (Ragazzi, 1999).

Várdobáikis helsetreff er et sted hvor kulturelle samværsmåter forpleies. Eldre samer som har flyttet fra sine hjem og bor på for eksempel institusjoner på kommunenes tettsteder, møtes på helsetreffene. Også utflyttere til Harstad og Narvik deltar. «Det er viktig å kunne prate kjenning», sier en informant. Man får høre nytt, og man behøver ikke å forklare så mye, i og med at den andre vet hva det snakkes om. På helsetreffene kan dessuten samisk og norsk brukes om hverandre.

Forsamlinger i den læstadianske menigheten representerer et omsorgssystem (Nymo, 2011). Og det gjelder i særlig grad i forsamlinger hvor samisk språk kan brukes: 
Æ veit at no det va småsamlinge så kunne de preike på samisk, de va sikker på at det va folk som forsto. At det ikkje va nån som kom uten ifra. Da va det no bare folk i fra bygdene. (upublisert datamateriale (Nymo, 2011).

Med småsamlinger menes søndagssamlinger om Guds ord, og de gikk på omgang fra hus til hus. Informanten minnes disse, og man aner en lengsel etter å kunne bruke samisk. Både på helsetreffene og i læstadianske forsamlinger spiller det kulturelle inn. Ingar Kaldal ser på minner som kollektive, sosiale og kulturelle, og han sier at det i mange kulturer er naturlig å snakke om livet som del av et fellesskap, og å fortelle i vi form (Kaldal, 2016, s. 85). Dette praktiseres innenfor en kollektivistisk kultur. Kollektivisme er representativt for tradisjonelle samfunn, det vil si i førmoderne primærnæringssamfunn og i småskalasamfunn. I slike samfunn er menneskene avhengig av hverandre for at livet skal gå rundt. Eldre har sin tydelige plass i slike samfunn. Den kollektivistiske kulturens motstykke er individualistisk. Norsk kultur er preget av å være individualistisk, og den heller mot vestlig kulturorientering (Hanssen, 2014).

Samene har fått flere rettigheter, blant annet til å bruke samisk språk i møte med det offentlige, og de har fått plass i den norske grunnloven gjennom den såkalte sameparagrafen (Skogvang, u.å.). Det er et løft fra en historisk stigmaposisjon. Forskrifter til rammeplanen for helse- og sosialfagutdanninger er et skritt i samme retning. Med det følger en forventning om at det innenfor helsevesenet blir en bredere forståelse av samiske pasienters livsverden. Det innebærer blant annet å lage ramme rundt kollektivistiske samværsformer, for eksempel ved å åpne opp for pårørendes tilstedeværelse på helseinstitusjoner og være mindre rigid med hensyn til besøkstider. På rapport- og fagmøter bør pasienters trivsel og psykiske og åndelige behov drøftes.

\section{Holdninger blant helsepersonell}

Selv om forhold har endret seg og samisk kultur, språk og samfunnsliv har hatt et løft, kan samer oppleve stigmatiserende holdninger, En informant forteller:

«For det e mange som fortell til legen sin. For æ vet et tilfelle der en hadde saga sæ så forferdelig og blødde. Så va det til legen, men først va det nu å stoppe blodet. Og så fôr han til legen. Og legen spurte: «Har du blødd mykje? Nei, 
naboen stoppa det.» Legen spurte: «Har du hatt mykje verk?» «Nei, naboen tok det bort.» «Trur dåkker ennu på sånt», sa legen» Nymo, 2011, s. 259).

Legen - som representant for norsk helsevesen - generaliserer her samene ved å si «trur dokker ennu på sånt?». Det er nærliggende å tro at han tenker «oss og dem» - «vi norske og dere samer». Det er et skille som kan forstås som en etnisk grense (Mathisen, 1989) ${ }^{4}$. En etnisk grense kan defineres som en tankemessig konstruksjon, og den er ofte bygd opp om etniske kategoriseringer som kan være vanskelig å dekonstruere. Det man har fått innlært, sitter. Når så forhold endrer seg over tid og etniske kategoriseringer avtar, skjer det en dekonstruksjon av det tankemessige (Mathisen, 1989).

Mange eldre samer har opplevd sterke etniske kategoriseringer og har blitt stigmatisert som mindreverdige. De bærer forkroppsliggjorte minner med seg. Samer kan være sårbare og tolker ofte ting innenfor en etnisk grensekontekst. Dette kan vises i møter med helsepersonell. En eldre samekvinne i en markebygd hadde en syk ektefelle som ønsket å bo hjemme, ikke på sykehjem. Hun forteller: «En gang han va på sykehus så fikk æ beskjed no æ kom på sykehuset at han sku reise tel sykehjem i dag. Vi bei sjokkert, og på sykehuset sa de: 'Veit dokker ka dokker går tel?’»

Kvinnen hadde hjelp fra offentlig hjemmetjeneste til forpleining og omsorg av ektefellen. Hun ønsket ikke at mannen skulle bo under upersonlige forhold, som hun anså et sykehjem for å være. Det ble så mange fremmede rundt han, mente hun. Han ville komme langt fra slekt og venner og ville vantrives. Slektskap, både blodslekt og sideordnet, som nabofellesskap utgjør, har betydning for samene. Sideordnet slekt er rituell slekt (fadderskap), navnesøsken (gaibmi), næringsmessig slekt (siida-ordning) og geografisk, det vil si nabo- og bygdefellesskap (Henriksen, 2004). Slektskap fungerer som et viktig omsorgssystem i samisk kultur og tenkning (Nymo, 2011). Det er et kollektiv som opp gjennom tidene har dannet et sikkerhetsnettverk for omsorg, hjelp og støtte.

Kvinnen opplevde altså en krenkelse og mente at samiske verdier ble trampet på av hjemmetjenesten. Hun spurte om jeg noen ganger opplevde

4 Stein Mathisen er for øvrig fra Skånland, min barndomskommune, og tilhører den norske befolkningen. 
at vi samer er nedsett. Da jeg ikke svarte med en gang, sa hun: «Men før va vi i all fall nedsett, og kofør ville de ha han på sykehjem?» Hun tolket at hjemmetjenesten ønsket at han flyttet til sykehjem fordi de mente at hjemmet hans ikke var egnet for ivaretakelse av han. Vi ser at samer bærer med seg historiske krenkelser, og det gir utslag ved gitte anledninger. Man tolker i historisk kontekst.

Ellen Idivuoma (2015) mener at sykepleierutdanningene må legge til rette for å bevisstgjøre studenter om at pasienter fra andre kulturer enn de vestlige, har behov som må løftes fram som individuelle, grunnleggende behov, og at det må legges til rette for en pasientsentrert omsorgsmodell. Ramsden (1994) har påpekt at så lenge helsevesenets aktører glemmer at de er i en maktposisjon overfor maoriene som pasienter, finnes det ikke en forsvarlig sykepleie. Man må strebe etter å være kulturelt sensitiv, og erkjenne at det eksisterer forskjeller. Sykepleieren bør reflektere over at egen livserfaring og virkelighetsoppfatning kan ha betydning for synet på den andre. Pasienten må være med på å definere sykepleien (Ramsden, 1994). Brukermedvirkning som viktig i sykepleie ble tidlig betont av Ramsden (1994).

Helsedirektoratet inviterte i april 2017 til dialogmøte i Tromsø for å få innspill til videreføring av utviklingssenter for sykehjem og hjemmetjenester (USHT) til den samiske befolkningen, og det ble av deltakerne bedt om mer forskning. Jeg deltok, og jeg undret meg om vi trenger mer forskning. Er det kanskje uvilje mot å sette seg inn i forskningen som er gjort, og mot å implementere den slik at den nyttiggjøres i praksisutøvelsen? Kanskje lærere og undervisere ved helse- og sosialfagutdanninger bør vise større interesse for å sette seg inn i hva det innebærer å yte trygg sykepleie til samiske pasienter? Eller må det jobbes for å dekonstruere den etniske grensen, slik at nye holdninger tar plass? Først da vil vi få sykepleie som hviler på akademisk grunn.

\section{Avslutning}

Den samiske pasienten skal møtes på en verdig måte i helsevesenet, og hun eller han har rettslig beskyttelse for at kultur og språk skal bli imøtekommet. Utdanningsenhetene må ta dette innover seg og styrke kompetansen 
blant lærerstaben ved konsekvent å implementere forskning i praksisutøvelsen. Det er ikke nok at kandidaten skal kjenne til samers rettigheter, og ha kunnskap om og forståelse for samenes status som urfolk, slik det står i Forskrift om felles rammeplan for helse- og sosialfagutdanninger (2017). Det må utdannes sykepleiere som er sensitive og blir var forskjeller, og som dernest gjør en selvrefleksjon og blir klar over at hun eller han bærer med seg sin egen livserfaring og virkelighetsoppfatning. Hun eller han bør reflektere over hvilken virkning egne forståelseshorisonter om helse og sykdom kan ha på den samiske pasienten. Som helsearbeider bør en lytte til pasienten og prøve å forstå hennes eller hans forståelser. Brukermedvirkning legger opp til at pasientens eget kunnskapsgrunnlag vil vektlegges i utforming av sykepleietiltak. Det vil trygge pasienten i samhandling med «det fremmede» - det medisinske systemet.

\section{Referanser}

Bongo, B. (1986). Sykepleie som mellommenneskelig aspekt. Hva betyr kulturell bakgrunn og identitet i utøvelse av god sykepleie? Sámi medica: Áigecála. s. 19-22.

Bongo, B. A. (2002). «Hva er en bøerer?» Belysning om «en» måte å forstå psykiske lidelser på i den samiske kulturen (Hovedoppgave). Universitetet i Tromsø, Tromsø.

Bongo, B. A. (2012). «Samer snakker ikke om helse og sykdom». Samisk forståelseshorisont og kommunikasjon om helse og sykdom. En kvalitativ undersøkelse i samisk kultur (Doktoravhandling). Universitetet i Tromsø, Tromsø.

Bullington, J. (2004). Den objective kroppen och den levda kroppen i behandlingsrummet. I S. O. Lauritzen, F. Svenaeus \& A.-C. Jonsson (Red.), När människan möter medicinen. Livsvärldens och berättelsens betydelse for förståelsen av sjukdom och medisinsk teknologi (s. 49-68). Stockholm: Carlsson.

Christensen, O. (1997). Diskriminering og rasisme. I T. H. Eriksen (Red.), Flerkulturell forståelse (s. 90-107). Oslo: Tano Aschehoug.

Eidheim, H. \& Stordahl, V. (Red.) (1998). Kulturmøte og terapi i Sápmi. Karasjok: Davvi Girji.

Finnmarkssykehuset. (u.å.). SANKS Samisk nasjonal kompetansetjeneste - psykisk helsevern og rus. Hentet 24. september 2019 fra https://finnmarkssykehuset.no/ fag-og-forskning/sanks

Forsberg, A. (2016). Omvårdnad på akademisk grund. Att utvecklas och ta ansvar. Stockholm: Natur \& Kultur.

Forskrift om felles rammeplan for helse- og sosialfagutdanninger (FOR-2017-09-061353). Hentet fra https://lovdata.no/dokument/SF/forskrift/2017-09-06-1353 
Foss, I. C. \& Ellefsen, B. (2004). De utydelige overtramp? Etiske utfordringer ved kvalitative. studier. Vård i Norden, 24(3), 48-51.

Fossåskaret, E. (2007). Samfunnsforskning og solidaritetskamp. I T. H. Aase \& E. Fossåsskaret (Red.), Skapte virkeligheter. Om produksjon og tolkning av kvalitative data (s. 84-110). Oslo: Universitetsforlaget.

Fugelli, P. (1986). Skjult helsebehov blant samer? Sàmi medica, 3, 43-53.

Fugelsnes, E. (2016, 23. juni). Samene har ofte ikke kjent seg igjen i forskningsresultatene. Forskning.no. Hentet 24. september 2019 fra https:// forskning.no/partner-de-nasjonale-forskningsetiske-komiteene-forskningsetikk/ samene-har-ofte-ikke-kjent-seg-igjen-i-forskningsresultatene/412215

Gadamer H.-G. (1989). Truth and method (2. utg.). New York: Continuum.

Grimen, H. (2004). Holisme og reduksjonisme. I P. Nortvedt \& H. Grimen (Red.), Sensibilitet og refleksjon. Filosofi og vitenskapsteori for helsefag (s. 125-140). Oslo: Gyldendal Akademisk.

Hamran, T. \& Blix, B. H. (2015). Helse- og omsorgstjenester til samiske eldre (Temahefte). Tønsberg: Aldring og helse.

Hanssen, I. (2014). Etniske minoriteter. I M. Kirkevold, K. Brodtkorb \& A. H. Ranhoff (Red.), Geriatrisk sykepleie. God omsorg til den gamle pasienten (kap. 3). Oslo: Gyldendal Akademisk.

Hansen, K. L. (2015). Ethnic discrimination and health: The relationship between experienced ethnic discrimination and multiple health domains in Norway's rural Sami population. International Journal of Circumpolar Health, 74(1). https:// doi.org/10.3402/ijch.v74.25125

Heidegger, M. (2007). Voren og tid. Oslo: Pax Forlag.

Helsepersonelloven. (1999). Lov om helsepersonell m.v. (LOV-1999-07-02-64). Hentet fra https://lovdata.no/dokument/NL/lov/1999-07-02-64

Henriksen, J. E. (2004). Den samiske storfamilien i et nettverksperspektiv. I I. M. Tronvoll, A. Moe \& J. E. Henriksen (Red.), Hjelp i kontekst: Praksis, refleksjon og forskning (s. 40-59). Otta: Idut.

Hjortfors, L.-M. (2012). Släktbildens baksida (Berajgåva nievrep bielle). I L. M. Andreassen \& L. M. Skarvik (Red.), Bårjas. Drag: Diedalasj Àiggetjála Árran julevsáme guovdátjis. Populorvitenskapelig tidsskrift fra Árran. s. 48-58.

Huuva, R.-M. (1999). Kall Kamrat. Kautokeino: DAT.

Hætta, A.-K. (2010). Secret knowledge: the management and transformation of traditional healing knowledge in the Marka Sámi villages (Masteroppgave). Universitetet i Tromsø, Tromsø.

Idivuoma, E. (2015). Sykepleie til eldre pasienter med etnisk minoritetsbakgrunn på sykehjem. Hva skal til for at sykepleiere skal oppleve seg faglig trygg i møte med eldre pasienter med etnisk minoritetsbakgrunn på sykehjem? (Masteroppgave). Universitetet i Tromsø, Tromsø. 
Kaldal, I. (2016). Minner som prosesser - i sosial og kulturhistorie. Oslo: Cappelen Damm Akademisk.

Kassah, B. L. L, Nordahl-Pedersen, H. \& Tønnessen, S. (2014). Vilkår for samhandling og et helhetlig pasientperspektiv i helse- og omsorgstjenestene. I B. L. L. Kassah, W.-A. Tingvoll \& K. W. Kassah (Red.), Samhandlingsreformen under lupen: Kvalitet, organisering og makt i helse- og omsorgstjenestene. Bergen: Fagbokforlaget.

Kjølaas, P. O. (1996). Bibelen på samisk. En bok om samisk bibeloversttelse (2. utg). Oslo: Det norske bibelselskap.

Kristoffersen, N. J. (2016). Sykepleie - kunnskapsgrunnlag og kompetanseutvikling. I N. J. Kristoffersen, F. Nortvedt, E.-A. Skaug \& G. H. Grimsbø (Red.), Grunnleggende sykepleie. Pasientfenomener, samfunn og mestring (Bd. 1, s. 139-185). Oslo: Gyldendal Akademisk.

Kvale, S. \& Brinkmann, S. (2015). Det kvalitative forskningsintervju (3. utg.). Oslo: Gyldendal.

Kyllingstad, J. R. (2004). Kortskaller og langskaller: Fysisk antropologi i Norge og striden om det nordiske herremennesket. Oslo: Scandinavian Academic Press.

Larsen, A. I. L (2018). Mapping the experience and use of traditional healing in Northern Norway. Among conventional health care providers, users and traditional healers (Doktoravhandling). Universitetet i Tromsø, Tromsø.

Larsen, L. S. S. (2017). Speaking in behalf of the person with dementia in home-based care. A qualitative study of collaboration between formal and family caregivers in Sami and Norwegian municipalities (Doktoravhandling). Universitetet i Tromsø, Tromsø.

Lassenius, E. \& Severinsson, E. (Red.). (2014). Hermeneutik $i$ vårdpraxis. Det nära, det flyktiga, det dolda. Malmö: Gleerup.

Legge, D. (1999). Acupuncture points and meridians. Sydney: Sydney College Press. Martinsen, K. (2000). Øyet og kallet. Bergen: Fagbokforlaget.

Martinussen, I. S. Nordahl-Pedersen, H. \& Nymo, R. (2016). Bruk av private helseog omsorgstjenester. I B. L. L. Kassah, W.-A. Tingvoll \& H. Nordahl-Pedersen (Red.), Forebyggende helsearbeid - sykepleie i kommunal helse- og omsorgstjeneste (s. 213-229). Oslo: Gyldendal Akademisk.

Mathisen, S. R. (1989). Den etniske grensen mellom nordmenn og samer. Norveg. Folkelivsgransking, 32.

Mathisen, S. R. (200o). Folkemedisinen i Nord-Norge. Kulturelt fellesskap og etniske kilder. I I. Altern \& G.-T. Minde (Red.), Samisk folkemedisin i dagens Norge (rapport fra seminar holdt i 1998). Tromsø: Senter for samiske studier / Sámi dutkamiid guovddás, Universitetet i Tromsø. 
Meistad, T. (1999). Kristendommens historie i Nord-Norge gjennom tusen år. I Ø. Danielsen (Red.), Den kircke har noget at sige (Petter Dass). Dåp og kristning $i$ 1000 år. Festskrift for kirken i Hålogaland 999-1999 (s. 23-62). Alta.

Merleau-Ponty, M. (1994). Kroppens fenomenologi. Oslo: Pax Forlag.

Myrvoll, M. (2008). Forestillinger og praksiser knyttet til døden. I B. Evjen \& L.-I. Hansen (Red.), Nordlands kulturelle mangfold. Etniske relasjoner i historisk perspektiv (s. 273-303). Oslo: Pax Forlag.

Nakata, M. (2007). Disciplining the savages, savaging the disciplines. Canberra: Aboriginal Studies Press.

NOU 1995: 6. (1995). Plan for helse- og sosialtjenester til den samiske befolkning $i$ Norge. Hentet fra https://www.regjeringen.no.

NOU 1998:21. (1998). Alternativ medisin. Hentet fra https://www.regjeringen.no.

Nymo, R. (2003). «Har løst å kle på sa kofte, men tør ikkje og vil ikkje.» En studie av fornorskning, identitet og kropp blant samer i Ofoten og Sør-Troms (Hovedfagsoppgave). Universitetet i Tromsø, Tromsø.

Nymo, R. (2011). Helseomsorgssystemer i samiske markebygder i Nordre Nordland og Sør-Troms. Praksiser i hverdagslivet. «En ska ikkje gje soe over og en ska ta tida til hjelp» (Doktoravhandling). Universitetet i Tromsø, Tromsø.

Nymo, R. \& Minde, G-T. (2014). Makt og kvalitet - hvordan urfolks- og minoritetspasientenes kulturelle erfaring og kunnskap trer fram i møte med helsepersonell i en rehabiliteringsprosess. I B. L. L. Kassah, W.-A. Tingvoll \& K. A. Kassah (Red.), Samhandlingsreformen under lupen: kvalitet, organisering og makt i helse- og omsorgstjenestene (s. 169-186). Bergen: Fagbokforlaget.

Nystad, T., Melhus, M. \& Lund, E. (2006). Samisktalende er mindre fornøyd med legetjenestene. Tidsskriftet for Den norsk legeforening, 126(6), 738-740.

Pasient- og brukerrettighetsloven. (1999). Lov om pasient- og brukerrettigheter (LOV1999-07-02-63). Hentet fra https://lovdata.no/dokument/NL/lov/1999-07-02-63

Ragazzi, R. (Regissør). (1999). Else hjemme i verden (Norsk dokumentarfilm). Hentet 7. august 2018 fra http://www.filmfront.no/utgivelse/3618/else-hjemme-i-verden

Ramsden, I. (1994). Own the past and create the future. Foredrag til Te Hui Whakapumau ved Maori Development Conference, Massey University, Palmerston North.

Senter for samisk helseforskning (SSHF). (u.å.). Universitetet i Tromsø. Hentet 24. september 2019 fra https://uit.no/om/enhet/forsiden?p_dimension_id=88115

Sköld, P. (1998). Escape from catastrophe: The Saami’s experience with smallpox in eighteenth- and early-nineteenth-century Sweden. Social Science History 21(1), 1-25. https://doi.org/10.2307/1171454

Skogvang, S. F (u.å.). Sameparagrafen. Hentet 13. januar 2020 fra https://snl.no/ Sameparagrafen 
Sontag, S. (2010). Sykdom som metafor. Et essay om holdninger til sykdom og død $i$ vårt samfunn. Oslo: Bokklubben.

Sosial- og helsedepartementet. (2001). Mangfold og likeverd. Regjeringens handlingsplan for helse- og sosialtjenester til den samiske befolkningen i Norge 2002-2005 (I-1046 B). Hentet fra https://www.regjeringen.no

Stordahl, V. (1997). Samene: Fra «lavtstaaende race» til urbefolkning. I T. H. Eriksen (Red.), Flerkulturell forståelse (s. 139-152). Oslo: Tano Aschehoug.

Storstein, O. (1988). Lege for 50 år siden - eller vel så det. Tidsskriftet Den Norske Loegeforening, 108, 34-36.

Sørly, R., Nygaard, V. \& Mathisen, V. (2018). Brukermedvirkning i samiske perspektiver og kontekst (Prosjekt). Bergen: NORCE Norwegian Research Centre.

Sørly, R. (2019). Det store spørsmålet - hvilken plass har fortellinger i psykisk helsearbeid? Tidsskriftet Dialog Seprep, 4, 6-21.

Thornquist, E. (2003). Vitenskapsfilosofi og vitenskapsteori for helsefag. Bergen: Fagbokforlaget.

Tronvoll, I. M., Moe, A. \& Henriksen, J. E. (Red.). (2004). Hjelp i kontekst: Praksis, refleksjon og forsking. Otta: Iđut.

Wifstad, Å. (1994). Møtet med Den Andre. Tidsskriftet Den Norske Loegeforening, 114(30). 


\title{
Kunnskap om barns kollektive ansvarserfaringer og implikasjoner for tjenesteutøvelse i barnevernet
}

\author{
Katrine Høgmo, Kwesi Alexander Kassah og \\ Bente Lilljan Lind Kassah \\ UiT Norges arktiske universitet
}

\begin{abstract}
A major goal of the Child Welfare Services is to provide the best possible support to children in challenging life situations, including cross-cultural children, in Norway. However, there is inadequate knowledge about cross-cultural children's responsibility taking and its implications for service delivery in Norwegian municipalities. This chapter discusses the importance of increased knowledge of the responsibility-taking practices of cross-cultural children for Municipal Child Welfare Service workers' service delivery. The authors based the chapter on literature from studies on responsibility-taking experiences of children from Peru, Norway and other countries outside Europe. The literature indicates that many children have responsibilities to work and contribute to the sustenance of their families. Often, the children experienced feelings of identity, belonging and pride in mastering work roles. It is, therefore, difficult to understand the practices of these children as destructive parentification. On the contrary, the expectation that children provide for the upkeep of their families often attracts the destructive parentification label in European countries. Also, we argue that nuanced understanding of cross-cultural children's responsibility-taking practices and identities may equip Child Welfare Services workers with competence that may enable them to provide the best possible support to cross-cultural children in Norway.
\end{abstract}

Keywords: Child Welfare Services, cross-cultural children, responsibility taking, cultural competence, identity

Sitering av denne artikkelen: Høgmo, K., Kassah, K. A. \& Kassah, B. L. L. (2020). Kunnskap om barns kollektive ansvarserfaringer og implikasjoner for tjenesteutøvelse i barnevernet. I B. L. L. Kassah, H. Nordahl-Pedersen \& W.-A. Tingvoll (Red.), Handlingsrom for profesjonalisert velferd: Kommunale tjenester for helse, omsorg og barnevern (Kap. 11, s. 243-262). Oslo: Cappelen Damm Akademisk. https:// doi.org/10.23865/noasp.114.ch11

Lisens: CC-BY 4.o. 


\section{Introduksjon}

Et viktig mål for barnevernet i Norge er å ivareta barnas beste i tjenesteutøvelsen, da også barn med krysskulturell bakgrunn, som befinner seg i utfordrende livssituasjoner. Det er imidlertid begrenset kunnskap om krysskulturelle barns ansvarstaking, og om hvordan begrenset kunnskap virker inn på tjenesteutøvelsen i barnevernet. I dette kapitlet belyses hvordan økt kunnskap om krysskulturelle barns ansvarserfaringer kan ha betydning for kommunalt barnevernansatte som jobber for å sikre barnas beste. I 2020 er det 54592 barn og unge som har barneverntiltak i Norge (Statistisk sentralbyrå, 2020), noe som tyder på at det er mange utsatte barn som er i kontakt med norsk barnevern. Barn som opplever risiko knyttet til oppvekstsvilkår, skole, psykisk helse, rus, vold eller annet, betraktes som utsatte barn (NOU 2009: 22). Mange barn med krysskulturell barndom kan betraktes som å befinne seg innenfor gruppen utsatte barn. Ifølge Salole (2018) foreligger det begrenset forskning om krysskulturelle utfordringer og spørsmål. Barns kollektive ansvarserfaringer er imidlertid komplekse og må forstås kontekstuelt og undersøkes i dialog med det enkelte barnet og dets familie (jf. Ulvik, 2019).

Barn defineres her som personer under 18 år (barnevernloven, 1992, $\$ 1-3)$. Barn som vokser opp med regelmessig innflytelse fra flere kulturer, omtales som krysskulturelle barn (Salole, 2018). Temaet er viktig, fordi et av barnevernets grunnprinsipper er at tjenesteutøvelsen skal være til barnets beste (barnevernloven, 1992). Barnas beste er en rettighet som er gjennomgående i barneretten (Høstmælingen, Kjørholt \& Sandberg 2020). Det er ikke alltid åpenbart hva som er barnas beste, da det kan defineres forskjellig (Thomas, 2005, referert i Grønvold \& Støre, 2010). Hvordan ansatte forstår og ivaretar krysskulturelle barns beste, avhenger av de ansattes kompetanse, og av hvilke muligheter de ser i handlingsrommet (se kapittel 1) for tjenesteutøvelse. Ifølge Engebrigtsen (2020) er det avgjørende å være bevisst at det ikke finnes et entydig svar på hva som er barnets beste når det gjelder krysskulturelle barns ansvarstaking overfor familiens opprettholdelse.

I Norge er det et statlig og et kommunalt barnevern, og i dette kapitlet rettes søkelyset mot den kommunale barneverntjenesten. Det er 295 
kommunale barneverntjenester som er ulikt organisert, og som omfatter 425 kommuner (A. Proff, G. Proff, Toresen \& Steinrem, 2018). Barnevernet som institusjon skal sikre at barn og unge som lever under forhold som kan skade deres helse og utvikling, får nødvendig hjelp og omsorg til rett tid (barnevernloven, 1992, $\$ 1-1$ ). Nasjonale myndigheter legger vekt på et kunnskapsbasert barnevern (Skivenes, 2018). Det innebærer at barns og foreldres kunnskap, forskning samt praksiskunnskap skal danne grunnlag for utvikling av tiltak i barnevernet. Den kommunale barneverntjenesten har ansvar for forebyggende arbeid, utredning og undersøkelser som inkluderer kartlegging av barnet og dets situasjon. Tjenesten skal også gi råd og veiledning, fatte vedtak om frivillige hjelpetiltak, treffe midlertidige vedtak i akuttsituasjoner, forberede tvangssaker for behandling i fylkesnemnda for barnevern og sosiale saker og godkjenne og føre tilsyn med fosterhjem. Den kommunale barneverntjenesten skal iverksette tiltak og følge opp barn som mottar hjelp fra barnevernet, inkludert barn som er plassert utenfor hjemmet (Barne-, ungdoms- og familiedirektoratet [Bufdir], 2019; Bufdir, 2020). Barneverntjenestene har også ansvar for ettervern av unge opptil 25 år som har hatt oppfølging fra barnevernet, og som fortsatt har behov for det (endringslov til barnevernloven, 2020). Enslige mindreårige flyktninger har ofte oppfølging fra kommunale barneverntjenester (Integreringsog mangfoldsdirektoratet [IMDI], 2018). Det kommunale barnevernet yter tjenester til barn og familier i utsatte livssituasjoner, deriblant også barn og unge med flerkulturell bakgrunn. Det er behov for økt kompetanse på alle områder i det kommunale barnevernet, også når det gjelder tjenesteutøvelse knyttet til barn med minoritetsbakgrunn (Bufdir, 2020). Hensikten med kapitlet er å belyse at kunnskap om - og forståelse av - barns kollektive ansvarserfaringer kan bidra til å styrke barnevernets kunnskapsbaserte tjenesteutøvelse.

Datagrunnlaget for diskusjonen er hentet fra litteratur om barns kollektive ansvarserfaringer, både utenfor Europa og blant krysskulturelle barn i Norge. Videre i kapitlet presenteres teoretisk rammeverk, metoder for datainnsamling, presentasjon av data og drøfting av funnene. Til sist gis en oppsummering av kapitlet. 


\section{Teoretiske ressurser}

Her presenteres relevante teoretiske begreper som kan gi en forståelse av barns kollektive ansvarserfaringer og barnevernansattes handlingsrom i møte med krysskulturelle barn og deres erfaringer. Det redegjøres for kulturkompetanse, barns ansvarserfaring, parentifisering og handlingsrom.

\section{Kulturkompetanse}

For å forstå begrepet kulturkompetanse er det først nødvendig å definere kulturbegrepet. Kultur forstås her som «de ferdigheter, oppfatninger og væremåter personer har tilegnet seg som medlemmer av et samfunn» (Eriksen, 1998, s. 24). Kultur er ikke statisk, men skapes kontinuerlig i en dynamisk prosess gjennom menneskers samhandling og etablering av meningsfelleskap (Eriksen, 1998; Hastrup, 1995; Eriksen \& Sajjad, 2015). Begrepet kulturkompetanse er omdiskutert, og det argumenteres for at kulturkompetanse forutsetter holdninger, kunnskap og ferdigheter (Saus, Salamonsen, Douglas, Hansen \& Thode, 2018). Videre påpeker forfatterne at kulturell kompetanse ikke kan gis som standardisert opplæring, men krever erfaring, tilpasning til det enkelte barn og dets familie samt stadig kritisk refleksjon. Derfor er det viktig for barnevernansatte å jobbe kontinuerlig med holdninger, kunnskap og ferdigheter på individuelt, gruppe- og organisasjonsnivå gjennom hele yrkeslivet (Saus et al., 2018). Kulturell kompetanse innebærer at barnevernansatte er bevisst at vi har ulike kulturelle referanserammer, og at de søker å få innsyn i disse ved å etterspørre brukernes egne erfaringer. Det innebærer videre at barnevernansatte prioriterer å involvere brukerne i beslutninger som angår dem, samt at innsikten de får gjennom dette, brukes aktivt i de ansattes vurderinger, beslutninger og fremgangsmåter (Saus, 2006; McPhatter, 1997; Boine 2010). Det er viktig å ha bevissthet om ulike kulturelle referanserammer samtidig som man vurderer hvordan disse henger sammen med andre sosiale og økonomiske forhold, som migrasjon, flukt, levekår og minoritetsrelaterte faktorer (Engebrigtsen, 2017; Berg et al., 2017; Fylkesnes \& Paulsen, 2019). Kulturkompetanse for dem som jobber innenfor barnevernet, innebærer i stor grad også en forståelse av hvorfor det er 
viktig at barn blir anerkjent for den de erfarer at de er, for deres identitet (Lauritsen \& Berg, 2019). Jenkins (2014, s. 19) definerer identitet som «vår forståelse av hvem vi er og hvem andre mennesker er, og, gjensidig, andre menneskers forståelse av seg selv og av andre (som inkluderer oss)». Identitet forstås i dette kapitlet som noe grunnleggende relasjonelt, det vil si at vår erfaring av oss selv i stor grad påvirkes av det sosiale miljøet vi befinner oss $i, o g$ av den tilbakemeldingen vi får fra betydningsfulle andre (jf. Jenkins, 2014). Grunnleggende verdier og forståelsesmåter kan variere mellom ulike sosiokulturelle grupper og er også en del av barns og unges identitet (Salole, 2018). Dette er spesielt viktig i barnevernets arbeid med krysskulturelle barn.

\section{Barns kollektive ansvarserfaringer}

Kollektive ansvarserfaringer kan forstås som erfaringer knyttet til menneskers plikter i livsløpet. I den vestlige delen av verden blir barnerollen i dag ofte forbundet med lek og læring, mens voksenrollen først og fremst forbindes med arbeid og produktivitet (Montgomery, 2008; Abebe \& Bessell, 2011). Dette skillet i ansvar mellom barn og voksne er fundert i en bestemt historisk, økonomisk og kulturell kontekst (James, Jenks \& Prout 1999; Schrumpf, 2007).

Barn i Norge forventes gradvis å lære og bli et selvstendig uavhengig individ som tar ansvar for egen læring og individuelle utvikling (Lidén, 2017; Erstad, 2015; Engebrigtsen \& Fuglerud, 2009; Engebrigtsen, 2020; Salole, 2018). FNs barnekonvensjon (De forente nasjoner, 1989; FN-sambandet, 2019) og dominerende globale politiske diskurser om den ideelle barndommen setter utdanning fremfor arbeid og konsum over produktivitet (Abebe \& Bessell, 2011). I noen samfunn innebærer barnerollen arbeid og medansvar for familiens opprettholdelse (Abebe, Waters \& Skelton, 2017). Ifølge International Labour Office (ILO) var 152 millioner barn i arbeid på verdensbasis i perioden 2012-2016 (ILO, 2017). Mesteparten av barns arbeid foregår innad i familieenheten (ILO, 2017). De fleste barn arbeider på familiegårder med jordbruk eller i familiebedrifter, og familiene er ofte avhengig av barnas arbeidsbidrag for å klare seg (ILO, 2017). Mye av det arbeidet som barn utfører på verdensbasis, 
kan ikke regnes som utnyttende. Barn arbeider ofte side om side med andre i familien, med arbeidsoppgaver som er tilpasset alder og fysikk. Arbeidet kan ofte fungere utdannende slik at barn får relevante erfaringer for sitt senere liv, samtidig som de får en plass og tilhørighet i samfunnet (Abebe et al., 2017; Aufseeser, Bourdillon, Carothers \& Lecoufle, 2018).

Flere stiller spørsmål ved hvordan vi kan skille arbeid, lek og læring, og de argumenterer for at disse svært ofte henger sammen (Montgomery, 2008; Punch, 2003; Høgmo, 2012; Abebe et al., 2017). Barns arbeidsdeltakelse kan i mange tilfeller gi et barn eller en familie inntekt som gjør det mulig å betale for barnets utdanning (Morrow, 2017), og barnet får dermed mulighet til å forbedre egen situasjon (Aufseeser et al., 2018). Andre ansvarsoppgaver som husarbeid, matlaging og omsorgsoppgaver som pass og stell av yngre eller eldre familiemedlemmer kan også være avgjørende for barns og deres familiers velferd (Abebe et al., 2017). Blant norske barn kan vi også finne eksempler på kollektive ansvarserfaringer (Jávo, 2010) som utfordrer ideer om en barndom preget av lite ansvar for familiens ve og vel. Det er imidlertid lang tradisjon for at barn tar ansvar og arbeider som tungeskjærere under lofotfisket (Johansen, Juell \& Lysvold, 2019). Lavinntektsfamilier og aleneforeldre vil kanskje ha større behov for at barn hjelper til med ulike oppgaver enn andre familier, uavhengig av kulturell bakgrunn. Boine (2010) hevder at enkelte samiske barn gradvis oppdras til å få ansvar tidligere enn det som er vanlig blant den norske majoritetsbefolkningen, men det finnes generelt lite nyere forskning på samiske barns ansvarserfaringer (Saus et al., 2018).

A delta i arbeid og ulike ansvarsoppgaver oppleves ikke alltid som negativt. «Work has also a psychological significance: it is an essential source of identity, which provides children and young people with confidence, relative independence, and feelings of self-worth» (Abebe et al., 2017, s. ix). Det er viktig å nyansere barns ansvarstaking, at man verken svartmaler eller romantiserer, men at man viser kompleksiteten ved å ta utgangspunkt i konkrete barns liv og utforske deres kollektive ansvarserfaringer sammen med dem (Abebe et al., 2017; Aufseeser et al., 2018). 


\section{Parentifisering}

Parentifisering er betegnelsen på en form for omsorgssvikt der barn inngår i omsorgsroller overfor sine omsorgspersoner. Barnets kulturbakgrunn er et av flere momenter som må vektlegges i vurderingen av om parentifisering er tilfelle. Kvello (2015, s. 214) definerer parentifisering slik: «Barnet trekkes inn i en voksenverden det ikke er modent for, eller gis større belastninger enn det som er kulturelt vanlig eller ansett som forsvarlig/ønskelig ut fra alder og modenhet.» Haugland (2006, s. 212) oversetter Valleau, Bergner og Hortons (1995, referert i Haugland, 2006) definisjon på følgende måte: «Parentifisering er et mønster av familieinteraksjon hvor barn og ungdom tildeles roller og ansvar som innenfor deres kultur normalt utføres av voksne omsorgsgivere.» Ifølge Jurkovich (1997) innebærer adaptiv parentifisering at barn får omfattende omsorgsoppgaver i familien, men samtidig får barnet støtte fra andre. Arbeidsoppgavene kan ha avgrenset varighet. Adaptiv parentifisering kan ha positive konsekvenser som økt selvfølelse og kompetanse, samt økt empati og resiliens (Haugland, 2006). Parentifisering betraktes som destruktiv når arbeidsoppgavene ikke står i forhold til alder og modenhet, og når barna ikke får støtte eller anerkjennelse for sin innsats. Destruktiv parentifisering innebærer at generasjonsgrenser og kulturelt definerte regler som gjelder roller, rettigheter og forpliktelser mellom barn og foreldre, smuldres opp. Det kan være utfordrende for barnevernansatte å vurdere hvorvidt ansvaret krysskulturelle barn i Norge har, er eller ikke er en urimelig byrde (Kvello, 2015).

\section{Handlingsrom}

Begrepet handlingsrom, «managerial discretion» eller «latitude of action», omhandler ansvars- og myndighetsområder i en organisasjon (se kapittel 1). Begrepet viser til «rom for handling», det vil si rommet mellom krav og begrensninger som virker styrende på de valgene som foretas (Stewart, 1982). I Norge har flere benyttet begrepet for å synliggjøre muligheter og begrensninger for handling i organisatoriske kontekster (Strand, 2007; Espedal, 2008; Espedal \& Kvitastein, 2014; Andersen, Moldenæs \& Torsteinsen, 2017). Ifølge Hambrick og Finkelstein (1987) 
kan et stort handlingsrom påvirke strategiske valg, og handlingsrommet har slik betydning for en organisasjons resultater. I tråd med Hambrick og Finkelstein (1987) sin forståelse av begrepet kan handlingsrommet påvirke barnevernansattes mulighet til å forme barneverntjenestens mål og fremgangsmåter. Ifølge Schönfelder, Andersen og Kane (2018) skapes handlingsrommet kontinuerlig i krysningen mellom ulike faktorer. Forfatterne påpeker at kunnskap kan være en faktor som skaper muligheter og begrensninger for hva man kan eller ikke kan gjøre. Ulvik (2019) hevder at ulike faglige perspektiver og forståelser av barn har ulike konsekvenser for tjenesteyteres handlingsrom. Kunnskap i form av «selvfølgelige» forståelser av barn kan stenge dørene for mer hensiktsmessige fremgangsmåter i møte med enkeltbarn. Begrepet handlingsrom forstås i dette kapitlet som barnevernansattes mulighet til å gjøre handlingsvalg i rommet mellom begrensninger og krav i møte med krysskulturelle barn.

\section{Metode}

Forskningslitteratur fra ulike kilder er benyttet i dette kapitlet. Empiriske funn fra et seks måneder langt kvalitativt etnografisk feltarbeid om barns kollektive ansvarserfaringer i landsbyen Llaqta danner grunnlag for kapitlet. Llaqta er et fiktivt navn på en landsby i de peruanske Andesfjellene bestående av rundt hundre hushold med fattige bønder. Feltarbeidet ble gjennomført av førsteforfatter i forbindelse med hennes masteroppgave i sosialantropologi (Høgmo, 2012). Hoveddeltakerne i studien var barn mellom tre og tolv år. Det ble også gjennomført semistrukturerte intervjuer med totalt seksten foreldre, fire lærere og en barnehagebestyrer.

Gjennom litteratursøk i Oria og Google Scholar ble det funnet annen forskningslitteratur om krysskulturelle barns kollektive ansvarserfaringer. Søkeordene var: barns ansvar, barns ansvarserfaringer, barn og arbeid, parentifisering, krysskulturelle barn, det kommunale barnevernet, arbeid med minoritetsfamilier, identitet og enslige mindreårige flyktninger. Problemstillingen vår er utforskende, og søkeordene reflekterer at det var viktig å få frem nyanser og synspunkter på barns kollektive ansvarserfaringer i ulike kulturelle kontekster. Forskningslitteraturen 
som belyste vårt tema, ble gjennomlest, og informasjon om barns kollektive ansvarserfaringer er benyttet i vår diskusjon.

\section{Empiri og diskusjon}

Først presenteres empiriske funn om barns kollektive ansvarserfaringer i Llaqta samt forskning om barns kollektive ansvarserfaringer i Norge og i land utenfor Europa. Videre diskuteres hvordan økt kunnskap om krysskulturelle barns ansvarserfaringer kan ha betydning for ansatte i kommunalt barnevern som jobber for å sikre barnas beste.

\section{Barns kollektive ansvarserfaringer}

Data fra feltarbeidet i Llaqta viste at barna likte å ta ansvar for familiens og lokalsamfunnets opprettholdelse. Ansvarsoppgavene som barna i Llaqta ivaretok, varierte, men alle måtte bidra til familiens overlevelse. Barna var tidlig klar over betydningen av deres innsats for fellesskapet, deres levekår som fattige bønder tatt i betraktning. Typiske ansvarsoppgaver for barn fra barneskolealder var melking, mating av dyr, ærender, skolearbeid, å hjelpe til med matlaging, oppvask, gjeting, åkerarbeid, arbeid i familiens butikk en time eller to, vask av egne klær, pass av søsken eller å hjelpe besteforeldre. Barna arbeidet ofte sammen med søsken eller andre familiemedlemmer, og de tok gjerne initiativ til å arbeide og hjelpe andre utenom sine faste plikter. I tillegg til skolearbeid hadde barna mulighet til å kombinere ansvarsoppgaver med lek, samt egen tid til lek utenom ansvarsoppgavene.

Deltakelse i arbeidsoppgaver tilpasset alder og modenhet ble av foreldrene i Llaqta ikke betraktet som noe som hadde negative konsekvenser for barna. Foreldre responderte ofte positivt på barnas stadige initiativ til å ville delta i arbeidsoppgaver. Barna ble inkludert som verdige medarbeidere, og de fikk mange positive tilbakemeldinger fra familien og andre i landsbyen når de tok ansvar. Barn som unnlot å ta ansvar, ble straffet for ikke å ha handlet etter normene. Barns rolle i dette samfunnet kan forstås som preget av et moralsk ideal om at «et godt barn arbeider og hjelper til» i tillegg til å gå på skole og leke. Å bli oppfattet som en «trabajador», 
et arbeidsomt, ansvarsfullt, kollektivt orientert menneske, var i stor grad samsvarende med å bli betraktet som et godt menneske i Llaqta.

Annen forskning om barns kollektive ansvarserfaringer viser liknende funn og understøtter dataene fra Llaqta. Aufseeser med flere (2018) redegjør for en rekke studier som viser at barns arbeid og ansvarstaking rundt om i verden kan ha psykososiale fordeler. Arbeid kan noen ganger gi barn mulighet til å ta kontroll over eget liv, det gir håp om å overkomme vanskeligheter og forbedre livssituasjonen, og barn kan få større selvtillit gjennom arbeid (Aufseeser et al., 2018). Crivello, Vennam og Komanduris studie (2012) viste for eksempel at unge arbeidere i rurale India snakket om hvordan det å arbeide gjorde dem stolte, særlig når de kunne bidra til å hjelpe familien. Aufseeser med flere (2018) understreker at mange barn blir ansett som ansvarsfulle og oppnår rettigheter som bidragsytende samfunnsmedlemmer når de hjelper sine familier og samfunnet. Morrow (2017) sammenlikner fire ulike studier utført i Etiopia, India, Peru og Vietnam. Hun viser hvordan arbeid og ansvarsoppgaver innenfor familiens hushold bidrar til å integrere barna i familiesystemene. Ferdigheter lært gjennom arbeid vil også være nyttige hvis barna ikke har mulighet til å fullføre skolen, eller hvis foreldre går bort og barna må klare seg selv $i$ et samfunn uten et fungerende velferdssystem (Morrow, 2017; Høgmo, 2012). Morrow (2017) beskriver hvordan fattige barn i fire ulike land inngikk i gjensidige avhengighetsrelasjoner til sine familier, og barna beskrev ofte arbeid som en kilde til stolthet. De opplevde det som viktig å støtte familien sin, noe som bidro til at de ble oppfattet som «et godt barn» (Morrow, 2017).

En studie om oppdragelsespraksiser blant pakistanske mødre i Oslo viser også hvordan mødrene anså barn og foreldre som gjensidig avhengig av hverandre (Erstad, 2015). Foreldre lærte ikke barna først og fremst å ta ansvar for seg selv, men å ta mer og mer ansvar overfor familien (Erstad, 2015). Lidén (2017) påpeker at også enslige mindreårige flyktninger ofte inngår i kollektivt orienterte familieforpliktelser. Familien, som i en del tilfeller har investert i reisen til Norge, forventer gjerne at barnet skal tilbakebetale sin gjeld, for eksempel i form av penger eller ved å oppnå gode skoleresultater. Mange enslige mindreårige flyktninger er opptatt av å komme fort i arbeid, slik at de kan hjelpe familien sin 
(Paulsen et al., 2020). Samtidig får de ta del i et felleskap med nordmenn og får praktisere norsk. Noen mestrer dette godt og får ekstra krefter av å klare å hjelpe familien, mens andre opplever at de ikke klarer å innfri forventninger fra både familien og det norske majoritetssamfunnet samtidig. Engebrigtsen og Fuglerud (2009) viser i sin studie av tilpasningsprosesser blant somaliske og tamilske ungdommer i Norge at disse ungdommene opplevde at de måtte tilpasse seg det norske samfunnets $\mathrm{krav}$ og forventninger om individuell selvstendighet og frihet.

\section{Nyansert kunnskap til barns beste}

Det er trolig vanskelig, om ikke umulig, for barnevernansatte å utøve en best mulig tjeneste for krysskulturelle barn uten nyansert kunnskap om disse barnas kollektive ansvarserfaringer. Data viser at en del krysskulturelle barn tar mye ansvar for opprettholdelsen av familien. Krysskulturelle barns ansvarstaking overfor familien blir ofte verdsatt og kan være viktig for det enkelte barnet og for samspillet i familiene og samfunnet som helhet. Ifølge Abebe og Bessell (2011) bryter forståelsen av barns kollektive ansvarserfaringer utenfor Europa med den vestlige forståelsen av en ideell barndom. I det norske samfunnet er det for eksempel en utbredt forståelse at barn skal være mottakere av omsorg, ikke omsorgsgivere overfor sine foreldre (Engebrigtsen, 2020). Denne forståelsen av barns rolle kan føre til at krysskulturelle barns ansvarstaking av barnevernansatte betraktes som destruktiv parentifisering, noe som trolig vil ha betydning for hvilke handlinger som settes i gang for å ivareta barnets beste. Destruktiv parentifisering kan føre til omfattende inngripen i barns og familiers liv, noe som kan få alvorlige konsekvenser for barns integrasjon, både i familien og i samfunnet for øvrig. Barns ansvarserfaringer og kollektive orientering i en del samfunn utenfor Europa kan synes å ha likhetstrekk med adaptiv parentifisering. Betraktes kollektiv ansvarstaking som adaptiv parentifisering, vil det trolig frembringe mindre inngripende handlinger for å ivareta barnets beste enn ved destruktiv parentifisering. Hvis barns kollektive ansvarserfaringer anses som adaptiv parentifisering, kan barnevernet være med på å styrke både selvfølelse, empati og barns resiliens (Haugland, 2006). 
En nyansert forståelse om at ikke alle kollektive ansvarserfaringer som krysskulturelle barn har, kan klassifiseres som destruktiv parentifisering, kan trolig også bidra til at barnevernansatte blir mer oppmerksomme og sensitive når de handler for å sikre krysskulturelle barns beste. Tilegnelse av en nyansert forståelse av krysskulturelle barns ansvarstaking med tanke på destruktiv eller adaptiv parentifisering kan derfor bidra med å styrke barnevernansattes kulturkompetanse. Ifølge McPhatter (1997) kan kulturkompetanse teoretisk fremstilles som blant annet det å ha tilstrekkelig kunnskap til å kunne forstå kulturforskjeller. Kulturkompetanse innebærer også at barnevernansatte utvikler evne til å identifisere og reflektere over forhold som har med kultur å gjøre (McPhatter, 1997). Dette innebærer at barnevernansatte søker å få innsyn i ulike kulturelle referanserammer ved å etterspørre barns og unges egne erfaringer, og hva det betyr for dem (Saus, 2006; McPhatter, 1997; Boine, 2010). Målet med kulturkompetanse er ifølge Williams (2005) å sørge for at man unngår en praksis som ikke er sensitiv overfor kulturelle forskjeller, som er respektløs mot dem som er fra en annen kultur, og som er diskriminerende. Med mer nyansert kunnskap om krysskulturelle barns ansvarstaking kan det bli mulig for barnevernansatte å se flere handlingsalternativer for tiltak innenfor sitt handlingsrom. Barnevernansatte kan samtidig få muligheten til å rette oppmerksomheten mot hva som konkret kan gjøres for å sikre barnas beste. Styrket kulturkompetanse kan slik bidra til at barnevernansattes handlingsrom for yrkesutøvelse utvides.

\section{Individuelt versus kollektivt orienterte ansvarserfaringer}

Økt forståelse for krysskulturelle barns kollektive ansvarserfaringer er viktig for å ivareta barnets beste, spesielt når barna erfarer motstridende forventninger knyttet til sin ansvarstaking. Data tyder på at barnevernansatte møter barn med krysskulturell bakgrunn som har en livssituasjon preget av mange og ulike forventninger fra det norske majoritetssamfunnet, fra familie og fra minoritetsmiljøer om hvordan de kan være «et godt barn». Forventningene til barns rolle i det norske samfunnet er ofte individorientert, da oppdragelsens mål ofte er å utvikle autonome 
mennesker som primært ivaretar egne interesser (Jávo, 2010), mens forventningene fra krysskulturelle barns familie og minoritetsmiljø ofte er kollektivt orientert. Det vil si at et barn har forpliktelser overfor slekt og venner som er med i deres nettverk (Jávo, 2010). Individorientering vil si at barna er mer orientert mot seg selv når det gjelder ansvarstaking, mens kollektiv orientering innebærer at barna er opptatt av familiens beste når det gjelder ansvarstaking. I en norsk kontekst kan krysskulturelle barn forventes å handle både individorientert og kollektivt orientert for å ivareta forventinger som rettes mot dem fra ulike aktører i det norske samfunnet og fra familien. Hvis det gjeldende handlingsrommet i barnevernet får som konsekvens at barnevernansatte møter barns ønsker om å ta ansvar for sin familie med individorienterte ansvarsforventninger, og med forståelsen om at det er familien som skal ta ansvar for barnet, og ikke omvendt (Engebrigtsen, 2020), kan hjelpen krysskulturelle barn får, være utilstrekkelig. Forventninger som har utspring i ulike orienteringer, kan oppleves som motstridende for det enkelte barnet, og resultatet kan være en opplevelse av krysspress (Eriksen \& Sajjad, 2020). Ungdom med krysskulturell bakgrunn som forteller om sine erfaringer i barnevernet, sier det slik:

Det er dumt å oppleve at når vi vektlegger verdier fra vår kultur, som for eksempel å ta hensyn til folk i familien, kan noen i barnevernet si at vi må tenke mer på oss selv. Det kan bli mye forvirring og sorg ut av dette. (Forandringsfabrikken, 2013, s. 8)

Kunnskap om - og forståelse av - det krysspresset krysskulturelle barn kan være utsatt for, kan bidra til at ansatte blir oppmerksomme på flere muligheter for handling når de skal støtte barn i utsatte situasjoner. Nyansert kunnskap om barns kollektive ansvarserfaringer kan styrke barnevernansattes kulturkompetanse og åpne opp for kultursensitive løsninger. Disse løsningene kan hjelpe krysskulturelle barn til å finne en balansegang mellom handlinger som på den ene siden er individorientert, og som på den andre siden er kollektivt orientert. En balansegang er viktig, for mange krysskulturelle barn i Norge kan ha et stort ansvar for å ivareta behovene for mat og helsehjelp hos familie som fremdeles bor i utlandet (Berg, Svendsen \& Haraldsvik, 2019). 
Samtidig viser data at barns ansvarstaking ofte belønnes med anerkjennelse, mens manglende ansvarstaking kan være knyttet til negative sanksjoner fra familien. Styrket kulturkompetanse kan bidra til kultursensitive løsninger som kanskje ikke trigger straffemekanismer i familien hvis det vurderes at barnets beste er å dempe barnets ansvarstaking for å frigjøre tid til for eksempel skole, lek og andre fritidsaktiviteter. Barnevernansattes kulturkompetanse er viktig for hvordan krysskulturelle barn og deres familier opplever møtet med norsk barnevern, og for barns integrering $i$ det norske samfunnet. Mangelfull kulturkompetanse om barns ansvarstaking kan føre til at barna blir stående alene med ansvaret, både for å «tenke på seg selv» og for å tenke på sin familie. Engebrigtsen (2011) påpeker for eksempel at ungdommer kan oppleve en form for interessekonflikt mellom støtteapparatet i Norge og eksilmiljø og familienettverk i Norge og andre steder i Europa (Engebrigtsen, 2011).

\section{Kunnskap om krysskulturelle barns identitet og barnevernansattes yrkesutøvelse}

Kunnskap om krysskulturelle barns identitet kan være viktig for barnevernansatte når de søker å ivareta barnas beste. Data viser at for en del krysskulturelle barn er ansvarstaking overfor familien viktig for deres identitetsutvikling. Mange opplever stolthet og føler seg som verdifulle medlemmer i familien, samtidig som de får positive tilbakemeldinger fra både familiemedlemmer og venner. Når barn opplever at de bidrar til familiens overlevelse, blir ansvarstaking ofte en stor del av barnets identitet (Engebrigtsen, 2020). For å kunne bidra til at barn utvikler en positiv identitet, er det viktig å anerkjenne deres erfaringer og kunnskaper (Lauritsen \& Berg, 2019, s. 34). Anerkjennelse av erfaringer og kunnskap om krysskulturelle barns ansvarstaking kan bidra tilå styrke det arbeidet barnevernansatte utfører for barnas identitet. Salole (2018, s. 31) påpeker at «[s]tøtte i krysskulturelle barns identitetsarbeid og hjelp til å forene de motsetningene de lever med, øker deres opplevelse av tilhørighet» (Salole, 2018, s. 31). Ved å anerkjenne den betydningen ansvarstaking overfor familien kan ha for et enkelt barn med krysskulturell bakgrunn, og de utfordringene denne ansvarstakingen eventuelt skaper, kan det åpnes et 
rom for at barnevernansatte kan gå i dialog med barna og deres foreldre på nye måter. Det understrekes i høringsnotatet om forslag til ny barnevernlov (2019, s. 54, lovforslag $\$ 1-9$, s. 381) at det er viktig å undersøke hvilken betydning kulturbakgrunn har for det enkeltes barnets identitet, for slik å kunne vurdere barnets beste. Oppmerksomhet på krysskulturelle barns identitet knyttet til ansvarstaking kan slik være viktig når barnevernansatte utvikler hjelpetiltak for å ivareta barnas beste.

Krysskulturelle barn har, ifølge Eriksen og Sajjad (2020, s. 105), overlappende identiteter. Barna bærer ikke bare identitet knyttet til en gruppe, men har også overlappende identitet knyttet til grupper i samfunnet de nå er en del av. Eriksen og Sajjad (2020, s. 107) forklarer nærmere at en person har en rekke identiteter, og hvilken av dem som til enhver tid aktiveres, avhenger av konteksten. Økt forståelse knyttet til krysskulturelle barns kollektive ansvarserfaringer kan gi barnevernansatte mulighet for identifisere den rette identiteten i rett tid, for å unngå å aktivere dilemmaer som krysskulturelle barn kan oppleve. Barnevernansattes forståelse av krysskulturelle barns overlappende identiteter kan være viktig når det reflekteres over hva som er barnets beste når tiltak utformes og iverksettes.

\section{Oppsummering og avsluttende betraktninger}

I dette kapitlet har vi ved bruk av litteratur belyst hvordan en nyansert forståelse av barns kollektive ansvarserfaringer kan være viktig. I barneverntjenesten skal barn i utsatte livssituasjoner ivaretas på best mulig måte, og litteraturen viser at krysskulturelle barn er godt representert i kategorien utsatte barn som avhenger av hjelpetiltak fra barnevernet (Berg et al., 2017). Vår diskusjon tyder på at det for å ivareta barnets beste kan være viktig at barnevernansatte styrker sin kulturkompetanse og benytter nyansert kunnskap om krysskulturelle barns kollektive ansvarserfaringer. Kollektiv ansvarstaking kan betraktes som destruktiv parentifisering i Norge og i andre europeiske land, men ansvarstakingen vil trolig i enkelte land kunne assosieres med adaptiv parentifisering. Kunnskap om skillet mellom individuell og kollektiv orientering når det gjelder ansvarstaking, samt forholdet mellom kollektiv ansvarstaking og 
identitet, kan også være viktig for barnevernansattes forståelse av krysskulturelle barns situasjon når det skal utredes og iverksettes tiltak for å ivareta et barns beste. Økt kulturkompetanse kan slik utvide handlingsrommet for tjenesteutøvelse. Det er behov for empiriske undersøkelser som tematiserer krysskulturelle barns kollektive ansvarserfaringer og barnevernansattes muligheter og begrensninger for å imøtekomme disse barnas behov for hjelp og støtte.

\section{Referanser}

Abebe, T., Waters, J. \& Skelton, T. (Red.). (2017). Laboring and Learning. Singapore: Springer.

Abebe, T. \& Bessell, S. (2011). Dominant discourses, debates and silences on child labour in Africa and Asia. Third World Quarterly, 32(4), 765-786. https://doi.org/1 $0.1080 / 01436597.2011 .567007$

Andersen, O. J., Moldenæs T. \& Torsteinsen, H. (Red.). (2017). Ledelse og skjønnsutøvelse. Analyse, intuisjon, forhandlinger. Bergen: Fagbokforlaget.

Aufseeser, D., Bourdillon, M., Carothers, R. \& Lecoufle, O. (2018) Children's work and children's wellbeing: Implications for policy. Development Policy Review, 36(2), 241-261. https://onlinelibrary.wiley.com/doi/abs/10.1111/dpr.12215

Barne-, ungdoms- og familiedirektoratet. (2020). Årsrapport 2019. Hentet fra https:// bufdir.no/globalassets/global/nbbf/bufdir/arsrapport_2019_barne_ungdoms_og_ familiedirektoratet_oppslag.pdf

Barne-, ungdoms- og familiedirektoratet. (2019). Barnevernets ansvar og organisering. Hentet fra https://bufdir.no/Barnevern/Fagstotte/Samarbeid_ mellom_helse_og_barnevern/Tilbud_og_tjenester/Barnevernets_organisering/

Barnevernloven. (1992). Lov om barneverntjenester (LOV-1992-07-17-100). Hentet fra https://lovdata.no/dokument/NL/lov/1992-07-17-100

Berg, B., Svendsen, S. \& Haraldsvik, M. (2019). Enslige mindreårige i Stavanger. Tiltak, organisering og samarbeid (Rapport fra NTNU Samfunnsforskning). Hentet fra https://samforsk.no/Sider/Publikasjoner/Enslige-mindre\% $\mathrm{C}_{3} \% \mathrm{~A} 5$ rigei-Stavanger--Tiltak,-oranisering-og-samarbeid.aspx

Berg, B., Paulsen, V., Midjo, T., Haugen, G. M. D., Garvik, M. \& Tøssebro, J. (2017). Myter og realiteter. Innvandreres møter med barnevernet (Rapport fra NTNU Samfunnsforskning). Hentet fra https://samforsk.no/Publikasjoner/2017/ Myter\%20og\%2orealiteter\%20-\%2oendelig.pdf

Boine, E. M. (2010). Kulturorientert praksis - en veileder. Tromsø: Barnevernets utviklingssenter i Nord-Norge. 
Bourdillon, M., Levison, D., Myers, W. \& White, B. (2011). Rights and wrongs of children's work. New Brunswick, NJ: Rutgers University Press.

Crivello, G., Vennam, U. \& Komanduri, A. (2012) «Ridiculed for not having anything»: Children's views on poverty and inequality in rural India. I J. Boyden \& M. Bourdillon (Red.), Childhood poverty: Multidiciplinary approaches (s. 218-236). Basingstoke, England: Palgrave Macmillan.

De forente nasjoner. (1989). FNs konvensjon om barnets rettigheter. Hentet fra https://www.regjeringen.no/no/dokumenter/fns-barnekonvensjon/id88078/

Endringslov til barnevernloven. (2020). Lov om endringer i barnevernloven (samtaleprosess, årlig tilstandsrapportering m.v. (LOV-2020-06-19-74). Hentet fra https://lovdata.no/dokument/LTI/lov/2020-06-19-74

Engebrigtsen A. I. (2020). Omsorg og barn utenfor barndommen. I K. Eide (Red.), Barn på flukt. Psykososialt arbeid med enslige mindreårige flyktninger (2. utg., s. 149-170). Oslo: Gyldendal Akademisk.

Engebrigtsen, A. I. (2017). Marianne Rugkåsa, Signe Ylvisaker og Ketil Eide: Barnevern i et minoritetsperspektiv. Sosialt arbeid med barn og familier. Norsk sosiologisk tidsskrift, 1(4), 338-341. https://doi.org/10.18261/issn.2535-2512-2017-04-07

Engebrigtsen. A. I. (2011). Ali's disappearance: The tension of moving and dwelling in the Norwegian welfare society. Journal of Ethnic and Migration Studies, 37(2), 297-313. https://doi.org/10.1080/1369183X.2010.521324

Engebrigtsen, A. I. \& Fuglerud, Ø. (2009). Kultur og generasjon. Tilpasningsprosesser blant somaliere og tamiler i Norge. Oslo: Universitetsforlaget.

Eriksen, T. H., Sajjad, T. A. (2020). Kulturforskjeller i praksis. Perspektiver på det flerkulturelle Norge (7. utg.). Oslo: Gyldendal Akademisk.

Eriksen, T. H. \& Sajjad, T. A. (2015). Kulturforskjeller i praksis. Perspektiver på det flerkulturelle Norge (6. utg.). Oslo: Gyldendal Akademisk.

Eriksen, T. H. (1998). Små steder - store spørsmål. Innføring i sosialantropologi (2.utg.). Oslo: Universitetsforlaget.

Erstad, I. (2015). Here, now and into the future: Child rearing among NorwegianPakistani mothers in a diverse borough in Oslo, Norway (Doktorgradsavhandling). Universitetet i Oslo, Oslo. https://www.duo.uio.no/bitstream/handle/10852/50187/ Erstad_phd\%2omaterie.pdf? sequence $=1$ \&isAllowed $=\mathrm{y}$

Espedal, B. \& Kvitastein O. A. (2014). Handlingsrom og læring. I R. Rønning, W. Brochs-Haukedal, L. Glasø \& Matthiesen, S. B. (Red.), Livet som leder. Lederundersøkelsen 3.o. Bergen: Fagbokforlaget.

Espedal, B. (2008). Handlingsrom for ledelse. Beta, 22(2), 20-38.

Forandringsfabrikken. (2013). MinoritetsRåd fra unge i barnevernet til myndighetene og barnevernet (Rapport). Hentet fra http://www.forandringsfabrikken.no/article/ forandringsfabrikken.no-article-minoritetsråd 
FN-sambandet. (2019). Barnekonvensjonen. Hentet fra https://www.fn.no/Om-FN/ Avtaler/Menneskerettigheter/Barnekonvensjonen

Fylkesnes, M. K. \& Paulsen, V. (2019) Barnevern og migrasjon: barnevernspedagogen i møte med familier med kort botid i Norge. I I. Studsrød, V. Paulsen, I. Kvaran \& K. Mevik (Red.), Barnevernspedagog. En grunnbok. Oslo: Universitetsforlaget.

Grønvold, E. \& Støre, J. (2010). Miljøarbeid i barnevernet. Systematikk og refleksjon. Oslo: Universitetsforlaget.

Hambrick, D. C. \& Finkelstein, S. (1987). Managerial discretion: A bridge between polar views of organizational outcomes. Research in Organizational Behavior, 9, 369-406.

Hastrup, K. (1995). A passage to anthropolgy. Between experience and theory. London: Routledge.

Haugland, B. S. M. (2006) Barn som omsorgsgivere: Adaptiv versus destruktiv parentifisering. Tidsskrift for norsk psykologforening, 43(3), 211-220. https:// www.researchgate.net/profile/Bente_Haugland/publication/277631511_ Barn_som_omsorgsgivere_Adaptiv_versus_destruktiv_parentifisering/ links/556eeogoo8aeccd7773f8841.pdf

Høgmo, K. (2012). «Jeg liker å arbeide». En studie av barns erfaringer og initiativ som arbeidende bønder og elever $i$ en peruansk fjellandsby (Masteroppgave). Norges teknisk-naturvitenskapelige universitet, Trondheim.

Høstmælingen, N., Kjørholt, E. S. \& Sandberg, K. (2020). Barnekonvensjonen. Barns rettigheter $i$ Norge (4. utg.). Oslo: Universitetsforlaget.

Barne- og likestillingsdepartementet. (2019). Høring - forslag til ny barnevernlov [Høringsnotat]. Hentet fra https://www.regjeringen.no/ contentassets/7a124c63b81b487e9d79ae44b73a2b7o/horingsnotat-nybarnevernslov---april-2019-.pdf

Integrerings- og mangfoldsdirektoratet (IMDI). (2018). Bosetting av enslige mindreårige flyktninger. Hentet fra https://www.imdi.no/planlegging-ogbosetting/slik-bosettes-flyktninger/enslige-mindrearige-flyktninger/

International Labour Office (ILO). (2017). Global estimates of child labour. Results and trends, 2012-2016 (Rapport). Hentet fra https://www.ilo.org/wcmsp5/groups/ public/---dgreports/---dcomm/documents/publication/wcms_575499.pdf James, A., Jenks, C. \& Prout, A. (1999). Den teoretiske barndom. København: Gyldendal.

Jávo, C. (2010). Kulturens betydning for oppdragelse og atferdsproblemer. Oslo: Universitetsforlaget.

Jenkins, R. (2014). Social identity (4. utg.). London: Routledge.

Johansen, J. I, Juell, I. H. \& Lysvold, S. S, (2019, 6. mars). Dette er Norges best betalte ungdomsjobb. nrk.no. Hentet fra https://www.nrk.no/nordland/dette-er-norgesbest-betalte-ungdomsjobb-1.14460719 
Jurkovich, G. J. (1997). The plight of the parentified child. New York: Brunner Mazel. Kvello, Ø. (2015). Barn i risiko. Skadelige omsorgssituasjoner (2.utg.). Oslo: Gyldendal Akademisk.

Lauritsen, K. \& Berg, B. (2019). Familien i eksil - om å finne fotfeste i et nytt land. I K. Kalkman og S. Kibsgaard (Red.), Vente, håpe, leve. Familier på flukt møter norsk hverdagsliv (s. 23-37). Oslo: Universitetsforlaget.

Lidén, H. (2017). Barn og migrasjon. Mobilitet og tilhørighet. Oslo: Universitetsforlaget.

McPhatter, A. R. (1997). Cultural competence in child welfare: What is it? How do we achieve it? What happens without it? Child Welfare, 76(1), 255-278. https:// psycnet.apa.org/record/1997-02207-006

Montgomery, H. (2008). An introduction to childhood. Anthropological perspectives on children's lives. Hoboken, NJ: Wiley-Blackwell.

Morrow, V. (2017) Intersections of school, work, and learning: Children in Ethiopia, India, Peru, and Vietnam. I T. Abebe, J. Waters \& T. Skelton (Red.), Laboring and learning (s. 155-177). Singapore: Springer.

NOU 2009: 22. (2009). Det du gjør, gjør det helt - Bedre samordning av tjenester for utsatte barn og unge. Hentet fra https://www.regjeringen.no

Paulsen, V., Wendelborg, C., Riise, A., Berg, B., Tøssebro, J. \& Caspersen, J. (2020). Ettervern - en god overgang til voksenlivet? Helhetlig oppfølging av ungdom med barnevernerfaring (Rapport fra NTNU Samfunnsforskning). Hentet fra: https:// samforsk.no/Publikasjoner/2020/Ettervern\%2O-\%2oen\%2ogod\%2oovergang\%2O til\%2ovoksenlivet\%2oWEB.pdf

Proff, A., Proff, G., Toresen, G. \& Steinrem, I. (Red). (2018). Barnas barnevern: trygt, nyttig og samarbeidende for barn. Oslo. Universitetsforlaget.

Punch, S. (2003). Childhoods in the majority world: Miniature adults or tribal children? Sociology, 37(2). https://doi.org/10.1177/0038038503037002004

Salole, L. (2018). Identitet og tilhørighet. Om ressurser og dilemmaer i en krysskulturell oppvekst (2.utg.). Oslo: Gyldendal Akademisk.

Saus, M., Salamonsen, A., Douglas, M., Hansen, K. L. \& Thode, S. K. (2018). Utredning om barnevern for den samiske befolkningen, innvandrere og nasjonale minoriteter i Norge. Kompetansehevende tiltak, kunnskapsmiljø og samiske barns særlige rettigheter (Rapport 2 2018). Hentet fra https://bufdir.no/nn/ Bibliotek/Dokumentside/?docId=BUFoooo4500

Saus, M. (2006). Metoder for barnevernet i samiske områder (Hefte 5, Kultur og barnevernsarbeid). Tromsø: Barnevernets utviklingssenter i Nord-Norge. Hentet fra https://uit.no/Content/233094/Hefte\%205,\%20Metoder\%2ofor\%2O barnevernet\%2oi\%2osamiske\%20omr\%E5der,\%2oSaus\%202006.pdf Schrumpf, E. (2007). Barndomshistorie. Oslo: Samlaget. 
Schönfelder, W., Andersen, S. T. \& Kane, A. A. (2018). Handlingsrom i barnevernet. I W. Schönfelder, W., S. T. Andersen \& A. A. Kane (Red), Handlingsrom i barnevernet. Muligheter og begrensninger for profesjonsutøveren (s. 13-16). Bergen: Fagbokforlaget.

Skivenes, M. (2018). Barneperspektiv i fokus. I A. Proff., G. Proff, G. Toresen \& I. Steinrem, I. (Red). Barnas barnevern: trygt, nyttig og samarbeidende for barn (s. 12-17). Oslo: Universitetsforlaget.

Statistisk sentralbyrå. (2020). Færre fekk tiltak fra barnevernet. Hentet fra https:// www.ssb.no/sosiale-forhold-og-kriminalitet/artikler-og-publikasjoner/faerrefekk-tiltak-fra-barnevernet

Stewart, R. (1982). A model for understanding managerial jobs and behavior. Academy of Management Review, 7(1), 7-13.

Strand, T. (2007). Ledelse, organisasjon og kultur (2. utg.). Bergen: Fagbokforlaget. Ulvik, O. S. (2019). Barn, hverdagsliv og sosial deltakelse - tenkeredskaper fra en sosiokulturell tradisjon. I I. Studsrød, V. Paulsen, I. Kvaran \& K. Mevik (Red.), Barnevernspedagog. En grunnbok (s. 119-133). Oslo: Universitetsforlaget

Williams, C. C. (2005). Training for cultural competence. Journal of Ethnic \& Cultural Diversity in Social Work, 14(1-2), 111-143. 


\section{Forfatteromtaler}

Bente Lilljan Lind Kassah er professor i sosiologi og er ansatt ved barnevernspedagogutdanningen ved UiT Norges arktiske universitet i Harstad. Hun har følgende fordypningsområder: arbeidsliv og informasjonsteknologi, funksjonshemming og deltakelse, samhandling i helse- og omsorgstjenesten og barnevern. Kassah har utgitt en fagbok og har vært medredaktør i fire vitenskapelige antologier. Hun har en rekke publikasjoner i både nasjonale og internasjonale tidsskrifter.

Hilde Nordahl-Pedersen er amanuensis ved UiT Norges arktiske universitet, Handelshøyskolen i Harstad. Hun er samfunnsviter og har hatt flere lederverv i høyere utdanningsinstitusjon. Hun har ledet en rekke innovasjons- og utviklingsprosjekter nasjonalt og internasjonalt. NordahlPedersen har en rekke norske publikasjoner og er medredaktør i flere vitenskapelige antologier.

Wivi-Ann Tingvoll er dosent emerita ved sykepleierutdanningen ved UiT Norges arktiske universitet i Narvik. Hun er utdannet sykepleier og har mastergrad i folkehelsevitenskap. Tingvoll er medredaktør i vitenskapelige antologier og har en rekke internasjonale og nasjonale publikasjoner.

Sven-Tore Dreyer Fredriksen er førsteamanuensis ved UiT Norges arktiske universitet på Institutt for helse- og omsorgsfag. Han har erfaring fra kirurgisk og intensivavdeling samt sykehjem. Han har vært tilsatt ved høgskoler og universiteter med oppgaver knyttet til undervisning og veiledning på bachelor-, master- og doktorgradsnivå. Dreyer Fredriksen er redaktør og forfatter i en vitenskapelig antologi i intensivsykepleie samt forfatter i tre vitenskapelige antologier innenfor omsorg i kommunehelsetjenesten og sykepleiepraksis. Han har flere publiserte vitenskapelige artikler i internasjonale, nordiske og norske forskningstidsskrifter. 
Lena Wiklund Gustin er dosent i omsorgsvitenskap ved Mälardalens högskola i Sverige og professor ved sykepleieutdanningen ved UiT Norges arktiske universitet i Narvik. Hun er sykepleier med spesialisering innen psykiatrisk sykepleie og psykoterapi og har doktorgrad i temaet helsevitenskap. Hennes forskning er rettet mot helse, psykiatrisk omsorg, sykepleiestudenters integrasjon av teori og praksis samt metodeutvikling innenfor narrativ hermeneutikk.

Margrethe Amalie Tresselt er universitetslektor ved UiT Norges arktiske universitet. Hun har tidligere jobbet som mellomleder og lærer ved en barneskole, og hun underviser nå ved Institutt for barnevern og sosialt arbeid. Hun interesserer seg særskilt for tverrfaglig og tverrprofesjonelt samarbeid, både internt i og mellom etater som jobber for barns beste. Hun har flere nasjonale publikasjoner.

Grethe M. Borgerød er barnevernspedagog og studieleder ved Institutt for barnevern og sosialt arbeid ved UiT Norges arktiske universitet. Hennes interessefelt omhandler hovedsakelig kommunalt barnevern, ungdom og psykisk helse, inkludering og deltakelse samt samspill og samvær mellom barn og foreldre. Hun har flere nasjonale publikasjoner.

Bodil S. Olsvik er stipendiat ved Institutt for barnevern og sosialt arbeid ved UiT Norges arktiske universitet. Hun har hovedfag i pedagogikk og har mange års erfaring som leder innen høyere utdanning og i barnevernet. Hennes forskningsinteresser er ledelse og bruk av skjønn i ledelse samt profesjon og ledelse.

Karin Ravn Pedersen er utdannet sykepleier og er førstelektor og praksiskoordinator ved UiT Norges arktiske universitet i Narvik. Hun har en master i helsefag fra UiT, og hennes interesseområder er sykepleie i den kommunale helse- og omsorgstjenesten, studenterfaringer i praksis og utvikling av sykepleiefaglig kompetanse. Hun har publisert flere vitenskapelige artikler i tidsskrifter og bøker.

Sari Lindgren er universitetslektor ved sykepleierutdanningen ved UiT Norges arktiske universitet, studiested Narvik. Hun er intensivsykepleier 
og har mastergrad i helsefag. Hennes forskningsinteresser er pasienterfaringer med å leve med kols, omsorg innen kommunehelsetjenesten, pasientsikkerhet samt simulering som pedagogisk metode innen helsefag.

Mona Lahm Høgbakk er universitetslektor ved sykepleierutdanningen ved UiT Norges arktiske universitet, studiested Narvik. Hun har en master i avansert klinisk sykepleie og har lang erfaring som intensivsykepleier. Hennes forskningsområder er rettet mot organisering i helsetjenesten, omsorg i kommunehelsetjenesten og simulering som pedagogisk metode i helsefag.

Anne Svelstad Evju er førstelektor ved bachelorstudiet i sykepleie ved UiT Norges arktiske universitet i Narvik. Hun er utdannet sykepleier og helsesykepleier og har en master i klinisk sykepleie. Evjus interessefelt er helsefremmende og forebyggende sykepleie samt prosjekter som retter seg mot pedagogiske metoder i sykepleieutdanningen. Hun har publisert bokkapitler og vitenskapelige artikler i nasjonale og internasjonale tidsskrifter.

Synnøve Vestly er tidligere førstelektor ved UiT Norges arktiske universitet ved sykepleieutdanningen i Harstad. Hennes forskningsområder er intensivsykepleie, klinisk sykepleie og praksisveiledning. Vestly har flere nasjonale publikasjoner.

Linda M. Løvdal er ansatt som avdelingssykepleier ved Gratangsheimen i Gratangen kommune og er tidligere universitetslektor ved UiT Norges arktiske universitet ved sykepleierutdanningen i Harstad. Hun har lang undervisningserfaring innenfor grunnleggende sykepleie og veiledning.

Randi Nymo er pensjonert førsteamanuensis (ph.d.) ved UiT Norges arktiske universitet i Narvik. Hun har hovedfag i sykepleievitenskap og doktorgrad i helse- og omsorgsfag i 2011, begge fra UiT. Nymos forskning er i hovedsak viet til møter mellom den samiske pasienten og helsevesenet, samt til hvordan forståelseshorisonter skaper helseomsorgssystemer. Hun har deltatt med presentasjoner på flere internasjonale kongresser og har publisert både nasjonalt og internasjonalt. 
Katrine Høgmo er stipendiat ved Institutt for vernepleie ved UiT Norges arktiske universitet i Harstad. Hun har mastergrad i sosialantropologi og har erfaring fra barne- og familietjenesten i Trondheim samt som universitetslektor ved Institutt for barnevern og sosialt arbeid ved UiT. Hennes forskningsinteresser er knyttet til barns rolle og deltakelse i ulike samfunn, urfolk og arbeidsinkludering av personer med utviklingshemming.

Kwesi Alexander Kassah er professor i sosiologi ved Institutt for vernepleie ved UiT Norges arktiske universitetet. Kassah forsker innenfor temaet funksjonshemming og deltakelse, har utgitt flere bøker og har publisert i nasjonale og internasjonale tidsskrifter. Han er fast medlem i redaktørrådet for det internasjonale tidsskriftet Disability and Rehabilitation i England. 